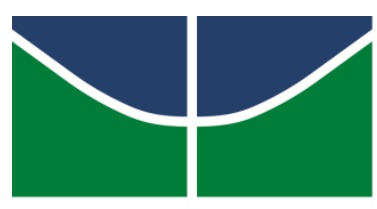

UNIVERSIDADE DE BRASÍLIA - UnB

FACULDADE DE EDUCAÇÃO PROGRAMA DE PÓS-GRADUAÇÃO EM EDUCAÇÃO

A CONSTRUÇÃO COLETIVA DE UMA PRÁXIS EMANCIPATÓRIA EM ALFABETIZAÇÃO MATEMÁTICA

ANA MARIA PORTO NASCIMENTO

BRASÍLIA-DF

2016 


\section{A CONSTRUÇÃO COLETIVA DE UMA PRÁXIS EMANCIPATÓRIA EM ALFABETIZAÇÃO MATEMÁTICA}

Tese apresentada ao Programa de PósGraduação em Educação da Universidade de Brasília - UnB, como requisito parcial para a obtenção do título de Doutora em Educação, na área de confluência Ensino de Ciências e Matemática, sob a orientação do Professor Doutor Cristiano Alberto Muniz.

\section{BRASÍLIA-DF}




\section{ANA MARIA PORTO NASCIMENTO}

\section{A CONSTRUÇÃO COLETIVA DE UMA PRÁXIS EMANCIPATÓRIA EM ALFABETIZAÇÃO MATEMÁTICA}

Tese apresentada ao Programa de Pós-Graduação em Educação da Universidade de Brasília UnB, como requisito parcial para a obtenção do título de Doutora em Educação, na área de confluência Ensino de Ciências e Matemática.

Brasília, 12 de dezembro de 2016.

Orientador:

Professor Doutor Cristiano Alberto Muniz Banca Examinadora

Professora Doutora Carmen Lucia Brancaglion Passos (UFSCar)

Professora Doutora Regina da Silva Pina Neves (MAT/UnB)

Professora Doutora Kátia Curado Pinheiro Silva (FE/UnB)

Professor Doutor Cleyton Hércules Gontijo (FE/UnB) 
Dedico este trabalho às profissionais participantes desta pesquisa 


\title{
AGRADECIMENTOS
}

\author{
A DEUS; \\ a TODA minha família; \\ ao meu orientador professor Dr. CRISTIANO MUNIZ; \\ às ALFABETIZADORAS, às COORDENADORAS, à GESTORA e às CRIANÇAS que \\ atuam na escola em que foi realizada esta pesquisa; \\ enfim, a TODOS os meus amigos e minhas amigas que me ajudaram a concluir esta etapa de \\ vida, \\ os meus SINCEROS AGRADECIMENTOS.
}


O correr da vida embrulha tudo. A vida é assim: esquenta e esfria, aperta e daí afrouxa, sossega e depois desinquieta. O que ela quer da gente é CORAGEM.

(Guimarães Rosa) 


\section{LISTA DE FIGURAS}

Figura 1 - Extrato da sequência de atividades .................................................................. 100

Figura 2 - Previsão de conteúdos e objetivos para a terceira semana .................................. 101

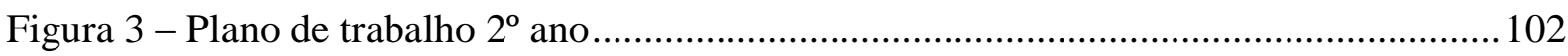

Figura 4 - Atividades previstas para a aula ................................................................... 105

Figura 5 - Parte da sequência preparada para o $3^{\circ}$ ano ..................................................... 182

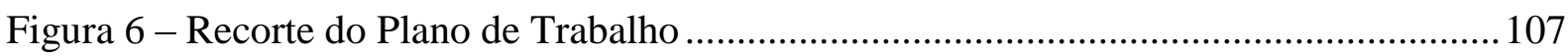

Figura 7 - Recorte do Plano de Trabalho para o $2^{\circ}$ ano maio 2015 ...................................... 108

Figura 8 - A atividade de nomear cada objeto contado ..................................................... 109

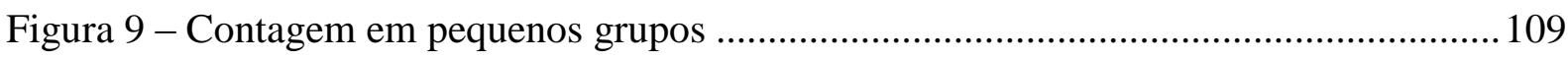

Figura 10 - Atividade elaborada pelas professoras do $3^{\circ}$ ano ........................................... 110

Figura 11 - Resolvendo operações e mobilizando conceitos no Jogo Forme 10 ...................118

Figura 12 - Jogo do 2 em grupo e registro nas fichas ........................................................ 119

Figura 13 - Proposição de perguntas referentes ao conteúdo matemático na realização da

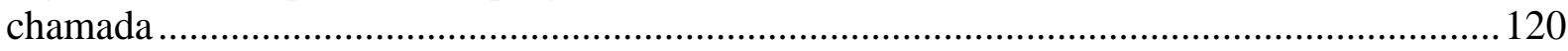

Figura 14 - Recorte do Plano de Trabalho/ operação de multiplicação .................................. 121

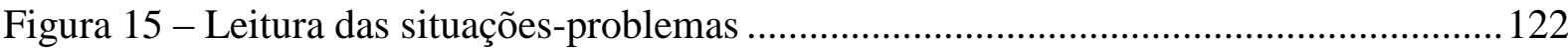

Figura 16 - Manipulação de materiais para resolver a divisão ............................................. 123

Figura 17 - O processo de contar o total, distribuir e contar com quantos palitos cada prato ficou 123

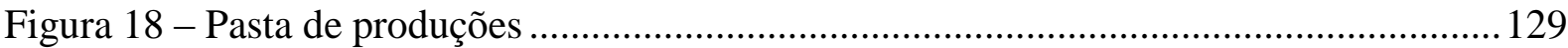

Figura 19 - Inserção de perguntas no plano de trabalho ...................................................... 130

Figura 20 - Atividade elaborada pelas professoras ........................................................... 132

Figura 21 - Um resumo da história A economia de Maria .................................................. 134

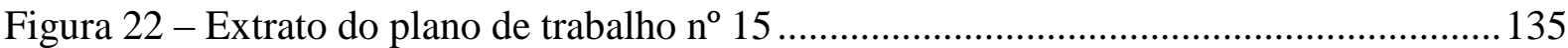

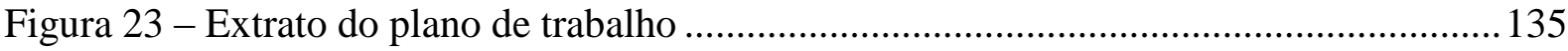

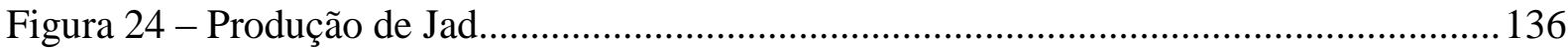

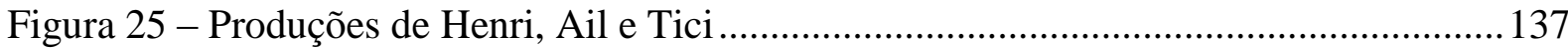

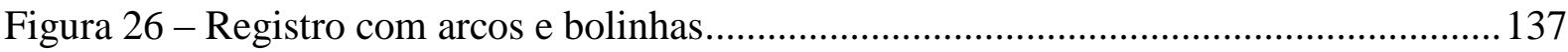

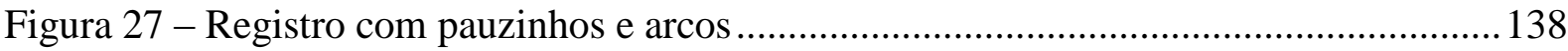

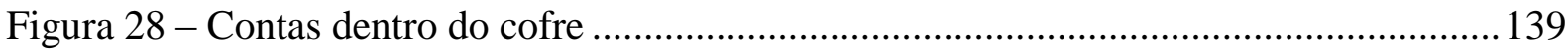

Figura 29 - Recorte do plano de trabalho do $3^{\circ}$ ano ........................................................... 140

Figura 30 - Situações-problema com o contexto de Branca de Neve ................................... 140 
Figura 31 - Registro de produção das crianças

Figura 32 -Registro de atividade de uma criança

Figura 33 -Exemplo de produção.

Figura 34 - Livro paradidático explorado pelas alfabetizadoras

Figura 35 - Registro das operações de adição

Figura 36 - Registro das operações de multiplicação

Figura 37 - Dinâmica entre a ação, a produção de conhecimentos, os questionamentos e os estudos

Figura 38 - Extrato do diário de campo 24 julho

Figura 39 - Fatores que dificultavam a ação

Figura 40 - Parte do texto produzido pelas coordenadoras e pela pesquisadora 164

Figura 41 - Adaptação do Jogo do Forme 10. 166

Figura 42 - Anotações sobre como encaminhar o trabalho 167

Figura 43 - Sequencia das anotações sobre o trabalho a desenvolver 167

Figura 44 - Cartaz com o registro dos grupos de 10 formados pelos grupos. 167

Figura 45 - Reflexão sobre as atividades a serem desenvolvidas em sala 168

Figura 46 - Exemplo de plano de trabalho. 168

Figura 47 - Quadro de resultados da avaliação diagnóstica. 174

Figura 48 - Quarto item da avaliação 175

Figura 49 - Avaliação do segundo ano: sétimo item. 177

Figura 50 - Avaliação do terceiro ano: sétimo item 178

Figura 51 - Imbricação do diálogo entre teoria e prática, ampliação de conhecimentos e reorganização do trabalho pedagógico

Figura 52 - Sequencia didática para o $2^{\circ}$ ano 188

Figura 53 - Registro das operações 197

Figura 54 - Registro da segunda criança. 


\section{LISTA DE QUADROS}

Quadro 1 - Formação e tempo de atuação das participantes.................................................. 80

Quadro 2 - Dinâmica de observação discussão, registro das informações ............................. 82

Quadro 3 - Primeira tentativa de definição das categorias de análise.................................... 95

Quadro 4 -Categorias e subcategorias de análise..................................................................97

Quadro 5 - Organização de conteúdos/ junho de 2015 ........................................................ 183

Quadro 6 - Organização dos conteúdos/ início de maio de 2016 ....................................... 184

Quadro 7 - Descrição da aula realizada no segundo ano .................................................... 169

Quadro 8 - Continuação das atividades com o segundo ano ............................................. 171

Quadro 9 - Descrição da aula no segundo ano - continuação .............................................. 172

Quadro 10 - Continuação das atividades com o segundo ano ............................................ 172

Quadro 11 - Descrição da aula do segundo ano profa. Ira ..................................................... 190

Quadro 12 - Continuação da aula do segundo ano - profa. Ira .......................................... 174

Quadro 13 - Registro no quadro pela criança ................................................................ 191

Quadro 14 - Registro dos diálogos entre professora e crianças ............................................ 191

Quadro 15 - A professora convida a criança a expor o seu pensamento ............................... 192

Quadro 16 - A professora continua a instigar as crianças ................................................. 192

Quadro 17 - Acervo sobre educação matemática pertencente à escola ................................. 193

Quadro 18 - Transcrição do diálogo entre a professora e a pesquisadora ............................ 194

Quadro 19 - Transcrição do vídeo 18 de setembro de 2015 ............................................... 194

Quadro 20 - Transcrição do vídeo: apresentação das professoras ......................................... 195 


\section{LISTA DE SIGLAS}

ANPED Associação Nacional de Pós-Graduação e Pesquisa em Educação

CRAS Centro de Referência em Ação Social

EEMAI Encontro de Educação Matemática nos Anos Iniciais

ENEM Encontro Nacional de Educação Matemática

GEPEMEC Grupo de Pesquisa em Educação Matemática, Estatística e Ciências

IBGE Instituto Brasileiro de Geografia e Estatística

INEP Instituto Nacional de Estudos e Pesquisas Anísio Teixeira

MEC Ministério da Educação

OCDE Organização para Cooperação e Desenvolvimento Econômico

PCN Parâmetros Curriculares Nacionais

PIBID Programa Institucional de Bolsa de Iniciação à Docência

PNAIC Pacto Nacional pela Alfabetização na Idade Certa

PNLD Plano Nacional do Livro Didático

SAEB Sistema de Avaliação da Educação Básica

SBEM Sociedade Brasileira de Educação Matemática

SIPEM Seminário Internacional de Pesquisa em Educação Matemática 


\section{RESUMO}

Este trabalho teve como objetivos analisar o processo de construção de práxis pedagógicas quando as professoras participam, no contexto da escola, de estudos, reflexões e problematizações sobre alfabetização em matemática, e investigar como essas práxis se integram à formação continuada dessas professoras. A pesquisa iniciou-se a partir de inquietações em relação: aos resultados das avaliações em larga escala sobre a alfabetização em matemática; ao desejo de melhor compreender a complexidade do processo de alfabetização; à crença no potencial de aprendizagem da criança e às evidências de que o professor produz conhecimentos sobre o ensinar em diferentes espaços de trabalho, principalmente quando participa de espaços coletivos de reflexão e problematização de sua prática. $\mathrm{O}$ foco foi a práxis em alfabetização matemática e o suporte teórico adotado foram os referenciais em Educação Matemática que discutem a matemática nos anos iniciais, a alfabetização em matemática, o conceito de práxis e de práxis em alfabetização matemática, a relação do professor com o saber, a formação do professor que ensina matemática nos anos iniciais, principalmente a formação da professora alfabetizadora. A questão que norteou esta investigação foi: de que forma a constituição, no contexto da escola, de um espaço de reflexão, problematização, estudo e discussão sobre a prática em Alfabetização Matemática, contribui para a produção de conhecimentos pelas professoras sobre o ensinar e o aprender, de modo a construir novas práxis pedagógicas, e como essas novas práxis integram-se ao processo de formação continuada em serviço da professora alfabetizadora? Adotou-se a perspectiva qualitativa e como referencial metodológico a pesquisa-formação como possibilidade transformação e formação. Para a construção das informações, durante um ano, a pesquisadora permaneceu em uma escola pública municipal de ensino com um grupo de 11 professoras; e utilizou a observação e o grupo de discussão gravados em áudio e vídeo e a análise dos documentos produzidos pelo grupo - os planos de trabalho. A dinâmica da pesquisa-formação contribuiu para a elaboração e o desenvolvimento de sequências de ensino que promoveram aprendizagens em matemática. Defendeu-se a tese, comprovada com a pesquisa, de que A constituição de um espaço de problematização, reflexão, estudo e discussão sobre as práxis em Alfabetização Matemática configura-se como formação continuada em serviço das alfabetizadoras. A relação dinâmica entre teoria e prática, neste espaço, dentro da escola, contribui para a produção de conhecimentos sobre a matemática, seu ensino e sua aprendizagem que se traduzem em diferenciadas práxis em alfabetização matemática que podem constituir-se em práticas emancipatórias, principalmente quando se consideram os aspectos ideológicos, históricos, culturais e políticos em que uma escola, com seu grupo de trabalho tem suas ações implicadas pelos determinantes da regulação estrutural do sistema de ensino. A análise das informações evidenciou que a permanência da pesquisadora na escola e a discussão coletiva sobre a prática em alfabetização matemática constituiu um espaço de trabalho em que foram produzidos conhecimentos sobre matemática, seu ensino e sua aprendizagem. Esses conhecimentos foram integrados à formação continuada das alfabetizadoras, alimentaram a prática e, em um movimento de ação-reflexãotransformação e num contínuo processo de formação, construíram uma postura autônoma das professoras alfabetizadoras e transformaram a prática em uma práxis emancipatória em alfabetização matemática. As informações produzidas indicam uma possibilidade de formação continuada e de parceria entre a universidade e a escola.

Palavras-chave: Alfabetização matemática. Práxis em alfabetização matemática. Formação continuada da alfabetizadora. 


\begin{abstract}
This study aimed at analyzing the process of building pedagogical praxis when teachers, within the school context, engage in studies, reflections and questionings about literacy in mathematics. It also aimed at investigating how these praxes are part of the continued training of those teachers. We started with some concerns related to the results of large scale examinations on literacy in mathematics; the desire to better understand the complexity of the literacy process; the belief in the learning potential of the child and the evidence that the teacher produces knowledge about teaching in different work spaces, especially when he takes part in spaces for reflection and discussion of his practice. We focused on the praxis in mathematical literacy and used as theoretical support frameworks in mathematics education which discuss the mathematics in the early school years, literacy in mathematics, the concept of praxis and of praxis in mathematical literacy, the relationship between the teacher and knowledge, the education of the teacher who teaches mathematics in the early school years, mainly the education of the literacy teacher. The study was guided by the questions: in the context of the school, how does the constitution of a space for reflection, questioning, study and discussion about the mathematical literacy practice contributes to the production of knowledge by teachers on teaching and learning, in order to build new pedagogical praxis; and how these new practices are integrated into the process of continued education of the literacy teacher? We defend in this doctoral degree dissertation, supported by our research, that the constitution of an area of questioning, reflection, study and discussion about praxis on mathematics literacy, sets itself as continued education of literacy teachers in service. Moreover the dynamic relationship between theory and practice, in this space, within the school context, contributes to the production of knowledge about mathematics, their teaching and learning translated into new practices in mathematics literacy. We have adopted a qualitative perspective and as our methodological framework research-training as a possibility for intervention, transformation and training. For the construction of the information we stayed in a public school during a year with a group of 11 teachers. We used observation and the discussion group was audio and video recorded. We also analyzed the documents produced but the group, work plans. The dynamics of the research-training has contributed to the preparation and development of sequences of teaching which promoted learning in mathematics. Defended the thesis, proven with the research that the constitution of a space of problematization, reflection, study and discussion about the praxis in mathematical literacy is configured as a continuous training in the service of literacy teachers. The dynamic relationship between theory and practice, in this space, inside the school, it contributes to the production of knowledge about mathematics, its teaching and its learning that translate into differentiated praxis in mathematical literacy that can constitute in emancipatory practices, especially when it is considered the ideological, historical, cultural and political aspects in which a school, with its work group has its actions implied by the determinants of the structural regulation of the education system. The analysis of these pieces of information showed that the permanence of the researcher in the school, and the collective discussion about the practice in mathematical literacy constituted a working space in knowledge about mathematics was produced. This knowledge was integrated into the continued education of literacy teachers, fostered their practice and, in a movement of action-reflectiontransformation and in a continuous process of education, they built a standalone stance of literacy teachers. These teachers have transformed their practice in an emancipatory praxis in mathematical literacy. The information were produced indicated a possibility of continued education and partnership between university and school.
\end{abstract}

Key words: Mathematical literacy. Praxis in mathematical literacy. Continued education of literacy teacher. 


\section{SUMÁRIO}

INTRODUÇÃO............................................................................................. 15

1 A MATEMÁTICA, A ALFABETIZAÇÃO E A FORMAÇÃO DA ALFABETIZADORA: ALGUNS PRESSUPOSTOS TEÓRICOS.............. 30

1.1 A MATEMÁTICA NOS ANOS INICIAIS DO ENSINO FUNDAMENTAL.. 30

1.1 ALFABETIZAÇÃO MATEMÁTICA.......................................................... 34

1.3 ENSINAR MATEMÁTICA NA ALFABETIZAÇÃO: A RELAÇÃO DO PROFESSOR COM O SABER ………………………................................... 39

1.4 PRÁXIS EM ALFABETIZAÇÃO MATEMÁTICA: A CONSTITUIÇÃO DE UMA PRÁXIS EMANCIPATÓRIA.......................................................... 43

1.4.1 Discussão sobre o conceito de práxis sob a perspectiva de Vasquez........... 43

1.4.2. A constituição de uma práxis pedagógica em alfabetização matemática.... 47

1.4.3 Uma práxis emancipatória em alfabetização matemática............................... 49

1.5. FORMAÇÃO DE PROFESSORES................................................................ 52

1.5.1. Indicativos gerais sobre a formação de professores.......................................... 55

1.5.2 Formação de professores que ensinam matemática........................................... 61

1.5.3 Formação da professora alfabetizadora em matemática.................................. 69

2 A CONSTITUIÇÃO DE UM TEMPO E ESPAÇO DE PESQUISA FORMAÇÃO: PERCURSO METODOLÓGICO....................................... 76

2.1 PESQUISA - FORMAÇÃO: POSSIBILIDADES DE FORMAÇÃO EM UM TRABALHO COLETIVO................................................................................ 77

2.2 CENÁRIO DA PESQUISA: O LOCAL E O GRUPO DE TRABALHO......... 80

2.3 DESCRIÇÃO DO ESPAÇO E DAS AÇÕES DE PESQUISA........................... 81

2.3.1 A elaboração dos planos de trabalho.............................................................. 85

2.3.2 Aulas de Matemática............................................................................................. 90

2.3.3 Encontros de formação em Alfabetização Matemática................................... 91

2.4 EMERSÃO DAS CATEGORIAS DE ANÁLISE............................................. 92 
3 O CONCEITO DE ALFABETIZAÇÃO MATEMÁTICA COMO NORTEADOR DA PRÁTICA PEDAGÓGICA............................................... 99

3.1 AS SITUAÇÕES DE CONTAGEM - APRENDER E ENSINAR O CONCEITO DE NÚMERO NA ALFABETIZAÇÃO.................................... 100

3.2 DA COMPREENSÃO DO SISTEMA DE NUMERAÇÃO DECIMAL ÀS OPERAÇÕES ARITMÉTICAS.

3.3 LER E PROBLEMATIZAR AS ATIVIDADES DOS LIVROS DIDÁTICOS E HISTÓRIAS DOS PARADIDÁTICOS.

3.3.1 Ler e problematizar os problemas dos livros didáticos

3.3.2 Os paradidáticos de Literatura Infantil: contextos para aprender matemática.

4 A RELAÇÃO ENTRE A FORMAÇÃO CONTINUADA EM SERVIÇO NA ESCOLA E AS MUDANÇAS NA PRÁTICA EM ALFABETIZAÇÃO MATEMÁTICA

4.1 AS APRENDIZAGENS, O ABANDONO DE VELHAS CRENÇAS E A ADOÇÃO DE NOVAS CONCEPÇÕES.

4.2 A AMPLIAÇÃO DO CONCEITO DE ALFABETIZAÇÃO

MATEMÁTICA, O DIÁLOGO TEORIA - PRÁTICA E REORGANIZAÇÃO DO TRABALHO PEDAGÓGICO.

4.2.1 A reorganização do trabalho pedagógico

4.2.2 A avaliação diagnóstica e o aprender sobre o ensinar.

4.2.3 A formação continuada e as mudanças na organização curricular.

4.3 A CONSTRUÇÃO DA AUTONOMIA INTELECTUAL: DA PRÁTICA A PRÁXIS.

4.3.1 As aulas: espaço/ tempo de unificar teoria e prática.

4.3.2 A leitura na formação das professoras: um encontro literário em educação matemática

CONSIDERAÇÕES 


\section{INTRODUÇÃO}

Neste texto, apresenta-se uma pesquisa de natureza qualitativa que teve como objetivos analisar um processo de construção de práxis pedagógicas, realizado pelas professoras ${ }^{1}$ alfabetizadoras - sujeitos da pesquisa - quando elas participam, no contexto da escola de estudos, de reflexões, problematizações e discussões sobre alfabetização em matemática e investigar como essas práxis se integram à formação continuada das professoras alfabetizadoras.

Na presente introdução, trazemos alguns elementos da história pessoal da pesquisadora que a levaram a se aproximar da área de educação matemática e da formação de professores. Na sequência, apresentamos a questão de pesquisa, os objetivos e a tese defendida neste trabalho.

Aproximação com a área de educação matemática e a formação de professores ${ }^{2}$

Em minhas experiências com a aprendizagem e o ensino de matemática, vivenciadas tanto na formação inicial quanto na formação continuada, foi configurado o meu interesse por melhor compreender o processo de alfabetização. A relação com o ensino de Matemática começou quando, ainda nos anos iniciais do ensino regular, era convocada para ensinar aos que apresentavam dificuldades em aprender. Durante o Ensino Médio, já manifestava uma preocupação ao observar a ansiedade de alguns colegas em relação à aprendizagem da Álgebra e da Geometria. A escolha por um Curso de Licenciatura nessa área resultou da necessidade de saber mais sobre essa disciplina, que representa para alguns um espaço de desafios e descobertas e para outros traz lembranças negativas.

Durante o curso de Ciências: habilitação em Matemática - no Centro de Ensino Unificado do Distrito Federal, pude iniciar os primeiros estudos sobre problemas de aprendizagem em Matemática, que foram motivados pela percepção das dificuldades de alguns colegas em acompanhar disciplinas como Cálculo e Análise. Foram formados grupos de estudos para que houvesse maior entendimento dos conteúdos. Cada membro do grupo era responsável pelo estudo de um tópico que deveria ensinar aos colegas. Nos momentos de estudo, emergiam sempre questões, como: Porque alguns aprendem mais que os outros? Como explicar que algumas vezes entende-se o conteúdo e em outras vezes tem-se a impressão de estar diante de algo nunca visto e impossível de ser aprendido?

\footnotetext{
${ }^{1}$ Usaremos o termo professoras alfabetizadoras para nos referirmos aos sujeitos desta pesquisa.

${ }^{2}$ Esse primeiro tópico é escrito em primeira pessoa do singular por referir-se à história pessoal da pesquisadora que foi determinante para suas escolhas durante a realização desta pesquisa.
} 
A minha preocupação com o aprendizado de Matemática se tornou ainda maior quando, em dezembro de 1981, fui aprovada no Concurso Público para o Magistério do Ensino Fundamental da rede pública de ensino do Distrito Federal. Em março de 1982, iniciei a carreira no Magistério e, durante todo o período de Faculdade, pude vivenciar experiências como professora em classes dos anos iniciais do Ensino Fundamental. Após o termino do Curso, passei para a regência em classes dos anos finais do Ensino Fundamental e Ensino Médio, tanto no Curso Básico (Científico) quanto no Magistério (Curso Normal).

Esse foi um período de grande aprendizado, devido à convivência que tive com as dificuldades dos alunos, do ensino Fundamental e Médio, em lidar com os problemas matemáticos. Inicialmente, busquei métodos de ensino mais eficientes que contribuíssem para a superação do medo e da ansiedade em relação a essa disciplina. O meu desejo de desenvolver pesquisas nessa área começou a se configurar.

As circunstâncias de vida provocaram o meu retorno à cidade de origem. Ao se aposentarem da Fundação Educacional do Distrito Federal - FEDF, meus pais influenciaram quase toda a família a retornar a Barreiras. Assim, após sete anos de trabalho na FEDF, retornei a Barreiras, e em 1990, ingressei no Magistério Superior na Universidade do Estado da Bahia - Campus IX.

No início dessa nova fase, houve a oportunidade de contar com grandes mestres, os professores veteranos do Curso de Licenciatura em Pedagogia que me auxiliaram nas leituras em Filosofia, Psicologia, Sociologia e História da Educação. Isso foi fundamental para o desenvolvimento de meu trabalho com a disciplina Fundamentos e Metodologia da Matemática, que exigia estudos em Psicologia Cognitiva, Filosofia da Matemática, História da Matemática e, principalmente, Didática da Matemática.

Depois da inteiração com os conteúdos da disciplina Fundamentos e Metodologia da Matemática, era preciso aprofundar estudos nessa área. E, em 1991, pude ingressar no curso de PósGraduação em Metodologia do Ensino Superior, momento em que aprofundei os estudos sobre metodologia do ensino e sobre os processos de aprendizagem, planejamento e organização do trabalho pedagógico e avaliação. A realização desse curso representou uma etapa importante em minha trajetória acadêmica e profissional, pois possibilitou uma maior compreensão da História da Educação no Brasil, do processo de formação de professores e da consequente adoção de metodologias de ensino inadequadas que, junto com outros fatores, poderia ser a causa dos altos índices de reprovação em Matemática.

Entre as atividades desenvolvidas no curso de Pedagogia, com o apoio das leituras realizadas na disciplina Fundamentos e Metodologia da Matemática, orientei grupos de licenciandos a elaborar projetos de trabalho com a comunidade escolar. Esses projetos tinham como objetivo reorientar a 
aprendizagem como forma de atenuar as dificuldades de aprendizagem de alguns alunos que, por algum motivo, não conseguiam compreender, dominar e, consequentemente, não conseguiam operar com os conceitos matemáticos. Isso me motivou a fazer a proposição, junto a um grupo de graduandos, de um projeto de Extensão Universitária ${ }^{3}$ que envolveu alunos e professores das séries iniciais do Ensino Fundamental, da rede estadual de ensino da cidade de Barreiras - Bahia.

O projeto teve por objetivo oferecer aos alunos, os quais se encontravam em situação de dificuldade, uma oportunidade de "olhar a matemática com outros olhos". Nesse projeto, trabalhamos com os alunos que foram classificados por seus professores como incapazes de aprender matemática e apresentavam médias inferiores a 4,0 (quatro). Como o propósito inicial era apenas oferecer aulas de "reforço", as primeiras atividades não se diferenciaram muito do ensino tradicional, mas já demonstravam a preocupação com um tipo de trabalho que privilegiasse os questionamentos e as hipóteses dos alunos.

Inicialmente, foi realizado um levantamento dos conteúdos mais problemáticos, segundo a ótica do professor, e selecionadas diversas estratégias de exploração desses conteúdos. Tais estratégias priorizavam a compreensão dos conceitos, por meio da resolução de problemas, do conhecimento da história da matemática, do uso de jogos e de desafios.

No desenvolvimento das atividades matemáticas, observamos que as crianças consideradas "problemáticas", por seus professores, demonstravam uma forma diferente de resolver os problemas. Elas os resolviam, às vezes, com desenhos, com várias operações, com riscos de pauzinhos no papel, e registravam os cálculos pensados de uma maneira informal, sem muita preocupação com a forma padrão de registro e, algumas vezes, quando tentavam registrar utilizando a forma padrão não conseguiam.

No decorrer do trabalho, percebemos que aquelas crianças, classificadas na escola como incapazes, apresentaram uma forma própria de resolver os problemas. Elas chegavam, a sua maneira, às respostas corretas. Entretanto, tais produções não eram conhecidas e/ou aceitas pela escola. As atividades desenvolvidas no projeto serviram como de fonte de dados para as aulas da disciplina Fundamentos e Metodologia do Ensino da Matemática. Além disso, elas forneceram materiais de base para engajar-me, cada vez mais, nos estudos da área de educação matemática e também serviram para a construção da proposta de pesquisa para o curso de Mestrado.

\footnotetext{
${ }^{3}$ Projeto de Extensão Universitária - Matemática Prática - Convênio UNEB/FNDE- Publicado no Diário Oficial de 11/03/1996, desenvolvido pelos alunos do Curso de Pedagogia do CESB/UNEB na disciplina Prática de Ensino e Estágio Supervisionado I, nos anos de 1996/1997, com crianças da rede de ensino estadual, do município de Barreiras, que apresentavam médias inferiores a 4,0 (quatro), com objetivo inicial de oferecer aulas "reforço" e, ao mesmo tempo, pesquisar novas metodologias de ensino da matemática.
} 
Essa trajetória permitiu a construção das primeiras questões de pesquisa: Qual o processo de construção de conceitos matemáticos dos educandos em seus diferentes contextos culturais? Como podemos contextualizar os problemas sem ter conhecimento dos contextos e dos processos de construção de conceitos por parte dos alunos? Como adequar os conteúdos e os problemas às formas de pensar construídas pelo indivíduo no seu contexto cultural? É legítimo “ensinar”, sem oportunizar a compreensão, sem respeitar o caminho que o educando percorre na construção de conceitos? Qual a relação entre a mediação realizada pelo professor e o processo de construção de conceitos pelo educando? A maior indagação estava em: como justificar a contradição entre o desempenho satisfatório das crianças nas atividades desenvolvidas no projeto e a classificação imposta pela escola?

Assim, em 2000, ocorreu meu ingresso no Mestrado em Educação da Faculdade de Educação - na Universidade de Brasília -, com um projeto em busca de respostas a essas questões. A pesquisa de campo foi realizada em uma escola pública da rede municipal de Barreiras. Trabalhamos com a mediação do professor no processo de construção de conceitos matemáticos em uma classe de alfabetização. A fim de compreender a aprendizagem dos conceitos matemáticos, tomou-se por base a Teoria dos Campos Conceituais (TCC) de Gérard Vergnaud (1990), uma vez que se pretendia explicitar os esquemas mentais presentes na ação dos sujeitos. E, para discutir a ação da professora na proposição de situações que provocassem o sujeito a mobilizar os conceitos, recorremos à Teoria das Situações Didáticas de Brousseau (1996).

Os resultados mostraram uma estreita relação entre a ação da professora e a ação das crianças. À medida que a ação da professora se pautou em evidências de aprendizagem, as atividades propostas tornaram-se mais produtivas e significativas para as crianças. Isso provocou uma mudança de postura da professora e o maior envolvimento das crianças. Vimos que a compreensão do modo como o sujeito mobiliza conceitos em diferentes situações contribuiu para a mediação pedagógica. O processo de pesquisa transformou-se em um espaço de formação para a professora e para a pesquisadora. O relatório desse trabalho está em Porto Nascimento (2002) Dissertação de Mestrado com o título: A pesquisa como instrumento de mediação num ambiente de aprendizagem matemática: aprende a criança, aprende a professora e aprende a pesquisadora.

Após a defesa, retornei as minhas atividades docentes na UNEB - Campus IX - Barreiras BA e tive a oportunidade de, além de ministrar palestras para expor os resultados, orientar monografias cujo objeto de estudo situava-se na área de Educação matemática. Após a conclusão do curso de Mestrado, os encontros na escola em que se realizou a pesquisa diminuíram. Algumas professoras ingressaram no Curso de Licenciatura em Pedagogia e, após a conclusão do curso, se 
tornaram coordenadoras pedagógicas e participam de vários cursos de atualização e aperfeiçoamento e, ainda hoje, multiplicam ideias discutidas na época da pesquisa.

As oportunidades para um profissional com Mestrado em Educação em uma cidade do interior do Estado da Bahia são sempre ampliadas. Assim, em 2002, junto com uma equipe de docentes de nível superior, coordenamos o Curso Normal Superior na Faculdade São Francisco de Barreiras. Essa instituição de ensino, em parceria com algumas prefeituras municipais, abriu espaço para a formação em nível superior de uma demanda de professores em exercício que, por suas necessidades profissionais e pessoais, não ingressavam nas vagas oferecidas em Instituições de Ensino Superior Públicas em que as vagas são limitadas e os cursos oferecidos são diurnos, o que implicaria em deixar de trabalhar, pelo menos em meio período para "fazer faculdade".

A atuação como coordenadora desse Curso ocorreu de dezembro de 2002 a março de 2005. E, além de ser responsável pela coordenação do curso, eu também ministrava as disciplinas Ensino de Matemática I e II. Como as acadêmicas eram, em sua maioria, professoras em exercício, houve a oportunidade de estar próxima das pessoas que assumiam a função de ensinar matemática às crianças matriculadas na rede municipal de ensino em Barreiras e nos municípios circunvizinhos. Na época, fiquei preocupada com as dificuldades que as professoras mostravam em lidar com a Matemática. Essas dificuldades já tinham sido diagnosticadas no Curso de Licenciatura em Pedagogia, mas sempre se tem a impressão (equivocada) de que o licenciando ainda está se preparando para uma atuação futura e o "não saber" é "menos grave". Mas a constatação de que um professor atuante tem uma relação não muito confortável com uma área de conhecimento que constitui grande parte do currículo do Ensino Fundamental foi, no mínimo, preocupante.

Em 2007, além de continuar a ministrar aulas no Curso de Pedagogia, iniciei as atividades docentes na Licenciatura em Matemática. Foi um período de muitas controvérsias, pois alguns professores do curso não se viam nem agiam como formadores de professores. E isso se refletia na visão do licenciando que se recusava a estudar psicologia e didática, entendiam que o requisito para ser professor era apenas o conhecimento do conteúdo. A cada semestre, enfrentávamos inúmeros desafios na conquista dos licenciandos para a inserção na área de educação matemática.

Além dessa atividade direta com professores em exercício, após o ano de 2007, pude participar do Programa Especial de Graduação REDEUNEB 2000, que teve como objetivo oportunizar aos professores da rede municipal a realização de um curso de graduação em Pedagogia sem sair de seu município e sem afastar-se de suas atividades profissionais, ou seja, o professor formador deslocava-se do município sede (no caso Barreiras - UNEB- Campus IX) para o município em que residiam os licenciandos. Naquela ocasião, ministrei as disciplinas Ensino de Matemática I e II nos municípios de 
Cristópolis, Catolândia e Formosa do Rio Preto. Essa experiência apenas aumentou a minha preocupação com a relação que a maioria dos professores do Ensino Fundamental tem com a Matemática.

No ano de 2009, surgiu uma vaga na Licenciatura em Matemática na Universidade Federal da Bahia e optei pela realização de um novo concurso, pela possibilidade de maior dedicação à pesquisa. Concorri a essa vaga e fui aprovada. Ingressei na UFBA na condição de professora Assistente, dedicação exclusiva, especificamente no Instituto de Ciências Ambientais e Desenvolvimento Sustentável - ICADS, localizado em Barreiras - Bahia.

O ingresso na UFBA abriu espaço para a pesquisa. Isso realmente significou uma mudança em minha vida profissional. Foi nesse espaço que participei como colaboradora em 2009 e 2010 de um projeto de pesquisa proposto pelo GPEMEC/UESC- Ilhéus/Bahia, sobre o domínio das Estruturas Aditivas, financiado pela FAPESB, e que foi realizado em nove regiões do Estado. Naquela oportunidade, estive em contato com representantes do Núcleo Regional da Sociedade Brasileira de Educação Matemática - Regional Bahia e com a professora Sandra Magina da PUCSP, que muito contribuiu para ampliar minhas ações de pesquisa. Vários workshops foram realizados para que o grupo compreendesse o significado da pesquisa e aprofundasse os estudos sobre a Teoria dos Campos Conceituais de Vergnaud, especificamente sobre as estruturas aditivas.

É importante registrar que as atividades de ensino na UFBA acontecem tanto no curso de Licenciatura em Matemática, nas disciplinas ligadas à área de educação matemática, quanto em Matemática Básica para os primeiros semestres do Curso de Licenciatura em Geografia e de Bacharelado em Administração. Nessas atividades de ensino, é possível, infelizmente, vivenciar junto aos acadêmicos o que os resultados das avaliações em larga escala ${ }^{4}$ apontam: os baixos índices de proficiência e a falta de habilidade em lidar com os conceitos básicos nessa área de conhecimento. Os acadêmicos queixam-se de não compreender os conteúdos e alguns afirmam não ter estudado determinados conteúdos em nenhuma das séries do Ensino Fundamental e Médio. Isso reforça nosso desejo de apoiar os professores do Ensino Fundamental.

\footnotetext{
${ }^{4}$ Para mais informações sobre a sistemática da avaliação em larga escala, pode-se acessar a página do MEC: http://provabrasil.inep.gov.br/resultados-2013.

E no site http://www.bbc.co.uk/portuguese/noticias/2015/02/15 encontram-se análises, como um levantamento divulgado pelo movimento Todos pela Educação que afirma que: "No $9^{\circ}$ ano, o último do ensino fundamental, a maior parte dos alunos não está sendo capaz de entender textos narrativos longos e com vocabulário complexo, não consegue resolver problemas matemáticos ou usar porcentagens e medidas padronizadas (como $\mathrm{km} \mathrm{e} \mathrm{kg}$ ), o que seria esperado nessa etapa, segundo métricas do próprio governo. (...) A partir da comparação de notas do exame nacional Prova Brasil com metas - expectativas de notas - específicas à realidade de cada cidade estudada, apenas 10,8\% dos municípios brasileiros têm alunos com o aprendizado adequado ao que se espera no $9^{\circ}$ ano (contra $28 \%$ em 2011) em matemática. Em apenas $10 \%$ dos municípios o conhecimento em matemática é adequado para alunos do $9^{\circ}$ ano. (...) No que diz respeito ao $5^{\circ}$ ano do ensino fundamental, a avaliação constatou que apenas $48 \%$ dos municípios tinham, em 2013 , alunos com conhecimento adequado em português (índice semelhante ao de 2011) e 61,7\% tinham conhecimento adequado em matemática (contra 69\% em 2011)".
} 
Em relação à formação de professores, outra atividade realizada como projeto de extensão junto à Universidade Federal da Bahia ${ }^{5}$ - Campus de Barreiras, entre 2009 e 2011, foi a revisão da Proposta Curricular para o Ensino Fundamental de 09 anos e a realização de cursos de formação promovidos pela Secretaria Municipal de Educação. Os encontros ocorriam uma semana a cada dois meses e neles eram construídas e validadas sequências de ensino junto aos professores do $1^{\circ}$ ao $3^{\circ}$ ano do Ensino Fundamental.

Participei, em 2012 e 2013, como Coordenadora Pedagógica da área de Matemática, do Programa Pró-Letramento ${ }^{6}$, proposto pelo Ministério da Educação com o objetivo de promover a formação continuada de professores dos anos iniciais do Ensino Fundamental da rede pública de ensino. Essa iniciativa visava incentivar a reflexão e a construção do conhecimento como processo contínuo de formação docente, de modo a desenvolver, nas escolas, a cultura de formação continuada. Uma das minhas principais responsabilidades no projeto foi estudar e planejar os encontros de formação com um grupo de 06 formadores que atuaram em 06 polos - regiões do Estado da Bahia: dois polos em Salvador - Região Metropolitana e Região da Chapada Diamantina que se deslocou de Seabra para Salvador, Barreiras - Região Oeste, Juazeiro - Região Norte, Eunapólis - Região Sul e Extremo Sul e Guanambi - Região Sudoeste.

De modo paralelo a esta atividade, continuei a dar assistência ao grupo de professores dos Anos Finais do Ensino Fundamental que cursavam a Licenciatura em Matemática, pelo Programa Plataforma Freire. Comecei a trabalhar com esse grupo, no segundo semestre do curso, com a disciplina Metodologia da Pesquisa, oportunidade em que revisei com os graduandos, além das linhas gerais sobre a pesquisa, as leituras específicas na área de Pesquisa Qualitativa em Educação Matemática. Em seguida, assumi a disciplina Estágio Supervisionado I, em que discutimos, com base no texto de Pimenta e Lima (2004) Por que o estágio para quem já exerce o magistério: uma proposta de formação contínua. Foi interessante convencer o grupo sobre a importância do espaço de reflexão que o estágio no exercício da docência proporciona. Foi difícil acalmá-los quanto a nossa presença em suas salas de aula. Essa atividade permitiu estar bem próxima da sala de aula, dos alunos e dos professores - alunos que atuavam nos anos finais do ensino fundamental.

\footnotetext{
${ }^{5}$ Desde junho de 2013, foi criada a Universidade Federal do Oeste da Bahia - UFOB, a partir do desmembramento do Instituto de Ciências Ambientais e Desenvolvimento Sustentável - ICADS, que foi uma unidade avançada da UFBA, sediada em Barreiras, desde 2006.

${ }^{6} \mathrm{http}: / /$ portal.mec.gov.br : O Pró-Letramento - Mobilização pela Qualidade da Educação - é um programa de formação continuada de professores para a melhoria da qualidade de aprendizagem da leitura/escrita e matemática nos anos/séries iniciais do ensino fundamental. O programa é realizado pelo MEC, em parceria com universidades que integram a Rede Nacional de Formação Continuada e com adesão dos estados e municípios. Podem participar todos os professores que estão em exercício, nas séries iniciais do ensino fundamental das escolas públicas.
} 
Essas atividades tiveram como eixo comum a formação de professores. No programa PróLetramento essa formação encontrou-se distante, pois fiz o estudo do material produzido por especialistas de diferentes centros de pesquisa em Universidades do país e, junto com os formadores, planejei o encontro de formação dos orientadores de estudo. O grupo de formadores deslocava-se da unidade sede em Barreiras para os polos e esses, por sua vez, realizavam os encontros com os orientadores de estudo, que trabalhavam, em seus municípios, com os professores cursistas atuantes em classes dos anos iniciais do Ensino Fundamental. Os orientadores de estudo mantinham contato direto com os formadores e foi possível vislumbrar evidências de mudança no saber e no fazer dos professores cursistas. É importante dizer que inserimos, nos momentos de estudo com os formadores, os resultados de pesquisa de diversos estudiosos em educação matemática e tivemos como foco, mesmo a distância, a sala de aula e a aprendizagem da criança.

Do mesmo modo, nas observações e nos projetos e relatórios dos acadêmicos da Plataforma Freire, foi possível perceber que as orientações teórico-metodológicas transformaram-se em ações reveladas no trabalho em sala de aula. Pude observar que alguns licenciandos foram mais ousados, enquanto outros ainda preferiram permanecer em algum lugar "aparentemente" seguro, agarrandose a práticas que, em algum momento de sua trajetória profissional, mostraram-se adequadas.

Posso afirmar que, entre essas atividades, sinto-me mais produtiva quando me coloco ao lado dos professores dos anos iniciais do Ensino Fundamental, quer seja nos momentos de estudo, quer seja acompanhando as aulas, aprendendo com esse profissional a falar com a criança, obrigando-me a compreender o desenvolvimento cognitivo da criança e, ao mesmo tempo, o desenvolvimento cognitivo do adulto. Algo ainda novo para mim é pensar sobre o adulto em processo de aprendizagem. É muito intrigante observar e perceber as mudanças no modo como o professor dialoga com a criança. Vê-se que, à medida que ele se envolve com os estudos e compreende melhor o processo de formação de conceitos, a sua forma de mediação se transforma.

Ao somar todas essas experiências, configurou-se o principal objetivo de ter buscado o ingresso em um curso de Doutorado, principalmente na linha de pesquisa Educação em Ciências e Matemática - Eixo de interesse: Educação Matemática - aprendizagem e formação. Essas experiências, nas quais constatamos o desenvolvimento de novas práxis pedagógicas para o ensinar e o aprender matemática nos anos iniciais do Ensino Fundamental, indicaram possibilidades de promover reflexões, problematizações e mudanças na prática do professor. Tal mudança ocorre por meio da colaboração entre pesquisador e professores em um processo de investigação permanente, em que, a todo o momento, são postas em observação e análise as práticas docentes e discentes. Esse fato possibilita a constante reflexão sobre o fazer pedagógico e sua implicação com a 
aprendizagem, além de desenvolver uma postura investigativa do professor que, ao participar dos estudos e discussões sobre o aprender e o ensinar matemática, compreende o significado da pesquisa.

A literatura em educação matemática (CURI; PIRES, 2008; FIORENTINI; NACARATO, 2005; NACARATO; MENGALI; PASSOS, 2014; REIS; FIORENTINI, 2007, entre outros) indica resultados importantes em que o envolvimento em um processo de pesquisa evidenciou o desenvolvimento profissional do professor. Observa-se a necessidade de analisar esses resultados e de promover mais pesquisas com essa característica, de modo a dar espaço de participação aos professores em um processo em que eles decidam o que e como estudar, problematizando a sua prática.

Como exemplo, posso afirmar que conhecer e vivenciar o projeto de pesquisa-ação de Muniz (2009) oportunizou o desenvolvimento de inúmeras aprendizagens sobre o significado da matemática nos anos iniciais, sobre a produção matemática das crianças e a mediação do professor no processo de construção de conceitos. A insistência do autor em atentar-se à necessidade de desenvolver, junto aos professores, um novo olhar para a produção do conhecimento matemático, realizado pela criança no contexto da escola, instiga-nos a aproximarmo-nos dos professores e a pensar sobre o significado e sobre a constituição desse novo olhar, que implicará na mudança de conceitos e concepções e na construção de novas práticas. Os pressupostos epistemológicos e metodológicos do trabalho investigativo, realizado por Muniz (2009), podem ser norteadores de outras pesquisas e da criação de espaços de estudos e de discussão no espaço da escola.

Interessa-nos o professor polivalente, com formação em Pedagogia, que trabalha nas turmas dos anos iniciais do Ensino Fundamental e é responsável por ensinar conteúdos de várias áreas do conhecimento, entre elas, a Matemática. Com a ampliação do período escolar para nove anos, algumas mudanças estão sendo exigidas. Tem-se, agora, em sala, crianças de seis anos que antes ingressavam nas classes de alfabetização. Bem mais que em outros momentos da educação em nosso país, exige-se que as instituições educacionais se organizem para garantir o direito de aprendizagem proposto pelo Pacto Nacional para Alfabetização na Idade Certa. No texto "Elementos conceituais e metodológicos para definição dos Direitos de Aprendizagem e desenvolvimento do ciclo de alfabetização ( $1^{\circ}, 2^{\circ}$ e $3^{\circ}$ anos) do Ensino Fundamental", tem-se que:

Os Direitos e Objetivos de Aprendizagem e Desenvolvimento que envolvem o processo de alfabetização matemática estão atrelados à compreensão dos fenômenos da realidade. Esta compreensão oferece ao sujeito as ferramentas necessárias para que ele possa agir conscientemente sobre a sociedade na qual está inserido. É papel da escola criar as condições necessárias para que o sujeito possa servir-se dessas ferramentas em suas práticas sociais. Assim, o conceito de letramento matemático está diretamente ligado à concepção 
de Educação Matemática e tem como espinha dorsal a resolução de situações-problema e o desenvolvimento do pensamento lógico. (BRASIL, 2012, p. 59)

Assim, compete ainda ao profissional professor, articulado com as diferentes instâncias institucionais e curriculares, bem mais do que acontecia antes, alfabetizar essa criança em diferentes linguagens, inclusive em linguagem matemática ${ }^{7}$. E, ao avançar nos anos iniciais, como já acontecia antes da ampliação do Ensino Fundamental para nove anos, o professor deve realizar, em sala de aula, um trabalho que visa aproximar a criança dos conteúdos matemáticos, definidos como necessários a melhor compreensão da realidade e, consequentemente, imprescindíveis para uma melhor atuação na sociedade.

Essa exigência coloca sobre o professor uma grande responsabilidade. Questiona-se o apoio institucional que esse profissional tem para conseguir desenvolver essa função, assumida no momento em que decide, por circunstâncias diversas, tornar-se professor. Sabe-se que as políticas públicas, voltadas para a área de educação, nem sempre favorecem o trabalho do professor. O espaço escolar nem sempre conta com um coordenador pedagógico, com um gestor consciente e preocupado com o fazer pedagógico, nem com outros profissionais de apoio, como assistentes sociais e psicopedagogos. Enfim, o professor, em muitas regiões do país, encontra-se sozinho em sala de aula ao decidir e executar sua ação de planejar, ensinar e avaliar. Os resultados da ANA $^{8}$ 2013 mostraram um quadro preocupante em alfabetização, principalmente em alfabetização matemática. A prova foi aplicada, no ano de 2013, a cerca de 2,3 milhões de crianças do $3^{\circ}$ ano (8 anos de idade) da rede pública. Os resultados indicaram a existência de um número significativo de crianças no $3^{\circ}$ ano de alfabetização que não conseguiam analisar informações em gráfico de barras simples ou resolver problemas de subtração com números de até dois algarismos.

Esses dados apontaram para um grave problema que se configura na escola pública dos anos iniciais. Por meio deles foi possível identificar a necessidade de unir as professoras alfabetizadoras em busca de propostas que contribuíssem para o desenvolvimento de novas práxis pedagógicas em alfabetização matemática, pois se trata de um processo importantíssimo e de um momento

\footnotetext{
${ }^{7}$ Muniz (2015) em comunicação pessoal chama a atenção para o fato de não é possível desconsiderar que: "Se há aprendizagem (ou não) isto é de autoria ontológica do ser aprendente, e não estrita e linearmente consequência de ações didático-pedagógicas. Temos de assumir tanto a aprendizagem quanto a alfabetização como de fato um sistema complexo, ainda mais num contexto contemporâneo de direito da aprendizagem. Deste modo, coloca-se um desafio e um paradoxo: como garantir uma aprendizagem se este é um fenômeno de realização psicológica do sujeito, onde educadores e instituição não podem ter controle absoluto pelo mesmo?"

${ }^{8}$ Essa avaliação está direcionada para unidades escolares e estudantes matriculados no $3^{\circ}$ ano do ensino fundamental, fase final do Ciclo de Alfabetização, e insere-se no contexto de atenção voltada à alfabetização prevista no Pacto Nacional pela Alfabetização na Idade Certa (PNAIC). Instituído pela Portaria n ${ }^{\circ} 867$, de 4 de julho de 2012, o Pacto constitui um compromisso formal assumido pelos governos Federal, do Distrito Federal, dos Estados e dos Municípios de assegurar que todas as crianças estejam alfabetizadas até a conclusão do Ciclo de Alfabetização. Disponível em: http://download.inep.gov.br/educacao_basica/saeb/2013/livreto_ANA_online.pdf
} 
fundamental na vida da criança, que convive com os conceitos matemáticos em inúmeras atividades cotidianas e terá, ao ingressar formalmente no processo de escolarização, os primeiros contatos com o conhecimento matemático sistematizado.

Pesquisar sobre a alfabetização em matemática: questão de pesquisa, objetivos e tese

Uma questão que há muito inquieta os sujeitos envolvidos em educação é: De que forma é possível conquistar o professor e aproximá-lo dos resultados dos estudos desenvolvidos por pesquisadores que evidenciam formas diferenciadas de planejar, realizar as aulas, avaliar e qualificar a aprendizagem? Talvez haja um problema nessa questão, pois ao invés de conquistar o professor para aproximá-lo de estudos desenvolvidos por outros, às vezes alheios ao seu trabalho e as suas condições de exercício da complexa tarefa de ensinar, uma alternativa seria que esse professor aprendesse a tomar a sua prática como objeto de análise. Isso porque, ao se colocar em uma posição crítica em relação ao seu trabalho, ele poderia criar instrumentos para observar, registrar, avaliar, reavaliar. A esse respeito, concorda-se com Muniz (2015) quando afirma que:

\footnotetext{
$\mathrm{Na}$ tradição da pesquisa em educação, em alguns estudos, o professor é somente objeto da investigação, e não participante. Assim, as produções e conhecimentos gerados ficam sujeitos à divulgação, assimilação futura, após conclusão da pesquisa. Acredita-se ser possível conceber um trabalho de investigação, centrado nas práxis da aprendizagem matemática, onde os professores sejam, ao longo da mesma, coautores da geração de novos saberes, não se limitando à disseminação do conhecimento gerado após a conclusão do processo. (Comunicação pessoal - Reunião de orientação, 2015)
}

Pelas experiências e pelo conhecimento sobre os professores atuantes no município em que foi realizada a pesquisa, já acreditávamos que eles poderiam tomar a posição de estudiosos de sua prática. Porém, entendemos que ainda é essencial que outros pesquisadores universitários venham a atuar junto a esses professores para construir parcerias que possam ajudá-los a constituir-se como profissionais críticos e autônomos em relação a sua própria profissão e a sua função na sociedade.

A partir dessas considerações, reafirmamos que foi possível aliar a pesquisa à ação, dado o desejo da pesquisadora em atender às solicitações das professoras nos diversos espaços de trabalho coletivo (curso de graduação/programas de formação/projetos de análise curricular/grupos de estudo) em que pesquisadora e professoras encontraram-se juntos como professora formadora professora em formação. Destaca-se que, no ano de 2013, no município, como em outros municípios do país, tiveram início os encontros de formação do PNAIC - Área de Linguagem, com o objetivo de promover a formação continuada aos professores que atuavam no Ciclo de 
Alfabetização. Desde então, se observou a expectativa das professoras participantes do programa quanto aos encontros de formação em alfabetização matemática que ocorreram em 2014.

Assim, em 2014, mesmo com a permanência em Brasília para cursar o segundo ano do curso de doutorado, foi possível participar de alguns encontros que aconteciam aos sábados no município de Barreiras. Nessas oportunidades, os professores revelavam sua angústia em "colocar em prática o que estava sendo ensinado". Os cadernos do Programa PNAIC acompanham toda a proposta curricular dos anos iniciais do ensino fundamental, desde a construção do conceito de número, as operações, as grandezas e medidas, a orientação e o deslocamento, as formas, a estatística. Entretanto, a relação do professor com o saber matemático nem sempre contribui para que este tenha segurança nos conteúdos a serem ensinados (MANDARINO, 2009). Esse último ponto será retomado oportunamente neste texto.

Além dos conteúdos matemáticos, nos cursos de formação continuada exploram-se também novas e diferenciadas formas de trabalhar esses conteúdos, o que exigirá do professor alguns saberes de natureza diferenciada. Como afirma Shulman (1986), é necessário o conhecimento do conteúdo; o conhecimento do conteúdo no ensino e; o conhecimento pedagógico. Nesse contexto, por mais que a equipe de formadoras em um curso de formação continuada se esforce em promover leituras, vivências de práticas, análise de experiências, na tentativa de trazer para o curso a prática do alfabetizador a fim de problematizá-la, são inúmeros os fatores que criam obstáculos e dificultam a abertura a novas formas de perceber e de realizar um trabalho com a matemática na alfabetização. Tais fatores estão relacionados às concepções, crenças, fragilidades conceituais e mesmo à desconfiança em relação a algumas propostas.

Nesse contexto, professores de diferentes escolas da rede municipal de ensino de Barreiras, alguns egressos do curso de Pedagogia (ex-alunos da pesquisadora) fizeram convites para a professora/pesquisadora ir à escola auxiliar na compreensão de orientações contidas em cadernos de cursos de formação continuada. Vimos, nessas circunstâncias, a possibilidade de juntar os nossos desejos: o desejo expresso pelos professores de estudar e melhorar sua prática e o desejo da pesquisadora de estar na escola e produzir conhecimentos junto com as professoras, constituindo um espaço legítimo de discussão - reflexão - problematização - formação - transformação. Assim, entendemos que nesse espaço poderia ser realizado um trabalho coletivo em que a prática pedagógica de alfabetização em matemática pudesse ser tomada como objeto de estudo. 


\section{Questão de pesquisa}

Os motivos que nos impeliram a constituir essa pesquisa centraram-se em vários aspectos: (i) os resultados das avaliações sobre a alfabetização em matemática; (ii) o desejo de melhor compreender a complexidade do processo de alfabetização; (iii) a crença no potencial de aprendizagem da criança; (iv) a constatação de que o professor produz conhecimentos sobre o ensinar em diferentes espaços, principalmente quando participa de espaços coletivos de reflexão e problematização de sua prática; (v) as evidências que tivemos em nossas experiências de formação e pesquisa com professores dos anos iniciais de ser possível apoiar a ação do professor, por meio da pesquisa-ação, pois esta pode se constituir como espaço de intervenção-transformação-formação.

Observamos que políticas de formação continuada voltadas ao professor de matemática, propostas pelo Ministério da Educação, como GESTAR e o PROLETRAMENTO conseguiram alguns avanços, principalmente pelo fato dos materiais didáticos disponibilizados aos professores serem construídos em acordo com os pressupostos teórico-metodológicos das pesquisas recentes em educação matemática.

Como afirmei anteriormente, o meu ingresso no curso de Doutorado sucedeu em busca de realizar a pesquisa na escola, junto com as professoras, a fim de analisar as possíveis mudanças que ocorrem na práxis da educação matemática, por meio da participação na pesquisa. E, em permanente contato com as professoras ${ }^{9}$ dos anos iniciais que, no período de 2013 (área de Linguagem) e 2014 (área de Matemática), participavam de um curso de formação continuada, fui convidada a estar em uma das escolas do município e a discutir algumas demandas surgidas pelos estudos realizados no curso.

Esse foi o momento de definição do local de realização da pesquisa, restava ajustar o foco com o delineamento da questão que, após inúmeras discussões, foi definida como: De que forma a constituição, no contexto da escola, de um espaço de reflexão, problematização, estudo e discussão sobre a prática em Alfabetização Matemática, contribui para a produção de conhecimentos pelas professoras sobre o ensinar e o aprender, de modo a construir novas práxis pedagógicas, e como essas novas práxis integram-se ao processo de formação continuada em serviço da professora alfabetizadora?

Concordamos que as professoras produzem conhecimentos sobre o ensinar e o aprender em seus diferentes espaços de trabalho, mas em nossas experiências percebemos a necessidade de

\footnotetext{
${ }^{9}$ Nos anos iniciais do ensino fundamental predominam as mulheres, professoras, por esse motivo neste texto iremos nos referir as professoras.
} 
ressignificar os conhecimentos produzidos. Assim, acreditávamos que em um espaço coletivo de reflexão, problematização, estudo e discussão sobre as práxis de Alfabetização Matemática, constituído na escola, as professoras superariam as dificuldades conceituais e metodológicas que criavam obstáculos a novas aprendizagens e à ressignificação dos conceitos matemáticos e, consequentemente, impediam a criação de planos de trabalho que realmente fossem promotores da aprendizagem da criança.

\section{$\underline{\text { Objetivos }}$}

Percebemos que a relevância desta pesquisa está ligada à possibilidade de trabalhar na escola, junto com as professoras alfabetizadoras, no momento atual em que a sociedade se preocupa em garantir os Direitos de Aprendizagem da criança e em que se pretende promover a alfabetização de todas as crianças até os oito anos de idade. Com essas convicções e o propósito de responder à questão de pesquisa, definimos como objetivo geral: Analisar um processo de construção de novas práxis pedagógicas pelas professoras alfabetizadoras quando elas participam, no contexto da escola, de estudos, reflexões, problematizações e discussões sobre alfabetização em matemática e, investigar como essas novas práxis se integram à formação continuada da professora alfabetizadora.

\section{$\underline{\text { Tese }}$}

Coerentes com a questão de pesquisa e com os objetivos, defendemos a seguinte tese: A constituição de um espaço de problematização, reflexão, estudo e discussão sobre as práxis em Alfabetização Matemática configura-se como formação continuada em serviço das alfabetizadoras. A relação dinâmica entre teoria e prática, neste espaço, dentro da escola, contribui para a produção de conhecimentos sobre a matemática, seu ensino e sua aprendizagem que se traduzem em diferenciadas práxis em alfabetização matemática que podem constituir-se em práticas emancipatórias, principalmente quando se consideram os aspectos ideológicos, históricos, culturais e políticos em que uma escola, com seu grupo de trabalho tem suas ações implicadas pelos determinantes da regulação estrutural do sistema de ensino.

As informações produzidas, ao longo do processo de pesquisa, foram organizadas em quatro capítulos. Norteados pela questão de pesquisa, no primeiro capítulo, foram discutidos temas fundamentais como: a matemática nos anos iniciais, a alfabetização matemática, o processo de aprendizagem, a formação de professores, a formação de professores que ensinam matemática nos 
anos iniciais do Ensino Fundamental, a relação do professor com o saber, o conceito de práxis, práxis pedagógica e práxis emancipatória.

O segundo capítulo objetiva afirmar a possibilidade e a potencialidade da pesquisa na escola transformar-se em um espaço formativo. Definimos os pressupostos teóricos que sustentaram nossa metodologia de trabalho, discutimos a perspectiva de a pesquisa desenvolver-se em relação com uma ação ou com a resolução de um problema coletivo. No nosso caso, o coletivo foi um grupo de alfabetizadoras em busca de aperfeiçoar o trabalho com a matemática escolar no Ciclo de Alfabetização. Descrevemos o cenário da pesquisa, as profissionais que atuaram durante a construção de informações, os procedimentos de produção das informações e o sistema de categorias.

Apresentamos, no terceiro capítulo, a análise da primeira categoria que trata da relação entre a formação continuada em serviço na escola e as mudanças na prática em alfabetização matemática. Sintetizamos, nesse capítulo, as aprendizagens, as crenças e as concepções a respeito do ensino e da aprendizagem de matemática; a relação e o diálogo entre teoria e prática, a produção de conhecimentos, a ampliação do conceito de alfabetização matemática e a reorganização do trabalho pedagógico, enfim, a construção da autonomia intelectual que nos orientou no caminho da prática à práxis.

No quarto capítulo, apresentamos a segunda categoria. Agrupamos e analisamos as evidências de que o conceito de alfabetização foi um forte norteador da prática. A ampliação desse conceito implicou em mudanças nos planos de trabalho e materializou-se na prática pedagógica das alfabetizadoras, numa explícita relação entre o que se pensa, o que se estuda sobre a alfabetização matemática e a prática em sala de aula. Selecionamos, nessa categoria, as informações referentes à exploração dos conteúdos dos eixos números e operações.

Nas considerações, indicamos inquietações consequentes das análises e sínteses realizadas ao longo deste texto, que apontam para a necessária continuidade dessa pesquisa-formação que revelou possibilidades de formação continuada em serviço, dentro da escola, em parceria com a universidade. 


\section{CAPÍTULO 1}

\section{A MATEMÁtiCA, A ALFABETIZAÇÃO E A FORMAÇÃO DA ALFABETIZADORA: ALGUNS PRESSUPOSTOS TEÓRICOS}

Nesse primeiro capítulo, analisamos os motivos que justificam a inserção da matemática no currículo escolar dos Anos Iniciais do Ensino Fundamental, especificamente no Ciclo de Alfabetização ( $1^{\circ}, 2^{\circ}$ e $3^{\circ}$ anos do ensino fundamental). Entendemos a matemática como construção humana, resultante da ação do homem sobre a natureza. Como um corpo de conhecimentos constituído pelo homem, ela é um bem cultural da humanidade e, por esse motivo, deve ser acessada por todas as crianças, principalmente no contexto escolar.

Assim, nesta pesquisa, que teve como foco a práxis em alfabetização matemática, foi fundamental compreender tanto o conceito de alfabetização matemática quanto o de formação da professora alfabetizadora. Desse modo, expomos uma síntese das ideias que fundamentaram nosso trabalho: a matemática nos anos iniciais, o conceito de alfabetização matemática, o processo de aprendizagem matemática, o ensinar matemática na alfabetização, a práxis em alfabetização matemática, a formação do professor e a formação da alfabetizadora.

\subsection{A MATEMÁTICA NOS ANOS INICIAIS DO ENSINO FUNDAMENTAL}

Ao pensar nos motivos para explorar o conhecimento matemático nos anos iniciais do Ensino Fundamental, reflete-se que essa área de conhecimento faz parte da vida e está presente em inúmeras situações cotidianas. Muito já foi dito sobre esse fato: a presença da matemática no dia a dia e a necessidade de conhecer, pelo menos, os conceitos básicos dos números, das operações, das medidas, das formas, do espaço e do tratamento da informação. As questões que se colocam são: como fazer com que a criança se aproxime dessa área de conhecimento, além do conhecimento que é construído em situações rotineiras? Como inserir a criança no universo da matemática na escola, sem, no entanto, distanciá-la da vida?

Ao tratar esse tema, é importante buscar resposta para uma questão que sempre está presente nos estudos da área de educação matemática: quais motivos justificam a presença da matemática no currículo do Ensino Fundamental? D’Ambrósio (1990) apresenta motivos que justificam a inclusão da matemática nos programas escolares e ajuda a compreender a matemática como uma atividade humana: 
- por ser útil como instrumentador para a vida;

- por ser útil como instrumentador para o trabalho;

- por ser parte de nossas raízes culturais;

- por ajudar a pensar com clareza e a raciocinar melhor;

- por sua beleza intrínseca como construção lógica e formal.

Assim, o autor nos convida a ver aspectos essenciais dessa ciência que nasceu dos problemas práticos enfrentados pelo homem e evoluiu a um alto nível de abstração. É possível acrescentar ao que propõe D’Ambrósio (1990) que aprender matemática auxilia na construção da autoimagem e autoconfiança no aprender, a aceitar desafios e a resolver problemas. Vê-se que, além de ser importante na vida, no trabalho, essa ciência tem raízes culturais e, quando bem compreendida, pode realmente contribuir para o exercício do pensar. Sua forma lógica ainda é admirada por todos os que não carregam traumas em sua relação com a matemática.

Observa-se que os pesquisadores em educação matemática buscam, em seus trabalhos, desmistificar a ideia de que a matemática é abstrata e inalcançável para muitos, acessível apenas a algumas poucas mentes brilhantes. Tem se tentado convencer as pessoas de que esse é um conhecimento útil, necessário e possível de ser compreendido e de ser produzido, inclusive pelas “crianças pequenas”. Nesse contexto, Muniz (2009b) traz evidências das produções matemáticas das crianças das classes de Ensino Fundamental e convida o leitor a refletir se o que é produzido pela criança é de fato conhecimento matemático. Em uma discussão sobre a produção de notações matemáticas e seu significado, o autor nos apresenta as contribuições do conhecimento das estratégias de pensamento subjacentes às produções matemáticas das crianças. Para ele:

\begin{abstract}
Vislumbrar a complexa rede de conceitos atribuídos a cada estratégia resolutiva e o poder de autorregulação da atividade realizada pelo aluno são temas inevitáveis das ciências da educação. A revelação, o reconhecimento, a análise e a valorização dos esquemas que sustentam as estratégias de ação podem trazer nova luz à postura pedagógica do professor, pois é por meio deles que podemos melhor compreender os conhecimentos em ação, as potencialidades, as incompletudes, os desvios e os atalhos, as ressignificações, os erros e os obstáculos, quase sempre presentes nas produções matemáticas em sala de aula. (MUNIZ, 2009b, p. 115)
\end{abstract}

Essa nova forma de ver as produções das crianças exige um novo modo de ver a matemática. Por isso, acredita-se que o professor verá esse conhecimento como acessível às crianças se aprender a ler/compreender o que é produzido por elas. Isso exigirá, do mesmo modo, que a matemática seja acessível para a professora.

As pesquisas seguem nesse sentido, por exemplo, Zunino (1995) discute as compreensões e incompreensões das crianças do Ensino Fundamental em relação a alguns tópicos importantes do 
currículo de Matemática para os anos iniciais. Em uma pesquisa realizada em escolas públicas da Venezuela, a autora entrevistou pais, professores e as crianças, além de aplicar um instrumento diagnóstico que tomou como objeto de estudos o significado que as crianças atribuem ao Sistema de Numeração Decimal, com destaque para o valor posicional, as operações e a resolução de problemas. Ela constatou que:

Muitas crianças renunciam a suas possibilidades de pensar acerca do que estão aprendendo,
que são muitas as que estão acostumadas a colocar em prática procedimentos sem perguntar
as razões que lhes dão origem. Por que o fazem? É possível que a prioridade dada ao ensino
de mecanismos - em detrimento da formulação de problemas que permitam a construção de
relações e operações - as tenha convencido de que o conhecimento matemático consiste em
um conjunto de regras mais ou menos arbitrárias e incompreensíveis. (ZUNINO, 1995,
p.190)

Essa atitude das crianças quanto à matemática tem relação com o que os adultos, com os quais convivem, pensam sobre essa área de conhecimento, inclusive o professor. Zunino (1995) afirma que caso a escola assumisse que fazer matemática é muito mais do que fazer contas, seria possível conseguir tanto que as crianças adquirissem conhecimentos mais sólidos quanto se apaixonassem por essa invenção humana.

Neste sentido, alguns avanços produzidos pelo trabalho dos pesquisadores integrantes da Sociedade Brasileira de Educação Matemática podem ser destacados, como, por exemplo, a incorporação das tendências em educação matemática aos indicadores de constituição dos currículos e aos livros didáticos de matemática. Entretanto, ainda há muito a fazer para que novas concepções a respeito da matemática, de seu ensino e sua aprendizagem reflitam em novas práticas pedagógicas.

A aproximação entre a criança e a matemática já existe no cotidiano, visto tratar-se de um conhecimento presente na constituição da história humana. Mas uma revisão na história do ensino dessa disciplina nos faz entender o que ocorreu para que um conhecimento que foi produzido pelo homem, a fim de resolver problemas do dia a dia e contribuir para a sobrevivência da espécie humana, tenha se tornado, na escola, um conhecimento sem relação com a vida. A afirmação de que existe uma aproximação histórica e social da criança com os conceitos matemáticos deriva da convivência diária com crianças, dentro e principalmente fora da escola: o agrupar, o classificar, o comparar, o quantificar, o observar formas, tamanhos, o identificar símbolos, o juntar, o retirar, o distribuir, são ações constantes na vida da criança e nas quais estão implícitos (ou explícitos) conceitos matemáticos. À escola compete, então, a partir da consideração dessas ações realizadas pelas crianças, em um processo de trabalho pedagógico organizado e intencional, contribuir com as crianças na sistematização dos conceitos presentes nas ações. 
Entre as publicações internacionais voltadas para essa temática, optamos em destacar aqui Ponte, Fonseca e Brunheira (2004) e Abrantes, Serrazina e Oliveira (1999). Em Ponte, Fonseca e Brunheira (2004) (2004) encontra-se uma discussão sobre matemática e atividade matemática:

\begin{abstract}
A Matemática é frequentemente encarada como uma ciência exata, pura, constituindo um corpo de conhecimentos construído dedutiva e cumulativamente, com rigor absoluto. Porém, diversos educadores matemáticos têm vindo a defender que é necessário ter em conta a prática dos matemáticos e olhar para a Matemática principalmente como uma atividade humana. Ou seja, para compreender a verdadeira natureza da Matemática é importante analisá-la numa perspectiva dinâmica, procurando compreender a forma como ela é construída e como evolui. (PONTE, FONSECA e BRUNHEIRA, 2004, p. 57-73)
\end{abstract}

Reforça-se, assim, a ideia de é preciso conhecer a matemática, a sua trajetória histórica, o processo de construção dos seus conceitos fundamentais e a relação de sua história com a história do homem. Ele que, em função de suas necessidades, criou instrumentos para solucionar problemas e, entre esses instrumentos, encontram-se construtos teóricos nas diferentes áreas de conhecimento, incluindo a matemática.

Abrantes, Serrazina e Oliveira (1999), em um documento dedicado à discussão sobre a matemática na Educação Básica, afirmam que:

\begin{abstract}
Aprender Matemática é um direito básico de todas as pessoas — em particular, de todas as crianças e jovens - e uma resposta a necessidades individuais e sociais. A Matemática faz parte dos currículos, ao longo de todos os anos da escolaridade obrigatória, por razões de natureza cultural, prática e cívica que têm a ver ao mesmo tempo com o desenvolvimento dos alunos enquanto indivíduos e membros da sociedade e com o progresso desta no seu conjunto. A matemática constitui um patrimônio cultural da humanidade e um modo de pensar. A sua apropriação é um direito de todos. Neste sentido, seria impensável que não se proporcionasse a todos a oportunidade de aprender matemática de um modo realmente significativo, do mesmo modo que seria inconcebível eliminar da escola básica a educação literária, científica ou artística. Isto implica que todas as crianças e jovens devem ter possibilidade de contatar, a um nível apropriado, com as ideias e os métodos fundamentais da matemática e de apreciar o seu valor e a sua natureza. (ABRANTES; SERRAZINA; OLIVEIRA, 1999, p. 15)
\end{abstract}

Os autores fazem referência à aprendizagem da matemática como um direito básico de todas as pessoas indistintamente. Novamente, encontram-se argumentos referentes a esse conhecimento que, além de atender às necessidades práticas do homem, é um patrimônio cultural e principalmente por esse motivo, do mesmo modo como se tem o direito de conhecer qualquer produção científica e literária, tem-se o direito de ter acesso ao conhecimento matemático. Reafirma-se a preocupação com a criança que, mesmo com diversificadas experiências matemáticas já vividas fora da escola, chega à escola e tem os contatos iniciais com a matemática escolar, no processo de alfabetização. 


\subsection{ALFABETIZAÇÃO MATEMÁTICA}

Essa pesquisa teve como participantes as alfabetizadoras, as coordenadoras pedagógicas, a gestora e as crianças dos anos iniciais do Ensino Fundamental. Assim, atentamos para a necessidade de refletir sobre as concepções de infância e de criança. Entendemos a infância como categoria social, em que a criança é um ser histórico, cultural e social de direitos, envolvida no meio em que vive. Em Pimentel (2012) vimos que:

\footnotetext{
Alguns autores da área da sociologia criticam versões do século passado que consideram a socialização a chave que a criança associal tornar-se um adulto socializado. Para a concepção de socialização como processo de fazer a criança virar um adulto, as marcas do tempo histórico ou do espaço social específico em que ela vive são apagadas, e predomina ainda uma visão evolucionista para a qual o lugar do adulto é o ponto de chegada imutável e desejado. Contudo, alguns autores defendem que a infância não deve ser vista como uma idade de transição (a não ser que todas as idades sejam abordadas dessa forma), mas um componente estrutural da sociedade que merece uma atenção própria. [...] A abordagem das crianças como atuantes na sociedade vem se traduzindo na perspectiva dos estudos da criança, de orientação socioantropológica, que buscam revelar o mundo cultural das crianças e compreendê-las como sujeitos socialmente capazes. (PIMENTEL, 2012, p. 21, grifo nosso)
}

A ampliação do Ensino Fundamental para nove anos convidou à construção de um trabalho pedagógico que estabeleça a interface entre a Educação Infantil e o Ensino Fundamental, de modo a assegurar a continuidade do desenvolvimento da criança e, ao mesmo tempo, propiciar formas de promover sua inserção em outra etapa da vida escolar: o Ensino Fundamental. Esse segmento da Educação Básica, principalmente os anos iniciais, pode ser visto como o fundamento de uma construção que se estenderá por vários anos, na perspectiva de permitir ao cidadão sua integração em diferentes práticas sociais e educacionais.

Com relação à educação matemática, é nessa fase que a criança constrói ou sistematiza os conhecimentos que lhe possibilita agir e tomar decisões em situações problemas do cotidiano. Ela cria uma base que servirá de referência na formação de conceitos matemáticos mais complexos em anos posteriores e, principalmente, amplia suas possibilidades de leitura do mundo.

Pensar nessa possibilidade implica em pensar no currículo de matemática e, neste sentido, atentamos para um importante documento - Elementos Conceituais e Metodológicos para Definição dos Direitos de Aprendizagem e Desenvolvimento do Ciclo de Alfabetização ( $1^{\circ}, 2^{o}$ e $3^{\circ}$ anos) do Ensino Fundamental (BRASIL, 2012) - que apresenta duas maneiras de compreender o termo alfabetização.

Inicialmente, pode-se pensar que em "um sentido stricto, alfabetização seria o processo de apropriação do sistema de escrita alfabético". Porém, entende-se ser necessário que a criança 
avance rumo a uma alfabetização em sentido lato e possa conhecer as práticas, os usos e as funções da leitura e da escrita e isso exigirá um trabalho com todas as áreas curriculares e em todo o processo do Ciclo de Alfabetização. E, dessa forma, coerente com o que afirma o documento, "a alfabetização em sentido lato se relaciona ao processo de letramento envolvendo as vivências culturais mais amplas" (BRASIL, 2012, p. 27).

O estudo do documento amplia o modo de pensar o Ciclo de Alfabetização. Destaca-se, por exemplo, a afirmação de que são, no mínimo, 600 dias letivos para esse ciclo que se constitui de 3 anos de escolaridade, dos 6 aos 8 anos de idade, o que teoricamente retira a ideia de que a alfabetização ocorre em um ano. Digo teoricamente, pois antes de realizar essa pesquisa e após sua realização é mais forte a percepção de que é necessário investir muito na formação do professor alfabetizador para que esse entendimento se efetive de fato.

No documento, expressa-se a intenção de:

Considerar a demanda advinda dos sistemas e redes de ensino, sem ferir a liberdade de organização conferida a estes, na direção deste Ministério apresentar elementos dos Direitos e Objetivos de Aprendizagem e Desenvolvimento para o Ensino Fundamental que os subsidiem e lhes possibilitem a definição de currículos para o Ciclo de Alfabetização ( $1^{\circ}$, $2^{\circ}$ e $3^{\circ}$ anos), $4^{\circ}$ e $5^{\circ}$ anos e anos finais $\left(7^{\circ}, 8^{\circ}\right.$ e $9^{\circ}$ anos) do Ensino Fundamental, que expressem os conteúdos básicos, relevantes, necessários e de significação social, em conformidade com a base nacional comum do currículo, bem como com a parte diversificada, como impõe a LDB, no Artigo 26. (BRASIL, 2012, p. 15)

E acrescenta-se que:

O foco inicial do debate curricular, para o Ensino Fundamental, abrange os Direitos e Objetivos de Aprendizagem e Desenvolvimento para o Ciclo de Alfabetização $\left(1^{\circ}, 2^{\circ}\right.$ e $3^{\circ}$ anos), em Linguagem (Língua Portuguesa, Educação Física e Arte); Matemática; Ciências Humanas (História e Geografia); Ciências da Natureza. As razões que levam esse Ministério a priorizar neste momento o Ciclo de Alfabetização estão relacionadas às ações elencadas, anteriormente, e aos dados sobre os índices de analfabetismo e de baixa proficiência dos estudantes brasileiros nas habilidades de leitura e escrita. (BRASIL, 2012, p. 15)

Observa-se que o documento fala em direitos e há toda uma discussão sobre o que significa ter direitos, a aprendizagem aparece como um direito. Vimos o Ciclo de Alfabetização colocado como prioridade. Existe, ainda, uma preocupação em não tratar o Ciclo de Alfabetização isolado em relação a toda a Educação Básica, mas, sim, como parte fundamental e integrada, inclusive com a necessária ressignificação dos Projetos Políticos Pedagógicos, com a mudança na forma de ver/implementar o currículo e a avaliação. Essas mudanças visam criar um ambiente formativo na sala de aula, retomar a relação com as famílias e, principalmente, redimensionar o papel do professor: 


\begin{abstract}
Trata-se de conceber um trabalho que não isole o Ciclo da Alfabetização, mas o considere parte integrante de um processo mais global que é a Educação Básica. Um trabalho que: (re)crie os Projetos Políticos Pedagógicos; atue interdisciplinarmente nos currículos; possibilite que o processo avaliativo cumpra seu papel diagnóstico e que se desvele em ações diversas, principalmente de apoio às crianças com dificuldades; altere, significativamente, os ambientes formativos; traga a ludicidade, a imaginação e propostas instigantes para o contexto pedagógico; dirija uma escuta atenta e qualificada às famílias em suas críticas, sugestões e necessidades; conceba os professores como sujeitos em seus ofícios de mestres, os quais são, portanto, atores históricos, sociais e culturais que cumpram o desígnio de garantir as aprendizagens de seus alunos no processo formativo de todos e de cada um. (BRASIL, 2012, p.19)
\end{abstract}

É interessante também atentar-se ao que o documento traz em relação ao compromisso da alfabetização com as diferentes áreas curriculares. Em um tópico dedicado a esse tema, vê-se uma referência à Lei 9.394, de 20 de dezembro de 1996, que em seu Art. 32 já explicita a formação que se propõe para os estudantes. E a Lei $\mathrm{n}^{\circ} 11.274$, de 06 de novembro de 2006, altera a redação dos Arts. 29, 30, 32 e 87 da Lei $\mathrm{n}^{-}$9.394, de 20 de dezembro de 1996, que estabelece as diretrizes e bases da educação nacional, dispondo sobre a duração de 9 (nove) anos para o ensino fundamental, com matrícula obrigatória a partir dos 6 (seis) anos de idade. Os objetivos do ensino fundamental visando à formação básica do cidadão seriam:

1. o desenvolvimento da capacidade de aprender, tendo como meios básicos o pleno domínio da leitura, da escrita e do cálculo;

2. a compreensão do ambiente natural e social, do sistema político, da tecnologia, das artes e dos valores em que se fundamenta a sociedade;

3. o desenvolvimento da capacidade de aprendizagem, tendo em vista a aquisição de conhecimentos e habilidades e a formação de atitudes e valores;

4. o fortalecimento dos vínculos de família, dos laços de solidariedade humana e de tolerância recíproca em que se assenta a vida social.

Ressalta-se que a referência à aprendizagem do cálculo aparece logo no primeiro objetivo. Infere-se daí a importância dada à matemática no currículo escolar. Mas, cabe observar que a matemática não se reduz ao cálculo e precisa ser vista de modo mais amplo, como já previam os Parâmetros Curriculares Nacionais (BRASIL,1997) ao propor a exploração dos pensamentos aritmético, geométrico, métrico, algébrico, estatístico, combinatório e probabilístico, desde os anos iniciais.

No primeiro parágrafo do Art. 14, da Resolução CNE/CEB 4/ 2010, consta a matemática como uma das áreas que compreende a base nacional comum do currículo da Educação Básica. Na continuidade do texto do documento Elementos Conceituais e Metodológicos para Definição dos Direitos de Aprendizagem e Desenvolvimento do Ciclo de Alfabetização (1 ${ }^{\circ}, 2^{\circ}$ e $3^{\circ}$ anos) do Ensino Fundamental encontram-se referências ao trabalho com essa área e coloca-se como objetivo do trabalho com a Matemática nas séries/anos iniciais: 
Dar oportunidade para que as crianças coloquem todos os tipos de objetos, eventos e ações em todas as espécies de relações, sendo importante que as atividades propostas sejam acompanhadas de jogos e de situações-problema e promovam a troca de ideias entre as crianças. Especialmente nesta área é fundamental o professor fazer perguntas às crianças para poder intervir e questionar a partir das suas lógicas. (BRASIL, 2012, p. 23)

As ideias expressas nesse objetivo são discutidas de modo mais específico quando são apresentados os Direitos de Aprendizagem na área de matemática ${ }^{10}$ e os eixos estruturantes: números e operações, grandezas e medidas, espaço e forma e tratamento da informação. Como nosso interesse é a alfabetização em matemática, analisamos junto às professoras alfabetizadoras os direitos de aprendizagem:

I. Utilizar caminhos próprios na construção do conhecimento matemático, como ciência e cultura construídas pelo homem, através dos tempos, em resposta a necessidades concretas e a desafios próprios dessa construção.

II. Reconhecer regularidades em diversas situações, de diversas naturezas, compará-las e estabelecer relações entre elas e as regularidades já conhecidas.

III. Perceber a importância da utilização de uma linguagem simbólica universal na representação e modelagem de situações matemáticas como forma de comunicação.

IV. Desenvolver o espírito investigativo, crítico e criativo, no contexto de situaçõesproblema, produzindo registros próprios e buscando diferentes estratégias de solução.

V. Fazer uso do cálculo mental, exato, aproximado e de estimativas. Utilizar as Tecnologias da Informação e Comunicação potencializando sua aplicação em diferentes situações. (BRASIL, 2012, p. $66-69$ )

É possível perceber que os Direitos de Aprendizagem na área de matemática, expostos acima, sintetizam algumas ideias discutidas até aqui, como: a matemática é atividade humana, é construção histórica; a observação de regularidades e a elaboração de uma linguagem simbólica são características próprias do processo histórico de construção do conhecimento matemático, que se constituiu em busca de solução a problemas e isso graças ao espírito investigativo e criativo próprio do ser humano. A criança tem naturalmente um espírito investigativo e criativo e tem direito a ter acesso à matemática nesta perspectiva de construção de caminhos.

Coerente com o que está proposto nesse documento, Fonseca $(2014$, p. 31) define que a alfabetização matemática preocupa-se com:

As diversificadas práticas de leitura e escrita que envolvem as crianças e nas quais as crianças se envolvem no contexto escolar e fora dele, refere-se ao trabalho pedagógico que contempla também relações com o espaço e as formas, processos de medição, registro e uso das medidas, bem como estratégias de produção, reunião, organização, registro, divulgação,

\footnotetext{
${ }^{10} \mathrm{O}$ documento Elementos Conceituais e Metodológicos para Definição dos Direitos de Aprendizagem e Desenvolvimento do Ciclo de Alfabetização (1 ${ }^{\circ}, 2^{\circ}$ e $3^{\circ}$ anos) do Ensino Fundamental dedica as páginas 59 a 83 a descrição pormenorizada dos Direitos de Aprendizagem na área de Matemática com a descrição de cada eixo estruturante: Números e Operações, Pensamento Algébrico, Espaço e Forma, Grandezas e Medidas e Tratamento da Informação.
} 
leitura e análise de informações, mobilizando procedimentos de identificação e isolamento de atributos, comparação, classificação e ordenação.

Mostra-se, assim, uma preocupação em não limitar o trabalho da alfabetização às técnicas operatórias, mas proporcionar a vivência de situações diversificadas que contemplem os conceitos e procedimentos que constituem os eixos estruturantes da área de matemática. Pesquisadores em educação matemática como, por exemplo, Smole (2001), investigam e propõem atividades em que a leitura e a escrita acontecem também nas aulas de matemática.

O estudo realizado por Danyluk (2002) foi uma de nossas referências, pois a autora, desenvolveu uma pesquisa sobre alfabetização matemática na escola. Ela a definiu como: "os atos de aprender a ler e a escrever a linguagem matemática usada nas primeiras séries da escolarização". Para ela, ser alfabetizado em matemática é: "entender o que se lê e escrever o que se entende a respeito das primeiras noções de aritmética, geometria e lógica” (DANYLUK, 2002, p.14).

Coerente com esses estudiosos, entendemos a alfabetização matemática como um processo de aprendizagem dos conceitos iniciais de matemática, relacionados a números, operações, grandezas, medidas, formas, localização, orientação, deslocamento, tratamento da informação e estimativa. Trata-se de um processo em que, no envolvimento com situações-problema, a criança constrói e mobiliza tais conceitos. Esse processo, como já dissemos, inicia-se fora do contexto escolar, continua, é aperfeiçoado e ampliado quando a criança ingressa na escola, seja na Educação Infantil ou no primeiro ano do Ensino Fundamental. Aprende-se dentro e fora da escola. Isso implica em aprender a linguagem matemática, conhecer os objetos matemáticos, propor, identificar e resolver situações-problema, comunicar as estratégias de solução e, principalmente, mobilizar os conceitos matemáticos em diferentes situações, tanto dentro quanto fora da escola.

Ao entender que o processo de alfabetização é processo de aprendizagem e que na escola a professora alfabetizadora assume a tarefa de ensinar os conteúdos matemáticos, é interessante destacar dois aspectos fundamentais que a professora deve dominar: (1) a elaboração das atividades de ensino tem relação direta com a compreensão do processo de aprendizagem dos conceitos; (2) a compreensão do processo de aprendizagem dos conceitos matemáticos implica tanto conhecimentos em psicologia e didática quanto o conhecimento dos conteúdos. 


\subsection{ENSINAR MATEMÁTICA NA ALFABETIZAÇÃO: A RELAÇÃO DO PROFESSOR COM O SABER}

É viável pensar que o ensinar toma como referência o que se entende por aprendizagem, uma vez que o ensinar implica em fazer aprender, ensinar algo a alguém. No nosso caso, ensinar matemática a crianças de seis a oito anos de idade. Essa é uma função do professor, no caso dos anos iniciais, da professora, que no Ciclo de Alfabetização é a alfabetizadora. Na tessitura da especificidade dessa função, a alfabetizadora irá prevalecer-se tanto de conhecimentos sobre a aprendizagem, quanto de conhecimentos sobre os conteúdos a ensinar. Com relação a esses últimos, não se pode ignorar os resultados de pesquisa, tal como a realizada por Ball (1991). Nela evidenciou-se que os conhecimentos matemáticos dos professores para ensinar podem influenciar positivamente o desempenho dos alunos.

E, de acordo com Nacarato, Mengali e Passos (2009), um desafio para a formação do professor que irá atuar nos anos iniciais é garantir, de forma integrada, a apropriação dos fundamentos da matemática e as questões pedagógicas. A relação do professor com o saber a ser ensinado nem sempre é harmoniosa e os seus conflitos conceituais refletem-se em sua proposta de trabalho. É, então, pertinente discutir brevemente a necessária relação do professor com o saber.

A leitura de Charlot (2005) ajuda-nos a entender melhor o conceito de saber em sua imbricação com o que é relativo ao ser humano. Ou seja, a busca do saber é que caracteriza o ser humano. No livro Relação com o saber, formação de professores e globalização: questões para a educação hoje, o autor reúne várias publicações referentes ao tema educação. Mais especificamente, ele trata da relação com o saber, mostrando ser essa relação fundamental para o processo de aprendizagem. Essa aprendizagem não se restringe à criança (na escola), mais ao homem que precisa conhecer para se tornar humano. E, em se tratando do processo de escolarização, pode-se adotar a perspectiva de Charlot (2005) tanto em relação ao vínculo entre o aluno e o saber, quanto ao saber docente, essencial no desenvolvimento profissional.

O autor esclarece que a expressão "relação com o saber" pode ser encontrada nos textos didáticos, de psicanalistas e de sociólogos desde os anos 1960 e 1970. Mas, mesmo permeando as discussões há muito tempo, nos anos 1980 e 1990 é que a noção de relação do sujeito com o saber é organizada em uma problemática e o conceito é trabalhado. O sujeito de que trata o autor:

Tem uma história e vive em um mundo humano, isto é, tem acesso à ordem do simbólico, à da lei e à da linguagem, constrói-se através dos processos de identificação e de desindentificação com o outro e tem uma atividade no mundo e sobre o mundo. [...] $\mathrm{O}$ sujeito se constrói pela apropriação de um patrimônio humano, pela mediação do outro, e a 
história do sujeito é também a das formas de atividade e de tipos de objetos suscetíveis de satisfazerem o desejo, de produzirem prazer, de fazerem sentido. (CHARLOT, 2005, p.38)

O modo de pensar o sujeito, como colocado pelo autor, deve nos remeter ao sujeito da aprendizagem científica, tecnológica e matemática que está em nossas escolas e ao qual, muitas vezes, não foi favorecido o acesso a relação com o saber, com o desejo de saber e com a vontade de aprender. Isso pode ter decorrido, em alguns casos, de práticas inadequadas que impedem o desenvolvimento do prazer em buscar o conhecimento.

Charlot (2005) afirma que, sob a ótica dos psicanalistas, o saber é objeto de desejo e ele chama a atenção para a questão de "como se passa do desejo de saber à vontade de saber, ao desejo de aprender" (CHARLOT, 2005, p. 37). A vivência em cursos de formação nos permitiu constatar em relação ao saber matemático que, em alguns casos, os licenciandos mostram, com suas atitudes, que perderam o desejo de saber. Sob esse aspecto, questiona-se: como um sujeito que não tem o desejo de aprender pode sentir-se animado a ensinar? Em algumas experiências positivas, foi possível perceber que a distância provocada pela falta de vontade em aprender pode ser revertida com a inserção do licenciando em situações problematizadoras, que tornem a busca de conhecimentos um desafio.

Numa ótica sociológica, Charlot (2005) analisa a relação do homem com a cultura e com a linguagem. Nessa relação, consideram-se três importantes aspectos: a compreensão da desigualdade social perante a escola passa necessariamente pela relação entre a linguagem, a cultura e o saber, pois esta relação estabelece vínculo entre o sistema escolar e a estrutura de relações de classe; existe uma possibilidade da escola adotar uma pedagogia que transforme a relação entre a linguagem, a cultura e o saber; se a escola insere-se numa sociedade desigual, necessário se faz mudar as relações de desigualdade existentes dentro do sistema escolar, pois, de outro modo, não será possível desenvolver uma pedagogia que contribua para a superação das desigualdades e para a promoção do sujeito como produtor de conhecimento.

Preocupado com essa problemática, Charlot (2005) procura afastar-se da sociologia das diferenças, da identificação das faltas e aproxima-se de uma forma de pesquisa em que faz uma forma diferenciada de leitura e tenta identificar e conceitualizar os processos através dos quais situações e práticas são construídos pelo sujeito. Metodologicamente, tal posicionamento implica em coletar e analisar dados que considerem o "sentido que o sujeito confere à sua história e a suas atividades" (CHARLOT, 2005, p.41).

Nosso intento foi trabalhar com as professoras, no sentido de desenvolver um olhar diferente voltado ao potencial da criança e ao seu próprio potencial de fazer ciência, experimentações, 
investigações, problematizações e de superar uma educação "bancária" que não oportunizou a construção de um espírito investigativo. Inclusive, conseguimos exercitar coletivamente a análise dos erros como possibilidade de explicitação de esquemas que dão sustentação ao processo de conceitualização matemática pela criança em processo de alfabetização.

Pesquisadores em educação matemática preocupam-se com esse problema e entre as pesquisas analisadas por Nacarato e Paiva (2006), encontra-se o trabalho de Manrique e André (2006) que tratam da relação do professor com o saber, na perspectiva de Charlot (2005).

As autoras preocuparam-se em estudar as relações do docente com os conhecimentos de sua área específica. Para obtenção de dados, acompanharam um processo de formação continuada, planejado e desenvolvido por um grupo de docentes e de pesquisadores da PUC-SP. As pesquisadoras buscaram usar instrumentos que fornecessem, com detalhes e de forma longitudinal, uma compreensão em profundidade de como se realizam as relações com o saber, no contexto de um processo de formação em Geometria. Perceberam, no início do trabalho, que alguns professores participantes apresentaram dificuldades para compreender alguns conteúdos matemáticos e para manusear materiais didáticos. É interessante notar que, à medida que o curso foi se desenvolvendo, essa relação mudou e a dinâmica de trabalho do professor também mudou (MANRIQUE; ANDRÉ, 2006). Da mesma forma, isso foi observado no grupo em que realizamos nossa pesquisa.

À discussão sobre a relação entre o professor e o saber, podem ser acrescentadas as ideias de Shulman (1986) que, em seu modelo de representação da base de conhecimentos, distingue: (i) conhecimento do conteúdo; (ii) conhecimento do conteúdo no ensino; (iii) conhecimento pedagógico. Especificamente, o conhecimento do conteúdo no ensino é subdividido entre três categorias: conhecimento sobre a matéria; conhecimento didático da matéria; conhecimento curricular da matéria.

Essas categorias podem direcionar o estudo sobre o conhecimento do professor voltado à compreensão e promoção da aprendizagem para o desenvolvimento da alfabetização em matemática, da mesma forma como procedeu Curi (2005) em pesquisa que teve como um dos objetivos investigar e examinar conhecimentos para ensinar a disciplina, bem como as crenças e atitudes que intervêm na formação de professores polivalentes. De acordo com a autora, ao tratar dos anos iniciais, tem-se o professor polivalente que “é responsável pela 'iniciação' das crianças nessa área de conhecimento, pela abordagem de conceitos e procedimentos importantes para a construção de seu pensamento matemático" (CURI, 2005, p.21). Por esse motivo, a formação desse professor tem sido um tema priorizado nas investigações na área de educação matemática. 
É inegável a prioridade dessa temática, pois a relação da criança com a matemática escolar começa, em muitos casos, com o seu ingresso no primeiro ano do ensino fundamental, etapa essencial do que hoje é chamado de ciclo da alfabetização ( $1^{\circ}$ ao $3^{\circ}$ ano). Entre outras questões, é importante indagar: Qual a relação da professora alfabetizadora com o saber matemático? Essa foi uma das indagações que esteve presente durante os estudos, as discussões e as reflexões na dinâmica de pesquisa-formação.

Pode-se ainda pensar em que consiste o saber do professor. Curi (2005) traz uma síntese sobre o conhecimento do professor sob a ótica das pesquisas em educação matemática. Entre os pesquisadores estudados por Curi (2005), destacam-se: Fiorentini, Nacarato e Pinto (1999), Serrazina (1999) e Ponte (1998). Fiorentini, Nacarato e Pinto (1999) consideram o saber docente como um saber reflexivo, plural e complexo, contextual, afetivo e cultural, que forma uma teia de saberes, mais ou menos coerentes, imbricados de saberes científicos e saberes práticos.

Serrazina (1999) afirma que o conhecimento do professor é dinâmico e continuamente alterado durante sua trajetória profissional pelas interações dele com o meio ambiente da sala de aula, com os alunos e com experiências profissionais suas e de colegas, o que permite categorizá-lo como um conhecimento de natureza situada. Ponte (1998), por sua vez, considera que o professor elabora e reelabora constantemente o seu conhecimento, em função do seu contexto de trabalho e das necessidades decorrentes das situações que vai enfrentando.

Curi (2005) traz autores que apresentam investigações que focalizam o conhecimento do conteúdo da disciplina "matemática", entre elas tem-se Ball (1991), que afirma que o conhecimento da matemática, para ser ensinada, envolve o conhecimento de conceitos, proposições e procedimentos matemáticos, o conhecimento da estrutura da matemática e de relações entre temas matemáticos, a natureza da matemática, sua organização interna, a compreensão dos princípios subjacentes aos procedimentos matemáticos e os significados em que se baseiam esses procedimentos, os conhecimentos do fazer matemática, incluindo a resolução de problemas e o discurso matemático. Há também Ponte (1998), que indica que os conhecimentos do professor devem incluir os objetos de ensino, ou seja, os conceitos definidos para a escolaridade na qual irá atuar, mas devem ir além, tanto no que se refere à profundidade desses conceitos como a sua historicidade, de modo a promover a articulação com outros conhecimentos e o tratamento didático, ampliando seu conhecimento da área.

Na realização dessa pesquisa, no contexto da escola, os estudos, as discussões, as reflexões e as problematizações permitiram que a relação da professora alfabetizadora com a matemática fosse bem evidenciada e foi possível notar a imbricação entre o conhecimento do conteúdo e a construção 
de propostas para ensinar esse conteúdo. Assim, podemos reafirmar que o ensinar na perspectiva de promover a aprendizagem implica no desenvolvimento de novas práxis pedagógicas que em muito se apoiam no conhecimento do conteúdo.

\subsection{PRÁXIS EM ALFABETIZAÇÃO MATEMÁTICA: A CONSTITUIÇÃO DE UMA PRÁXIS EMANCIPATÓRIA}

Entendemos a alfabetização matemática como um processo de aprendizagem dos conceitos iniciais em matemática, unido à produção de procedimentos pela criança envolvida em situações problemas, numa aproximação sistemática entre a criança e os conceitos matemáticos. Esse processo, iniciado em situações extraescolares, será aperfeiçoado e ampliado na escola. Nesse espaço institucional, encontramos um profissional - a professora alfabetizadora - que, para realizar o trabalho de alfabetizar, cria atividades de ensino que pretendem ser promotoras de aprendizagem. O trabalho de alfabetizar traduz-se em prática pedagógica. Essa expressão "prática pedagógica" pode referir-se a uma ação que envolve o ensinar e o aprender e ocorre em um contexto educativo, no espaço da escola ou em outros espaços sociais.

\subsubsection{Discussão do conceito de práxis sob a perspectiva de Vazquez}

Ao visualizar a possibilidade de constituir uma prática pedagógica que se traduza em uma práxis emancipatória em alfabetização matemática, buscamos entender alguns conceitos, como: prática pedagógica, emancipação e práxis. Perguntas que guiaram nosso estudo inicial, neste ponto foram: do que estou a falar quando uso a expressão "práxis emancipatória"? É possível a professora alfabetizadora constituir uma práxis emancipatória sem autonomia intelectual?

Vasquez (1990) adota o termo práxis e o diferencia do termo prática, pois este último remete ao significado de uso cotidiano que é o de uma atividade prática humana no sentido estritamente utilitário e pejorativo. $\mathrm{O}$ autor propõe o termo práxis para "designar uma atividade humana que produz objetos, mas sem aquele caráter estritamente utilitário que se infere do significado prático na linguagem comum" (VASQUEZ, 1990, p.4). Práxis seria uma "categoria central da filosofia que se concebe ela mesma não só como interpretação do mundo, mas também como guia de sua transformação" (VASQUEZ, 1990, p.5).

Na perspectiva de Vasquez (1990), faz-se necessário superar o ponto de vista imediato sobre a práxis e ascender a um ponto de vista objetivo e científico a respeito da atividade prática do 
homem, pois isso seria uma forma de unir conscientemente pensamento e ação. A condição de elevação de uma práxis espontânea ou reiterativa do dia a dia para uma práxis em um nível superior seria, para o autor, transcender os limites da consciência comum e atingir uma consciência filosófica da práxis. Entretanto, toma-se a atitude cotidiana como ponto de partida, porque:

O homem comum e corrente é um ser social e histórico; ou seja, encontra-se imbricado
numa rede de relações sociais e enraizado num determinado terreno histórico. Sua própria
cotidianidade está condicionada historicamente e socialmente, e o mesmo se pode dizer da
visão que tem da própria atividade prática. Sua consciência nutre-se igualmente de
aquisições de toda espécie: ideias, valores, juízos e preconceitos, etc. Nunca se enfrenta um
fato puro; ele está integrado numa determinada perspectiva ideológica, porque ele mesmo -
com sua cotidianidade histórica e socialmente condicionada - encontra-se em certa situação
histórica e social que engendra essa perspectiva. (VASQUEZ, 1990, p. 9)

A leitura dessa afirmativa nos projetou na escola, e nos vimos como seres sociais e históricos que, por sua vez, são imbricados numa rede de relações sociais e enraizados num determinado terreno histórico. A nossa visão sobre nossa atividade prática encontra-se, dessa forma, condicionada historicamente e socialmente. Resta-nos entender melhor essa rede de relações.

Continuamos em Vasquez (1990, p. 10) e ele esclarece que o homem comum e corrente se encontra numa relação direta e imediata com as coisas e nessa relação, mesmo consciente, não há uma distinção da prática como um objeto próprio. Decorre daí uma dificuldade de tomá-la em seu estado teórico, ou melhor, tomá-la como objeto do pensamento. A análise dos diferentes tipos de práxis, de acordo com o autor, nos daria indicativos para responder à pergunta: "como a consciência comum pode desprender-se de uma concepção ingênua e espontânea para elevar-se a uma consciência reflexiva?" (VASQUEZ, 1990, p. 11).

A resposta a essa pergunta nos interessa muito, pois, em nossas experiências com formação de professores que ensinam matemática, vimos que esse desprendimento se relaciona a fatores como maior conhecimento do conteúdo matemático e, ao mesmo tempo, mais consciência do significado da especificidade de sua profissão, que seria a sua prática pedagógica.

A princípio, Vasquez (1990, p. 208) afirma que "toda práxis é atividade, mas nem toda atividade é práxis" e que, para delimitar o conteúdo próprio da práxis e sua relação com outras atividades, distingue-se a práxis de outras atividades. Para tanto, se faz necessário delimitar a relação entre teoria e prática. Admite-se que não há uma oposição e, sim, uma diferença entre atividade teórica e atividade prática. Esta é uma ação efetiva sobre o mundo e provoca uma transformação real e aquela transforma nossa consciência dos fatos, nossas ideias sobre as coisas, mas não as próprias coisas. Uma não prescinde da outra. 
A unidade entre teoria e prática, para Vasquez (1990), para ser coerentemente formulada, supõe entender a prática como atividade objetiva e transformadora da realidade natural e social. Assim, a prática referida pelo autor se trata de uma atividade social transformadora. Pode-se ainda falar de uma mútua dependência entre teoria e prática ao atentar-se a ingredientes teóricos que integram a prática:

\footnotetext{
- um conhecimento da realidade que é objeto da transformação;

- um conhecimento dos meios e de sua utilização para fazer a transformação;

- um conhecimento da prática acumulada, em forma de teoria que sintetiza ou generaliza a atividade prática na esfera em que ela se realize, posto que o homem só pode transformar o mundo a partir de um determinado nível teórico, ou seja, inserindo sua práxis atual na história teórico-prática correspondente;

- uma atividade finalista, ou antecipação dos resultados objetivos que se pretendem atingir sob a forma de finalidades ou resultados prévios, ideais, com a particularidade de que essas finalidades, para que possam cumprir sua função prática, tem que corresponder a necessidades e condições reais, tem de tomar conta da consciência dos homens e contar com os meios adequados para a sua realização. (VASQUEZ, 1990, p. 240)
}

Ao ler essa afirmativa de Vasquez (1990), não há como não pensar na ação prática da professora que, de forma análoga à colocação do autor, integra esses mesmos elementos teóricos: a realidade, que é objeto de transformação em sua sala de aula; os meios que utilizará para fazer essa transformação; o que já foi feito por outros ou por ela mesma ao longo de sua história profissional; quais as suas finalidades e as condições objetivas de sua realização. Desse modo, a práxis é entendida como resultado da unidade entre teoria e prática.

Além do mais, uma práxis pode revelar-se em diferentes níveis, caracterizar-se como criadora ou reiterativa. Uma práxis reiterativa se dá em conformidade com uma lei previamente traçada. Sua execução reproduz múltiplos produtos que mostram características análogas e, por sua vez, numa práxis criadora, a criação não se adapta plenamente a uma lei previamente traçada e culmina num produto novo e único.

É possível, ainda, entender o papel da consciência no processo de constituição da práxis. Vasquez (1990) defende que a práxis criadora exige uma elevada atividade da consciência tanto ao traçar a finalidade quanto ao longo do processo. Uma rica e complexa criação exige uma atividade maior da consciência, pois a problematicidade, a improbabilidade do processo e a incerteza quanto ao resultado obrigam-na a intervir constantemente. É preciso pensar que a consciência também tem seu papel nos níveis mais baixos da práxis - mesmo com menor intervenção, ao automatizar-se a ação faz-se conscientemente.

A consciência poderia ser identificada também como consciência prática, que atua no início ou ao longo do processo prático, em íntima unidade com a plasmação ou a realização de seus objetivos, projetos ou esquemas dinâmicos e, como consciência da prática, além de se projetar e se 
plasmar, a consciência sabe de si mesma como consciência projetada, plasmada. Ela volta-se sobre si mesmo e sobre a atividade material em que plasma. Essa seria uma consciência da práxis e, assim, uma autoconsciência prática. Ainda em Vasquez (1990) vimos que, de acordo com o grau de manifestação dessa autoconsciência, seria possível distinguir mais dois níveis da atividade prática do homem: práxis espontânea, em que o grau de consciência seria baixo ou quase nulo, e a práxis reflexiva que teria um grau elevado de consciência.

Coerente com essas discussões teóricas, entendemos a práxis como uma ação transformadora da realidade. Quanto ao termo emancipação, ele aparece na discussão, realizada pelo autor, como correspondente a revolução. Após explanar sobre a relação entre filosofia e ação, Vasquez (1990) indica que a passagem da filosofia à realidade prescinde da adoção de uma teoria e do tipo de homens concretos que, ao adotá-la de forma crítica, transformariam essa teoria em ação. Essa crítica teria de ser radical, no sentido de ir à raiz do problema e, nesse sentido, a práxis resultaria dessa crítica radical e representaria uma revolução ou emancipação total do homem.

Uma condição essencial seria, nesse contexto, o elevado nível de consciência da situação em que se está envolvido. De novo lembra-se da atividade teórica imbricada à atividade prática. Essa atividade teórica, ao exigir esse elevado nível de consciência, a nosso ver, relaciona-se com a autonomia intelectual. Pensa-se na origem deste termo: Autonomia vem do grego e significa autogoverno, governar-se a si próprio. O que traduzimos de forma simples como "pensar com a própria cabeça", mas não de modo individual e, sim, de uma forma contextualizada ao considerar o contexto coletivo em que se está.

Neste estudo, também fomos atraídos pelo pensamento de Gramsci (2000), quando afirma que uma concepção do mundo criticamente coerente exige consciência da nossa historicidade, conhecimento da fase de desenvolvimento em que estamos e do fato de que nossa historicidade e nossas concepções podem estar contrapostas a outras concepções ou mesmo a elementos de outras concepções. Essa consciência tem a ver com a autocrítica e com a constituição da autonomia.

Contrapor a sua prática a outras práticas, ter consciência de sua ação e fazer autocrítica do trabalho que realiza em sala de aula é algo a ser continuamente realizado pelas professoras. Em nossa pesquisa, identificamos esse movimento: quanto mais conhecimento era produzido ou apropriado pela professora alfabetizadora, mais autonomia era demonstrada e um mais elevado grau de consciência de sua práxis era revelado, o que permitia evidenciar uma práxis reflexiva. 


\subsubsection{A constituição de uma práxis pedagógica em alfabetização matemática}

No campo da didática, encontramos em Veiga (1992) uma afirmação que situa a prática pedagógica como prática social: “A prática pedagógica é uma prática social orientada por objetivos, finalidades e conhecimentos, e inserida no contexto da prática social. A prática pedagógica é uma dimensão da prática social [...]” (VEIGA, 1992, p. 16). O conhecimento matemático é um conhecimento social, produzido em diversas situações sociais e, ao ser inserido no currículo escolar, ele é explorado em situações de ensino em que o professor objetiva aproximar as crianças dos conhecimentos sistematizados. Essa aproximação é mais bem-sucedida quando são adotadas propostas que oportunizem à criança produzir conhecimentos necessários para solucionar situações problemas que tenham significado em seu contexto social, tanto local quanto global. Assim, a prática pedagógica em matemática não pode deixar de ser uma dimensão da prática social.

Em outras publicações organizadas por Veiga $(2006,2010)$ encontramos os textos de Martins (2006) sobre as formas e práticas de trabalho dos professores, com foco na relação teoria e prática, e de Silva (2010), que analisou as práticas pedagógicas de quatro professoras da educação básica em processo de formação. Martins (2006) faz um resgate histórico do movimento dos educadores-sujeitos nos últimos 35 anos, com foco em suas práticas. Foram apontadas características que identificam o que norteou o trabalho do professor nos diferentes momentos dessa trajetória histórica. Vimos que, a cada momento, a relação entre a teoria e a prática mudou. Às vezes, predominou a prática pela prática, o aspecto técnico e instrumental; em outro momento, a teoria foi vista como guia da prática, sem que fosse estabelecida uma relação dialógica entre essas duas dimensões do trabalho pedagógico.

Entretanto, no princípio dos anos 1990, ocorreu uma mudança de paradigma decorrente dos movimentos sociais, pois se entende o homem em suas múltiplas determinações, em um determinado contexto histórico, envolvido em reações sociais, de modo a produzir sua sobrevivência. A educação é fundamental nesse processo e, por sua vez, escola compromete-se com ações transformadoras. Assim, “[...] a ênfase do processo desloca-se para a práxis social e a questão central está na relação dialética da compreensão-transformação" (MARTINS, 2006, p. 93).

Nessa concepção, a teoria deixa de ser entendida como verdade que vai guiar a ação prática e passa a ser vista como expressão de uma relação, de uma ação sobre a realidade, que pode indicar caminhos para novas práticas. Um modelo aberto de didática é delineado nesse momento, em busca de expressar a ação prática dos professores, de modo a abrir novos caminhos. Martins (2006) entende que ao problematizar e analisar, junto com os professores suas práticas, produz-se um novo 
conhecimento que irá apontar possíveis formas de novas práticas. A nossa pesquisa objetivou realizar essa ação.

O professor passa a ser visto como um sujeito que problematiza sua prática pedagógica, analisa, reflete, cria novas possibilidades de prática, produz conhecimento sobre essas práticas e o socializa. Isso exige que sejam buscadas interações mais coletivas e solidárias na escola. Nesse contexto em que se entende a relação pedagógica como relação social, constituem-se novas formas de relação com o conhecimento e a concepção de conhecimento em que a teoria é guia da ação é invertida: “A teoria passa a ser entendida como expressão da ação prática dos sujeitos [...]. A base do conhecimento é a ação prática que os homens realizam nas relações sociais, mediante instituições" (MARTINS, 2006, p. 97). Nesse sentido, tem-se que as formas de agir determinam as formas de pensar dos homens.

Assim, avançou-se na constituição de novas práticas pedagógicas em que a teoria torna-se a expressão da prática. Concorda-se com a afirmação da autora sobre a necessária ênfase na práxis social e na definição da relação dialética da compreensão-transformação como uma questão central do processo de ação-reflexão-ação.

Percebemos que as diferentes formas de práticas, evidenciadas ao longo de alguns períodos históricos, não são sequenciais, não se extingue uma e automaticamente adota-se outra. Diferentes perspectivas convivem e se materializam e, às vezes, em um mesmo espaço escolar, é possível identificar práticas pedagógicas embasadas em diferentes concepções da relação entre a teoria e prática.

Nesse cenário, observamos que, nem sempre, a ação do professor é uma ação refletida. Em algumas situações, a prática é essencialmente "prática", voltada ao que é imediato e mostra-se como uma prática imitativa, vinculada a regras, prescrições e ações repetitivas. Tal modo de agir foi identificado, por exemplo, em Silva (2010) que realizou um estudo no qual analisou as práticas pedagógicas de quatro professoras atuantes nos anos iniciais da educação básica e que vivenciaram a formação em exercício no curso de pedagogia.

No estudo de Silva (2010), as práticas observadas oscilavam da imitação à criação. Foi possível observar práticas conservadoras, práticas contraditórias e práticas criadoras. Ressalta-se que um mesmo sujeito professor, em contínuo processo de formação, pode apresentar, em diferentes contextos de sala de aula, diferentes formas de práticas. Firmar-se em uma prática criadora sem estar sujeito a oscilações, a dúvidas e contradições exige tempo e espaço de discussão coletiva.

Das indicações desses dois estudos, Martins (2006) e Silva (2010), é possível apreender que a práxis: a) é uma ação transformadora da realidade; b) é uma ação contextualizada, inserida em um 
contexto histórico; c) é uma ação guiada por intenções conscientes, que devem pautar-se na concepção de que o homem é um sujeito histórico que constrói o mundo nas relações sociais. Além disso, tem-se também que: i) a educação é um processo essencial nessa construção e; ii) a escola é uma instituição em que as ações se voltam para a formação humana. Esses entendimentos foram adotados como referências na realização deste trabalho de pesquisa, pois, como afirmamos na seção que tratou dos motivos que justificam a inserção da matemática no currículo escolar, a matemática é uma produção humana, faz parte dos bens científicos e culturais construídos pelo homem em sua ação transformadora. Desse modo, no processo de escolarização, essa área de conhecimento não pode ser explorada em uma prática pedagógica imitativa e, sim, em uma práxis criadora.

\subsubsection{Uma práxis emancipatória em alfabetização matemática}

Ao transpor essas considerações para a nossa pesquisa, inferimos que uma práxis pedagógica configura-se como uma ação que transforma o modo de trabalhar com o conhecimento matemático no contexto da sala de aula. No campo específico da educação matemática, desde a década de 1980, quando as tendências nessa área foram sistematizadas sob a forma de Parâmetros Curriculares Nacionais (1997), encontramos indicações para uma renovação da prática pedagógica em Matemática.

Entre os estudiosos na área de educação matemática, encontramos nos estudos da educadora e pesquisadora portuguesa Serrazina (2012) uma discussão sobre os elementos fundamentais para a constituição da prática pedagógica A tarefa de ensinar precisa ser aprendida pelo professor a fim de que ele possa delinear a sua práxis, mas essa aprendizagem não se dá apenas em um estudo teórico. Ela ocorre na experimentação, na reflexão e na problematização das práticas vivenciadas. Destacase o papel da planificação-ação- reflexão para a constituição desse conhecimento necessário para ensinar.

A planificação da atividade letiva, que entendemos como o planejar a sequência de ensino, e a reflexão sobre a prática, que irá tomar como referência o que foi planejado, são fundamentais para o desenvolvimento do conhecimento do professor. Uma sequência de ensino planificada será desenvolvida pelo professor e isso, de acordo com Serrazina (2012), exigirá:

(i) dar sentido e valor à Matemática, (ii) preocupar-se com a compreensão da Matemática, apostar na comunicação escrita e oral e sobretudo ouvir os alunos, (iii) valorizar os raciocínios dos alunos, olhando os processos desenvolvidos por estes, (iv) estruturar progressivamente o pensamento matemático, (v) considerar o erro e explorar as suas razões e (vi) reconhecer e aproveitar capacidades evidenciadas pelos seus alunos.

Mas também no pós-lecionação, ao refletir sobre o ensino da Matemática o professor tem de (i) interrogar-se sobre as aprendizagens matemáticas realizadas, ou não, pelos seus 
alunos, (ii) compreender a importância das decisões que tomou no decorrer da aula e quais as suas consequências nas aprendizagens dos alunos, (iii) reconhecer surpresas que eventualmente aconteceram na aula e tentar compreendê-las, (iv) identificar aspetos que dificultaram o seu ensinar, (v) assumir as suas fragilidades e procurar superá-las, e (vi) adquirir uma atitude profissional inquiridora e confiante. (SERRAZINA, 2012, p. 11-12)

Reforça-se, assim, que o pensar e planejar a aula, realizar a aula, oportunizar a comunicação oral e escrita, ouvir os alunos, reconhecer as suas capacidades e, ao mesmo tempo, não deixar esvair-se o conteúdo matemático, preocupar-se com a aprendizagem, com a constituição do pensamento matemático e ainda, após a aula, refletir, fazer uma autoavaliação, questionar-se, confrontar o que foi feito com o que foi planejado, são ações constitutivas da práxis pedagógica. Desse modo, é essencial discuti-las e aprendê-las nas experiências vividas durante a formação, seja ela inicial ou continuada.

Nessa mesma direção, destacamos as discussões realizadas pelos pesquisadores integrantes do Grupo de Estudos e Pesquisas em Educação matemática, coordenado pela professora Cármen Lúcia Brancaglion Passos, docente do Departamento de Teorias e Práticas Pedagógicas e do Programa de Pós-Graduação em Educação da UFSCar. O grupo promoveu, em 2011, o I Encontro de Educação matemática nos Anos Iniciais; em 2014, o II Encontro e em 2015 o III Encontro que reuniu professores dos anos iniciais e pesquisadores vinculados a programas de conhecimentos específicos sobre a matemática nos anos iniciais.

Concordamos que é importante que propostas de formação tomem por base esses estudos sobre a práxis pedagógica na área de matemática nos anos iniciais e experimentem outros formatos para as disciplinas que compõem o currículo do curso de formação inicial, destinadas à formação matemática do futuro professor. Acreditamos também que nos cursos de formação continuada é fundamental que o formador se preocupe em acompanhar pequenos grupos de professores de modo a estar junto no momento de pensar, planejar, realizar, avaliar.

Nacarato, Passos e Grando (BRASIL, 2014), ao tratarem da organização do trabalho pedagógico para a alfabetização matemática, que para nós representa uma das formas de expressão da práxis, trazem como um dos objetivos destacar a intencionalidade pedagógica como essencial ao processo de alfabetização. A transformação da prática é colocada em uma relação direta com a criação de um ambiente formativo em sala de aula:

No primeiro ciclo de alfabetização a sala de aula é um ambiente formativo que ocupa uma posição central no processo de alfabetização para as crianças do Ensino Fundamental. Além disso, deve-se considerar que o direito à alfabetização é um processo social e cultural mais amplo que inclui, além da aprendizagem da leitura e da escrita, a Alfabetização Matemática. (BRASIL, 2014, p.6) 
As autoras entendem que a sala de aula:

Deve se constituir como um espaço no qual as crianças ficarão imersas no processo de apropriação da leitura e da escrita da língua materna, bem como da linguagem matemática, com ampla exposição dos alunos aos materiais impressos que nos envolvem cotidianamente e possibilitam explicitar a função social da escrita. Veremos a importância da presença nesse espaço de materiais que remetam também para a função social da Matemática, como: gráficos, tabelas, informações numéricas diversas, etc. (BRASIL, 2014, p. 6)

E complementam que:

Na Alfabetização Matemática, esse movimento de trazer para as aulas as experiências vividas é imprescindível, pois é conhecendo e respeitando as culturas da infância, que o professor terá melhor condição para dar sequência às falas dos alunos. É nesse sentido que entendemos a sala de aula como uma comunidade de aprendizagem, ou seja, onde alunos e professores aprendem de forma colaborativa. (BRASIL, 2014, p. 6)

Para relacionar a práxis em alfabetização matemática com uma comunidade de aprendizagem compartilhada por professores e alunos, as autoras apoiam-se em Skovsmose (2000) e consideram que esse pode ser um cenário de investigação, como defendido pelo autor. Trata-se de constituir uma práxis, em sala de aula, em que seja possível aos alunos "matematizar, ou seja, formular, criticar e desenvolver maneiras matemáticas de entender o mundo" (BRASIL, 2014, p. $18)$.

Para tanto, ressaltam que o diálogo é fundamental e que os alunos devem participar do processo de investigação, e a ação de investigar é entendida como:

Investigar é experimentar coletivamente, ler, escrever e discutir matematicamente, levantar hipóteses, buscar indícios, observar regularidades, registrar resultados provisórios, compartilhar diferentes estratégias, variar procedimentos, construir argumentos matemáticos, como também ouvir os argumentos matemáticos dos colegas, buscar generalizar, conceituar. Professor e alunos participam desse movimento questionando, apresentando seu ponto de vista, oferecendo contraexemplos, argumentando, matematizando. (BRASIL, 2014, p.18)

Isso implicará em mudar de uma prática de ensino imitativa para uma práxis criadora, pois "permitir" aos alunos a investigação exigirá que seja estabelecida entre professores e alunos uma relação dialógica, como acrescentam Nacarato, Passos e Grando (2014):

A relação dialógica que necessita ser estabelecida em sala de aula envolve a compreensão de que em uma investigação todos se envolvem em uma relação horizontal, em que todos aprendem, professores e alunos, em que o que detém mais experiência ou mais conhecimento sobre um assunto contribui com o seu saber e ajuda os outros a avançar. (NACARATO; PASSOS; GRANDO, BRASIL, 2014, p. 19) 
Nesse sentido, nos apoiamos nos estudos do Grupo de Trabalho 1 (GT1) da SBEM, que direciona seu olhar aos anos iniciais do Ensino Fundamental, publicados em Guimarães e Borba (2009) para entender a práxis pedagógica em alfabetização matemática como uma ação intencional do professor, que cria situações de ensino dos conceitos iniciais de matemática, situações estas que podem se transformar em situações de aprendizagem para as crianças. Assim como defendem esses pesquisadores, acreditamos que a professora alfabetizadora, quando problematiza sua prática, produz conhecimentos que dão suporte a ação intencional que aproxima a criança das práticas de leitura, oralidade, escrita e resolução de situações problemas.

Ao considerar a possível constituição de uma práxis emancipatória em alfabetização matemática, ainda acrescentamos as indicações de Skovsmose (2001) que vão além da promoção do diálogo e das investigações na sala de aula. O autor discute a necessária adesão a uma concepção de uma educação matemática crítica, que corresponde a garantir as pessoas, professores e alunos, o direito de aprender matemática numa perspectiva ampla de apropriação e produção de conhecimentos nessa área, de modo a, de fato, exercer sua cidadania. E vemos que isso ocorre desde o início do processo de escolarização, desde a educação infantil e, principalmente, nos anos iniciais, especificamente, no que hoje é denominado Ciclo de Alfabetização $\left(1^{\circ}, 2^{\circ}, 3^{\circ}\right.$ anos do ensino fundamental), mesmo ao considerar que o processo de alfabetização não se encerra em três anos, mas que seus fundamentos se constituem nesse espaço de tempo.

Enfim, o desenvolvimento de novas práxis pedagógicas em matemática tem sido objeto de estudo de muitos pesquisadores em educação matemática, resta-nos indagar: como os resultados desses estudos implicam em mudanças na ação do professor? Como alimentam a reflexão e a problematização e auxiliam na constituição de novas práticas? Essas indagações nos impulsionaram a realizar esta pesquisa e nos animaram a estar na escola, junto com as professoras alfabetizadoras em busca de compreender as suas práticas e produzir conhecimentos que pudessem servir de referência para as próprias professoras.

\subsection{FORMAÇÃO DE PROFESSORES}

Este é um amplo campo de estudos e também de indefinições, pois várias são as abordagens quando se trata da formação de professores. Mais do que apresentar cada uma destas abordagens, nos interessamos em entender o que significa formar professores e, para tanto, focamos em estudos que mais trouxeram elementos teóricos para nos aproximar de uma possibilidade de formação da 
professora, dos anos iniciais do Ensino Fundamental, com autonomia para constituir a sua práxis como uma práxis emancipatória.

Embora haja muito discutido a respeito do tema por nós escolhido, sentimos necessidade de iniciar esse texto por três perguntas básicas: o que significa formação? Estamos a tratar da formação de qual profissional? Em que espaço esse profissional irá atuar? Situar o que iremos discutir tornase fundamental, pois o nosso foco de pesquisa é a práxis em alfabetização, especificamente na área de matemática. Nessa práxis encontram-se envolvidos as professoras alfabetizadoras, seus alunos e os conhecimentos matemáticos.

Formar pode ser sinônimo de constituir, compor, criar, instruir-se e também processo ou conjunto de procedimentos, de ações que dão forma. Além disso, pode-se pensar em formação humana como desenvolvimento humano e, especificamente, em formação profissional como a constituição de conhecimentos necessários ao exercício de uma profissão. No caso de nossa pesquisa, interessou-nos a formação do professor e, mais ainda, do professor que irá atuar nos anos iniciais do ensino fundamental, especificamente aquele que irá assumir a tarefa de ensinar as áreas de conhecimento que compõem o currículo dos anos iniciais e, entre elas, a área de matemática.

Dessa forma, a princípio, é importante destacar que a professora alfabetizadora é uma professora polivalente. Ao tratar dos anos iniciais, essa especificidade da professora tem de ser considerada. Nacarato, Mengali e Passos (2014), em publicação que teve como foco a matemática nos anos iniciais, logo no primeiro capítulo, dedicam uma seção à formação matemática da professora polivalente. As autoras evidenciam as deficiências formativas dessa profissional, tanto quando a formação ocorre em nível médio (modalidade Normal) quanto em nível de graduação (Normal Superior e Pedagogia).

Lembramos que a Lei de Diretrizes e Bases da Educação Nacional - LDB 9.394/96, em seu artigo 62, determina que a formação de docentes para atuar na educação básica deverá ser feita em nível superior, em curso de licenciatura, de graduação plena, em universidades e institutos superiores de educação. E, ainda, admite-se como formação mínima para o exercício do magistério na educação infantil e nas quatro primeiras séries do ensino fundamental, aquela oferecida em nível médio, na modalidade normal (BRASIL, 1996).

O curso em nível superior é o curso de Pedagogia e, de acordo com pesquisas como Gatti (2010), nesse curso não é constituída uma formação voltada para o ensino da Matemática que assegure ao professor os conhecimentos a ensinar aliados aos conhecimentos pedagógicos do que irá ensinar. Nesse sentido, tem-se também o estudo de Curi (2005), que analisou a formação da professora polivalente em instituições de ensino superior e afirma que, em sua maioria, os cursos de 
Pedagogia priorizam questões metodológicas e fazem uma formação distante das atuais tendências curriculares; isso resulta em não superar as crenças sobre a matemática, sua aprendizagem e seu ensino e não contribui numa sólida formação embasada nos conhecimentos matemáticos.

Entretanto, o que caracteriza a polivalência? Isso nos preocupou, pois, na escola vimos as professoras alfabetizadoras preocupadas em planejar aulas destinadas ao ensino de todas as disciplinas do currículo escolar. Encontramos em Cruz e Neto (2012) uma discussão sobre a polivalência como organização escolar docente, pois esta especificidade seria um elemento da profissionalidade de quem atua nos anos iniciais. Esses autores se referem à profissionalidade polivalente que, em seu entender, diferencia esse profissional e problematizam o fato de colocar-se de forma um tanto natural a implicação de um profissional ter de lecionar diversas áreas de conhecimento por ser professora dos anos iniciais.

Os autores intencionaram entender o que é próprio e como se configura a profissionalidade docente. Mostram uma preocupação com essa temática, justificada além de outros fatores, por existir uma indicação legal desde 2006 - as Diretrizes Curriculares do Curso de Pedagogia - que explicita uma clara intenção de formar professores/as para atuarem nos anos iniciais do ensino fundamental, o que implica diretamente na formação da professora polivalente.

O estudo de Cruz e Neto (2012) nos ajudou a, além de pensar nas lacunas conceituais de uma formação inicial que falha em seu objetivo básico de "preparar para o exercício de uma profissão", melhor compreender quem é essa profissional. Muitas vezes, na escola, as professoras preocupadas em reaprender a matemática afligiam-se e revelavam: "não tenho de estudar só isso". Nesse aspecto, os autores, após discutirem o significado do termo polivalência e nos chamarem a considerar o contexto do mundo do trabalho em que se tem no professor polivalente um profissional multifuncional, que se configura em meio as todas as implicações sociais e políticas, retornam o olhar para a formação e para a atuação desse professor dos anos iniciais com duas questões muito pertinentes: Como efetivar uma formação e atuação interdisciplinar, quando se tem uma frágil formação disciplinar? Sobre qual perspectiva de interdisciplinaridade se pautar?

Essas indagações, apesar de não constituírem o foco de nosso estudo, emergiam entre as ações de pesquisa na escola. E, nesse sentido, as discussões de Cruz e Neto (2012) também trouxeram esclarecimentos para melhor compreendermos as demandas que recaem sobre esse profissional que, às vezes, se vê impedido de mergulhar inteiramente em algumas propostas por já estar sobrecarregado com tantas atribuições.

Para sintetizar essa parte inicial, destacamos ainda alguns elementos que Cruz e Neto (2012) apresentaram referentes à especificidade da polivalência, após analisarem pontos comuns entre 
resultados de pesquisa que trataram de experiências brasileira, francesa e portuguesa. Eles constataram que: 1) o professor polivalente fica mais tempo com a criança e tem possibilidades de, além de atender às necessidades e interesses do aluno, perceber os conhecimentos de maneira integral - a polivalência poderia garantir uma formação integral do aluno; 2) há tensão entre dispor especialistas para lecionar as áreas de conhecimento do currículo da escolarização inicial ou defender a formação e atuação de um único professor para ensinar as diferentes áreas - nesse aspecto, na realidade brasileira, observa-se que um único professor tende a priorizar as áreas de língua portuguesa e matemática; 3) há tensão entre a polivalência oficial e a polivalência real, o que poderia talvez ser superada ao romper-se com o isolamento do professor e buscar formar equipes que trabalhariam para dar conta da diversidade de áreas de conhecimento.

Ao considerar essas especificidades que caracterizam a professora polivalente, que em nosso trabalho é a alfabetizadora, buscamos indicativos gerais sobre a formação do professor. Em quais princípios deveriam pautar-se uma formação que viesse, de fato, a contribuir com a profissionalização do professor?

\subsubsection{Indicativos gerais sobre a formação de professores}

Veiga e Silva (2010) ressaltam que a formação docente ocupa os debates educacionais de modo articulado à garantia da qualidade do ensino. Mas, ao tratar-se da formação de professores para a educação básica, há divergências em relação aos aspectos que devem ser contemplados nessa formação. Os debates têm como foco: a docência, o currículo, a relação entre ensino e aprendizagem e a articulação entre a teoria e a prática. Esses elementos, conhecidos pelos professores no curso de formação, aliados ao contato com a realidade da escola, poderiam contribuir para a compreensão do contexto da escola e da sala de aula.

Em um texto inicial do livro de Veiga e Silva (2010), Veiga e Viana (2010) discutem a formação a partir de duas questões: A formação de professores está voltada para qual contexto social? A formação de professores está voltada para qual escola básica? Essas autoras apresentam uma breve visão panorâmica do contexto social e afirmam que "as mudanças que sucederam no planeta afetaram e continuam a afetar os inúmeros subsistemas sociais, entre os quais a educação" (VEIGA; VIANA, 2010, p. 15). Um exemplo são as crises econômicas que impelem os países ricos a ditar medidas aos outros países e, em consequência das políticas, da "necessária" instalação de um Estado mínimo, as medidas reguladoras impactaram, na educação, em um modelo de gestão, de currículo e de escola que, a princípio, deve estar coerente com as características dessa política. 
A escola deveria, então, formar um trabalhador adequado a esse modelo e, mesmo sem ter se preparado para esse fim, essa é uma das principais exigências que o mercado global faz à escola. $\mathrm{O}$ aluno - futuro trabalhador - precisa enquadrar-se em um novo perfil e, para produzir esse trabalhador, o professor deve ter curso superior (não necessariamente na universidade), conhecer e adotar uma nova concepção de currículo, de avaliação, de gestão.

Nesse cenário, as autoras questionam a formação que, a partir dos anos 1990, resumiu-se a uma transmissão rápida de conhecimentos, com habilitação instantânea, com características de treinamento e adestramento, o conhecimento reduzido à informação técnico-instrumental e que resulta em um fazer acrítico e alienado, além de fortalecer relações não dialógicas (VEIGA; VIANA, 2010). As autoras descrevem quatro possíveis papéis que podem ser assumidos pelos professores, desde o que promove a educação bancária, o mero transmissor de conhecimento, o tecnólogo e, na pior das hipóteses, o professor desaparece e dá lugar aos recursos tecnológicos, o que significaria a extinção da profissão.

Ao negar esses modelos, pensa-se em uma proposta formativa que, de acordo com Veiga e Viana (2010), precisa ter clareza da concepção de formação e de seus princípios fundantes. Colocase a formação como um processo contínuo, vinculado à história de vida dos sujeitos e também como um processo de desenvolvimento humano.

Assim, será necessário pensar na formação humana como a ação de projetar-se, uma característica própria do humano, tem-se que buscar uma relação entre o pensamento e a ação, mediados pelas finalidades a que o homem se propõe. Isso implica, de acordo com as autoras, que a formação do professor, como projeto humano, deve adequar o real e o ideal, articular os interesses individuais e coletivos. Essas considerações reforçaram nosso desejo de estar na escola, um espaço coletivo, em que interesses individuais poderiam ser convergentes ou não, mas em comum as professoras têm o exercício da docência, que não é um dom, é algo a ser aprendido e o qual nós acreditávamos ser possível aprender junto, pesquisadora e professoras alfabetizadoras.

Veiga e Viana (2010) ainda observaram que a formação do professor pode se referir à formação pessoal e coletiva: a pessoal é de existência individual, espaço de iniciativa, inventividade e inovação e permeada pela intencionalidade, enquanto a formação coletiva é ampla e complexa. A complexidade reside no envolvimento de diferentes pessoas que, ao engajar-se no grupo, criam novas relações de poder, pois estão em um ambiente que, por ser humano, não está isento das tensões, conflitos, contradições, dilemas e sentimentos que contribuem para a aprendizagem do trabalho coletivo e implicam no processo de formação coletiva. 
Ainda em Veiga e Viana (2010), ressaltamos o espaço que as autoras abriram para reafirmar a imprescindibilidade do professor e discutir alguns aspectos importantes para a formação dos professores da educação básica. Para tanto, elas dialogaram com Cortesão (2002), Aguerrondo (2006a, 2006b) e Veiga (2007).

Em Cortesão (2002) foram destacados aspectos referentes à escola, tais como: o advento da escola de massas que trouxe à escola uma população bastante heterogênea; o ataque aos professores, realizado por alguns meios de comunicação; um mal-estar que vem crescendo tanto em professores quanto nos alunos; as situações de violência e de balbúrdia que estão presentes na escola; uma escola despreparada para a diversidade; uma escola que não se obriga a inovar-se. E, neste contexto adverso, afirma-se que se quer:

Um professor com capacidade crítica e inovadora, capaz de participar nos processos de tomada de decisão, de produção de conhecimento, de participação coletiva, consciente do significado da educação. Enfim, que seja um profissional formado para compreender o contexto social no qual se efetivará sua atividade docente. (VEIGA; VIANA, 2010, p.26)

Em acordo com Cortesão (2002), Veiga e Viana (2010) ressaltam que se pretende a formação de um professor que transite do conhecimento a respeito dos alunos e produza conhecimentos para os alunos. O professor deixaria de ser o tradutor/simplificador do conhecimento e assumiria o papel de "agente social interveniente, criador do processo educativo e social, ético no sentido de compreender as finalidades sociopolíticas e pedagógicas da educação, investigador e construtor de conhecimento" (VEIGA; VIANA, 2010, p.27).

Em Aguerrondo (2006a, 2006b) tem-se um modo interessante de olhar para os problemas da escola, pois é chamada a atenção para o fato de que acontecem, todos os dias, tanto coisas boas quanto ruins. Entre as insatisfações, Veiga e Viana (2010) destacam: a decepção dos pais com a qualidade do ensino; a insatisfação dos professores com as condições de trabalho e com a política de desvalorização docente; a desmotivação dos alunos. Além das insatisfações, é possível perceber as boas soluções em meio a tantas dificuldades.

Contudo, nesse contexto, as autoras apresentam a hipótese levantada por Aguerrondo (2006a, p.8, citada por VEIGA; VIANA, 2010): “o problema é que no mundo de mudanças, as transformações que temos na educação são superficiais, e a escola retoma sempre velhos modelos". De forma alguma se pode discordar desse fato, pois na escola, na dinâmica da pesquisa, vivenciamos essas oscilações. E, com os desafios postos, as autoras, ainda com base em Aguerrondo (2006), apontaram pontos fundamentais para mudar esse quadro, tais como o uso de uma rede de conhecimentos e interações, de modo a construir uma visão compartilhada e a disposição para experimentar as propostas de mudança, enfrentar os problemas e criar espaços de 
aprendizagem, de modo a propiciar a reflexão institucional, o que fortaleceria a prática. Tal prática, por sua vez, seria uma atividade inovadora, com um planejamento flexível que contemplaria, ao mesmo tempo, a tomada de decisão e a autonomia para atuar (VEIGA; VIANA, 2010). Esses indicativos nos ajudaram a visualizar uma forma de operacionalizar o nosso projeto de pesquisaformação.

A terceira autora estudada por Veiga e Viana (2010) foi Veiga (2007), que apresenta algumas características a serem consideradas ao tratar da formação do professor como agente social. Essas características foram a base para a nossa atuação como pesquisadora-formadora, quais sejam:

- defesa de uma política global que contemple desde a formação inicial e continuada até as condições de trabalho, salário, carreira e organização da categoria;

- luta pela construção coletiva de um projeto alternativo capaz de contribuir cada vez mais para o desenvolvimento de uma educação de qualidade para todos;

- procura pela compreensão da totalidade do processo de trabalho docente;

- construção de categorias de análise que permitam apreender as dimensões epistemológicas e metodológicas presentes na relação pedagógica;

- fortalecimento dos vínculos entre os saberes e a realidade social mais ampla, com a qual deve manter estreitas relações;

- reconhecimento do caráter profissional específico do professor;

- capacidade de planejar e gerir o processo didático como agente social, além de interferir na realidade;

- aspiração a um maior controle sobre o processo de trabalho pedagógico;

(VEIGA, 2007, p.31, citada por VEIGA; VIANA, 2010, p. 29)

Quanto ao primeiro ponto colocado pela autora, vimos a possibilidade de que, ao tomar consciência de seu valor profissional, como promotora da aprendizagem, formadora de pessoas, principalmente no caso da professora alfabetizadora, que é responsável por uma etapa essencial na formação do ser humano, essa profissional poderia atentar-se para o fato de que ela é a maior interessada na defesa de políticas que contemplem, desde a formação inicial e continuada até as condições de trabalho, salário, carreira e organização de sua categoria. Essa atitude se relaciona com o segundo ponto: a luta pela construção coletiva de um projeto alternativo. No nosso caso, delineamos uma alternativa de formação continuada em uma escola, que poderá servir de incentivo a outras escolas, a outras professoras e, desse modo, contribuir, cada vez mais, para o desenvolvimento de uma educação matemática de qualidade para todos.

Os quatro pontos seguintes, apontados por Veiga (2007), têm a ver com estudos sobre a profissão docente. Percebemos, às vezes, que os cursos de licenciatura discutem inúmeras temáticas e promovem leituras em diferentes áreas relacionadas à educação, mas não tomam como objeto de análise a profissão docente e ocorre, em alguns casos, do graduando concluir a licenciatura sem identificar-se com a profissão. Os dois últimos pontos poderiam ser atingidos quando a professora 
se engajar no espaço de discussão, estudos, problematizações e reflexões e, nesse espaço, pensar e experimentar novas práticas pedagógicas, de modo a integrar as suas aprendizagens a sua formação continuada.

Para compor essa discussão, também buscamos como referência um estudo em que estão relacionados o processo de reflexão coletiva e a formação de professores. Tratam-se dos estudos de Silva $(2008,2011)$ sobre a formação de professores numa perspectiva crítico-emancipatória. Neles, a formação de professores é pensada em um processo de reflexão coletiva, que deveria ter um tempo e espaço garantido dentro da instituição escolar.

\begin{abstract}
A formação inicial compõe, junto com a carreira, a jornada de trabalho e a remuneração, elementos indispensáveis de valorização profissional e constituição do profissionalismo. [...] A formação de professores é um processo contínuo de desenvolvimento profissional e político-social, que não se constrói em alguns anos de curso, nem mesmo pelo acúmulo de cursos, técnicas e conhecimentos, mas pela reflexão coletiva do trabalho, de sua direção, seus meios e fins, antes e durante a carreira profissional. [...] As mudanças no ensino e na sua qualidade dependem, além da formação inicial e continuada dos investimentos nas condições de trabalho: salários e carreira, tempo coletivo para reflexão no interior da escola, e outros fatores. (SILVA, 2011, p.15, grifo nosso)
\end{abstract}

Nessa perspectiva, a autora defende como princípios fundantes de um projeto de formação de professores: a) o trabalho, b) a relação teoria e prática, c) a pesquisa na/da formação e, d) a função docente. Ao tentar compreender essa perspectiva defendida por Silva (2011), serão aqui analisados esses quatro princípios.

Na discussão de um projeto de formação de professores, ao pensarmos no trabalho docente, não se pode deixar de considerar sua materialidade. Se, de fato, o ato de desvelar a realidade é um movimento que pode construir possibilidades de novas práticas, esse desvelamento deve ser realizado em espaços sociais mais amplos, entre os quais estão a comunidade escolar e as comunidades de pesquisa, pois ter a realidade desvelada numa posição individual e não posição da classe pode não provocar transformações. Nesse ponto, ao estar na escola, junto aos professores, consideramos que discutir a alfabetização matemática como um trabalho fundamental na escola básica permitiu que conseguíssemos chamar a alfabetizadora a reconhecer-se como uma profissional imprescindível à sociedade.

Desse modo, ao pensar a relação teoria e prática na formação de professores - a práxis deve-se considerar que teoria e prática são indissociáveis. Silva (2011, p. 22) propõe um conceito de práxis que "contém as dimensões do conhecer - da atividade teórica - e o de transformar - a atividade prática - numa indissociação entre ambas: teoria e prática”. Inferimos que uma prática transformadora só acontece se realmente houver uma unidade entre teoria e prática, pois a teoria 
torna possível conhecer a realidade e enxergar possibilidades de transformação. Por sua vez, é a prática que materializa essa transformação.

Nesse ponto, Silva (2011, p. 23) afirma que “a práxis não acontece na imediaticidade com modelos ou mesmo por meio de decretos legais, nem por teorias superficiais, uma vez que é o resultado de um processo histórico". E recorda Gramsci (2000) ao reforçar que é no interior desse processo histórico que se obtém a compreensão crítica de si mesmo. Isso exige, segundo os autores, uma luta de hegemonias políticas que deveria ocorrer primeiro no campo da ética, depois da política e, nesse processo, iria atingir uma elaboração superior. A autoconsciência em que teoria e prática estariam unificadas teria, assim, como primeira fase, a consciência política de fazer parte de uma força hegemônica.

Nesse ponto, pensamos que a consciência de fazer parte de uma determinada força hegemônica, a consciência política, de que fala Gramsci (2000), poderia vir a constituir-se nos espaços de reflexão coletiva, nas comunidades de estudo e de pesquisa, dentro da instituição escolar, em trabalhos realizados numa parceria entre os pesquisadores ligados à Universidade e entre grupos de pesquisa, alocados fora dela, integrando os professores de qualquer nível de escolaridade. Essa ação poderia contribuir com o professor na superação de uma visão individualista de seu trabalho, pois envolvido em sua rotina diária, em atividades inerentes ao trabalho na escola, na sala de aula, esse profissional esquece-se, às vezes, de sua condição de integrante de uma comunidade mais ampla. Acreditamos que a participação em estudos, discussões e reflexões ajude o professor na ampliação da consciência e no desenvolvimento da autoconsciência, em que, para Grasmci (2000), teoria e prática se unificam.

A respeito da pesquisa, Silva (2011) defende-a no sentido estrito relacionado ao campo da ciência. Para a autora, o professor pesquisador "será um pesquisador formado como qualquer pesquisador, rigidamente, nos fundamentos teórico-metodológicos da investigação cientifica" (SILVA, 2011, p. 29). Ao considerar relevante tal afirmação, torna-se necessário refletir sobre o espaço que é dado à pesquisa nos projetos de formação de professores.

Um quarto princípio fundante de um projeto de formação de professores, segundo Silva (2011), é a função docente, que é uma função social, é um exercício profissional e, ao mesmo tempo, humano. É preciso observar que a discussão da função social do professor, de acordo com Silva (2011), não acontece desconsiderando-se a totalidade da relação trabalho e educação, tampouco desconexa do contexto social. A autora afirma que:

O trabalho educativo é, portanto, a produção e reprodução do indivíduo humano e, ao mesmo tempo, a produção e reprodução do gênero humano. Tendo em vista a contradição presente no ato educativo, a função docente é vista aqui como exercício profissional e 
também humano; é próprio do trabalho docente produzir, de maneira intencional, necessidades cada vez mais elevadas em si próprio e em seus alunos, entrando em contato com o não cotidiano através da produção mais elevada pelo gênero no campo intelectual, não como um mero instrumento de adaptação, mas como uma condição imprescindível para mudança. (SILVA, 2011, p. 23-24)

Devemos considerar que a função social do professor se relaciona a da escola, que é uma instituição com um importante papel na sociedade. Nela o professor exerce a função de ensinar, não mais na ideia de passar informações, pois no contexto atual as informações estão disseminadas; seu trabalho transforma-se em possibilitar o conhecer: capacidade de síntese, de crítica, de estabelecer relações, entre outras funções intelectuais características do ser humano.

Tem-se, assim, a escola como lócus de produção e geração de conhecimento. E esse conhecimento, para Gramsci (2000), é um forte componente de elevação do ser humano tanto moral quanto intelectualmente. Esse processo é essencialmente formação. O professor, em espaços de reflexão coletiva, poderá tomar consciência de que a sua função, enquanto profissional responsável em lidar diariamente com o ser humano, tem que pautar-se em uma clara definição dos objetivos de seu trabalho. E, especificamente, neste estudo, aos objetivos de seu trabalho em educação matemática.

\subsubsection{Formação de professores que ensinam matemática}

A Sociedade Brasileira de Educação Matemática - SBEM, uma entidade de pesquisadores, tem se preocupado muito com o direcionamento das políticas públicas e com a implementação, nas escolas, de algumas orientações resultantes de estudos na área de educação matemática. Um pesquisador referência nessa área é o professor Muniz (2008), matemático e educador matemático, professor do curso de Pedagogia da Faculdade de Educação da Universidade de Brasília, formador de professores, realizador de pesquisa na escola com os professores. Entre as suas publicações, interessa-nos, neste ponto do texto, um artigo encomendado pelo GT19 - ANPED, que é o Grupo de Trabalho voltado para a educação matemática.

Muniz (2008) analisou quatro textos produzidos para o GT19 da ANPED - 31 a reunião, com o objetivo de aprofundar o tema das políticas públicas de formação de professores que ensinam matemática. Após analisar as produções, foram ressaltados alguns pontos fundamentais, como a necessidade de uma maior precisão conceitual acerca do termo políticas públicas que, para Muniz (2008), de acordo com Oliveira (2008), deve ser visto como um processo social e deve ser tomado “a partir da ideia da ação de diferentes sujeitos que desenvolvem suas atribuições, e cujo percurso 
segue uma lógica constituída em contextos mais abrangentes que aqueles concebidos estritamente no campo da educação" (MUNIZ, 2008, p. 4).

Nesse sentido, a formação de professores é entendida como uma vertente das políticas públicas e, a partir dessa compreensão, pode-se inferir que não se trata de uma determinação legal, mas de uma ação a ser realizada por todos os envolvidos. No caso das políticas públicas voltadas à formação do professor de matemática ou do professor que ensina matemática, nós todos educadores matemáticos - somos responsáveis tanto em construir o texto dos pareceres/documentos legais, quanto de fazê-los ter vida. Talvez isso se torne possível quando o pesquisador se inserir no contexto da escola e se colocar ao lado dos professores em um espaço de diálogo, de estudos e de reflexões.

Outro ponto que se pode destacar em Muniz (2008), é aquele relativo ao diferencial provocado pela maior alocação dos professores com formação em educação matemática nos cursos de licenciatura. Isso tem refletido na valorização das disciplinas pedagógicas nas licenciaturas em matemática, o que implica em melhor formação do licenciado e deveria chamar a atenção das políticas de formação para o perfil do formador. Do mesmo modo, isso também deveria garantir que o formador que atua na licenciatura em Pedagogia seja um educador matemático, um investigador da aprendizagem matemática em seus diferentes níveis e modalidades de ensino.

Nos estudos de Muniz (2008), também foram evidenciados graves problemas que permanecem na formação e implicam diretamente na qualidade do ensino. Entre os problemas presentes nos cursos de licenciatura em matemática, ainda permanece a disputa entre formar matemáticos ou formar professores, o que causa uma baixa estima no licenciando em relação a sua condição profissional. O licenciado em Matemática, provavelmente, será o professor formador em um curso de Pedagogia; assim, é importante ressaltar que a formação do professor de matemática deve estar ancorada no espaço e no contexto de resolução de problemas, associados à promoção da aprendizagem significativa da matemática na escola básica. Desse modo, o autor reafirma que a proposição de novos formatos de formação inicial e continuada tem conexão com o desenvolvimento de pesquisa em educação matemática.

Em especial, para esta pesquisa, destaco a análise do texto que trata especificamente da formação continuada de professores que ensinam matemática. Um dos pontos evidenciados por Muniz (2008), ao analisar o texto de Pirola e Moraes (2008), é a discussão do quadro atual da aprendizagem escolar da matemática, que retrata os baixos rendimentos, quando são avaliados os conceitos básicos da matemática. Ressalta-se que o pior é constatar que esse baixo rendimento é observado tanto no aluno quanto no professor. De fato, esse dado foi, e ainda é, constatado em 
nossas experiências de formação tanto inicial, nos cursos de licenciatura de Pedagogia e Matemática, quanto nos diversos cursos de aperfeiçoamento e atualização. Acrescenta-se que mesmo os professores com bom conhecimento dos conteúdos matemáticos, quando estão a ensinar apresentam grande lacuna quanto aos saberes didático-pedagógicos, assim como quanto àqueles de natureza psicológica.

É importante registrar a contribuição de Pirola e Moraes (2008) para a conceituação de formação continuada, como ressaltou Muniz (2008). A proposta dos autores é que se considere essa formação não como um espaço de preenchimento das lacunas da formação inicial e, sim, enxergá-la como:

Uma necessidade permanente e natural, reflexo da própria complexidade do fenômeno educativo, em especial, para aquele que ensina matemática. Afinal, o desenvolvimento da práxis implica a resolução de situações-problema associada à aprendizagem e ao desenvolvimento, à diversidade, à inclusão, à inter e multidisciplinaridade, dentre outros elementos que justificam, por si só, a permanente necessidade de desenvolvimento profissional e pessoal dos professores. (MUNIZ, 2008, p.18)

Ressalta-se a referência ao desenvolvimento da práxis em relação à resolução de situações problemas que são próprias do trabalho em sala de aula. Essas situações criam a necessidade de realizar estudos, que podem acontecer de forma individual ou coletiva, preferencialmente dentro da instituição escolar, em parceria com a Universidade. No caso específico da alfabetização matemática, a busca de compreender a complexidade do fenômeno da aprendizagem é que provoca a necessidade de uma formação continuada, pois é preciso, ao mesmo tempo, conhecer os conteúdos que integram essa área do saber, estudar o processo de aprendizagem desses conteúdos e criar situações promotoras dessa aprendizagem. A consciência deste fato impulsiona o professor a buscar o saber, como colocamos ao tratar da relação do professor com o saber na perspectiva de Charlot (2005) e remete-nos ao que diz Shulman (1986) sobre a construção de conhecimentos necessários à prática educativa.

Portanto, a partir das ideias destacadas por Muniz (2008), podemos tomar o Programa PróLetramento como exemplo de política pública, voltada para a formação continuada de professores, que apresentou resultados relevantes. Entre seus objetivos, destaco: 1) institucionalizar e fortalecer o trabalho coletivo como meio de reflexão teórica e construção da prática pedagógica, e; 2) desencadear uma dinâmica de interação entre os saberes pedagógicos produzidos pelos Centros de formação, no desenvolvimento da formação docente, e pelos professores dos sistemas de ensino, em sua prática docente. É relevante se observar que, nesses dois objetivos, temos a referência ao 
trabalho coletivo, à reflexão teórica e à interação entre os saberes produzidos na universidade e nas sociedades científicas, que podem promover a formação docente.

Ao relembrar do Programa, no qual atuei como coordenadora da área de Matemática e fui responsável por promover os estudos junto ao grupo de formadores que atuaram em algumas regiões do estado da Bahia, questiono, no momento atual, no ano de 2015, sobre a continuidade do referido Programa. Seus resultados estão registrados? De que forma e com quais critérios o Programa foi avaliado? Ele foi extinto ou ampliado? Essas são questões que poderiam ser objeto de investigação para nós pesquisadores vinculados à SBEM. Se essa política pública trouxe alguns resultados positivos, por que não avaliá-los e aperfeiçoar o trabalho, garantir a sua continuidade e buscar a superação do grave problema apontado por Savianni (2011) da descontinuidade das políticas públicas?

Como pesquisadora em educação matemática e professora formadora nos cursos de licenciatura, minha experiência permite ressaltar que quando os futuros professores participam das ações de extensão e de pesquisa, propostas por educadores matemáticos, aprendizagens mais significativas e produções mais próximas de práxis pedagógicas criadoras ocorrem. Para Muniz (2008), esse profissional - o educador matemático - tem um perfil adequado para:

\footnotetext{
Transformar a qualidade da formação, trazendo o eixo formador para os reais contextos da práxis. Os educadores matemáticos revelam possuir uma importante capacidade de reconfiguração dos projetos de formação, bem como suas implementações. Os estudantes de licenciatura e de pedagogia podem, não apenas por meio do ensino, mas também por ações de extensão contínuas, e de convivência com a pesquisa sob a orientação de docentes da área de educação matemática, desenvolver outras concepções acerca da matemática, seu valor formativo, cultural e social. (MUNIZ, 2008, p. 24)
}

Entende-se, assim, que o desenvolvimento de outras concepções acerca da matemática, seu valor formativo, cultural e social pode ser promovido nos cursos de formação de professores, tanto inicial quanto continuada, principalmente quando o formador é engajado nas pesquisas em educação matemática, pois assim seriam maiores as possibilidades de colocar a complexidade da sala de aula em discussão. Isso é imprescindível na formação do professor que irá ensinar ou ensina matemática em qualquer segmento da Educação básica. As políticas públicas direcionadas à formação do professor deveriam atentar-se, com maior rigor, a esse aspecto.

Além de Muniz (2008), nesta seção, educadores matemáticos como Pires (2003), Curi (2005), Pires e Curi (2008), Fiorentini (2003, 2005), Reis e Fiorentini (2007), Nacarato (2006, 2014) Ponte (1998), Serrazina (2003, 2008) e Ball (1991) contribuem para melhor compreender as perspectivas de formação de professores que ensinam matemática. Inicialmente, esclarece-se que entre os pesquisadores, atuantes nessa área, diferencia-se o professor de matemática do professor 
que ensina matemática nos anos iniciais. O primeiro é o licenciado em matemática que, às vezes, tem domínio do conteúdo, mas não tem a formação pedagógica; o segundo é o licenciado em pedagogia que tem formação para ensinar nos anos iniciais, mas não tem a formação em matemática e, na escola, essa disciplina é apenas mais uma entre as outras que compõem a matriz curricular.

Desperta nossa atenção o fato de Pires (2003), quando participou de uma mesa redonda no II SIPEM $^{11}$, com o tema Políticas de implementação curricular e formação de professores no Brasil, já ter afirmado que as relações entre as políticas de implementação curricular e a formação de professores precisavam estar na pauta das discussões. A autora alertava que faltavam ações de implementação curricular que fossem articuladas à formação do professor, pois as novas ideias não se transformariam em prática "num passe de mágica". Esse é um indicativo de que é imprescindível realizar pesquisas a fim de entender como os professores, ao participarem de programas de formação continuada que visam implementar mudanças curriculares, abrem-se a novas ideias e, ao compreendê-las, como eles as transformam em novas práticas.

No mesmo evento II SIPEM, Serrazina (2003), ao tratar da mesma temática afirmou que:

\begin{abstract}
Não basta mudar o currículo oficial para que a inovação surja. Alguns problemas que afetam as práticas curriculares no ensino básico prendem-se com: (i) uma visão do currículo como programa a dar mediado pelo guia escolar que o interpreta; (ii) uma tendência da escola para intervir por meio de práticas uniformes e homogêneas; (iii) uma visão do professor como executor acrítico e consumidor do currículo. Esta situação implica uma reflexão conjunta entre investigadores e professores, pois são estes que concretizam o currículo ao nível de sala de aula. (SERRAZINA, 2003, p. 10)
\end{abstract}

Essas são afirmações ainda válidas para o contexto atual e, ao reler Fiorentini (2003), percebe-se a mesma pertinência de suas afirmações sobre o tema formação de professores, sobretudo a formação de professores de matemática. Isso nos obriga a admitir que as mudanças são lentas e que, às vezes, o movimento individual parece insignificante. Os estudos, as discussões e os resultados de pesquisa não se traduzem em medidas efetivas e atingir uma convergência de ideias, de modo a imprimir aos documentos legais uma linha norteadora que atenda as diversas indicações dos diferentes grupos de pesquisa, é algo ainda a ser conseguido:

Nos últimos anos, o tema da formação de professores passou a ser dominante tanto em
encontros e congressos educacionais quanto em publicações de artigos e livros. Entretanto,
se olharmos com atenção ao que vem sendo dito e publicado, veremos que muito do que se
diz e escreve tem pouca sustentação investigativa e consistência teórica. A principal
mudança percebida acontece no âmbito do discurso. Hoje quase todos falam do
professor como profissional reflexivo, investigador de sua prática, produtor de saberes,
elemento-chave das inovações curriculares na escola e principal responsável pelo seu

\footnotetext{
${ }^{11}$ II SIPEM 2003 - Santos- São Paulo, Tema: A contribuição das pesquisas para a formação do professor de
} matemática. 
desenvolvimento profissional. Mas, ainda há pouca clareza e concordância sobre o significado desses termos. (FIORENTINI, 2003, p.9, grifo nosso)

É uma tarefa imprescindível, para nós educadores matemáticos, pensar em projetos de formação que impliquem em uma mudança que vá além do discurso. Chama a atenção também em Fiorentini (2003) o fato de, após mais de dez anos de discussões, ainda ser pertinente a colocação de Hargreaves (2001), citado por Fiorentini (2003), sobre a situação paradoxal da profissão professor, pois continuam de um lado a concepção e a valorização dos professores como "catalisadores da sociedade emergente" e de outro os impactos sofridos pelos professores em decorrência das políticas de gastos com a educação. Esse aspecto merece um estudo mais aprofundado, pois em 2003 a realidade de investimentos em educação era diferente do que existe hoje (2015), mas, conforme dados da OCDE, as condições de trabalho do professor, no Brasil, ainda são inadequadas e, em alguns casos, falta professor.

A área de educação matemática, entre outras, mesmo nesse cenário, é uma das que mais avançou em termos de políticas públicas nacionais. As ideias defendidas pelos educadores matemáticos foram incorporadas aos PCNs, ao PNLD, às avaliações externas, a Programas de Formação Continuada para a alfabetização como o Pró-Letramento e PNAIC. Fiorentini (2003) já atestava esse dado, dizendo que os educadores matemáticos têm buscado mudanças. Um exemplo dessa busca é o texto produzido por integrantes da SBM e da SBEM com diretrizes para a licenciatura em matemática. Parece-me que as mudanças ainda não se refletem nos resultados das avaliações em larga escala, o que implica a necessidade de divulgação, ampliação das pesquisas, inserção dos educadores matemáticos nos cursos de formação inicial, em Programas de Formação Continuada, em parceiras duradouras com as Secretarias Estaduais e Municipais de Educação e, principalmente, em trabalhos nas escolas.

Nacarato e Paiva (2006, p. 9-10) ao analisarem pesquisas sobre formação do professor que ensina matemática indicaram que "o grande desafio posto aos pesquisadores e formadores de professores é distinguir as fronteiras entre as metodologias de formação docente e a pesquisa sobre formação docente". Pode-se indagar: O que as pesquisas sobre formação docente têm dito às metodologias de formação docente? Como articular/integrar esses dois campos? Tem existido um diálogo entre os pesquisadores e os formuladores de programas de formação? E, nesse contexto, relembro que um dos pontos destacados por Muniz (2008) foi a constatação de que a proposição de novas e positivas formatações de formação inicial e continuada tem conexão com o desenvolvimento de pesquisa em educação matemática. 
E, ainda em Nacarato e Paiva (2006) sinalizaram que:

As pesquisas vêm destacando o protagonismo do professor no que diz respeito aos processos de desenvolvimento profissional e de formação: o professor tem tido voz e vem sendo ouvido; as pesquisas não têm sido sobre o professor, mas, principalmente, com o professor: há uma preocupação com o repertório de saberes do futuro profissional, considerando que esse não pode ser reduzido aos saberes do conteúdo matemático apenas; é enfatizada a importância da aprendizagem compartilhada e dos grupos colaborativos para o desenvolvimento profissional, dentre outros. (NACARATO; PAIVA, 2006, p. 24, grifo nosso)

No entanto, elas também apontam questões que ainda merecem atenção: a formação matemática do professor que atua na Educação Infantil e nas séries iniciais do Ensino Fundamental; as condições do trabalho docente e a formação do formador de professores.

No estudo de Reis e Fiorentini (2007), encontra-se uma discussão sobre a formação continuada como integrante do desenvolvimento profissional. Ela é vista como um processo que ocorre em múltiplas instâncias: na participação em congressos, palestras, cursos; ela acontece durante a leitura e o estudo de livros; na concepção e no desenvolvimento de projetos de pesquisa; durante a docência nos diferentes níveis de escolarização; nas trocas de experiências entre professores; ocorre também quando da observação, reflexão e análise da própria prática docente; em reflexões sobre experiências passadas e presentes, como estudante e como professor; entre muitas outras situações.

Concorda-se com Fiorentini (2007) que a formação continuada ocorre também quando o professor participa de congressos, palestras, cursos, durante a leitura e o estudo de livros, mas a realidade do professor, em muitos municípios brasileiros, mostra que essa participação é voluntária e depende, muitas vezes, das condições materiais do professor, que não tem como destinar uma parte de seu salário a inscrição em congressos, a cursos ou a compra de livros. Em muitos casos, os professores que se dispõem a essas atividades e buscam esses espaços formativos nem sempre são os que mais necessitam de formação. Dessa forma, uma proposta de constituição de espaços de estudos, reflexões e discussões na escola pode transformar esse espaço em local legítimo de formação e de transformação.

Curi e Pires (2008) apresentaram uma síntese de investigações a respeito da formação de professores que ensinam matemática. Elas ressaltaram que houve uma disseminação de teorias e conceitos, formulação de princípios e divulgação de trabalhos de diferentes países que realizam investigações centradas no professor em busca de saber: "o que os professores conhecem?”; “que conhecimento é essencial para o ensino?"; “quem produz conhecimento sobre o ensino?”; “como se formam os professores?” (CURI; PIRES, 2008, p. 153). Para as autoras, esse expressivo interesse 
justifica-se pelo fato de o professor passar a ser visto como um profissional que realiza reflexões, que pensa e produz conhecimentos. Essa mudança no modo de ver o professor impulsiona os pesquisadores a tomar a formação como objeto de investigação.

Nessa síntese, Curi e Pires (2008) retomaram algumas pesquisas internacionais sobre formação de professores. Elas destacaram entre os pesquisadores Ponte (1998), Ball (1991) e Serrazina (2001), que há muito contribuem com os pesquisadores nacionais e ainda continuam a dar suporte teórico aos estudos nessa área. Desse modo, passamos a relembrar algumas ideias fundamentais defendidas por esses três pesquisadores.

Para Serrazina (2001), o conhecimento necessário para ensinar matemática inclui a compreensão de ideias fundamentais da matemática e seu papel no mundo atual. E a formação deveria contribuir para o desenvolvimento da autonomia e essa resultaria da ampliação do conhecimento sobre a matemática, sobre o aprender e ensinar matemática. Ressaltamos que o conhecimento sobre o aprender e ensinar refere-se à compreensão da aprendizagem das crianças e à constituição do conhecimento matemático para ensinar. A formação, nessa perspectiva, deveria dar conta de construir esses conhecimentos.

Ball (1991), desenvolve estudos sobre o conhecimento que os professores dos anos iniciais têm sobre a matemática que irão ensinar. Para a pesquisadora, é necessário que o professor tenha conhecimentos "de e sobre" matemática. O conhecimento de matemática envolve conceitos, proposições e procedimentos matemáticos, o conhecimento da estrutura da matemática e de relações entre seus temas. O conhecimento sobre a matemática refere-se a conhecer a sua natureza, sua organização interna, os princípios subjacentes aos procedimentos, os significados desses procedimentos, e ainda conhecer o fazer matemática em que está incluído resolver problemas e compreender o discurso matemático.

Ponte (1998) que analisa e diferencia os conceitos de formação e desenvolvimento profissional e aponta que a formação é entendida, às vezes, de modo equivocado, como apenas a realização de cursos pontuais. No entanto, para o autor, essa visão sobre a formação pode ser mudada:

\footnotetext{
A formação pode ser encarada de modo mais amplo do que é habitual, não necessariamente subordinada a uma lógica de transmissão de um conjunto de conhecimentos. Na realidade, não há qualquer incompatibilidade entre as ideias de formação e de desenvolvimento profissional. A formação pode ser perspectivada de modo a favorecer o desenvolvimento profissional do professor, do mesmo modo que pode, através do seu "currículo escondido", contribuir para lhe reduzir a criatividade, a autoconfiança, a autonomia e o sentido de responsabilidade profissional. O professor que se quer desenvolver plenamente tem toda a vantagem em tirar partido das oportunidades de formação que correspondam às suas necessidades e objetivos. (PONTE, 1998, p. 191)
} 
Na perspectiva de Ponte (1998), o desenvolvimento profissional ocorre por meio de múltiplas formas, que incluem cursos, mas também atividades como os projetos, as trocas de experiências, as leituras, as reflexões etc. Nesse processo, tem-se um movimento de dentro para fora, cabendo ao professor tomar as decisões fundamentais, relativas às questões que quer considerar, aos projetos que quer empreender e ao modo como os quer executar. Implica o professor como um todo, em seus aspectos cognitivos, afetivos e relacionais e tende a considerar a teoria e a prática de uma forma interligada (PONTE, 1998).

E quanto aos conhecimentos, as atitudes e os valores que seriam próprios do professor de Matemática, Ponte (1998) defende que, para exercer adequadamente a sua atividade profissional, é imprescindível ao professor:

(a) ter bons conhecimentos e uma boa relação com a Matemática, (b) conhecer em profundidade o currículo e ser capaz de o recriar de acordo com a sua situação de trabalho, (c) conhecer o aluno e a aprendizagem, (d) dominar os processos de instrução, os diversos métodos e técnicas, relacionando-os com os objetivos e conteúdos curriculares, (e) conhecer bem o seu contexto de trabalho, nomeadamente a escola e o sistema educativo e (f) conhecer-se a si mesmo como profissional. (PONTE, 1998, p.189-195)

Mesmo ao apontar esses conhecimentos, o autor pondera que não é um somatório de conhecimentos que torna o professor preparado profissionalmente, pois esse profissional vai tomar decisões sobre pressão em sua prática educativa e, nesse contexto, serão exigidas competências na relação teoria e prática. Vimos, assim, que muito ainda precisa ser estudado em relação a essas questões e, especificamente, nos interessa saber sobre a formação da alfabetizadora em matemática.

\subsubsection{Formação da professora alfabetizadora em matemática}

Ao compreender o processo de alfabetização matemática como um processo de aprendizagem, que acontece em todos os espaços de convivência da criança, e ao concordar que para ter acesso aos conhecimentos culturalmente construídos e acumulados pela humanidade a criança deve relacionar-se com os atores sociais presentes em seu contexto histórico-cultural, percebe-se a escola como uma das instituições sociais que oferece oportunidades para isso. E, na escola, vê-se o professor como mais um dos responsáveis em criar situações em que a criança se aproprie dos conhecimentos em diferentes áreas, inclusive em matemática, em um processo contínuo que, nesse espaço, tem como marco inicial, além da educação infantil, o ciclo de alfabetização. 
Lembramos que no início da discussão sobre formação de professores, atentamos para a formação da professora polivalente que, em nosso trabalho, é a professora alfabetizadora. Ao se pensar no trabalho de alfabetizar, questiona-se: Quem forma o professor alfabetizador? E, principalmente, quem forma o professor alfabetizador na área de matemática?

Em nossa pesquisa, essa foi uma questão fundamental. O entendimento inicial de que esta formação não tem um espaço diferenciado, específico, foi reforçado. Essa formação continua a ocorrer de modo genérico nos cursos de formação inicial - magistério e/ou licenciatura em Pedagogia. E é nesse curso que, ainda, se espera sejam construídos os conhecimentos, tal como assinala Serrazina (2012):

O professor que ensina Matemática no ciclo de alfabetização necessita ter conhecimento do currículo de Matemática com o qual tem que trabalhar, precisa "identificar a Matemática essencial e pertinente" a ser ensinada aos seus alunos em cada ano, tomando como referência o ano anterior e o posterior vivido pelo aluno. Além disso, compete a ele "selecionar/adaptar tarefas com critério", escolher os recursos e pensar em estratégias da aula, "não esquecendo o nível etário dos alunos com quem está a trabalhar". (SERRAZINA, 2012, p. 273 apud NACARATO; PASSOS; GRANDO, 2014, p. 8)

Concorda-se com a autora sobre ser necessário que o professor tenha esses conhecimentos. Porém, resultados de pesquisa mostram que essa não é a realidade atual em nosso país. Bernadete Gatti (2010) toma por base os relatórios de pesquisa de 2008 e 2009 e aborda a formação de professores no Brasil. Ela apresenta dados que nos interessam por referirem-se às características dos cursos formadores de professores e aos currículos e ementas de licenciaturas em Pedagogia. Os dados sobre a formação profissional específica (porque, o que e como ensinar) e sobre a abordagem dos conteúdos das disciplinas a serem ensinadas na educação básica despertam preocupações.

Gatti (2010) afirma que o conjunto amostral do estudo aponta uma boa representatividade, pois foi composto por 71 cursos de licenciatura presenciais em Pedagogia, distribuídos em todo o país. E, após um mapeamento de propostas curriculares desses cursos, em diversos tipos de instituições de ensino superior que os oferecem, foram listadas 3.513 disciplinas (3.107 obrigatórias e 406 optativas) e estas foram agrupadas, através das ementas, a fim de ter mais clareza do que se propõe como formação inicial de professores nos currículos dos cursos de Pedagogia.

Para nosso estudo, chamaram atenção os dados que mostram que o grupo de disciplinas "Didáticas Específicas, Metodologias e Práticas de Ensino" (o “como" ensinar) representa 20,7\% do conjunto, e apenas 7,5\% das disciplinas são destinadas aos conteúdos a serem ensinados nas séries iniciais do ensino fundamental, ou seja, ao "o que" ensinar. Isso, segundo a autora, pode ser interpretado como uma evidência de que os conteúdos específicos das disciplinas a serem 
ministradas em sala de aula não são objeto dos cursos de formação inicial do professor, interpretação com a qual concordamos.

Após explorar dados relativos às disciplinas que se propõem a embasar teoricamente o Pedagogo em outras áreas de conhecimento e as disciplinas que tratam de questões ligadas à profissionalização mais específica do professor, Gatti (2010) refere-se a uma formação "panorâmica", pois é genérica. A autora questiona se essa formação, do modo como se apresenta, seria suficiente para que o futuro professor esteja preparado para planejar, ministrar e avaliar atividades de ensino para os anos iniciais do ensino fundamental e para a educação infantil. Para ela, há a constatação de uma "insuficiência formativa" para o desenvolvimento desse trabalho.

Na síntese de resultados feita por Gatti (2010), preocuparam-nos as afirmações referentes à formação profissional específica, que entendemos iria oportunizar ao professor em formação construir bases para sua atuação em sala de aula. Quando se constata que nestas disciplinas predominam os referenciais teóricos em poucos casos associados às práticas educacionais, retomamos a questão: Quem forma o alfabetizador? E acrescentamos: em que momento do curso de formação inicial esse futuro profissional estuda a especificidade deste trabalho? Além disso, entre os pontos destacados por Gatti (2010), atenta-se ao fato dos conteúdos das disciplinas a serem ensinadas na Educação Básica, entre elas a alfabetização, aparecerem apenas esporadicamente nos cursos de formação e, na grande maioria dos cursos analisados, estes conteúdos são abordados de forma genérica ou superficial e com pouca ou nenhuma associação com as práticas docentes.

Temos, então, dois aspectos a considerar: 1) a abordagem superficial ou inexistente dos conteúdos específicos das áreas de conhecimento, que compõem o currículo dos anos iniciais do ensino fundamental, e; 2) quando estes conteúdos são abordados, não há uma preocupação em associá-los às práticas docentes. Nesse cenário descrito e analisado por Gatti (2010), a constatação da fragilidade na abordagem dos conteúdos e na associação destes conteúdos às práticas docentes, nos leva a indagar, tomando como referência os estudos de Shulman (1986), em que momento da formação inicial o futuro professor constrói os conhecimentos defendidos pelo autor como essenciais para a atuação docente? Isto é, quando ele tem acesso a conhecimentos como: o conhecimento do conteúdo da disciplina; o conhecimento didático do conteúdo da disciplina; o conhecimento do currículo.

Neste ponto, voltamos aos estudos de Curi (2005), já citados neste texto, em que a autora analisou a formação do professor dos anos iniciais no curso de Pedagogia. Ela nos ajudou a caracterizar e a compreender a formação desse professor para ensinar matemática nesse segmento da Educação Básica. Após estudar documentos elaborados por órgãos normativos e instituições 
formadoras e analisar grades curriculares e ementas de algumas instituições formadoras, Curi (2005) indicou que em algumas propostas de cursos os futuros professores concluem sua formação inicial sem conhecimentos de conteúdos matemáticos com os quais irão trabalhar e essa lacuna está tanto nos conceitos quanto nos procedimentos. A autora também apontou que há falhas na aprendizagem da própria linguagem matemática que utilizarão em sua prática docente.

Entendemos que o professor alfabetizador está incluído no conjunto de professores dos anos iniciais, mas ao considerar as especificidades da alfabetização, do início do processo de aproximação entre a criança e a escola, da construção dos conceitos iniciais, interessam-nos entender quais são os conhecimentos que o professor que ensina matemática, nos anos iniciais, precisa ter para assumir e dar conta da complexidade desse trabalho.

Oliveira e Oliveira (2013), em uma das publicações do XI ENEM, apresentaram uma análise de 38 trabalhos entre dissertações e teses defendidas entre 2005 e 2010 que examinaram aspectos relacionados à formação inicial de professores que ensinariam matemática nos anos iniciais. Após o estudo, foram definidas sete categorias de análises, entre estas destacamos duas: (1) a matemática e o curso de formação em si e (2) a construção de saberes para o ensino de matemática.

Na categoria - a matemática e o curso de formação em si - as autoras incluíram os trabalhos que se voltaram para propostas de formação, ementários, discussões curriculares e comparação entre as diferentes instâncias de formação. Elas confirmaram o que Curi (2005) e Gatti (2010) já haviam constatado sobre as lacunas no curso de formação inicial em relação à formação para ensinar matemática. Nesse ponto, Oliveira e Oliveira (2013) foram enfáticas ao afirmarem que já está razoavelmente delineado o perfil dos cursos que estão sendo oferecidos atualmente, no Brasil, e como os resultados de pesquisa sobre este aspecto são convergentes, outros trabalhos com o mesmo objetivo podem não trazer novos conhecimentos.

$\mathrm{Na}$ categoria - a construção de saberes para o ensino de matemática - foram incluídos trabalhos que se direcionam para o desenvolvimento de saberes docentes nos cursos de formação inicial, de forma geral, em disciplinas específicas para o ensino de matemática (exceto o estágio), levando-se em conta a prática pedagógica nos anos iniciais, em matemática, e também incluindo propostas de atividades extracurriculares com futuros professores. Os resultados apontaram que as deficiências em conteúdo, apresentadas pelos ingressantes no curso de Pedagogia, não estão sendo superadas pela(s) disciplina(s) voltada(s) à formação matemática - em alguns cursos oferece-se apenas uma disciplina obrigatória. Os aspectos metodológicos continuam sendo priorizados e o futuro professor não se apropria dos conceitos fundamentais de modo a produzir conhecimentos necessários para ensinar. Além desse aspecto, foi evidenciado que as disciplinas teóricas são 
distantes da realidade da escola de Educação Básica. As autoras concluem, nessa categoria, que pesquisas sobre como tem ocorrido a formação matemática dos professores já existem, mas seria necessário estudar formas de trabalhar os conteúdos matemáticos específicos na formação inicial dos professores dos anos iniciais, a fim de propor estratégias de formação.

É interessante relembrar a afirmação de Curi (2005) sobre a prioridade de investigar a formação do professor que ensina matemática nos anos iniciais, pois esse professor polivalente é: “responsável pela 'iniciação' das crianças nessa área de conhecimento, pela abordagem de conceitos e procedimentos importantes para a construção de seu pensamento matemático" (CURI, 2005, p. 21). E essa iniciação ocorre, especificamente, no que atualmente é concebido como ciclo de alfabetização - $1^{\circ}, 2^{\circ}$ e $3^{\circ}$ ano do Ensino Fundamental. Reforça-se, então, o desafio: estudar e propor estratégias de formação para que, na formação inicial, o futuro professor possa trabalhar os conteúdos matemáticos específicos dos anos iniciais, aprendendo a ensiná-los.

Ao realizarmos uma busca nas matrizes curriculares de cursos de licenciatura em pedagogia, oferecidos em instituições públicas e particulares no município em que foi realizada a pesquisa, constatamos que, no curso oferecido pela instituição mais representativa da região, existe uma disciplina denominada Fundamentos e Prática de Alfabetização, com carga horária que varia entre 60 e 90 horas. Porém, verificou-se que nesse componente curricular tanto pode ocorrer uma discussão genérica sobre alfabetização quanto pode o formador realizar oficinas de alfabetização que priorizam a vivência de práticas, mas o maior agravante para a área de matemática é que esse componente, quando existe, volta-se exclusivamente para a alfabetização em língua materna e a especificidade da alfabetização em outras áreas do conhecimento fica em segundo plano ou não é objeto de estudo.

Diante desse quadro, é importante debruçar-se sobre a complexidade desse problema: em que espaço o professor que irá atuar nos anos iniciais do Ensino Fundamental aprende a ser um alfabetizador em educação matemática? Qual será o ponto de partida desse professor para construir uma teoria e uma prática de alfabetização? Devido à necessidade social de um cidadão alfabetizado, essa preocupação é legítima. Se a formação inicial não oportunizou aprendizagens específicas sobre o fazer em sala de aula de alfabetização, então as políticas públicas voltadas à formação continuada do professor alfabetizador são necessárias. E, apesar de muito já se ter pensado, ainda é pertinente preocupar-se em como diminuir a distância entre o que é estudado em cursos de formação continuada e a prática em sala de aula. Essa preocupação nos motivou no sentido de acolher o convite de um grupo de professoras alfabetizadoras que se viam diante da problemática de construir uma prática pedagógica em alfabetização, pautada nos pressupostos definidos pelo PNAIC - 
Matemática, estudados durante os encontros de formação realizados no ano de 2014 - ano anterior a minha inserção no contexto da escola.

Ao considerar os indicativos encontrados até o momento, vimos que a formação inicial da professora alfabetizadora é a mesma formação do professor que irá atuar nos anos iniciais do ensino fundamental. Essa professora, ao chegar à escola, por opção ou por imposição, assume a responsabilidade de alfabetizar um grupo de crianças. Inferimos que os saberes específicos para realizar essa tarefa são constituídos na prática.

Muitas são as exigências colocadas aos professores, mas o cenário da formação do professor dos anos iniciais não é animador. Nesse sentido, retomamos a afirmação de Muniz (2008), já exposta neste texto, sobre a necessidade de uma maior precisão conceitual acerca do termo políticas públicas, que pode ser visto como processo social e "tomado a partir da ideia da ação de diferentes sujeitos que desenvolvem suas atribuições, e cujo percurso segue uma lógica constituída em contextos mais abrangentes que aqueles concebidos estritamente no campo da educação" (MUNIZ, 2008, p. 4) e reafirmar o desafio que é posto a nós - educadores matemáticos - que devem, além de construir os textos dos documentos legais e dos cadernos de formação, fazê-los ter vida. Talvez isso se torne possível quando o pesquisador se inserir no contexto da escola e se colocar ao lado dos professores em um espaço de diálogo, estudos, reflexões, em experiências de pesquisa, principalmente de pesquisa-formação, em que o pesquisador se aproxima da escola, envolve-se na dinâmica da ação educativa, auxilia na produção de conhecimentos que podem contribuir na resignificação da prática. Vimos, em nossa pesquisa, uma possibilidade de materializar essa proposta de formação.

Em síntese, observamos que: é possível entender a formação como desenvolvimento humano; essa formação precisa ser crítica e emancipatória; a relação teoria e prática, a pesquisa, o trabalho docente e a função de ensinar precisam ser tomados como base para a formação; $o$ desenvolvimento de novas práticas pedagógicas relaciona-se com a problematização e a reflexão, não apenas individuais, mas coletivas, pois a troca entre os profissionais que atuam em um mesmo segmento favorece o pensar sobre o fazer, que não será realizado por um sujeito e, sim, compartilhado por todos os que, na escola, assumirem verdadeiramente a função de ensinar; no curso de formação inicial é preciso que haja uma atenção especial a formação do professor dos anos iniciais (professor polivalente), que assume a tarefa de ensinar diferentes áreas de conhecimento; os pesquisadores especialistas em educação matemática ainda estão em busca de definir quais os projetos de formação melhor conjugam as necessidades formativas dos professores que ensinam matemática nos anos iniciais. Essas observações nos animaram a realizar a pesquisa e os resultados 
que serão descritos e analisados nos próximos capítulos convidam à discussão sobre possibilidades de formação. 


\section{CAPÍTULO 2}

\section{A CONSTITUIÇÃO DE UM ESPAÇO COLETIVO DE PESQUISA- FORMAÇÃO - PERCURSO METODOLÓGICO}

Ao iniciar essa seção, resgatamos a ideia de que a formação continuada de professores é permanente, é um processo em que conhecimentos são construídos em busca de soluções para os problemas próprios de sua ação docente, principalmente quando se trata do ensino e da aprendizagem na área de matemática.

Como integrante de um programa de pós-graduação e, principalmente, como estudiosa na área de educação e conhecedora das muitas críticas dirigidas a conhecimentos que são construídos na emergência das ações, mas que não são devidamente legitimados por falta da adoção de uma sistemática de pesquisa, buscamos referenciais teóricos para caracterizar este trabalho e validá-lo como uma pesquisa. Isso porque acreditamos que os conhecimentos que poderiam ser produzidos, junto com as professoras, aos serem divulgados, serviriam de referência para outros trabalhos de pesquisa e formação.

Em nossos estudos, a princípio, definimos por adotar a metodologia da pesquisa - ação. E encontramos em Thiolent (2000) e Barbier (2007) bases conceituais que indicavam para a definição de nosso trabalho como uma pesquisa-ação e em Franco (2005) algumas reflexões sobre a pesquisaação como prática educativa. Os estudos de Franco (2005) sobre pesquisa-ação ajudaram-nos a situar esse tipo de pesquisa como uma prática educativa. E, ainda os estudos de Lima e Martins (2006) defendem uma perspectiva da pesquisa-ação como possibilidade para a prática problematizadora. $\mathrm{Na}$ área de educação matemática, atentamos a referências significativas à pesquisa-ação, como em: Fiorentini (2004), Nacarato (2000) e Muniz (2009).

Entretanto, houve na definição do problema de pesquisa, uma diferença entre a questão definida pela pesquisadora e a questão posta pelo grupo de participantes da pesquisa. Isso provocou uma incoerência: na pesquisa-ação o pesquisador se insere na comunidade e o processo de pesquisa desenvolve-se para resolver um problema definido pelo grupo, a fim de responder a uma pergunta do grupo de participantes e não a uma questão proposta pelo pesquisador.

Observamos, que em nosso caso, a identificação do problema pelo grupo de professoras ocorreu quando essas participaram do curso de formação do PNAIC- Matemática- 2014. Nos contatos iniciais, entre pesquisadora e professoras, externaram as dificuldades em implementar em 
sala de aula as propostas de atividades apresentadas durante o curso. Os membros da comunidade escolar, coordenadora, gestora e professoras, já haviam tentado atenuar as suas inquietações, por meio da tentativa de realizar encontros de formação, nos horários de coordenação ${ }^{12}$ individual e coletiva. Ao avaliarem suas ações, as alfabetizadoras e coordenadoras viram a participação de um estudioso nessa área como uma ajuda necessária na busca de alternativas para solucionar esse problema: Como colocar em prática as atividades para a alfabetização matemática propostas no curso de formação do PNAIC- Matemática em 2014?

Esse era o questionamento posto pelo grupo. A pesquisadora havia definido uma questão de pesquisa que, na sua busca de resposta, poderia convergir e até mesmo atender aos anseios do grupo, mas que não havia sido proposta pelo grupo e, sim nascida de suas próprias inquietações, já expostas anteriormente, e relacionada aos seus objetivos de pesquisa.

Isso nos encaminhou em busca de outro referencial metodológico e ao tentar equacionar as questões do grupo com a nossa questão de pesquisa, propusemos uma metodologia em que predominou o trabalho coletivo e, em muito, se aproximou das referências que encontramos sobre pesquisa-formação.

\subsection{A PESQUISA - FORMAÇÃO: POSSIBILIDADES DE FORMAÇÃO EM UM TRABALHO COLETIVO}

Buscamos um referencial mais coerente com a nossa intenção de constituir na escola um espaço de discussão, reflexão e problematização, que se configurasse como formação continuada, contribuísse para a produção de conhecimentos de forma coletiva, que iriam alimentar a prática das professoras de modo que essas pudessem reorganizar seu trabalho pedagógico quando percebessem a relação entre teoria - prática e, de forma autônoma e consciente, constituíssem seus referenciais que seriam o suporte para a construção de sua práxis, uma práxis que, a princípio, poderia ser reiterativa, mas no dinâmico processo de pesquisa e formação poderia vir a transformar-se em uma práxis emancipatória.

Nessa busca encontramos em Longarezi e Silva (2013) uma referência que contribuiu para o nosso entendimento sobre pesquisa-formação que:

não é qualquer tipo de pesquisa que pode ser empregado com a finalidade de agenciar formação, mas somente aqueles que possibilitem uma participação efetiva dos professores nas atividades realizadas, que apresentem uma flexibilidade com relação ao conteúdo investigado e cuja finalidade priorize mais promover formação do que coletar dados. Nessa perspectiva, a formação continuada se conduz mediante a promoção de situações em que os

\footnotetext{
${ }^{12}$ Cada professor reúne-se com a coordenadora pedagógica nos horários em que as crianças têm aula de informática ou recreação - coordenação individual. Na sexta-feira acontece a coordenação coletiva, durante uma hora e meia em cada turno.
} 
próprios educadores possam desenvolver e produzir saberes sobre suas práticas, articulando-os com as teorias educacionais mediante processos de investigação e colaboração em seus espaços de trabalho. (LONGAREZI e SILVA, 2013, p. 216)

Os autores advertem que esse não tem sido o fundamento metodológico, ideológico e político de muitas pesquisas. Às vezes o conhecimento produzido não implica em melhoria da qualidade da educação e da sociedade. Em nossa pesquisa, mesmo, com incertezas quanto à possibilidade das alfabetizadoras participantes tornarem-se colaboradoras, vimos alguma convergência entre a nossa intencionalidade de pesquisa e essas indicações, pois pretendia-se configurar um espaço de formação continuada e contar com a participação efetiva das professoras nas atividades realizadas, isso exigiria flexibilidade com relação ao conteúdo investigado e ter como prioridade promover formação e, realmente, mais do coletar dados, buscamos produzir informações relevantes para análise do próprio processo que seria, ao mesmo tempo, pesquisa e formação.

Ressaltamos, que em nosso trabalho, não se pretendia qualquer formação, mas sim um processo de pesquisa-formação. Esse encaminhamento metodológico foi se constituindo com a nossa inserção na escola, na consolidação dos objetivos e no amadurecimento dos estudos sobre práxis, práxis pedagógica, emancipação, autonomia intelectual e formação continuada em serviço na escola.

Assim, podemos concordar com Longarezi e Silva(2013) quando afirmam que é possível ver a "formação de professores como processo de aprendizagem da docência e, por isso, processo educativo, a articulação pesquisa-formação representa um processo de superação de formas convencionais de pesquisa e de formação" (p. 215). E, que "não se trata de transformar os professores em pesquisadores profissionais, mas de realizar um trabalho conjunto, que gere benefícios a ambos" (p. 216). Assim, seria possível reconhecer "a força e o potencial da articulação pesquisa-educação como desencadeadora de processos formativos conscientizadores e desalienantes" (p. 216). Vimos nessas afirmações possibilidades de delinear um caminho de pesquisa que iria atender tanto aos objetivos da pesquisadora quanto as necessidades postas pelas alfabetizadoras, pois poderíamos desencadear um processo formativo e na tentativa de constituir uma autonomia intelectual das participantes esse processo poderia vir a ser conscientizador e desalienante.

Nos preocupamos com algumas características deste tipo de pesquisa, por exemplo, em como dar conta da necessária dimensão política da pesquisa, pois como afirmam os autores: 


\begin{abstract}
alguns, embora possa contribuir na melhoria de algumas práticas. Tomando por base essa constatação, a pesquisa-formação como processo de desenvolvimento profissional e mudança efetiva nas práticas educativas na perspectiva que defendemos se caracteriza por ser uma metodologia de pesquisa em que todos os sujeitos envolvidos participam ativamente do seu processo, investigando situações-problema na busca por construir respostas e soluções para elas; compreende pesquisa acadêmica e prática pedagógica como unidade; é desenvolvida por todos os seus membros mediante discussões e interações diversas; parte das necessidades dos sujeitos envolvidos, dando sentido ao processo que estão vivenciando; ocorre no contexto escolar; toma a prática pedagógica como conteúdo do processo formativo; respeita as diversas formas de saber existentes; e, fundamentalmente, é processo de formação política. (LONGAREZI e SILVA, p. 223)
\end{abstract}

Neste sentido, pretendíamos que o espaço de formação continuada desenvolvido na escola passasse a integrar o Projeto Político Pedagógico da Escola, não o documento formal, mas o conjunto de ações desenvolvidos pelas profissionais atuantes na escola. Possivelmente, assim, seria dado conta dessa dimensão. Acreditávamos, que ao tomarmos como base a pesquisa acadêmica e a prática pedagógica como objeto de análise, envolvendo as professoras como sujeitos participantes da pesquisa, não prescrevendo formas de fazer, mas sim incentivando a busca coletiva de alternativas para superar uma prática pedagógica em alfabetização matemática que, de acordo com as participantes, era desprovida de sentido e constituir uma práxis pedagógica que atendesse aos objetivos de seus projetos de trabalho com as crianças, estaríamos no caminho de configurar uma pesquisa, com uma centralidade na dimensão formativa e integrada a essa estaria a dimensão política.

No processo de pesquisa, esse aspecto foi evidenciado, pois o critério de definição da escola - uma escola em que o grupo de profissionais fosse em sua maioria professoras concursadas - era uma garantia da maior disponibilidade das participantes em constituir um trabalho mais consistente e com tendência a tornar-se uma política de formação definida e gerenciada pela escola e que, caso houvesse interesse de outros grupos de professores em outros espaços escolares abrir-se-iam a possibilidade de ampliação do grupo de trabalho. Entendemos que a escola como espaço público é espaço político e nesse micro espaço tomado em sua totalidade desenvolvemos uma pesquisa voltada para uma área específica do conhecimento e para um segmento específico da educação básica - o Ciclo de Alfabetização, no caso apenas as classes de $2^{\circ}$ e $3^{\circ}$ ano - mas as aprendizagens derivadas dos estudos, das discussões e problematizações poderiam provocar mudanças de postura que seriam refletidas nas outras áreas de conhecimento que integram o currículo do Ciclo de Alfabetização, mudanças inclusive na forma de ver e relacionar-se com os objetivos de ensino e com as formas de organização de seu trabalho pedagógico. Em nossos resultados será possível perceber os avanços e as limitações que foram explicitados no processo de formação e pesquisa. 
Ainda encontramos em Perrelli, Rebolo, Teixeira e Nogueira (2013) reflexões sobre os desafios enfrentados no desenvolvimento de uma pesquisa-formação que investigou professores da educação básica e seus processos de aprendizagem da docência. Procuraram conduzir seus trabalhos de pesquisa atentando para a dimensão formativa da pesquisa e, segundo eles, essa dimensão formativa seria propiciada, sobretudo, pela aprendizagem conjunta e reflexiva. Apoiaram-se na concepção de "pesquisa-formação" defendida por Josso (2004). E, assim esclarecem que nesta forma de fazer pesquisa o pesquisador-formador, redefine o seu papel enquanto pesquisador e "ao invés de distanciar-se para tentar controlar e explicar os fenômenos, procura construir significados e sentidos, formar e (trans) formar-se durante a ação da pesquisa. " E, desse modo, tem-se a dimensão formativa como elemento potencial e primordial da investigação.

Essas discussões contribuíram em muito para a tessitura de nosso referencial metodológico, que mesmo após a finalização de uma etapa inicial de pesquisa (de 2015 ao primeiro semestre de 2016) e com a construção do relatório, a definição das categorias de análise e defesa de uma tese referente a esse período de pesquisa - ainda está em constituição, pois a pesquisa - formação na escola continua como iremos relatar nas nossas considerações.

Mesmo com essas definições e indefinições, mas com a clareza do objetivo da pesquisa, aceitamos o convite das professoras e nos colocamos na escola em busca de construir um trabalho coletivo. A seguir apresentamos as características do grupo de trabalho, do local da pesquisa e descrevemos o caminho que percorremos para produção das informações e definição das categorias de análise.

\subsection{CENÁRIO DA PESQUISA: O LOCAL E O GRUPO DE TRABALHO}

A pesquisa foi realizada em uma escola pública da rede municipal, no município de Barreiras, localizado na região Oeste do Estado da Bahia. A escola campo de pesquisa passou a existir em 1998, a fim de atender a necessidade de uma escola no bairro. Atualmente, a escola ainda funciona em um prédio alugado, constituído de seis salas de aulas de tamanhos variados, um laboratório de informática, uma sala de leitura e uma sala de atendimento especializado (AEE). Dispõe, também, de quatro banheiros, sendo dois para alunos, um para todos os profissionais do estabelecimento e um para alunos com deficiência, uma diretoria que funciona também como secretaria; uma cantina; uma sala de coordenação; um almoxarifado e um pequeno pátio.

Os estudantes dessa escola se caracterizam, socioeconomicamente, por pertencerem a uma comunidade com alto índice de desemprego, cuja renda familiar compreende, aproximadamente, 
entre 1 e 2 salários mínimos. Em sua maioria, as famílias são assistidas pelo Programa Bolsa Família e seus membros têm, predominantemente, o nível de escolaridade correspondente ao ensino fundamental incompleto ou a não alfabetizados. Os pais trabalham e os filhos permanecem sozinhos em casa no turno oposto ao de frequência à escola. Isso, segundo a vice-diretora, tem reflexos na falta de acompanhamento das atividades extraclasse, o que pode ser um fator que contribui para o baixo rendimento escolar. Hoje ${ }^{13}$, atende a alunos do $2^{\circ}$ e $3^{\circ}$ Ano do Ensino Fundamental I, nos turnos matutino e vespertino, totalizando uma clientela de 228 alunos, com faixa etária entre 7 e 10 anos.

$\mathrm{Na}$ escola, em 2015, ano do início da pesquisa atuavam 08 professoras como alfabetizadoas nas turmas de $2^{\circ}$ e $3^{\circ}$ ano. Entre essas, 07 participaram dos encontros do PNAIC - Linguagem, no ano de 2013, e em 2014 dos encontros do PNAIC - Matemática. Além das professoras alfabetizadoras, participaram ativamente dos encontros de discussão a coordenadora pedagógica, a professora da sala de recursos e a diretora. Destacamos que entre as 08 alfabetizadoras, 04 haviam cursado graduação em Pedagogia e Especialização na área de educação. Entre as outras quatro alfabetizadoras, uma cursou licenciatura em letras, uma estava cursando o Bacharelado Interdisciplinar em Humanidades, uma estava cursando Pedagogia e uma havia cursado Magistério _ Nível Médio. As três outras participantes da pesquisa eram Pedagogas e haviam também cursado especialização na área de educação. Em alguns encontros contamos com a presença das professoras - auxiliares que atuavam nas classes em que houvessem crianças portadoras de necessidades especiais.

O quadro, apresentado a seguir, mostra a formação e tempo de atuação das professoras, diretora e coordenadoras.

Quadro 1 - Formação e tempo de atuação das participantes ${ }^{14}$

\begin{tabular}{|l|l|c|c|c|}
\hline $\begin{array}{l}\text { Alfabetizadoras } \\
\text { Coordenadoras } \\
\text { Gestora }\end{array}$ & \multicolumn{1}{|c|}{ Formação } & $\begin{array}{c}\text { Tempo de } \\
\text { serviço no } \\
\text { magistério }\end{array}$ & $\begin{array}{c}\text { Tempo de } \\
\text { atuação na } \\
\text { alfabetização }\end{array}$ & $\begin{array}{c}\text { Tempo de } \\
\text { atuação nesta } \\
\text { escola }\end{array}$ \\
\hline \multicolumn{5}{|c|}{ ALFABEIZADORAS } \\
\hline Ananda & Pedagogia - Pós-graduação & 10 anos & 01 ano & 01 ano \\
\hline Daniele & $\begin{array}{l}\text { Cursando Graduação em } \\
\text { Bacharelado Interdisciplinar } \\
\text { em Humanidades }\end{array}$ & 04 anos & 04 anos & 04 anos \\
\hline Fátima & Nível Médio - Magistério & 10 anos & 04 anos & 04 anos \\
\hline Francisca & Cursando Pedagogia & 13 anos & 07 anos & 07 anos \\
\hline Irani & Letras - Pós- graduação & 08 anos & 08 anos & 08 anos \\
\hline
\end{tabular}

\footnotetext{
${ }^{13}$ Informações contidas no Plano de Gestão Escolar.

${ }^{14}$ As participantes autorizaram a divulgação dos seus nomes.
} 


\begin{tabular}{|l|l|c|c|c|}
\hline Jancy & Pedagogia - Pós- graduação & 15 anos & 05 anos & 05 anos \\
\hline Luciane $^{15}$ & Pedagogia - Pós- graduação & 15 anos & 10 anos & 10 anos \\
\hline Sandra & Pedagogia - Pós- graduação & 24 anos & 04 anos & 04 anos \\
\hline \multicolumn{5}{|l|}{ OUTRAS PROFISSIONAIS PARTICIPANTES DA PESQUISA } \\
\hline $\begin{array}{l}\text { Edinólia } \\
\text { Diretora }\end{array}$ & Pedagogia-Pós - graduação & 19 anos & 15 anos & 15 anos \\
Cliete & Pedagogia - Pós - graduação & 16 anos & 08 anos & 08 anos \\
\hline $\begin{array}{l}\text { Joseane } \\
\text { Sala de Recursos }\end{array}$ & Pedagogia- Pós - graduação & 10 anos & 05 anos & 05 anos \\
\hline
\end{tabular}

Fonte: Arquivo da pesquisadora, 2015.

Observamos que as que tem maior tempo de atuação profissional cursaram pós-graduação. E, existe um número significativo que trabalha a mais de cinco anos nesta escola o que contribui significativamente com a integração do grupo e com a possibilidade de realizar um trabalho coletivo.

\subsection{DESCRIÇÃO DO ESPAÇO E DAS AÇÕES DE PESQUISA}

Como já descrevemos, a aproximação com a escola campo de pesquisa se iniciou a partir do convite das professoras que participavam dos encontros do curso de formação do PNAIC em 2014. Esse convite levou-nos a escola e a conversar com as coordenadoras e com a direção. A partir de fevereiro de 2015, iniciamos as entrevistas com a coordenadoras e de março a dezembro daquele ano estivemos continuamente no campo de pesquisa, em permanente diálogo com os participantes.

Retornamos à escola em fevereiro de 2016, mas tivemos que aguardar a reorganização do trabalho para retomarmos as ações de pesquisa e formação, pois o início do ano letivo teve muitos problemas, como adiamento do início das aulas por falta de professores e de organização do espaço físico em alguns prédios escolares, além de paralisação dos professores da rede. Assim, esse relatório de pesquisa refere-se, em maior proporção, ao intenso período de trabalho, desenvolvido em 2015, que oportunizou a constituição de muitas informações registradas em diário de campo, em áudio e vídeo, além de um acervo de produções das professoras, das coordenadoras e dos estudantes, como mostra o esquema apresentado no quadro 2.

\footnotetext{
${ }^{15}$ A professora Luciane no ano de 2015 atuava em um dos turnos como coordenadora.
} 
Quadro 2 - Dinâmica de observação discussão, registro das informações

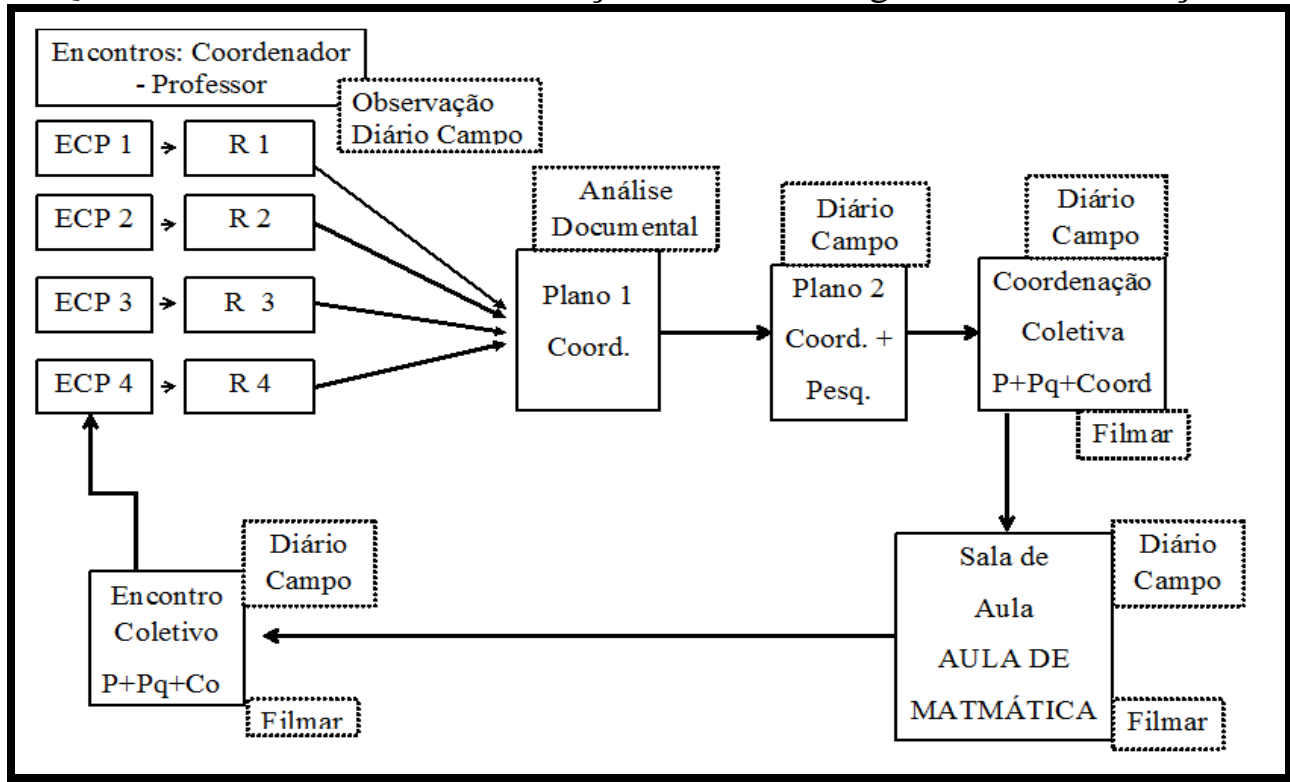

Fonte: elaborado pela autora da pesquisa.

Esse processo dinâmico consistiu: na participação da pesquisadora nos encontros individuais entre coordenadora - professora $(\mathrm{ECP})$, essa participação resultou na produção de relatório, a cada encontro (ECP) um relatório (R); na análise do plano de trabalho produzido nesse encontro (análise documental - Plano 1), na devolução pela pesquisadora do plano à coordenadora com observações (plano 2), que poderiam ou não ser consideradas; na participação da pesquisadora no momento de coordenação coletiva (pesquisadora+ professoras+ coordenadoras - momentos gravados em áudio e vídeo a partir da autorização do grupo); na participação da pesquisadora nas aulas e na discussão das observações na coordenação coletiva, com discussões do que foi observado, gravado em áudio e vídeo.

As informações foram tratadas, aqui, a fim de serem validadas como "informações de pesquisa", pois nossa intenção é que sejam consideradas como resultados de um estudo sistemático em que instrumentos de pesquisa foram utilizados de modo consciente e sério. E, mesmo que não possam ser generalizadas, essas informações podem servir de referência a outros estudos sobre o mesmo objeto, a saber: a constituição de uma práxis em alfabetização matemática. Dividimos o tratamento das informações em três fases que denominamos de:

Fase 1: Organização das informações

Fase 2: Definição das categorias (ou Emersão das categorias)

Fase 3: Análise das categorias.

A primeira fase - organização das informações - foi essencial, pois oportunizou um encadeamento de ideias e o clareamento dos fatos, antes de proceder a uma análise mais categórica. 
Nessa fase, destacamos três espaços de ação e pesquisa que direcionaram o trabalho: (i) elaboração dos planos de trabalho; (ii) realização da aula; (iii) encontros de estudo, discussão e problematização da prática. Esses não foram espaços estanques, mas dialogaram entre si durante todo o processo. E, entre todas as ações realizadas com o grupo de alfabetizadoras, seis se destacaram: (1) a evolução na contagem com a coleção de tampinhas; (2) o estudo das operações aritméticas; (3) interpretação dos problemas do livro didático; (4) a exploração do contexto dos paradidáticos de literatura infantil na construção de situações problemas em matemática; (5) a construção, proposição e análise de um instrumento de avaliação diagnóstica; (6) o encontro literário em alfabetização matemática.

Nessas ações, foi possível explorar alguns dos conceitos matemáticos que constituem os eixos de aprendizagem previstos no currículo para o Ciclo de Alfabetização, mais enfaticamente os conceitos que integram o eixo números e operações, pois não fizemos imposição dos conteúdos a serem estudados e sim respeitamos as solicitações do grupo.

Nessas ações, também foram discutidos e problematizados os conhecimentos pedagógicos relacionados ao ensino e a aprendizagem desse eixo. A organização do trabalho pedagógico das alfabetizadoras foi um conceito central nos nossos encontros de discussão, a fim de ter uma base para olhar para a prática como um objeto de análise e para buscar transformá-la em práxis.

Em nossas discussões e ações coletivas, mantivemos presente o pressuposto defendido, desde a proposição da pesquisa, que a práxis se constitui numa ação transformadora da realidade. A prática pedagógica pode ser entendida como práxis pedagógica quando transcende a dimensão do fazer prático e integra a dimensão de uma ação transformadora, que se constituiria quando as integrantes do grupo de trabalho, no nosso caso, as alfabetizadoras, fossem envolvidas em problematizações e reflexões sobre sua ação de alfabetizar em matemática.

Para explicitar a dinâmica do processo de pesquisa, descrevemos, a seguir, três espaços importantes que se constituíram, durante a nossa permanência na escola: a elaboração dos planos de trabalho; as aulas de matemática e os encontros de estudo, discussão e problematização da prática. Como ressaltou Muniz $(2016)^{16}$, esses espaços não foram criados pela pesquisa, já existiam previamente na escola; a pesquisadora se apropriou desses espaços para o desenvolvimento da investigação numa articulação entre práxis e formação. Concorda-se com a afirmação desse autor quando diz que, de início, ocorreu uma adequação da pesquisadora à realidade da comunidade escolar e não que a escola tenha se adequado à pesquisa e, com o passar do tempo e com o engajamento processual, cada vez mais, viu-se a pesquisa ressignificar estes espaços institucionais.

\footnotetext{
${ }^{16}$ Em reunião de orientação, junho 2016.
} 


\subsubsection{A elaboração dos planos de trabalho}

No início de nossa aproximação com a escola, as coordenadoras expuseram como acontecia a elaboração dos planos de trabalho. O primeiro passo ocorria no início da unidade programática quando, juntas, professoras e coordenadoras decidiam o que seria trabalhado na unidade de acordo com o previsto na Proposta Curricular da Secretaria Municipal de Educação. A cada semana, sucedia-se o seguinte movimento: na segunda-feira a primeira professora da manhã participava de uma hora de coordenação (professora e coordenadora). Naquele momento, as ideias gerais do trabalho para a próxima semana eram registradas em um caderno, com base no trabalho da semana anterior e na perspectiva do trabalho da semana que se iniciava. Portanto, na segunda-feira de uma semana, iniciava-se o planejamento da semana seguinte. Esse caderno ficava sobre a mesa da coordenação. Havia um caderno para cada ano. Após uma hora, a primeira professora retornava a sala de aula e a segunda professora dava continuidade ao que foi iniciado pela colega que a precedeu e registrava as suas sugestões para o trabalho. Continuava-se desse modo na segunda e terça-feira, pela manhã e à tarde, de acordo com o horário de coordenação individual de cada professora que ficava afixado no mural da sala da coordenação.

Esse planejamento inicial ocorria apenas na segunda e terça. Na quarta e quinta-feira, as coordenadoras, a partir do que havia sido registrado no caderno por todas as professoras, em cada ano, faziam as conexões e os ajustes necessários e pesquisavam informações, textos e imagens a serem anexados ao plano de trabalho. Havia ainda o horário de aula de informática, em que as crianças se dirigiam ao Laboratório de Informática e as professoras permaneciam em sala, aguardando o retorno das crianças. Em algumas vezes, naquele momento, elas dirigiam-se a sala de coordenação para conversar sobre os planos em desenvolvimento na semana e para tirar dúvidas com as coordenadoras.

Todos os arquivos dos trabalhos desenvolvidos nos anos anteriores estavam gravados e serviam de referência e, após serem avaliadas e julgadas adequadas, as atividades já validadas eram inseridas nos planos de trabalho atuais. Nada do que foi pensado e já desenvolvido era descartado. Havia muito conhecimento acumulado e muita experiência que ajudava a tornar mais ágil a elaboração dos planos, principalmente na seleção das atividades para as crianças, tanto as que seriam realizadas em sala, quanto as que seriam tarefas para casa. 
Os livros didáticos usados em 2015 foram os escolhidos em 2012 para serem utilizados em 2013, 2014 e 2015. De acordo com o $\mathrm{PNLD}^{17}$, os livros são escolhidos para serem usados durante 3 anos. Por isso, eles já eram conhecidos das professoras, o que também permitia que o trabalho fosse mais rápido. A celeridade com que os planos de trabalho ficavam prontos era impressionante e um observador precisava ficar atento e permanecer ligado às ações das professoras e coordenadoras para entender a dinâmica do processo, desenvolvido de modo muito rápido, quase automático. Havia pastas para cada área do conhecimento arquivadas nos computadores.

Essas pastas ficavam disponíveis para todas as professoras. Competia às coordenadoras providenciar cópia dos textos e das atividades de cada dia. Ao finalizar esse processo, o plano sistematizado, digitalizado e com os devidos anexos era impresso, entregue as professoras e lido por todas na sexta-feira, no tempo de 1hora e 30 minutos. Assim, todas ficavam cientes das atividades de cada dia e de cada tempo de aula da semana seguinte. E, na segunda seguinte, recomeçavam tudo de novo.

Como informado pelas professoras, no ano de 2009, elas participaram de um curso de formação continuada, oferecido pela Secretaria Municipal de Educação, que teve como objetivo orientá-las na construção de sequências didáticas para alfabetização em língua materna, com base nas discussões de Rogiers (2004) e em outros referenciais específicos de alfabetização e letramento e, desde então, as escolas recebiam um quadro de distribuição da carga horária semanal. A carga horária maior era destinada à área de português. Desde o início, as professoras queixaram-se do pouco tempo destinado à matemática. Entretanto, a escola já recebia uma distribuição do tempo semanal, elaborado com o propósito de garantir que a maior carga horária semanal fosse destinada à leitura e escrita na área de Português, a fim de que as crianças pudessem, ao final do ano, evoluir em direção à alfabetização em língua materna. Às outras áreas era destinado um tempo mínimo, como já apresentado anteriormente. Por conhecer a realidade do município, é possível compreender os motivos que levaram a equipe de Coordenação Pedagógica Geral da Secretaria Municipal de Educação a formalizar esse modo de distribuição da carga horária ${ }^{18}$.

\footnotetext{
${ }^{17}$ O Programa Nacional do Livro Didático (PNLD) tem como principal objetivo subsidiar o trabalho pedagógico dos professores por meio da distribuição de coleções de livros didáticos aos alunos da educação básica. Após a avaliação das obras, o Ministério da Educação (MEC) publica o Guia de Livros Didáticos com resenhas das coleções consideradas aprovadas. O guia é encaminhado às escolas, que escolhem, entre os títulos disponíveis, aqueles que melhor atendem ao seu projeto político pedagógico.http://portal.mec.gov.br/pnld/apresentacao

${ }^{18}$ Não foram disponibilizados pela Secretaria Municipal de educação dados de pesquisa que deram sustentação a essa decisão. Mas houve um consenso entre os coordenadores de que para garantir que a criança aprendesse a ler e escrever diferentes tipos de textos, deveria ser dada prioridade à área de Português com todas as especificidades de consciência fonológica, estruturação de textos, gêneros textuais, produção de textos, indicações gramaticais, entre outros conteúdos específicos da área. Explorar a presença da leitura e da escrita em todas a áreas do conhecimento, aparentemente, só seria possível após a criança apropriar-se da leitura e escrita da Língua Portuguesa.
} 
A equipe denominava esses planejamentos de sequências didáticas, de acordo com orientação da Secretaria Municipal de Educação. Porém, observamos que, na escola campo de pesquisa, tais sequências eram feitas de um modo diferenciado e não se enquadravam em características específicas das sequências didáticas propostas por Rogiers (2004), que foi o referencial adotado pela Coordenação Pedagógica da Secretaria Municipal de Educação, quando da elaboração da Proposta Curricular ${ }^{19}$ da rede de ensino municipal. Do mesmo modo, as sequências de atividades para a aula de matemática não estavam em acordo com o que é proposto por Artigue (2001). De acordo com as coordenadoras, seguiam-se os conteúdos e objetivos previstos na Proposta Curricular, definiam-se as estratégias metodológicas e os recursos e elaborava-se uma sequência de atividades diárias que visavam garantir a exploração dos conteúdos e o alcance dos objetivos. O modelo já estava bem adequado às necessidades da equipe da escola. Então, para evitar qualquer imprecisão conceitual, optamos em denominá-las aqui, para fins de análise, de planos de trabalho.

É importante registrar que, durante o ano de 2013, as professoras alfabetizadoras participaram do curso de formação do PNAIC. Nesse curso, um dos temas de discussão foi a organização do trabalho pedagógico e uma das formas de fazer essa organização seria a sequência didática. Ressalta-se que, no ano de 2013, as sequências estavam voltadas para português: consciência fonológica, leitura e produção de textos, gêneros textuais, entre outras especificidades. No ano de 2014, quando o estudo foi sobre alfabetização matemática, logo nos primeiros cadernos, o tema de discussão foi novamente a organização do trabalho pedagógico. O caderno 1 do PNAIC - Matemática traz um estudo detalhado sobre como organizar o trabalho e apresenta vários relatos de experiência de professoras alfabetizadoras que atuavam em escolas públicas.

O que nos importa é que havia esse planejamento de trabalho, que apresentava uma sequenciação das atividades diárias. Mostrava-se como uma forma consensual da equipe organizar o seu tempo de trabalho em sala de aula. Tinha-se, assim, um registro escrito da intencionalidade do trabalho. Encontravam-se ali as atividades que foram pensadas para serem propostas em sala de aula a fim de explorar diversos conceitos em matemática e nas outras áreas do conhecimento.

Neste documento além dos objetivos, conteúdos, estratégias pedagógicas e recursos, estão bem delimitados os tempos de aula, como sugerido pela Coordenação Pedagógica Geral da Secretaria Municipal de Educação.

Foi possível observar, nas salas de aulas, durante a semana, que esse documento impresso ficava sempre sobre a mesa da professora, provavelmente como um guia para sua ação.

\footnotetext{
${ }^{19}$ Proposta elaborada no período de transição para o ensino fundamental de nove anos.
} 
Evidenciava-se uma clara intenção de todas da equipe de que o trabalho fosse realizado de modo a promover a aprendizagem da criança. Ressalta-se que não se questionava se aprendizagem estava acontecendo e nem se todas as crianças aprendiam, ou qual a familiaridade que cada professora tinha com os conteúdos previstos para serem ensinados. No momento de coordenação coletiva da sexta-feira, não havia tempo para avaliar o que havia sido feito na semana que transcorreu.

Esse fato foi destacado pelas professoras em vários momentos, mas mostrou-se sem alternativa de solução, devido à falta de tempo. Entendemos, então, que o pouco tempo que se tinha era destinado a pensar e registrar o que seria proposto às crianças a cada dia, não havendo tempo para avaliar se o que foi proposto foi produtivo, no sentido de ter promovido a aprendizagem. No início, parecia haver uma crença de que a aprendizagem e o ensino eram indissociáveis, assim: o que foi planejado foi realizado, o conteúdo previsto foi ensinado e, consequentemente, foi aprendido. Esse foi um dos pontos destacados durante a problematização da prática ao iniciarmos nossos encontros quinzenais.

Essa dinâmica de elaboração de um plano de trabalho para uma semana sofreu modificações ao longo dos meses, pois devido aos projetos sugeridos pela Coordenação Pedagógica Geral da Secretaria Municipal de Educação, que exigiam dedicação das coordenadoras às atividades específicas dos projetos $^{20}$, como confecção de painéis e de roupa dos personagens, entre outras atividades, os planos de trabalho passaram a ser pensados para duas ou três semanas, na mesma dinâmica e no mesmo tempo. Em síntese, às segundas e terças, em cada horário de coordenação, eram registradas as sugestões das professoras, os ajustes das coordenadoras nas quartas e quintas e a socialização ocorria nas sextas. Essa dinâmica continuou no ano de 2016.

Não foi objetivo desta pesquisa avaliar esse documento, nem sua dinâmica de elaboração. Nosso intuito foi apenas entender como funcionava esse plano de trabalho, em que todas tinham participado na elaboração, para identificar a aula de matemática dentro dos tempos de aula.

Questionava-se: qual o tempo destinado à exploração dos conceitos matemáticos? Quais as atividades propostas para exploração destes conceitos? O que estava previsto como tarefa da criança? Qual a atuação da criança na aula? De que forma a professora pensava a atividade de alfabetização matemática? Quais conceitos matemáticos eram familiares às professoras? Quais conceitos eram definidos como essenciais e não poderiam deixar de ser explorados? $\mathrm{O}$ que as atividades selecionadas poderiam revelar em termos do que as professoras acreditavam sobre a relação entre a criança e a matemática? Seria possível identificar na sequência de atividades o que

\footnotetext{
${ }^{20}$ Projetos de Leitura. A Secretaria Municipal de Educação definiu que 2015 seria o ano da Leitura. Várias atividades foram desenvolvidas em atenção a essa determinação e os planos de trabalho tinham sempre um livro de literatura infantil como contexto para exploração dos conteúdos.
} 
as professoras pensavam sobre a aprendizagem matemática? E sobre o ensino de matemática nos anos iniciais? E, principalmente, coerente com o foco dessa pesquisa: O que as propostas de trabalho revelavam sobre a prática em alfabetização matemática?

Com esses questionamentos, acompanhamos a elaboração dos planos de trabalho e, inicialmente, focamos as aulas de matemática. Com o decorrer dos dias, começamos a olhar os conceitos matemáticos presentes nas outras áreas e que poderiam ser explorados na mesma sequência de atividades sem ser necessariamente no tempo previsto para aula de matemática. Por exemplo, o estudo do bairro, previsto em Ciências Sociais, seria uma oportunidade de explorar muitos conceitos geométricos.

Ao colocarmos essa ideia em discussão, nos encontros de sexta-feira, nós esbarramos em alguns obstáculos, como: é preciso conhecer muito um objeto de estudo para que se possa enxergálo sobre diferentes ângulos e em diferentes contextos. As conexões entre diferentes áreas do conhecimento e a matemática já é algo discutido há algum tempo. Várias situações em que é possível explorar essas conexões podem ser encontradas de modo sistemático nos Parâmetros Curriculares Nacionais, desde 1998, e nos cadernos do PNAIC, especificamente no caderno 8, estudado pelas professoras no ano de 2014. Entendemos que superar a visão compartimentada dentro da própria matemática seria um desafio e o desafio maior ainda seria superar a compartimentalização entre as diferentes áreas.

Enfim, evidenciou-se como mais significativo a existência de um documento orientador da prática, um registro escrito para guiar a ação das professoras em todos os tempos da aula. Neste momento não nos deteremos nas discussões sobre a diversidade de atores que se encontram em sala de aula e a diversidade de conceitos que podem emergir em cada atividade proposta e que podem mudar toda a dinâmica da aula. Um plano organizador do trabalho diário era considerado, pela equipe de professoras e pela coordenação, como algo extremamente necessário, mesmo que estivesse sujeito a alterações devido a toda complexidade do processo.

E o acompanhamento da elaboração dos planos de trabalho possibilitou o acesso a várias informações importantes para a pesquisa, como: os critérios para definição dos objetivos, a seleção dos conteúdos a cada aula e a cada semana, a quantidade de atividades a ser propostas, a previsão da ação da criança e da orientação a ser dada pelas professoras, enfim, foi possível captar o modo como as professoras viam e percebiam a matemática na alfabetização como analisaremos mais adiante neste texto, pois a elaboração da aula de matemática pautava-se pelas concepções das alfabetizadoras sobre o significado do ensinar e do aprender matemática. 


\subsubsection{Aulas de Matemática}

A aula de matemática aparecia no plano de trabalho diário como um intervalo de tempo em que a professora alfabetizadora deveria explorar os conceitos matemáticos pré-definidos na proposta curricular do município. Havia, no ano de 2015, dois tempos destinados ao ensino e à aprendizagem da matemática, ambos após o intervalo, em que ocorriam a merenda e o recreio. Nas turmas de $2^{\circ}$ ano, essas aulas ocorriam nas terças e quartas-feiras e, nas turmas de $3^{\circ}$ ano, nas quartas e quintas-feiras. Isso tornou possível observar aulas tanto nas turmas de $2^{\mathbf{o}}$ ano quanto nas turmas de $3^{\circ}$ ano. No ano de 2016, com a adesão ao Programa Pacto Estadual de Alfabetização ${ }^{21}$, de as aulas de matemática passaram a ocorrer em três tempos.

Quanto à observação da aula de matemática, foi possível verificar que o padrão predominante era exposição inicial do conteúdo e, mesmo com o auxílio de recursos, todas as ações da aula centravam-se no professor. A divisão de tarefas entre professoras e crianças era algo quase inexistente. A professora definia o que e como deveria ser feito. Por exemplo, ao se propor a ensinar a adição, a aula iniciava com um exemplo de situação aditiva, a professora mostrava o exemplo, resolvia a situação para mostrar como se faz, inclusive informava como deveria ser o registro escrito e distribuía o material (mesmo que a situação fosse com quantidades tão pequenas que seria possível usar apenas os dedos das mãos). Só então as crianças começavam a trabalhar, sendo que esse trabalho tinha de seguir os mesmos passos indicados pela professora. Aos poucos, ao participar dos momentos de elaboração dos planos de trabalho, fizemos questionamentos sobre a ação das crianças na aula e sobre a necessidade de desafiá-las, principalmente, no sentido de acreditar que elas iriam, por meio de tentativas e erros, chegar à solução das situações problemas e, nesse processo, elas mobilizariam conceitos matemáticos.

Diante dos nossos questionamentos, começou a ocorrer uma tentativa por parte das professoras de despreocupar-se tanto em mostrar como se faz e em propor situações que incitassem as crianças a elaborar estratégias de solução. Deste modo, as crianças iriam mobilizar os conceitos matemáticos pré-definidos na Proposta Curricular e, inclusive, poderiam ir além destes. Isso ocorreu, por exemplo, no caso das coleções de tampinhas: a proposta curricular previa a contagem de 1 a 20, na primeira unidade. As professoras colocaram no plano de trabalho situações de contagem até 20. Mas, ao aceitarem a proposta do projeto de coleção de tampinhas, elas desafiaram as crianças a contabilizar e registrar por escrito a quantidade de tampinhas individuais, dos pequenos grupos e o total da turma. Ao aceitarem o desafio, as crianças, literalmente, "entraram no

\footnotetext{
${ }^{21}$ Programa Pacto Estadual de Alfabetização.
} 
mundo da contagem”. E, em junho, muitos já contavam além do 100, o que implicou na ampliação da tabela numérica exposta na sala. Isso também indicou a necessidade de uma revisão das indicações curriculares.

As aulas que assistimos, no início, estavam sempre a oscilar entre uma aula em que a ação da professora predominava e uma aula em que a ação da criança predominava, mesmo que fosse para realizar sozinha as tarefas propostas e seguir o exemplo da professora. Encontrar um meio termo, em que a professora se sentisse confortável em propor atividades e, ao acreditar no potencial da criança, a instigasse a agir de modo a criar alternativas de solução para as situações problema foi um trabalho contínuo e permeado de idas e vindas. Essa mudança exigiria o abandono de vários pré-conceitos, de crenças há muito arraigadas e ainda a superação de lacunas conceituais que poderiam gerar insegurança em dialogar com as crianças e vê-las como produtoras de conhecimento.

\subsubsection{Encontros de formação em Alfabetização Matemática}

No início, havia um desejo das participantes (coordenadora e alfabetizadoras) de promover um curso de formação na escola. Após ter sido convidada pelas professoras em 2014 a ir à escola, conversei com uma das coordenadoras que fez a seguinte afirmação: "precisamos de um curso de formação... iniciei um, mas por falta de tempo só fizemos a leitura de três capítulos de um livro. E, mesmo assim, o que foi lido não foi incorporado aos planos de trabalho" (Diário de campo. Fevereiro de 2015).

A fim de atender a essa demanda da coordenação e, ao mesmo tempo, visando constituir um espaço de discussão, problematização e reflexão sobre a prática em alfabetização matemática (o principal objetivo da pesquisa), fizemos uma proposta de curso de formação, com objetivos, conteúdos, metodologia e cronograma. Os encontros seriam quinzenais e tratariam de temas em ensino e aprendizagem de matemática. No primeiro encontro formal com as professoras, foi apresentado o objetivo da pesquisa e o objetivo dos encontros de formação.

Ao ser dada a oportunidade para que as professoras expusessem suas ideias em um espaço coletivo, surgiram muitos questionamentos quanto à ordem de estudo dos conteúdos de matemática. Após as discussões, foi acertado que a cada encontro deveriam ser estudados os conteúdos que seriam necessários para desenvolver as aulas da semana. Ficamos com um horário bem limitado: os poucos minutos de encontro de sexta eram divididos entre os avisos da coordenação e direção, a 
socialização dos planos de trabalho da semana ou da quinzena e, a cada quinze dias, alguns minutos para a formação em alfabetização matemática.

Como permanecíamos na escola durante toda a semana, todas as oportunidades de diálogo com as coordenadoras e com as professoras foram bem aproveitadas. Nós ocupamos tanto o espaço que fomos chamadas a delimitar o nosso tempo, pois a matemática estava a "crescer" muito. Passamos a ir à escola apenas nas terças, quartas e quintas: nas quartas antes do intervalo para acompanhar o fechamento dos planos de trabalho e sugerir atividades matemáticas, nas terças e quintas após o intervalo para assistir as aulas. E, nas sextas, a cada quinze dias, para os encontros de formação.

Essa dinâmica mudou assim que as coordenadoras se sentiram mais à vontade com a presença da pesquisadora, a partir do mês de agosto de 2015. É importante notar que o que era previsto não se distanciava muito dos modelos formais de curso, com temas pré-definidos e que não se aproximavam muito do cronograma real de aulas. Com as negociações, conseguimos realizar encontros periódicos e discutir temáticas bem mais próximas das necessidades das professoras. $\mathrm{O}$ que foi realizado atendeu melhor as demandas surgidas a cada momento e, mesmo assim, não houve tempo para explorar devidamente os conceitos geométricos, as grandezas e medidas e a estatística.

Apesar disso, consideramos que houve avanços em relação a vários assuntos. Dentre eles, destacamos: ao conceito de número, a operacionalização da contagem oral, a escrita e identificação da sequência numérica até 200 ou mais, o entendimento dos conceitos básicos do Sistema de Numeração Decimal, como a dezena, a centena e a unidade; a relação quantidade contada símbolo; a resolução das operações fundamentais de forma compreensiva; a leitura e interpretação de situações problemas, com a identificação da pergunta do problema e definição de estratégias próprias de solução; a leitura de gráficos e de tabelas e a criação e exploração de situações problemas, a partir da leitura dos paradidáticos.

A preocupação inicial de realizar um curso, com a respectiva certificação das horas, dissolveu-se com o envolvimento na construção de propostas de trabalho. Toda a equipe preocupouse em problematizar a prática, em tentar superar as velhas crenças e, ao mesmo tempo, em preencher as lacunas conceituais em matemática.

\subsection{EMERSÃO DAS CATEGORIAS DE ANÁLISE}

Retomamos, aqui, nosso objetivo de pesquisa que se constituiu em analisar um processo de construção de novas práxis pedagógicas, realizado pelas professoras alfabetizadoras, quando elas 
participam, no contexto da escola, de estudos, reflexões, problematizações e discussões sobre alfabetização em matemática e investigar como essas novas práxis se integram à formação continuada do professor alfabetizador. Isso se fez necessário para lembrar-nos de que havia uma práxis que seria analisada de forma coletiva a fim de promover, caso fosse necessário, o desenvolvimento e o avanço dessa práxis, já existente, para uma mais crítica e criativa.

De início, houve uma concordância em tomar a prática em alfabetização matemática como objeto de estudo, discussão, problematização e reflexão e colocamos como objetivo elaborar propostas de trabalho que poderiam apoiar e, caso houvesse necessidade, transformar essa prática. Esse objetivo não estava claro para todas, no princípio, mas havia um desejo de fazer um trabalho melhor com a matemática. O que seria esse trabalho melhor? Na fala da professora D, gravada em vídeo, vemos que ela realizava o que era proposto para aula de matemática, mas sem compreender com clareza o que estava fazendo. Para ela, então, realizar um trabalho melhor seria constituir uma práxis mais crítica?

A continuidade do trabalho nos deu algumas respostas a essas perguntas. Vimos que essas propostas de trabalho seriam constituídas coletivamente, pois na escola existia uma dinâmica de trabalho coletivo e se era para engajarem-se em algo "diferente" na matemática, umas instigavam as outras a assumirem, juntas, esse desafio.

O termo práxis já pertencia ao vocabulário de algumas professoras, pois em algum momento do curso de formação inicial e dos cursos de formação continuada ocorreram estudos sobre práxis. Mas, a busca de melhor compreender a prática e a possível diferenciação entre prática e práxis e, principalmente, a práxis em alfabetização matemática, criou uma expectativa.

Observa-se que a práxis é algo amplo que vai além do processo de alfabetização matemática e inclui toda a dinâmica de estudos, problematização, reflexão, as práticas de planejar, desenvolver e avaliar as aulas. Os estudos começaram com reflexões, discussões, investigações pedagógicas, que ocorriam em paralelo com a leitura de textos e livros. Os livros da sala de leitura, recebidos pelo PNBE Biblioteca do Professor- MEC foram identificados e colocados à disposição de todos, além dos livros da pesquisadora. A insistência na leitura levou-nos a promover um encontro literário em Alfabetização Matemática, que está entre as ações que mais se destacaram no processo.

Como fonte de consulta sobre metodologias e recursos, além dos livros disponibilizados pela Biblioteca do Professor- MEC, destacamos o Manual do livro didático como uma importante fonte de consulta para as professoras e muito mais confiável do que atividades retiradas de coleções não 
avaliadas por uma equipe de especialistas ${ }^{22}$. Colocamos como materiais de consulta também os cadernos do Programa Gestar I, Pró-Letramento e PNAIC.

O espaço coletivo de reflexão e problematização constituiu-se à medida que permanecemos na escola durante a semana. O tempo todo, no cafezinho, no lanche, na sala de coordenação, na sala de aula. Não era possível esperar para falar apenas nos tempos e espaços estáticos. Tivemos de flexibilizar. Mas a dificuldade da pesquisadora em desapegar-se da forma sistemática e bem "quadrada" de tempo e horário, definidos e demarcados, contribuiu para o uso máximo do tempo mínimo de sexta-feira. Os minutos foram contados para não se perder nenhum e as atividades eram cronometradas. As coordenadoras e professoras ensinaram a pesquisadora que nada ocorre rapidamente. A tensão permanente entre o desejado e o possível tornou o trabalho mais produtivo e mais real, no sentido de mais adequado às condições humanas e materiais da escola.

É importante esclarecer que fizemos um relatório descritivo das seis ações que mais se destacaram no período de fevereiro a dezembro do ano de 2015. O olhar analítico para essas ações, com foco nos objetivos de pesquisa, tornou possível a definição das categorias de análise. Na sessão subsequente, são apresentadas as categorias. Não há intenção de demarcar um "antes" e um "depois", como "antes da inserção da pesquisadora" e um "depois da inserção da pesquisadora". A equipe de profissionais já era uma equipe de trabalho antes da pesquisadora aproximar-se da escola e continuará o seu trabalho em equipe mesmo se, e quando, a pesquisadora se afastar da escola.

Em nenhum momento assumiremos a postura de "era assim" e "ficou assim", pois a tensão entre a pesquisadora e a equipe de profissionais era permanente, não encontramos um grupo disforme que foi "moldado" para ser transformado; pelo contrário, a equipe era extremamente coesa e segura em relação a seu modo de fazer, à sua relação com a comunidade e ao respeito e integração aos projetos definidos pela Secretaria Municipal de Educação. Em alguns momentos as professoras diziam: "vou experimentar essa sugestão, mas não porque você (pesquisadora) disse e nem porque irá assistir à aula, mas porque acho que é coerente". Essas falas evidenciavam que em relação às propostas em outras áreas elas já tinham certa autonomia e essa postura autônoma seria mantida em matemática, mas se queixavam da falta de segurança para adotar outras metodologias que exigiriam um maior domínio conceitual em matemática.

Assim, buscamos estabelecer parcerias com toda a equipe (05 professoras do $2^{\circ}$ ano e 03 do $3^{o}$ ano) com o objetivo de elaborar e implementar uma proposta de trabalho para o ensino de matemática na alfabetização, que fosse promotora de aprendizagem. Convidamos o grupo a adotar

\footnotetext{
22 Às vezes aparecem na escola algumas coleções com atividades desconexas e, em alguns casos, com incorreções. Insistimos muito pela valorização do livro didático que, na área de matemática, avançou muito nas últimas décadas.
} 
como princípio fundamental que as crianças estão em constante processo de aprendizagem e, entre todos os espaços de convívio social em que se encontram, é a escola o principal espaço de aproximação/apropriação com o saber sistematizado. Ora, a escola com toda a sua equipe de profissionais abriu-se pra realizar um trabalho junto com a pesquisadora, aconteceram transformações, algumas superficiais outras mais consistentes, mas não se perdeu de vista que, para que essas transformações fossem incorporadas a rotina do dia a dia da escola, seriam necessárias mudanças estruturais que só seriam garantidas pela vontade política de toda a equipe da escola e, principalmente, pelas políticas públicas que poderiam (ou não) ser implementadas pela gestão municipal.

A partir desses esclarecimentos, agrupamos em categorias as informações produzidas ao olhar analiticamente para as ações. Essas se constituíram entre avanços e limitações, não de forma linear, algumas vezes com ousadia outras vezes com insegurança em um processo de tensão permanente. A própria pesquisa impôs a necessidade de descrever e avaliar cada momento do processo e, nesse movimento, foi possível tornar explícitos alguns conceitos que sustentaram as ações dos envolvidos na pesquisa. Entendemos que a categorização não se fez de uma única vez, ela se processou de forma cíclica e não de modo linear. Assim, à medida que analisamos o texto descritivo construído na fase de organização das informações, novas compreensões surgiram e aprimoraram o sistema de categorias, no sentido de ficar ainda mais coerente com os objetivos da pesquisa. Os elementos comuns não foram selecionados a priori, mas resultaram de um olhar apurado que estabeleceu relações com o objeto de pesquisa, em busca de respostas para as perguntas da presente investigação.

Ressaltamos a importância da organização das informações, pois nos ajudou a constituir unidades de informações, que deram consistência para categorizar e analisar de modo mais sistemático e orgânico. Durante essa organização, revisitamos todo o material produzido enquanto permanecemos na escola e, assim, foi possível caracterizar os três espaços de ação e pesquisa e destacar as seis ações sintetizadas na primeira fase de tratamento das informações. Na leitura e organização das informações emergiram três conceitos fundamentais: alfabetização matemática, formação continuada em serviço e práxis pedagógica em alfabetização matemática. A princípio, esses três conceitos foram vistos como as categorias de análise e definimos o primeiro sistema de categorias, conforme exposto no quadro 03. 
Quadro 3 - Primeira tentativa de definição das categorias

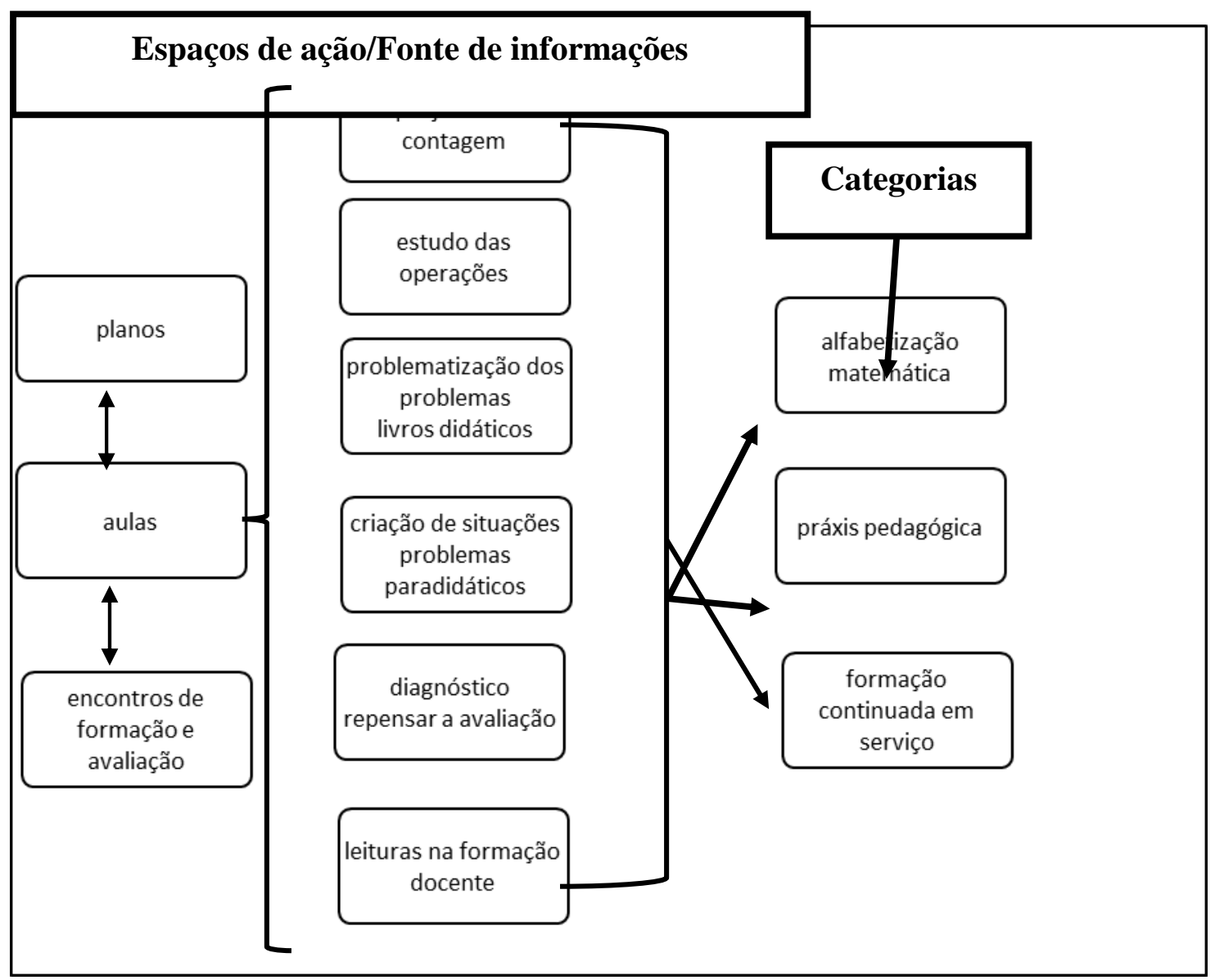

Fonte: Elaborado pela autora.

Entretanto, ao tentar agrupar as evidências para a provável categoria práxis, percebemos que práxis é muito amplo e pode denominar todo o processo de ação-pesquisa-formação. Vimos que ela foi constituída no processo e resultou da imbricação entre a formação e a prática em sala de aula. Assim, pensamos que as categorias poderiam ser: (1) o entendimento das professoras sobre o significado de alfabetização; (2) a prática em sala de aula; (3) a formação continuada em serviço. Uma síntese dessas três categorias seria a práxis em alfabetização matemática. Não mais uma práxis irrefletida, reiterativa (VASQUEZ, 1990), mas uma práxis emancipatória que seria resultante da autonomia intelectual, construída pelas professoras ao: (1) entender quem é a criança que está em processo de alfabetização e em que se constitui esse processo - o que implica em conhecer a gênese dos conceitos matemáticos; (2) transpor os conhecimentos matemáticos e pedagógicos construídos nos encontros e espaços de formação para o seu plano de trabalho, e (3) 
pensar, realizar e avaliar o trabalho, como afirma Serrazina (2012), com plena consciência de todo o processo.

Reafirmamos que na dinâmica da pesquisa e na organização das informações o conceito de práxis em alfabetização matemática emergiu como um conceito central que trouxe em sua constituição os conceitos de alfabetização matemática e de formação continuada em serviço na escola. À medida que a dinâmica de formação foi se concretizando, no espaço de discussão, problematização, reflexão e estudo, o conceito de alfabetização matemática se ampliou e, nesse movimento, o domínio conceitual dos objetos de aprendizagem matemática alargava-se e isso se refletia na elaboração do plano de trabalho e na proposição de atividades que se mostravam, cada vez mais, promotoras de aprendizagens para as crianças.

Ao classificar e agrupar as informações, referentes ao conceito de alfabetização matemática, percebemos que esse conceito se revelava na prática e, na busca de evidências do entendimento das alfabetizadoras sobre o significado de alfabetização, sempre encontramos episódios de aula (gravados em vídeo) ou depoimentos sobre a prática em sala de aula (gravados em áudio), o que tornou complexa a separação entre o conceito de alfabetização e a prática, pois esse conceito foi o norteador da prática. A evidência dessa relação foi traduzida, aqui, como a primeira categoria: (1) o conceito de alfabetização matemática como norteador da prática pedagógica.

A produção de conhecimentos possibilitada pelo processo de pesquisa-formação, se expressou na relação teoria-prática e foi evidenciada na ampliação do conceito de alfabetização que implicou em mudanças nos planos de trabalho e materializou-se na prática pedagógica das alfabetizadoras. Houve um movimento cíclico entre todos esses elementos presentes na pesquisa formação. Esse entendimento implicou na definição da segunda categoria: (2) a relação entre a formação continuada em serviço na escola e as mudanças na prática em alfabetização matemática.

A imbricação das ações que ocorreram no processo, a própria complexidade e a dinâmica das relações estabelecidas durante a pesquisa-formação dificultaram separar e classificar as informações. No entanto, a fim de proporcionar a outros pesquisadores uma visão mais sistemática do processo e dos resultados da pesquisa, procedemos a difícil tarefa de agrupar informações nessas duas categorias de análise: (1) o conceito de alfabetização matemática como norteador da prática pedagógica em alfabetização matemática; (2) a relação entre a formação continuada em serviço na escola e as mudanças na prática em alfabetização matemática. 
Em cada uma foram identificadas subcategorias, o que resultou em:

Quadro 04 - Categorias e subcategorias de análise

\begin{tabular}{|c|c|}
\hline Categorias & Subcategorias \\
\hline \multirow{3}{*}{$\begin{array}{l}\text { 1. O conceito de alfabetização } \\
\text { matemática como norteador da } \\
\text { prática pedagógica em } \\
\text { alfabetização matemática }\end{array}$} & $\begin{array}{l}\text { 1.1. As situações de contagem - aprender e ensinar o conceito } \\
\text { de número na alfabetização }\end{array}$ \\
\hline & $\begin{array}{l}\text { 1.2. Da compreensão do sistema de numeração decimal às } \\
\text { operações }\end{array}$ \\
\hline & $\begin{array}{l}\text { 1.3. Ler e problematizar os problemas dos livros didáticos e as } \\
\text { histórias dos paradidáticos }\end{array}$ \\
\hline \multirow{3}{*}{$\begin{array}{l}\text { 2. A relação entre a formação } \\
\text { continuada em serviço na } \\
\text { escola e as mudanças na prática } \\
\text { em alfabetização matemática }\end{array}$} & $\begin{array}{l}\text { 2.1 As aprendizagens, o abandono de velhas crenças e a adoção } \\
\text { de novas concepções }\end{array}$ \\
\hline & $\begin{array}{l}\text { 2.2. O diálogo teoria - prática, a produção de conhecimentos e a } \\
\text { reorganização do trabalho pedagógico. }\end{array}$ \\
\hline & 2.3. A construção da autonomia intelectual: da prática a práxis. \\
\hline
\end{tabular}

Fonte: elaborado pela autora.

No próximo capítulo, apresentamos as análises referentes à primeira categoria, em busca de evidenciar a relação entre a formação continuada em serviço na escola e as mudanças na prática em alfabetização matemática. 


\section{CAPÍTULO 3}

\section{O CONCEITO DE ALFABETIZAÇÃO MATEMÁTICA COMO NORTEADOR DA PRÁTICA PEDAGÓGICA EM ALFABETIZAÇÃO MATEMÁTICA}

Como foi discutido no primeiro capítulo, entendemos alfabetização matemática como um complexo processo de aprendizagem dos conceitos iniciais de matemática, relacionados a números, operações, grandezas, medidas, formas, localização, orientação, deslocamento, estatística, probabilidade e estimativa. Trata-se de um processo em que, no envolvimento com situaçõesproblema, a criança constrói e mobiliza tais conceitos e suas representações. Esse processo inicia-se fora do contexto escolar, continua, é aperfeiçoado e ampliado quando a criança ingressa na escola, seja nas experiências realizadas na Educação Infantil, seja nos primeiros anos escolares do Ensino Fundamental. Isso implica em aprender a linguagem matemática, conhecer os objetos matemáticos, propor, identificar e resolver situações-problema, desenvolver registros e argumentação oral lógica para comunicar as estratégias de solução e, principalmente, mobilizar os conceitos matemáticos em diferentes situações, tanto dentro quanto fora da escola.

A partir desse entendimento e coerentes com os objetivos da pesquisa, buscamos, como exposto anteriormente, estabelecer parcerias com o grupo de professoras. Nosso intuito foi acompanhar e melhor compreender a proposta de trabalho para o ensino de matemática na alfabetização, que já era implementada na escola, e contribuir nos aspectos necessários ao aperfeiçoamento dessa proposta, de acordo com o que foi solicitado pelas alfabetizadoras no convite feito à pesquisadora.

Agrupamos nessa categoria a análise das propostas de trabalho norteadas pelo entendimento das professoras sobre a alfabetização matemática. Essas evidências foram mais explícitas: - nas atividades de contagem; - no trabalho com os conceitos do sistema de numeração decimal e operações aritméticas; - na proposição de perguntas para ler e problematizar as atividades do livro didático e na exploração dos livros paradidáticos de Literatura Infantil, cujo trabalho consistiu na elaboração coletiva, entre professoras e crianças, de situações-problemas com o contexto das histórias infantis.

Definimos, assim, três subcategorias em que o estudo dos objetos de aprendizagem em matemática evidenciaram o conceito de alfabetização e foram a base para a constituição de novas práticas: (1) as situações de contagem - aprender e ensinar o conceito de número na alfabetização; 
(2) da compreensão do sistema de numeração decimal às operações; (3) ler e problematizar os problemas e histórias dos livros didáticos e paradidáticos;

\subsection{AS SITUAÇÕES DE CONTAGEM - APRENDER E ENSINAR O CONCEITO DE NÚMERO NA ALFABETIZAÇÃO}

Logo no início das observações, percebemos que nas turmas de $2^{\circ}$ ano as atividades previstas para o trabalho de numerização ${ }^{23}$ indicavam que seriam estudados na primeira unidade os números de 1 a 20. Essa delimitação tomava por base um diagnóstico assistemático feito pelas professoras e coordenadoras que conheciam a escola próxima em que as crianças haviam cursado o $1^{\circ}$ ano e sabiam das dificuldades que poderiam impedir as crianças de ir além do número 20 na primeira unidade: nem todas as crianças cursaram a Educação Infantil e, especificamente, no ano de 2014, ocorreram experimentações de alguns programas estaduais e federais que provocaram interrupções no curso de trabalho das alfabetizadoras, o que teve impacto na aprendizagem das crianças do $1^{\circ}$ ano.

Assim, durante as primeiras semanas as atividades priorizaram a contagem de 1 a 10 , conforme se pode observar na Figura, a seguir:

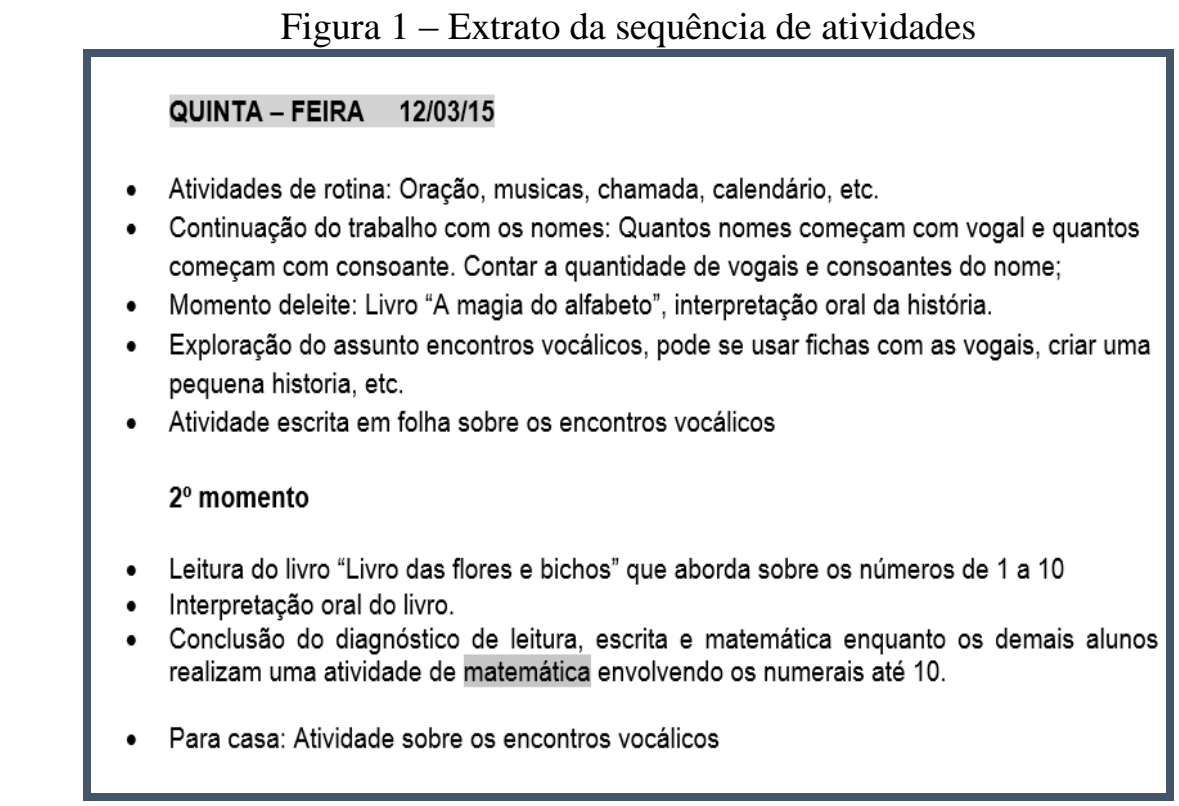

Figura 1 - Extrato da sequência de atividades

Fonte: Arquivo da pesquisadora, 2015.

Entretanto, ocorria que as crianças que estavam no $2^{\circ}$ ano do Ciclo de Alfabetização já conviviam, desde cedo e em diversas situações, com números, assim como com quantidades bem superiores a 20. E, mesmo, sem compreender a estrutura do Sistema de Numeração Decimal, elas

\footnotetext{
${ }^{23}$ Termo empregado por Bertoni (2007) para referir-se ao processo de construção do conceito de número pela criança.
} 
conseguiriam avançar na contagem, na leitura e na escrita dos números. Isso ocorre porque, como comprovam pesquisas como a de Lerner Zunino (1995), elas têm hipóteses sobre a escrita e a leitura dos números. No caderno 2 do PNAIC, Spinillo (2014), também, discutiu o sentido numérico que está presente entre as crianças desde muito pequenas. Nosso questionamento, naquele momento foi: como discutir com as professoras e convencê-las do potencial das crianças para contar além do 20 ? $\mathrm{Na}$ terceira semana de aula, os conteúdos e objetivos ainda focavam a sequência até 20. (Figura 2).

Figura 2 - Previsão de conteúdos e objetivos para a terceira semana

SEQUÊNCIA DIDÁTICA O3 - SOM [P]
ESCOLA MUNICIPAL.............
PÚBLICO ALVO: $2^{\circ}$ ANO PERÍODO: 16 A 20 DE MARÇO DE 2015
DURAÇÃO: 5 DIAS
Conteúdos:
- Língua portuguesa Texto base: Passarinho no sapé(Cecília Meireles)
- Ciências sociais
- Ciências naturais
- Matemática
1. Uso social dos números;
2. Contagem de objetos até 20, estabelecendo a relação entre o numeral (símbolo) e a
- quantidade.
Objetivos:
- Realizar a contagem de objetos pelo uso da sequencia numérica, estabelecendo relação
entre numeral e quantidade.

Fonte: Arquivo da pesquisadora, 2015.

A intenção de explorar a relação entre a quantidade e sua representação escrita, com a realização da contagem com apoio em material manipulável, já havia sido expressa nos objetivos dos planos de trabalho. No entanto, o material ficava na mão do professor. Observamos aulas em que algumas crianças manuseavam o material enquanto o restante observava. Naquele momento, segundo algumas professoras, colocar o material na mão de todos provocava tumulto e era difícil de ser controlado. Esse fato foi destacado por Nacarato (2013):

Há, ainda, que destacar a força da tradição pedagógica no ensino de matemática. Muitas egressas do curso de Pedagogia almejam práticas docentes diferenciadas e até se arriscam no início de carreira. Mas, muitas vezes se sentem sozinhas, inseguras diante do novo: uma turma sob sua responsabilidade - 30 ou mais crianças que precisam ser alfabetizadas, aprender Matemática, Ciências, Geografia, História,... -; um currículo a ser cumprido; as avaliações externas; o controle da sala de aula... Trabalhar de forma diferenciada, em grupos, por exemplo, gera barulho, e é visto por muitos gestores como falta de domínio de sala de aula pela professora iniciante. Assim, pouco a pouco, os ideais de novas metodologias vão sucumbindo diante da resistência dos alunos, das críticas dos pares e dos gestores e, até mesmo, dos pais. As professoras iniciantes acabam entrando na rotina de cumprir o mesmo modelo de aula no qual foram formadas e que é praticado pelas colegas mais experientes da escola, consideradas, muitas vezes, como as "boas professoras". (NACARATO, 2013, p. 31)

No recorte do plano de trabalho apresentado a seguir na Figura 3, vimos que as atividades rotineiras como exploração do calendário (números de 1 a 30 ou 31), exploração da chamada 
(quantidade de meninos e de meninas presentes ou ausentes na aula) ofereciam oportunidades de fazer matemática. Isso, apesar de estar na fala das coordenadoras e das professoras, ainda era apenas algo rotineiro, parecia estar no plano de forma bem automática. Esses aspectos, vistos de outro modo, seriam potenciais espaços de aprendizagem de conceitos matemáticos como conceito de tempo, de números, de operações e de lateralidade (a escrita da esquerda para a direita). Vimos que ainda era proposta, no plano, a contagem de palavras e versos do poema, mas na aula isso ocorria de modo muito rápido, em descompasso com o tempo de aprendizagem da criança.

Figura 3 - Plano de trabalho $2^{\circ}$ ano

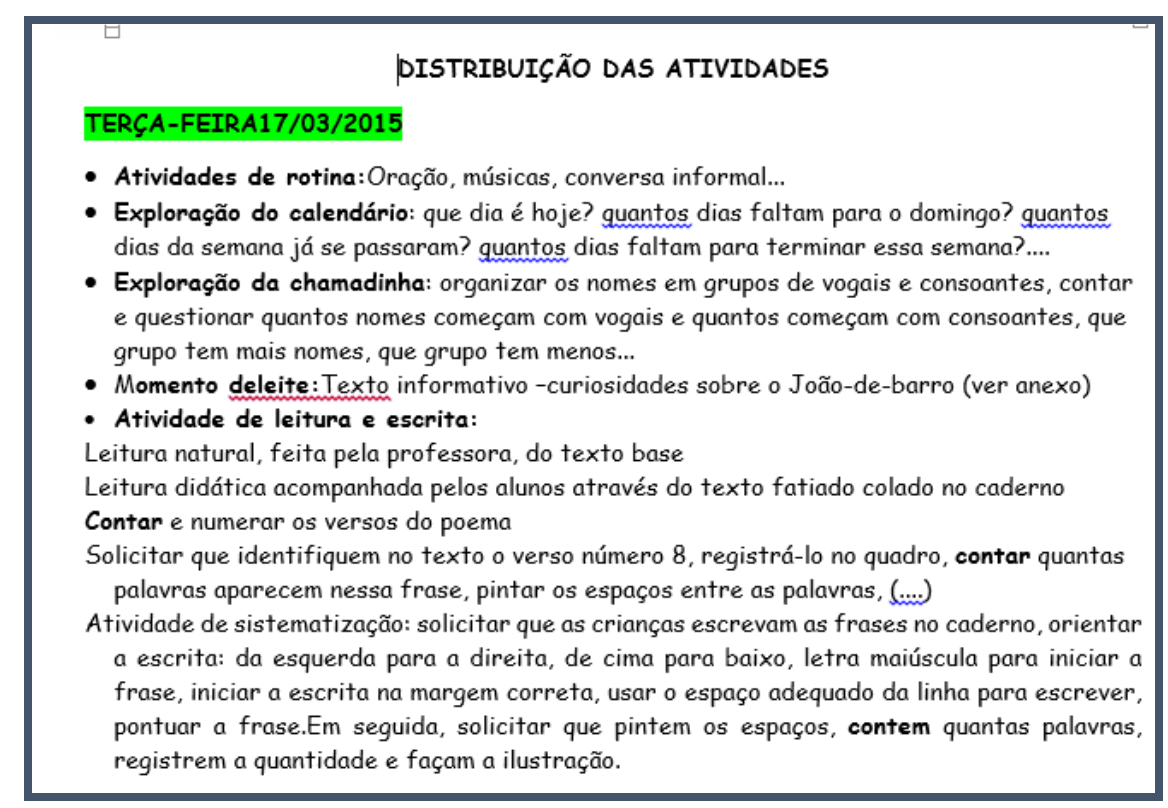

Fonte: Arquivo da pesquisadora, 2015

Nessas simples situações, como na exploração do calendário e na chamada, estão presentes dois conceitos matemáticos importantes: o conceito de tempo e o conceito de número.

Observamos que nas quatro perguntas feitas às crianças, nota-se a presença do termo “quantos”, o que pode indicar o uso do calendário, não para auxiliar a criança na percepção do tempo, mas para apoiar a contagem e propor operações. As noções implicadas no conceito de tempo, como sucessão e duração baseadas na percepção, nem sempre são trabalhadas. E isso pode explicar resultados como os que foram analisados quando da aplicação da avaliação diagnóstica, como se pode verificar a seguir: 
Item - Faça um X no quadradinho que mostra em que dia da semana será o dia 9:

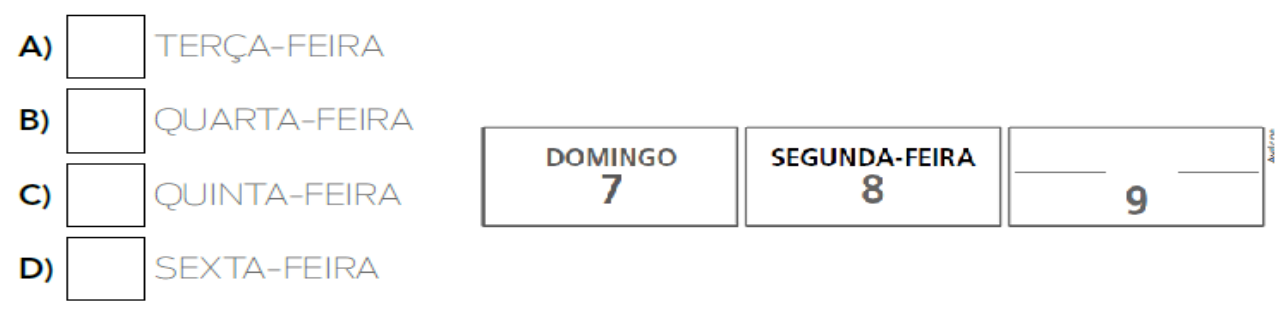

\begin{tabular}{|c|c|c|c|c|c|c|}
\hline \multicolumn{7}{|c|}{ RESULTADOS DAS TURMAS DE $2^{\circ}$ ANO } \\
\hline \multirow{2}{*}{ Item } & \multirow{2}{*}{ Descritor } & \multicolumn{5}{|c|}{$\begin{array}{l}\text { Percentuais de erros } \\
\end{array}$} \\
\hline & & $2^{\circ}$ ano1 & $2^{\circ}$ ano2 & 2 ano 3 & $2^{\circ}$ ano4 & $2^{\circ}$ ano5 \\
\hline $\begin{array}{l}\text { Item } \\
\text { Tempo }\end{array}$ & $\begin{array}{l}\text { H15. Identificar, comparar, } \\
\text { relacionar e ordenar tempo em } \\
\text { diferentes sistemas de medida. }\end{array}$ & $21 \%$ & $27,2 \%$ & $22,35 \%$ & $27,7 \%$ & $14 \%$ \\
\hline
\end{tabular}

\begin{tabular}{|c|c|c|c|c|c|}
\hline \multicolumn{6}{|c|}{ RESULTADOS DAS TURMAS DE $3^{\circ}$ ANO } \\
\hline \multirow[t]{2}{*}{ Item } & \multirow[t]{2}{*}{ Descritor } & \multicolumn{4}{|c|}{ Percentuais de erros } \\
\hline & & $3^{\circ}$ ano 1 & $3^{\circ}$ ano 2 & $3^{\circ}$ ano 3 & $3^{\circ}$ ano 4 \\
\hline $\begin{array}{l}\text { Item } \\
\text { Tempo }\end{array}$ & $\begin{array}{l}\text { H15. Identificar, comparar, relacionar e ordenar } \\
\text { tempo em diferentes sistemas de medida. }\end{array}$ & $30,4 \%$ & $4,3 \%$ & $20 \%$ & $25 \%$ \\
\hline
\end{tabular}

Esses resultados, como outros que serão discutidos na segunda categoria, no próximo capítulo, provocaram muitas reflexões: "se todos os dias exploramos o calendário, o que justificaria esses percentuais?” e, ainda, “o que poderia justificar a diferença de resultados de uma turma para outra?". Naquele momento chamamos a atenção, novamente, para o processo de alfabetização e indagamos: o calendário é algo comum na vida da criança? Como o calendário aparece em nossas casas? Ele é consultado somente pelo adulto ou é consultado também pela criança? Os pais de nossas crianças preocupam-se em instigá-las a entender a lógica de construção do calendário? E nós alfabetizadoras, temos estudos sobre a gênese do conceito de tempo? Nossas propostas de trabalho auxiliam as crianças na percepção da grandeza tempo?

Essas observações nos encaminharam a refletir sobre a nossa formação inicial como alfabetizadora que, como discutimos no primeiro capítulo, ainda carece de um espaço definido e institucionalizado. As nossas discussões e problematizações nos levaram a pensar que precisamos saber mais sobre os conceitos que integram o eixo de grandezas e medidas.

Em Muniz, Batista e Silva (2008), encontramos indicações sobre a complexidade de compreender a medição do tempo. Esses pesquisadores defendem que os estudos, referentes a esse eixo, começam pela percepção das grandezas, nesse caso o tempo. Eles lembram que: 
Na história da humanidade, a marcação do tempo se deu de várias formas. Os homens antigos usaram velas marcadas com traço, pêndulos, ampulhetas, baldes de água, o próprio pé (ainda muito utilizado pelos músicos para marcar o compasso) e o relógio do sol. Alguns desses instrumentos poderão ser utilizados em sala de aula para marcar o tempo das tarefas, levando à construção do conceito de registro da duração de um evento que, em síntese, é a construção da própria percepção do tempo. [...] É importante que o estudante construa o conceito de tempo e conheça meios de medi-lo para desenvolver a habilidade de sequenciar eventos e perceber a sua duração. Neste sentido, propomos agora uma série de atividades onde os elementos da natureza sejam os instrumentos de marcação do tempo. (MUNIZ; BATISTA; SILVA, 2008, p.100-101)

A criança pode levar algum tempo para entender o ontem, o hoje e o amanhã, para identificar intervalos de dias, meses ou anos e, mesmo nas atividades diárias, elas necessitam de orientação para os horários durante o dia: quais as atividades ocorrem pela manhã? Quais atividades ocorrem à tarde?

Quanto ao conceito de número, apesar de aparentemente ser o mais explorado nas turmas do Ciclo de alfabetização, o seu processo de constituição ainda carece de ser mais bem compreendido pelas alfabetizadoras.

A vivência de situações de contagem, como atividade primordial para oportunizar a quantificação, a comparação de quantidades, a correspondência biunívoca, a construção das relações de ordem e inclusão hierárquica Kamii (1990) e Panizza (2006), de certa forma, é deixada de lado, pois demanda tempo e espaço para dispor as crianças e os materiais de contagem e provoca uma certa "desordem" na sala que "tumultua" a aula. Ocorre que a não vivência dessas situações pode implicar em não desenvolvimento de habilidades que são a base para a constituição do conceito de número. Observa-se que a alfabetizadora não precisa se preocupar em informar a criança que irá, de forma estanque, explorar a ordem, a inclusão, a correspondência, a quantificação, a comparação; o mais importante é pensar e propor situações que serão vivenciadas pelas crianças e em que essas estruturas mentais possam se constituir e o conceito de número esteja em processo de formação.

Poderíamos ainda pensar no descompasso entre o tempo de ensinar e o tempo de aprender, conforme aponta Pais (2001). Estavam previstas no plano situações de exploração do calendário e da chamada, mas o tempo para a criança compreender e participar dessas atividades, de modo a realmente a dar respostas aos questionamentos e registrar, mesmo oralmente, as suas hipóteses e estratégias de respostas às situações problemas, era algo ainda distante. A elaboração de um plano de trabalho que considerasse essas especificidades do processo de formação de conceitos matemáticos exigiria da alfabetizadora entender o que significa alfabetizar. Além de dominar os conceitos, seria necessário saber como aproximar a criança, que está no Ciclo de Alfabetização, 
desses conceitos. Isso demanda um conhecimento pedagógico que vai além e, ao mesmo tempo, engloba o domínio conceitual (SCHULMAN, 1986).

Na Figura 3 acima, observamos em um recorte do plano de trabalho que, apesar do intervalo de tempo da aula de matemática ser de uma hora e meia, estavam previstas no plano, além da construção da linha do tempo, a exploração oral de situações problemas, a abordagem da presença dos números no dia a dia e a proposição de situações que seriam resolvidas com uso do material concreto. Cada uma destas atividades demandaria tempo para ser realizada pela criança que, repetimos, está no processo de se aproximar dos conceitos e mobilizá-los em situações escolares que têm uma natureza diferenciada das situações cotidianas. Na figura 44, vemos que no primeiro e no segundo momento da aula de quarta-feira, aparecem no plano de trabalho interessantes situações de contagem: contar quantas vezes a palavra passarinho aparece no texto, quantas letras tem essa palavra, quantas vogais e quantas consoantes, contar quantas vezes a letra $\mathrm{P}$ aparece no texto, entre outras.

Figura 4 - Atividades previstas para a aula

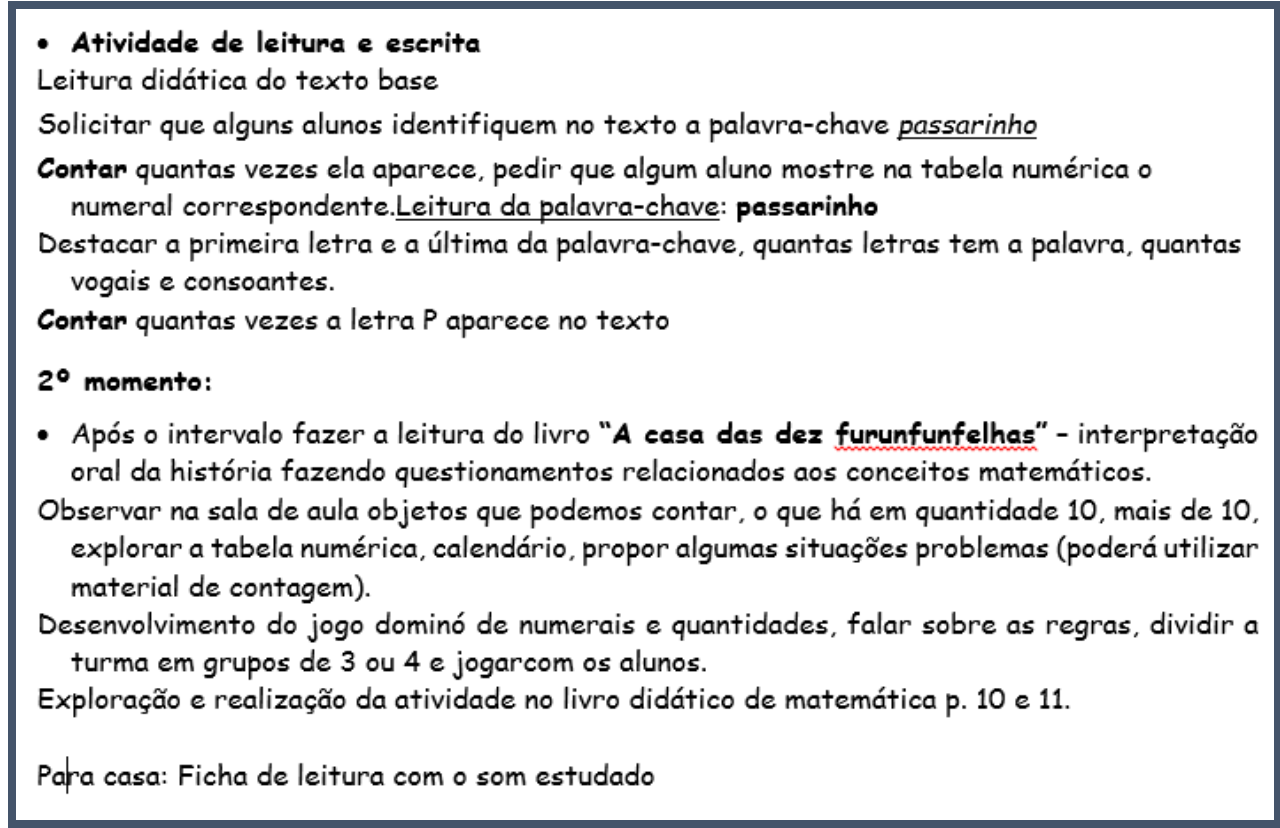

Fonte: Arquivo da pesquisadora, 2015

Mesmo que não de forma intencional ou consciente, no plano de trabalho estavam previstas situações em que a ação de quantificar estava presente e todo esse conjunto de situações poderia contribuir para aprendizagem da criança, (VERGNAUD, 1990). A questão que não era levada em conta referia-se ao tempo de aprender e a ação da criança nesse processo, pois antes do intervalo, na exploração do texto-base na aula de Português, foram propostas algumas situações que poderiam ter 
sido mais exploradas após o intervalo. No entanto, para esse momento, definido no plano como "aula de matemática", o que vimos foi a proposta de exploração do livro "A casa das dez furunfunfelhas", com a previsão de fazer questionamentos relacionados aos conceitos matemáticos e outras atividades como explorar a tabela numérica, o calendário, o dominó e ainda uma atividade no livro didático de matemática.

O que indagamos não é sobre a atividade em si, mas como a alfabetizadora pensa no tempo que será necessário para que a criança se aproprie da atividade e a realize de forma consciente, de modo a conseguir criar estratégias de resolução que mobilizem os conceitos exigidos em cada situação? E como nos lembra Muniz (2016) ${ }^{24}$, sobre a compreensão do processo de aprendizagem:

\footnotetext{
é mais que um intervalo único para a construção da aprendizagem, do conceito de número, implica também a visão de um processo cíclico e recursivo, de ir e vir, de retomada em diferentes e sucessivos momentos, em situações distintas e gradativamente mais complexas, trazendo inclusiva a noção de campo conceitual de construção do número natural pela criança e regular e gradativamente se insere em situações que o fazem mobilizar e movimentar seu conceito de número nos mais diferentes contextos e momentos.
}

Esse foi um dos pontos de discussão em um dos encontros de estudo. É importante ressaltar que na aula não se realizavam todas as atividades previstas e uma queixa comum a todas as professoras era que "não deu tempo", "as crianças fazem tudo devagar". Essas falas indicavam que precisávamos saber mais sobre o significado de alfabetização e sobre os procedimentos que articulassem melhor as diferentes e distintas atividades, sem a tradicional fragmentação das atividades e da construção conceitual.

Diante dessas observações realizadas em março, no encontro de estudos, colocamos em discussão o significado da alfabetização em matemática e iniciamos pelo conceito de número, pois não iríamos interferir na lógica sequencial de trabalho com os conteúdos. Apresentamos ao grupo algumas situações resultantes de pesquisa em que crianças de escola pública, em condições semelhantes as vivenciadas pelas crianças da escola, conseguiram envolver-se em situações de contagem e avançar na quantificação e na representação das quantidades, inclusive com a leitura da tabela numérica de 1 a 100 e números maiores que 100.

Disponibilizamos para o grupo algumas orientações de Bertoni (1997, 2007), Muniz (2007, 2014), Toledo (2009), Zunino (1995) e propusemos uma atividade simples e acessível a todas as crianças: fazer coleções de tampinhas. Elas iriam colecionar tampinhas, quantificá-las, registrar as quantidades individuais e as quantidades do total da sala. Mesmo reticentes e sem saber o que

\footnotetext{
${ }^{24}$ Reunião de orientação 2016.
} 
poderia acontecer, as professoras aceitaram a proposta. Esse fato nos remete as afirmações de Skovsmose (2008) sobre "zona de risco" contraposta a "zona de conforto".

Assim, o grupo inseriu no plano de trabalho a coleção de tampinhas (Figura 45). Para as turmas de $3^{\circ}$ ano em abril e para as turmas do $2^{\circ}$ ano a partir de maio. Importante lembrar que eram apenas duas aulas semanais. As aulas iniciaram em 02 de março e em 20 de abril tinham acontecido 14 aulas de matemática, o que era apenas o início do desenvolvimento dos conteúdos.

Figura 5 - Parte da sequência preparada para o $3^{\circ}$

Sequência didática: 30 ano
Duração: 15 dias $\quad$ Período: 20 a 24 e de 27 a 30 de abril de 2015
Conteúdos:
Matemática ((Veja, parece-me muito conteúdo para 04 aulas - 2 aulas semanais??))
1. Sistema de numeração decimal.
2. Problemas envolvendo centena, dezena e unidade.
3. Sequência numérica até 100.
4. Escrita dos números por extenso.
5. Estimativa.
6. Noções de adição.
7. Formas geométricas planas.
Objetivos:
- Realizar a contagem de números até 100, observando as regularidades da sequência com o apoio
da tabela numérica, estabelecendo relação entre número e quantidades;
- Resolver situação problemas envolvendo unidade, dezena e centena adicionando-lhe a ideia de
juntar e acrescentar.
- Escrever o nome dos números por extenso;
Estratégias pedagógicas:
18.Exploração dos números no calendário e tabela numérica.
19.Formação de agrupamentos de dez em dez ate 100, associando os amarrados e os soltos.
20.Resolução de situações problemas e de diversas atividades escrita.
21. Exploração da coleção de tampinhas

Observação: Destaca-se em negrito um questionamento da pesquisadora sobre a quantidade e a diversidade de conteúdos para duas semanas. Fonte: Arquivo da pesquisadora, 2015.

Nas turmas de $3^{\circ}$ ano, as atividades com a coleção de tampinhas iniciaram já com o registro em tabelas (Figura 6). Observamos que nessas turmas as atividades eram mais sistemáticas, pois as crianças cursaram o $2^{\circ}$ ano na escola, então, eram, de acordo com as coordenadoras, mais preparadas e poderiam ser mais exigidas. 
Figura 6 - Recorte do Plano de Trabalho

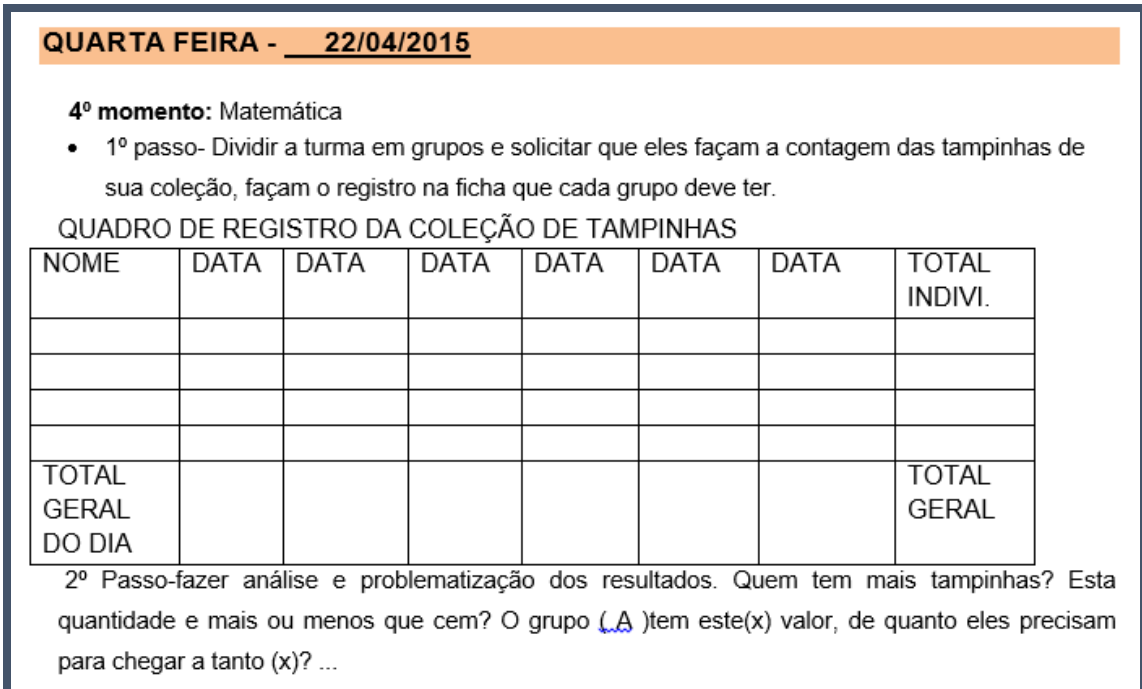

Fonte: Arquivo da pesquisadora, 2015.

Como o potencial das crianças ainda era desconhecido pelas professoras, o trabalho tornouse muito complicado, pois as crianças traziam as tampinhas e as professoras tinham de conferir com cada uma as quantidades individuais e depois ajudar no registro das quantidades dos pequenos grupos e registrar na tabela. Isso fez com que essa atividade ocupasse mais tempo do que o que era esperado pelas alfabetizadoras. Na figura 7 , tem-se as atividades do $2^{\circ}$ ano.

Figura 7 - Recorte do Plano de Trabalho para o $2^{\circ}$ ano maio 2015 


\section{* terca - FeIRA $12 / 05 / 15$}

* 20 momento

$\checkmark$ Relembrar a proposta feita no inicio da aula de fazer uma coleção de tampinhas.

$\checkmark$ Apresentar aos alunos uma coleção (tampinhas, palitos, cartas, figurinhas, bilas, canudos) e dizer que você não sabe quantos tem, por isso precisa da ajuda deles para contar.

$\checkmark$ Dividir a turma em 4 ou 5 grupos e distribuir uma quantidade indeterminada de objetos da sua coleção para que os alunos contem e registrem essa quantidade em uma folha. A professora irá acompanhar os grupos para observar as estratégias de contagem utilizadas pelos grupos.

$\checkmark$ Após a contagem, cada grupo irá apresentar o resultado e registrar no quadro o numeral.

$\checkmark$ Observando os resultados dos grupos registrados no quadro fazer os questionamentos:

- Quantos objetos o grupo 1 contou, o grupo 2, $03 . .$. ? - Que grupo contou mais, qual contou menos? - Houve grupos com a mesma quantidade? - Que número indica a maior quantidade? - Que número indica a menor quantidade?- E agora, como vamos fazer para saber quantos objetos tem no total?

$\checkmark$ Deixar que os alunos apresentem as soluções.

$\checkmark$ Lançar o desafio da estimativa: Se juntarmos os objetos de todos os grupos, quantos teremos no total?

$\checkmark$ Registrar no quadro a estimativa de cada grupo para que no final da contagem possa fazer a comparação entre as estimativas e o resultado real.

((Será que não é bom dá um tempo para que eles tentem encontrar o total? Usem estratégias próprias como proposto o objetivo $3 . . . .0$ professor pode acompanhar os grupos sem pressa para ver o que vai acontecer.))

$\checkmark$ Escrever no quadro a operação que será realizada ex: $25+32+28+37$. ((Esperar um pouco))

$\checkmark$ Fazer junto com os alunos a adição dos objetos de todos os grupos da seguinte forma, ex: o grupo 1 contou 25 objetos e o grupo 2 contou 32, então temos $25+32$. Explicar que eu já tenho 25 e por isso não preciso contar de novo essa quantidade, para adicionar a outra quantidade 32 basta continuar contado a partir do numero que vem depois do 25 e assim sucessivamente com os valores dos demais grupos até terminar de fazer todas as somas e chegar ao resultado final.

$\checkmark$ Questionar como se escreve o número, localizar na tabela, escrever como se lê, e ver qual grupo que acertou na estimativa ou mais se aproximou do resultado real.

* Para casa: Atividade no livro de matemática p. 52 e 53

Observação: Em negrito estão as nossas observações sobre a quantidade de atividades e a "pressa" em concluir sem dar tempo a criança. Fonte: Arquivo da pesquisadora, 2015.

Nos encontros de sexta-feira, insistimos em afirmar que seria interessante dar mais liberdade às crianças e tentar fazer com que um ajudasse o outro na contagem. Para fundamentar nossas intervenções, trouxemos algumas indicações da Teoria de Vygotsky (2000) e da Teoria dos Campos Conceituais de Vergnaud (1990). Mesmo assim, a imagem da matemática como algo difícil e da criança como alguém que ainda está distante deste conhecimento, somada à visão do professor como o único responsável em garantir o ensino, não possibilitava o intercâmbio de conhecimentos entre as crianças. Isso sobrecarregava as professoras. Ao atentarmos para o fator tempo, tentamos tranquilizar o grupo, discutimos as muitas possibilidades de exploração das operações durante a ampliação da coleção de tampinhas. Por mais paradoxal que possa parecer, muitas coisas aconteciam com as crianças e desmobilizavam as professoras. 
Figura 8 - A atividade de nomear cada objeto contado

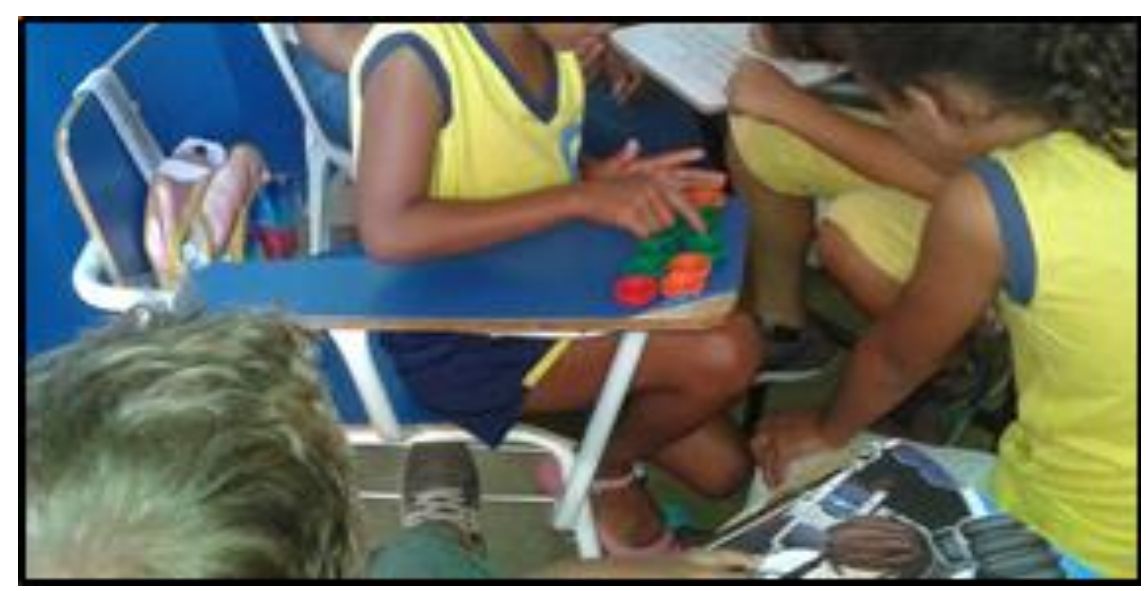

Fonte: Arquivo da pesquisadora, 2015.

As situações envolviam e encantavam as crianças, assim elas desejavam mais e mais, conversavam e ficavam eufóricas (Figuras 8 e 9). Diante dessa atitude, as professoras ficavam angustiadas, pois, de certa forma, o "domínio da sala" fugia de suas mãos.

Figura 9 - Contagem em pequenos grupos

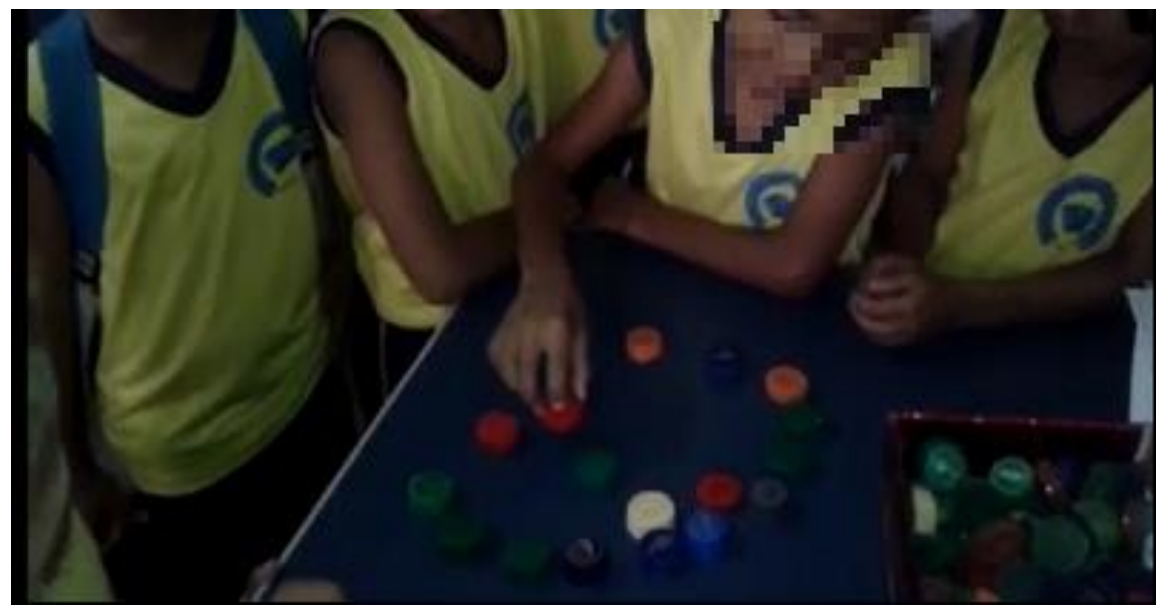

Fonte: Arquivo da pesquisadora, 2015.

A fim de diminuir a angústia e o cansaço provocado pela necessidade de acompanhar cada grupo na contagem das quantidades, pensamos juntas em como dar mais autonomia para as crianças, como dividir as nossas tarefas com elas. No avançar do trabalho com a coleção de tampinhas, que se estendeu de abril a julho, foram criadas situações de sistematização, como instrumento de registro escrito das possíveis aprendizagens que estariam acontecendo. Exploramos os quadros de registro feitos pelos pequenos grupos e o quadro de registro da turma: 
Figura 9 - Atividade elaborada pelas professoras do $3^{\circ}$ ano

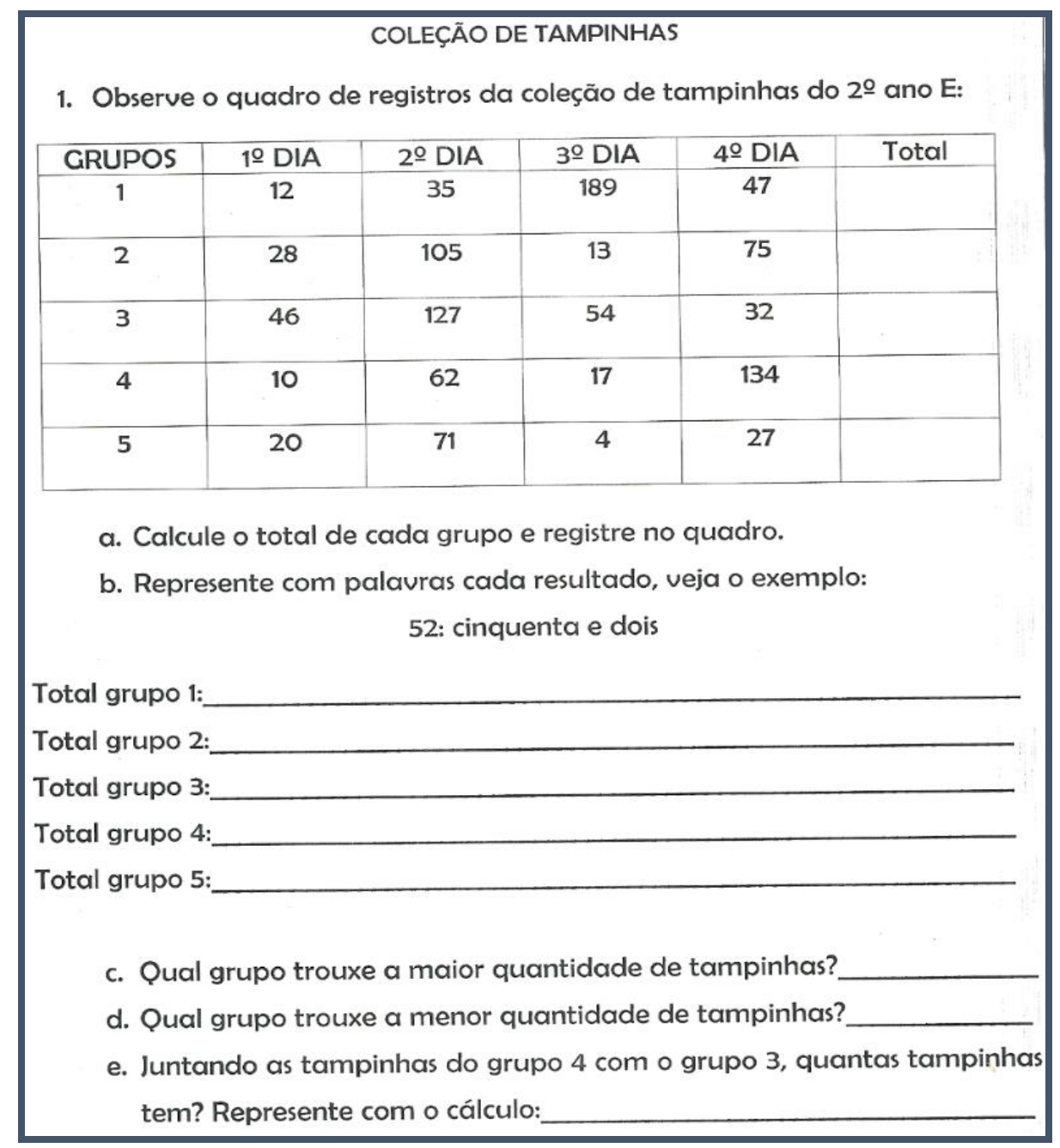

Fonte: Arquivo da pesquisadora, 2015.

As atividades continuaram durante os meses de abril, maio, junho e foram retomadas em julho, após o recesso de 04 a 12 de julho ${ }^{25}$, pois ao mesmo tempo que acontecia a contagem das tampinhas, conseguimos trabalhar com o conceito de unidades e dezenas e com as operações de adição e subtração com as tampinhas agrupadas de dez em dez e utilizadas como recurso de apoio à contagem.

A dinâmica da escola não dá muito tempo para "parar e pensar", um dia após o outro as coisas acontecem de forma muito rápida, difícil de acompanhar o ritmo frenético e ainda se equilibrar na tensão permanente de desestabilizar algumas concepções sobre a matemática, seu ensino e sua aprendizagem que interferiam na ação das professoras e coordenadoras. Respeitamos os nossos ritmos e as crianças nos ajudaram a avançar. Como elas não têm "amarras", expressavam espontaneamente as suas hipóteses sobre o nome dos números. E, como não foram impostos limites

\footnotetext{
${ }^{25}$ A segunda unidade estava prevista para terminar em 31 de julho.
} 
na quantidade de tampinhas, aconteceu de um menino em uma turma do $2^{\circ}$ ano trazer mais de 500 tampinhas. Todas ficaram eufóricas sem saber muito bem o que fazer naquela situação. Fomos obrigadas, então, a ajudar as crianças a dizer os nomes dos números além do 100. Ampliamos a tabela numérica que ficava afixada na sala e a princípio era até 50, depois passou a ser até 100 e depois até 200, contrapondo o currículo que propunha apenas até 20.

Mesmo sem afixar um cartaz (Tabela Numérica) com os números até 500 ou mais, deixamos claro qual a lógica de constituição das palavras-números oferece maior dificuldade entre o 10 e o 20, pois elas não expressam, em sua escrita, a composição aditiva. Por exemplo, de 1 a 10 as palavras-números mostram-se como algo novo: um, dois, três, quatro, cinco, seis, sete, oito, nove e dez. Depois do 20, tem-se 21 (vinte e um), em que o "e" faz o papel do sinal + (mais) e evidencia a composição aditiva entre o vinte e o um, compondo o 21.

Após observar essa característica na sequência do 20 ao 30, daí em diante o dificultador é aprender o nome das dezenas exatas, por exemplo, entre o 20 e o 100, tem-se as palavras: vinte, trinta, quarenta, cinquenta, sessenta, setenta, oitenta, noventa. Observa-se que o trinta inicia com as mesmas letras que o três (3 dezenas), o quarenta com as mesmas letras que o quatro (4 dezenas), o cinquenta com as mesmas letras que o cinco (5 dezenas), o sessenta com as mesmas letras que o seis (6 dezenas) e assim sucessivamente. Como dissemos, as palavras-números entre o 10 e o 20 são mais complexas em Português. O nome do 11 (onze) poderia ser algo próximo de "dez e um", o doze de "dez e dois", o treze de "dez e três", o quatorze de "dez e quatro", o quinze de "dez e cinco".

A partir do dezesseis a criança encontra maior apoio na língua materna, pois a palavranúmero dez- e- seis $=$ dezesseis, expressa melhor a composição aditiva $(10+6)$, ocorre o mesmo com o dezessete, o dezoito e o dezenove. Ao chegar ao vinte, a criança precisa da ajuda do adulto para falar o nome do número. Isso irá ocorrer em todas as dezenas exatas. Temos resultados de pesquisas interessantes que nos ajudam a melhor compreender esse processo, como em Rangel (1992), Zunino (1995), Kamii (1990), Bertoni (1987, 2007) e Muniz (2007, 2014).

Quando, em um dos encontros de estudo e discussão, conversamos com as alfabetizadoras sobre o apoio que a língua materna poderia oferecer à constituição da linguagem matemática, foi algo que elas julgaram inovador, pois ainda não tinham se atentado a essa especificidade e não viam o nome do número como uma palavra que precisava ser aprendida e, por isso mesmo, ensinada de algum modo. O diálogo das professoras nesse encontro revelou esse novo entendimento e como elas já mostravam ter domínio das técnicas de ensinar a leitura das palavras, logo se animaram em 
adaptar ou criar técnicas para ensinar a leitura das palavras- número. Isso contribuiu muito para as crianças avançarem.

Especificamente em Bertoni (2007), em uma produção destinada à formação de professores dos anos iniciais, encontramos uma síntese sobre como ocorre o processo de enumeração. Esse material foi colocado à disposição das alfabetizadoras. A autora chama a atenção para o fato de que as crianças apreciam decorar a cadeia numérica verbal e que "por volta dos dois anos, sabem "recitar" de 1 a 10 ou até mais." (BERTONI, 2007, p. 14). Ela afirma ainda que a alfabetizadora poderá usar a cadeia numérica verbal como instrumento auxiliar na aprendizagem dos números, desde que observe:

A aprendizagem da enumeração verbal dos números não pode se resumir a uma simples memorização de uma sequência de palavras ordenadas. Essa aprendizagem decorada é necessária no início da apropriação dos primeiros termos da cadeia, a saber: as unidades de 1 a 9 , as dezenas e o nome dos números de 11 a 15 . Fora isso, a criança deve descobrir e aplicar as regras linguísticas que sustentam a organização do sistema. (BERTONI, 2007, p. 14)

Apoiada nas ideias Delhaxhe e Godenir (1992), professores belgas, que fazem estudos sobre a construção de ideias matemáticas na Educação Infantil, Bertoni (2007) nos diz que é preciso observar que a cadeia numérica verbal:

- apresenta termos arbitrários (palavras da cadeia), estabelecidos por mera convenção, como um, dez, treze, quarenta, cem.

- apresenta termos que têm uma expressão aritmética, em que a quantidade é expressa por uma decomposição aritmética dos termos usados.

- apresenta uma estrutura que supõe a memorização de termos e de sua ordem, mas igualmente supõe a compreensão de regras de formação dos números expressas por uma decomposição. (BERTONI, 2007, p. 14-16)

No entanto, essa pesquisadora adverte também que a aprendizagem da enumeração verbal dos números não pode se resumir a uma simples memorização de uma sequência de palavras ordenadas, mesmo, que essa aprendizagem decorada seja necessária no início da apropriação dos primeiros termos da cadeia, a saber: as unidades de 1 a 9 , as dezenas e o nome dos números de 11 a 15. O processo de enumeração que, segundo a autora, seria a utilização das palavras-número para quantificar, isto é, para estabelecer precisamente a quantidade de objetos ou o número de elementos contidos numa coleção, é uma atividade que envolveria a compreensão e a coordenação de diversas competências, assentando-se sobre quatro pontos fundamentais:

1. A utilização ordenada dos nomes da cadeia numérica: as palavras da cadeia numérica devem ser pronunciadas numa ordem permanente. 
2. A correspondência única: para enumerar ou contar corretamente, é preciso não contar duas vezes o mesmo objeto e não esquecer nenhum. Cada objeto deve estar pareado a uma palavra, e a uma só, da cadeia numérica.

3. A organização da ordem de contagem (invariância ou conservação do número): a sucessão na qual os objetos da coleção devem ser contados não tem importância, mas é necessário que a criança saiba distinguir os que já contou dos que ainda deve contar.

4. O princípio cardinal: Contar não é somente ir dizendo os nomes dos números e aplicálos, um após o outro, aos elementos. Contar é quantificar. O último número-palavra pronunciado designa a quantidade de objetos contidos na coleção. Essa última etiqueta, atribuída ao último objeto, tem um significado especial: ela nos informa a quantidade de elementos da coleção. Em termos matemáticos, ela nos informa qual é o cardinal da coleção. (BERTONI, 2007, p. 14-16)

Com apoio nessas indicações, afirmamos e reafirmamos para o grupo de trabalho, em nossos espaços de discussão, reflexão e problematização, que o que estávamos fazendo era alfabetização. Algo que para nós, algumas vezes, parece simples e óbvio, para a criança ainda é novo e precisa ser aprendido. Mesmo que as palavras-números sejam utilizadas em seu convívio social, escrevê-las ou identificá-las em um cartaz são outras aprendizagens e exigirão tempo. Aos poucos foram inseridas, nos planos de trabalho, indicações sobre como explorar a leitura e aproximar a criança da linguagem matemática.

Os resultados deste primeiro projeto, Coleção de Tampinhas, foram importantes para nossas aprendizagens e para embasar as possíveis mudanças, o que não evitaria as oscilações que continuaram acontecendo a cada nova exigência de enfrentar um conteúdo de matemática. Entretanto, iniciamos com dúvidas quanto à evolução das crianças na contagem, na denominação dos números, na escrita dos números e chegamos ao mês de julho com a certeza de que elas conseguem e têm muita disposição para aprender. Ao mesmo tempo, vimos que precisamos de tempo para a leitura, para o registro das nossas aprendizagens, para a elaboração de nossas aulas, de modo a realizar a seleção de atividades, a experimentação dos recursos didáticos, o estudo das atividades propostas no livro didático e a avaliação do que é proposto para ser ensinado e do que é aprendido pelas crianças.

\subsection{DA COMPREENSÃO DO SISTEMA DE NUMERAÇÃO DECIMAL ÀS OPERAÇÕES ARITMÉTICAS}

Entendemos que, na atividade de colecionar tampinhas, as crianças quantificaram, compararam e agruparam quantidades e, nessas ações, estiveram presentes as ideias das operações de adição - quando acrescentavam mais tampinhas as suas coleções ou juntavam as quantidades de dois grupos -, de subtração - quando comparavam quantidades, ou calculavam o que faltava para 
completar determinada quantidade -, de multiplicação - quando agruparam de 10 em 10 para trabalhar o conceito de dezena e a professora questionava quantos grupos de 10 era preciso para ter, por exemplo, 3 dezenas, o que poderia ser representado por 3x10 (3 grupos de 10) - e de divisão, com a ideia de medição ao pensar em quantos grupos de 5 tampinhas temos em 25 tampinhas ou distribuir um total de tampinhas para alguns participantes do grupo.

Atentamos ao que indica o documento Elementos Conceituais e Metodológicos para definição dos Direitos de Aprendizagem e Desenvolvimento do Ciclo de Alfabetização $\left(1^{\circ}, 2^{\circ}\right.$ e $3^{\circ}$ anos) do Ensino Fundamental, ao referir-se à contagem no Ciclo de Alfabetização:

A contagem é um elemento importante no processo de aprendizagem das operações,
principalmente nas operações do campo aditivo (adição e subtração). Sugere-se estimular a
criança na contagem de objetos dispostos um a um, de forma organizada e também
dispostos de forma desorganizada, que requer dela a elaboração de uma estratégia para que
um mesmo objeto não seja contado duas vezes. Gradativamente, ela percebe que o
agrupamento facilita a contagem. As atividades de contagem com objetos agrupados são
também exploradas na aprendizagem de algumas ideias da multiplicação. (BRASIL, 2012,
p. 71)

Desse modo, seria possível explorar as ideias das operações em atividades presentes no próprio projeto de coleção de tampinhas. Mas, para que isso acontecesse, seria necessário olhar para os conteúdos, assim como para as proposições, para as situações e ações dos sujeitos de modo integrado e não de modo compartimentado. Nas conversas com as alfabetizadoras foi evidenciada a ideia de que a coleção de tampinhas era uma atividade voltada para a contagem e a aprendizagem da sequência numérica e que, para aprender/ensinar as operações, seria necessário pensar em outras situações e, ainda, que a realização de continhas dependia do conhecimento das unidades e dezenas.

Respeitamos esse modo de ver e buscamos trazer elementos teóricos e metodológicos em nossos momentos de discussão que ajudassem a superá-lo. A nossa ação de pesquisa e formação estava sempre em movimento de acordo com a necessidade. Vimos, naquele momento, que deveria ser colocado em foco o estudo do sistema de numeração decimal e das operações.

Indicamos às alfabetizadoras a leitura de Toledo (2009) para o estudo das operações, pois, além dos aspectos conceituais trabalhados pela autora, esse livro faz parte da Biblioteca do Professor - PNBE e fica disponível na sala de leitura na escola. Encontramos também, na sala de leitura, no Volume 17 da Coleção Explorando o Ensino - Matemática, uma discussão sobre o trabalho com as operações nos anos iniciais em que Mandarino (2010) apresenta algumas importantes indicações:

Se as operações fundamentais forem bem-conceituadas e se os alunos superarem dificuldades de cálculo, que alguns costumam arrastar até a vida adulta, alcançaremos um ganho expressivo para a melhoria do desempenho matemático de nossas crianças, jovens e 
adultos. [...] Explorar os diversos significados das operações fundamentais tem sido considerado essencial para a boa compreensão dessas operações. Em que consiste essa preocupação? Ela nos pede para explorarmos as várias situações em que essas operações podem intervir. Tal exploração vai contribuir para que o aluno adquira a capacidade de decidir que operação deve mobilizar, pelo conhecimento das relações entre os elementos da situação. Isto vai além de levar o aluno, apenas, a aprender a fazer cálculos envolvendo os números que aparecem em uma dada situação. (MANDARINO, 2010, p.118)

Além das indicações dessa pesquisadora, externamos no grupo nossa preocupação com o reducionismo conceitual de que trata Muniz (2009), que ocorre quando os diversos significados das operações não são devidamente explorados e a escola trabalha um conceito para cada operação, o que pode ter como consequência a falta de habilidade em resolver situações problemas. Essas indicações nos levaram a refletir sobre os objetivos para o trabalho com o sistema de numeração decimal e as operações, previstos no documento Direitos de Aprendizagem e Desenvolvimento do Ciclo de Alfabetização ( $1^{\circ}, 2^{\circ}$ e $3^{\circ}$ anos) do Ensino Fundamental:

\footnotetext{
- Ampliar progressivamente o campo numérico, investigando as regularidades do sistema de numeração decimal para compreender o princípio posicional de sua organização (dez unidades agrupadas formam uma dezena, dez dezenas agrupadas formam uma centena, dez centenas agrupadas formam um mil etc.)

- Elaborar, interpretar e resolver situações-problema do campo aditivo (adição e subtração), utilizando e comunicando suas estratégias pessoais, envolvendo os seus diferentes significados.

- Elaborar, interpretar e resolver situações-problema do campo multiplicativo (multiplicação e divisão), utilizando e comunicando suas estratégias pessoais por meio de diferentes linguagens e explorando os diferentes significados. (BRASIL, 2012, p.71-76, grifo nosso)
}

No texto do documento esses objetivos estão desdobrados em aprendizagens que se espera sejam iniciadas no $1^{\circ}$ ano, aprofundadas e ampliadas no $2^{\circ}$ e $3^{\circ}$ ano, coerente com o princípio de que a alfabetização não ocorre no $1^{\circ}$ ano. Esses objetivos e seus desdobramentos foram discutidos com as alfabetizadoras em um dos encontros de formação.

Lerner Zunino (1996) apresenta interessantes resultados de pesquisa que nos fizeram pensar na complexidade de um conteúdo que compõe o currículo dos anos iniciais. Esse currículo, às vezes, é resumido ao ensino das unidades e dezenas de modo isolado, como se aprender o que é unidade e o que é dezena fosse suficiente fazer a criança aprender a conhecer a série numérica além do 10 , ler e escrever os números com mais de dois algarismos com compreensão do valor posicional dos algarismos no registro simbólico das quantidades.

Rabelo e Curi (2014), para investigar as aprendizagens e as dificuldades dos alunos com o sistema de numeração decimal, propuseram aos alunos de quintos anos, de seis escolas das redes estadual e municipal da Cidade de São Paulo, questões abertas construídas pelos participantes de 
um grupo de pesquisa liderado pela professora Edda Curi - parte do programa Observatório da Educação, financiado pela Capes e itens divulgados pelo Inep. Os resultados indicaram que:

- Muitos alunos ainda escrevem o número por justaposição, apesar de frequentarem a escola há cerca de cinco anos.

- Mesmo descontextualizados, números de menor ordem de grandeza são mais facilmente tratados pelos estudantes do que números que envolvem várias ordens de grandeza.

- Os alunos não se apropriaram da grandeza da ordem da unidade do milhar.

- Os itens que apresentam números com zeros intercalados tiveram um percentual de erros significativamente maior. (RABELO; CURI, 2014, p. 81)

Esses resultados são preocupantes, pois foram envolvidos no estudo 385 alunos do quinto ano de seis escolas. Como justificar que essas crianças tenham permanecido cinco anos na escola, em que a matemática integra o currículo em todo esse período, esse conteúdo aparece em todos os anos, com progressivo aumento de complexidade, e ainda se encontram esses resultados?

No instrumento de avaliação diagnóstica que aplicamos em maio de 2015, que será analisado no próximo capítulo, foi possível identificar as crianças que ainda estavam em processo de entendimento da escrita do número.

Item 04: Associar a denominação do número à sua respectiva representação simbólica

Faça um X na alternativa do número TRINTA E DOIS.
(A) 23
(B) 32
(C) 203
(D) 302

\begin{tabular}{|c|l|l|l|l|l|l|}
\hline \multirow{2}{*}{ Item } & \multicolumn{3}{|c|}{ Indicador } & \multicolumn{5}{c|}{ Percentual de erros } \\
\cline { 3 - 7 } & & $\mathbf{2}^{\mathbf{0}}$ ano 1 & $\mathbf{2}^{\mathbf{0}}$ ano 2 & $\mathbf{2}^{\mathbf{0}}$ ano 3 & $\mathbf{2}^{\mathbf{0}}$ ano 4 & $\mathbf{2}^{\mathbf{0}}$ ano 5 \\
\hline \multirow{3}{*}{04} & $\begin{array}{l}\text { Associar a denominação do } \\
\text { número à sua respectiva } \\
\text { representação simbólica. } \\
\text { (32) }\end{array}$ & $11,7 \%$ & $13 \%$ & $0 \%$ & $39 \%$ & $30,4 \%$ \\
& & & & & & \\
\hline
\end{tabular}

Esse item teve como objetivo avaliar a habilidade de associar a denominação do número à sua respectiva representação simbólica. A palavra-número trinta e dois deveria ser lida e traduzida para a sua representação simbólica (32). Pesquisas mostram que essa é apenas uma fase na construção da escrita dos números. Sugerimos às professoras identificar quais foram as crianças e iniciar um trabalho com as fichas escalonadas sugeridas por Muniz (2014).

Entendemos que a compreensão das propriedades do sistema de numeração decimal é fundamental, pois, como afirma Viana (2014): 
[...] um dos alicerces do processo de letramento consiste em promover a reflexão sobre as propriedades que estruturam os sistemas de números e de escrita alfabética. Se há jogos e sequências didáticas concebidos para o desenvolvimento da consciência fonológica, também os há no sentido da contribuição para a "consciência numérica", que ocorre quando a criança consegue lidar livremente com os números, inclusive operando com eles, ciente das propriedades do SND que mobiliza em suas ações. (VIANA, 2014, p. 9)

E esse entendimento nos levou a pensar em propostas de trabalho que promovessem a aprendizagem dos conceitos implicados no sistema de numeração decimal. Nesse aspecto, concordamos com Muniz, Santana, Magina e Freitas (2014) ao afirmarem que:

Associar a quantidade de grupos aos algarismos não é o suficiente para a aquisição pela criança, em alfabetização, das estruturas fundantes do Sistema de Numeração Decimal, pois, além de decimal, o sistema é posicional. O posicionamento, assim como o agrupamento, deve figurar na proposta pedagógica como uma forma de regra de jogo. (MUNIZ, et al, 2014, p. 28)

Esses pesquisadores defendem uma proposta pedagógica que se apoie numa estrutura lúdica que faça emergir os conceitos matemáticos:

Nessa interlocução entre o lúdico e os conceitos, o aluno pode conceber a ideia da posição
como elemento fundamental na representação das quantidades numéricas do Sistema de
Numeração Decimal posicional. Assim é que vemos a importância dos algarismos no
registro das quantidades, tanto das quantidades soltas (menores que dez) quanto dos grupos
de dez. Um objetivo essencial para a aprendizagem no processo de alfabetização
matemática é, portanto, associar a representação material e o registro simbólico por meio da
utilização posicional dos algarismos. (MUNIZ, et al, 2014, p. 28)

Ao aderir às proposições desses autores, vivenciamos com as alfabetizadoras o Jogo Forme 10, que possibilita a contagem de um em um, as somas das quantidades obtidas a cada etapa do jogo, a comparação das quantidades de cada equipe e, principalmente, ações específicas como: os agrupamentos de dez em dez, as trocas e o posicionamento, essenciais na aprendizagem das características e das regras do Sistema de Numeração Decimal.

As professoras das turmas de $2^{\circ}$ e $3^{\circ}$ ano abraçaram a proposta do mesmo modo. O "Jogo Forme 10" foi realizado nas turmas de $2^{\circ}$ ano e a prioridade foi dada aos conceitos de unidade e dezena e a operação de adição e subtração, nas turmas de $3^{\circ}$ ano, além de retomar os conceitos de unidade e de dezena, foram formados grupos de 100 para explorar a centena. Vale ressaltar que o material manipulável para formar os agrupamentos, nas turmas de $2^{\circ}$ ano, foram as tampinhas e nas turmas de $3^{\circ}$ ano iniciamos com as tampinhas e depois as professoras resolveram mudar para o material dourado, quando introduziram a centena. Isso, pelo que observamos, não trouxe problemas, pois o avanço na contagem parece ter animado muito as crianças. 
Figura 10 - Resolvendo operações e mobilizando conceitos no Jogo Forme 10

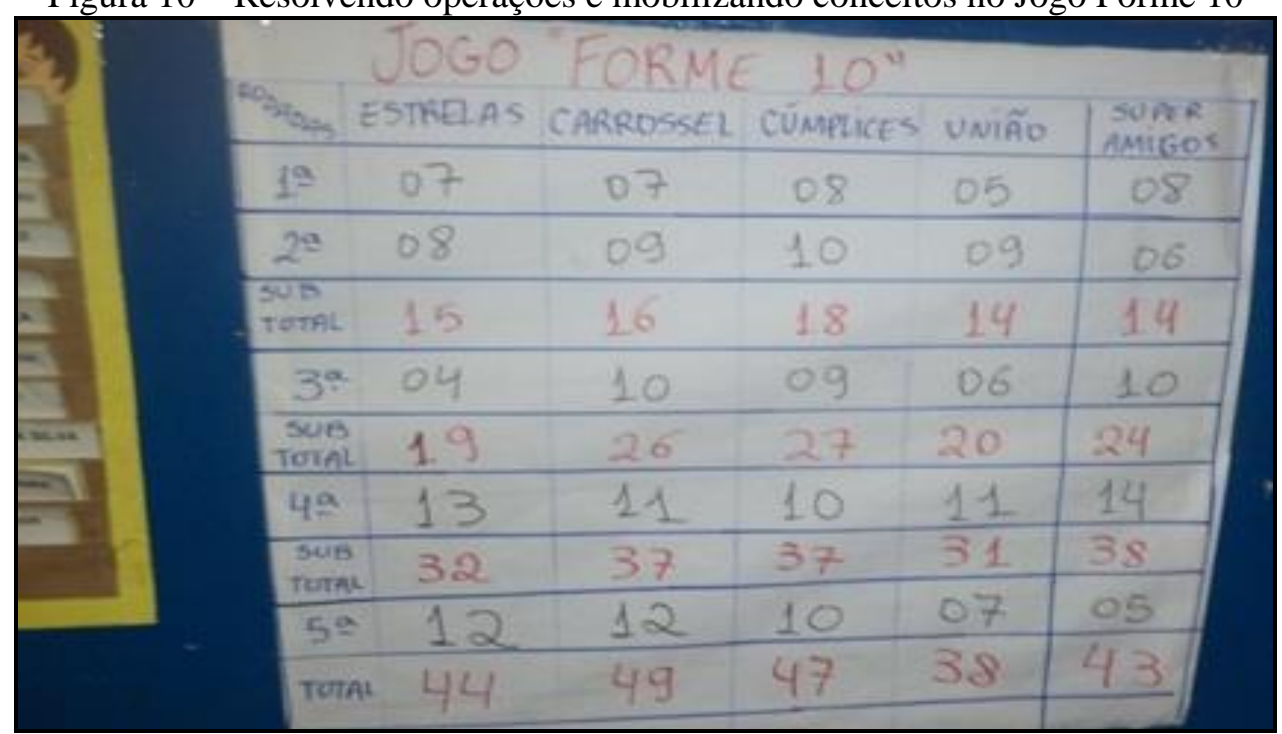

Fonte: Arquivo da pesquisadora, 2015.

Insistimos sobre a necessidade de dar tempo à criança, principalmente nas turmas de $2^{\circ}$ ano, para organizar os grupos de 10. A professora precisava estar junto aos pequenos grupos para auxiliar nos registros. A consulta à tabela numérica tornou-se uma constante entre as crianças que se ajudavam para identificar a quantidade contada, agrupar o dez, identificar o número e buscar a escrita desse número na tabela numérica.

Ao assistirmos as aulas e observarmos essa movimentação das crianças, conversamos com as professoras nos momentos de coordenação individual e, aos poucos, elas compreenderam essa dinâmica das crianças em sala. Essa constatação impactou no modo como as professoras viam a aprendizagem, ou seja, o envolvimento das crianças na busca de informação que as auxiliassem a entender o que era proposto pela professora parece ter sensibilizado no sentido de entender que elas estavam envolvidas e em busca de aprender.

Aos poucos, os materiais manipuláveis tornaram-se essenciais nas aulas e o seu uso deixou de ser motivo de "desordem". Esse foi um ponto de discussão nos encontros de formação: o necessário uso dos materiais manipuláveis como apoio à aprendizagem dos conceitos matemáticos.

É interessante destacar que mesmo com a vivência das operações presentes no "Jogo Forme 10", havia um desejo de realizar um estudo específico sobre as operações: as ideias, os algoritmos, os sinais, o nome e o significado de cada termo. A análise desse estudo e das aprendizagens das professoras será apresentada no próximo capítulo.

Após o encontro de formação, o trabalho com as operações tornou-se mais fluido e menos tormentoso. A operação de subtração, com e sem reserva, não trouxe estranhamentos, pois agrupar e desagrupar o "dez" já não era problema para as crianças. O registro escrito tornou-se mais familiar e 
o uso dos símbolos matemáticos já era feito de modo mais tranquilo. As crianças estavam se apropriando da linguagem matemática, apoiadas no desenvolvimento conceitual e procedimental. Para auxiliá-los, as alfabetizadoras afixaram cartazes com informações importantes sobre o nome e sinal de cada operação estudada.

Além das situações de contagem, da exploração do sistema de numeração decimal e das operações de adição e subtração no Jogo Forme 10, uma atividade bem ilustrativa do processo de alfabetização foi o desenvolvimento do Jogo do 2, proposto por Bertoni (1987, 2007), em que a criança, nas ações sobre o material e nas representações escritas propostas no Jogo, se aproxima de uma das ideias da multiplicação que é mais explorada nos anos iniciais: a adição de parcelas iguais. Após ser vivenciado pelo grupo de alfabetizadoras no encontro de formação, esse jogo foi inserido no plano de trabalho e fomos convidados a acompanhar na sala de aula o seu desenvolvimento com as crianças.

Essa atividade caracteriza bem o processo de alfabetização, pois oportuniza a mobilização dos conceitos na ação, apoia-se na língua materna e introduz a linguagem matemática de modo bem gradual e de forma que a criança possa apreender o significado dos símbolos. Os símbolos matemáticos, com essa proposta, são apropriados pelas crianças de forma processual e tornam-se mais compreensíveis. A imagem a seguir mostra as crianças em atividade matemática no Jogo do 2.

Figura 11 - Jogo do 2 em grupo e registro nas fichas

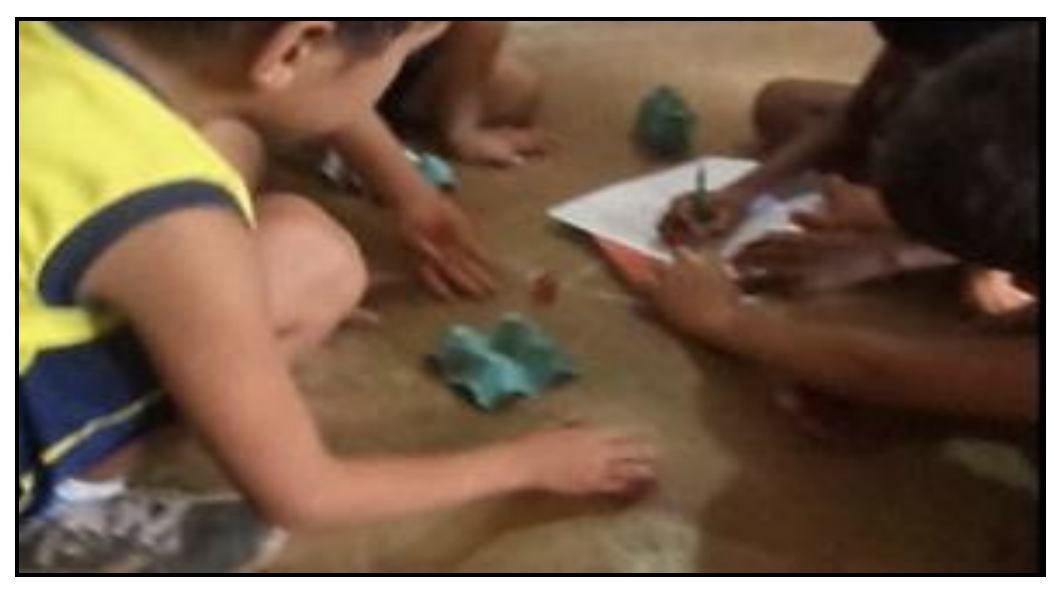

Fonte: Arquivo da pesquisadora, 2015.

Nas atividades iniciais da aula - Figura 13, já foi possível observar que as alfabetizadoras propuseram perguntas na realização da chamada que se referem à ideia de multiplicação como configuração retangular. Essas tentativas de deslocar a aula de matemática do horário destinado a essa aula nos animava, pois era indício de que as nossas discussões desmobilizavam algumas crenças e provocavam transformações. 
Figura 12 - Proposição de perguntas referentes ao conteúdo matemático na realização da chamada

\section{DISTRIBUIÇÃO DAS ATIVIDADES}

\section{terçA-FeIRA 01/09/2015}

* Atividades de rotina: Oração, música da independência e conversa informal.

- Calendário: Que mês está começando hoje? Qual é a ordem que ele aparece no calendário? Que datas comemorativas temos no mês de setembro? (dia 7 - independência do Brasil e dia 21 dia árvore)

- Chamada: Quantas crianças vieram hoje? Se a turma estiver organizada em fileiras e cada fila tiver a mesma quantidade de carteiras, pode-se fazer a operação da adição e da multiplicação para descobrir o total de crianças.

\section{* 2o momento: Matemática}

- Voltar ao texto base para explorar as medidas utilizadas na receita (se possível levar para sala de aula uma xícara e uma colher de sopa), fazendo relação com a multiplicação e os conceitos de dobro e triplo. Partindo de questionamentos como: Se quisermos fazer duas receitas, ou seja, dois bolos o que podemos fazer? $\mathrm{R}=$ devemos dobrar os ingredientes da receita. Se formos fazer três bolos? R= devemos triplicar os ingredientes da receita. Fazer essas demonstrações utilizando as xícaras e as colheres e ir registrando as operações no quadro.

* QUARTA-FeIRA 02/09/2015

* 2o momento: Matemática

- Continuação do assunto multiplicação, dobro e triplo a partir da receita e de outros exemplos utilizando material concreto como tampinhas, canudos, lápis, etc.

- Realização das atividades propostas no livro didático páginas: 216 a 219

* Para casa: atividade de matemática envolvendo multiplicação, dobro e triplo a partir da receita.

Fonte: Arquivo da pesquisadora, 2015.

O trabalho com a multiplicação continuou na semana seguinte, o que evidenciou a compreensão da necessidade de explorar as situações por um tempo maior. A realização do Jogo do 2 foi prevista no plano de trabalho das turmas do $2^{\circ}$ ano, como podemos ver na figura 14 :

Figura 13 - Recorte do Plano de Trabalho/ operação de multiplicação 


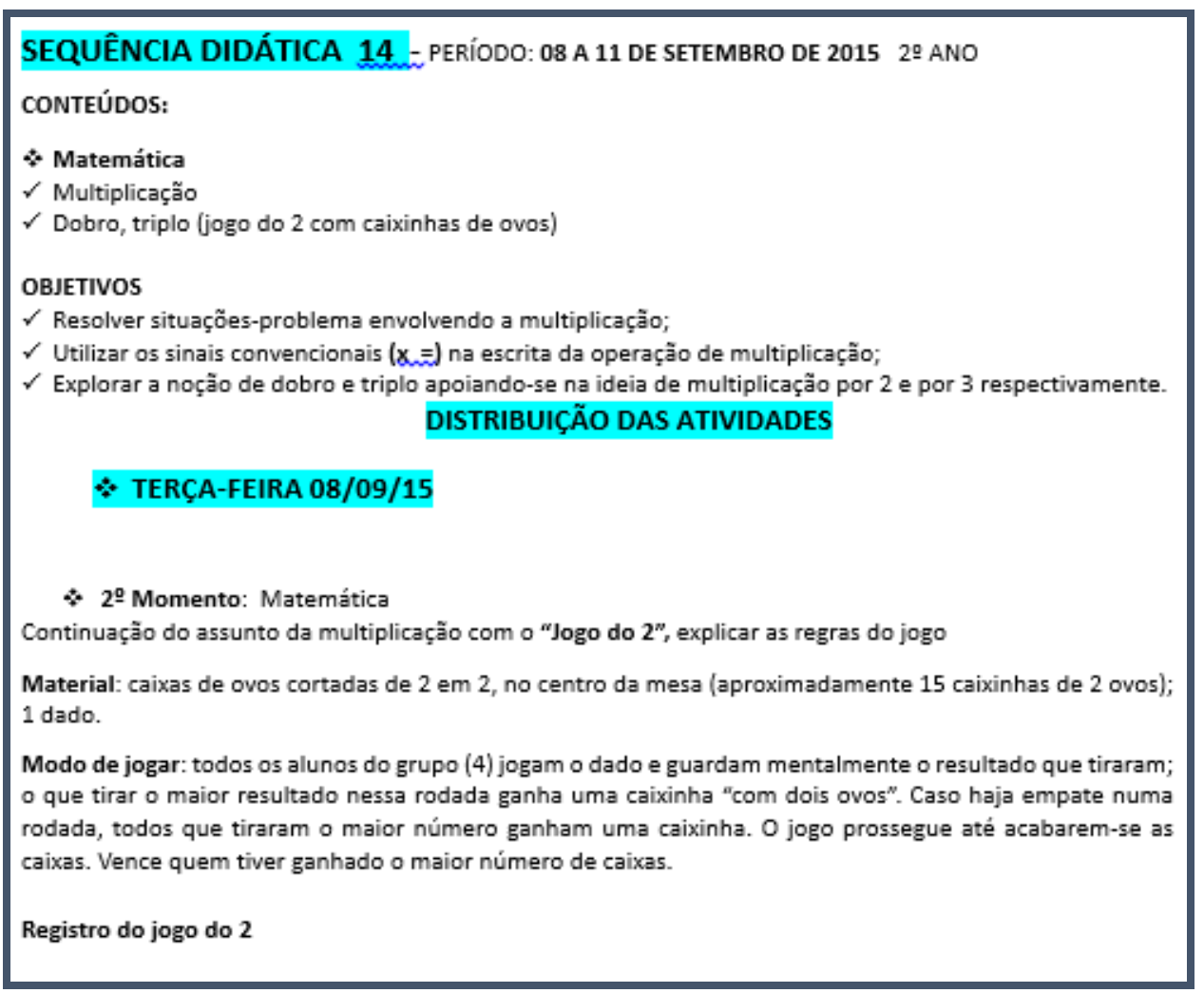

Fonte: Arquivo da pesquisadora, 2015.

Mesmo nas turmas de $3^{\circ}$ ano, que já haviam estudado essa operação no $2^{\circ}$ ano e tinham maior maturidade, as alfabetizadoras propuseram o jogo do 2, como uma forma de retomar a operação de multiplicação. As atividades do livro didático previstas nos planos n. 14 e n. 15, exploraram as outras ideias de configuração retangular e combinação de possibilidades.

Quanto à operação de divisão, é importante ressaltar que estudamos no grupo o algoritmo das subtrações sucessivas, as ideias de medida e partilha, o significado de cada termo, com base em Bertoni (1987) e Toledo (2009). Mas, nem sempre o que foi estudado é imediatamente traduzido em prática: Como ensinar a divisão ou como iniciar esse estudo em uma classe de alfabetização? Fomos convidados a assistir uma aula. No início da aula, foram entregues algumas situações problemas para explorar a ideia de repartir da divisão. A professora fez a leitura do enunciado da primeira situação e pediu que eles resolvessem. Em seguida, nos questionou:

Professora F: "sei que preciso ajudá-los a ler para compreender e que falamos sobre isso no encontro de discussão, mas como posso fazer isso?"

Pesquisadora: "vamos fazer juntas, pois eles reconhecem em você a professora". (Diário de campo. Arquivo da pesquisadora, 2015)

Neste contexto indagamos: o que sabemos sobre a complexidade da operação de divisão? Em apenas uma aula será possível resolver três situações problemas com as ideias da divisão: 
identificar o quanto tenho para ser dividido (o dividendo); em quantas partes será dividido (o divisor em situação de partilha) ou quantas vezes o divisor "cabe" no dividendo (situação de medida) e ainda quem é quociente e qual o resto (se houver)? De que lugar a criança parte para responder à pergunta do problema?

Parecia haver uma crença de que essa resposta seria automática e, de imediato, a criança usaria o algoritmo formal, colocando os números na chave da divisão e resolvendo a operação inversa da divisão. Novamente, atentamos ao fato de que estávamos em processo de alfabetização. Assim, convidamos as crianças a ler a primeira situação e sublinhar informações importantes, conforme a Figura 15.

Figura 14 - Leitura das situações-problemas

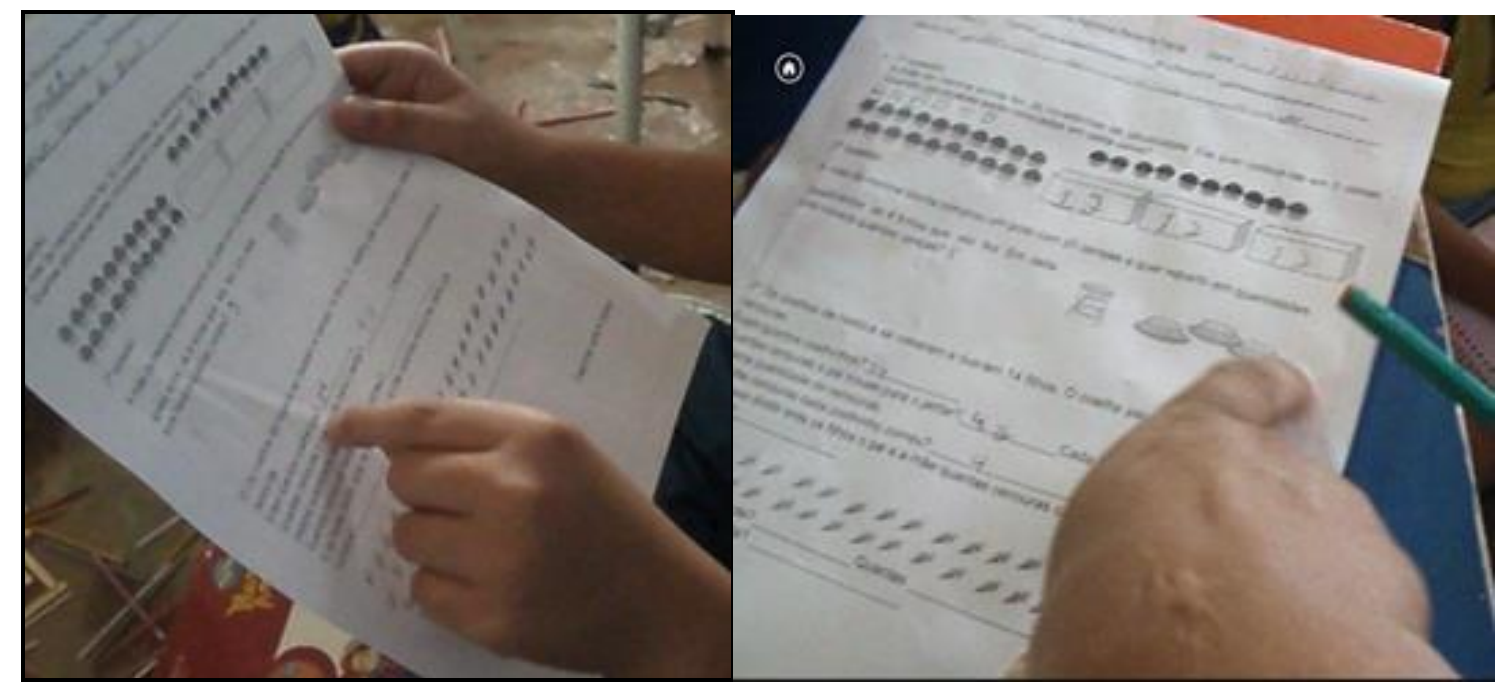

Fonte: Arquivo da pesquisadora, 2015.

Interrogamos de onde eles poderiam partir para responder à pergunta e se precisariam de material de apoio. Logo eles pediram os palitos. Também questionamos se eles preferiam trabalhar em duplas ou trios. A resposta foi óbvia: “Claro!!”. A professora imediatamente os ajudou na organização da sala e na distribuição do material. Na figura 16 vemos a manipulação do material. 
Figura 15 - Manipulação de materiais para resolver a divisão

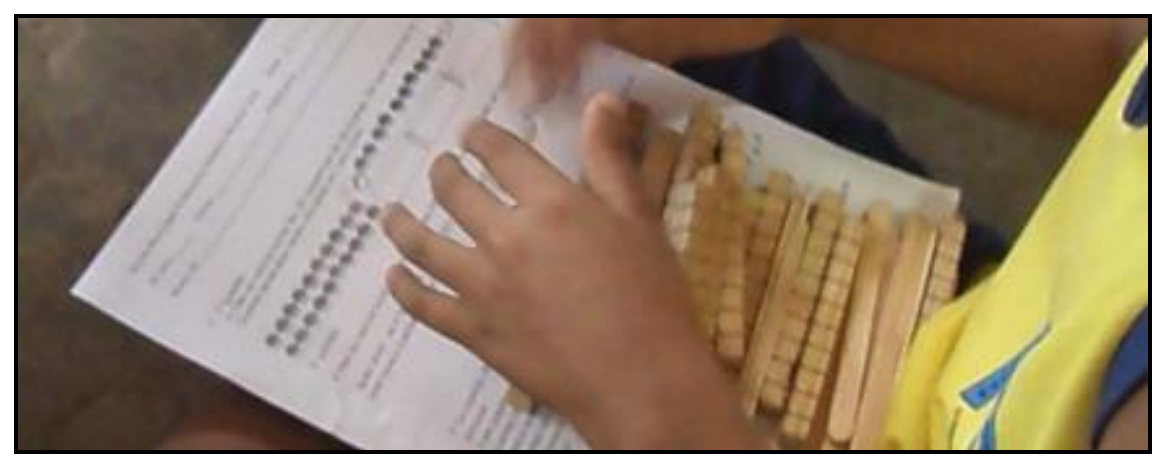

Fonte: Arquivo da pesquisadora, 2015.

Em uma das situações, a ideia era de repartir e foi necessário ir à cantina buscar pratos para que servissem de compartimento para colocar os objetos que seriam distribuídos. Em sala, junto com a professora, foi possível acompanhar e auxiliar em todo processo e observar a ação da criança. O envolvimento da turma pode ser observado na figura 17 :

Figura 16 - O processo de contar o total, distribuir e contar com quantos palitos cada prato ficou

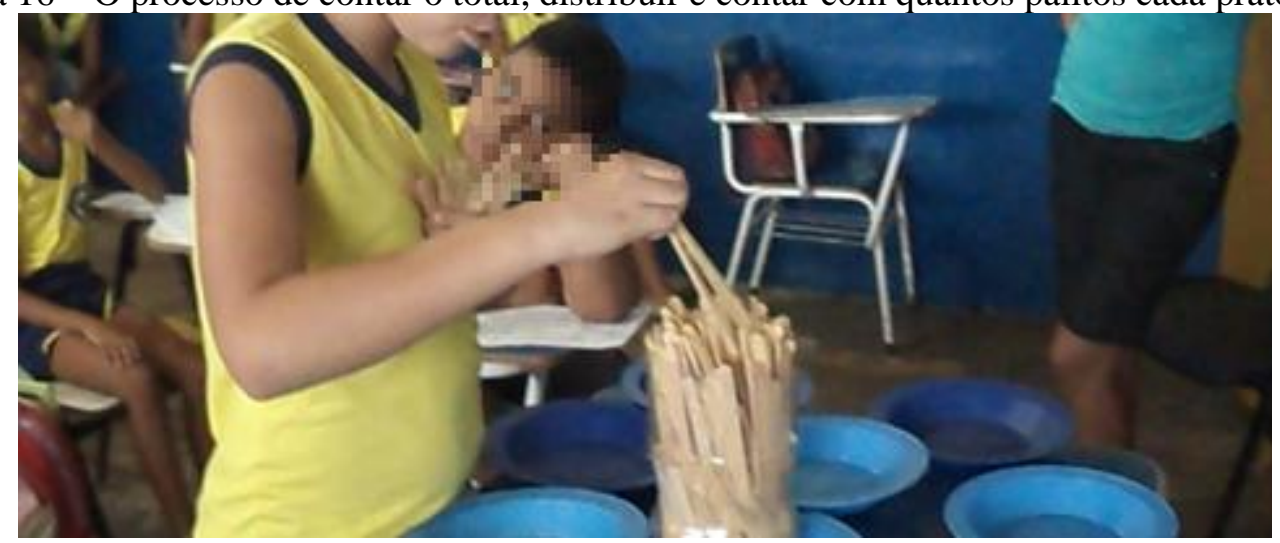

Fonte: Arquivo da pesquisadora, 2015.

Registramos a escrita das frases matemáticas, o uso adequado dos símbolos e não precipitamos o uso da chave para formalizar o algoritmo, nos apoiamos nas palavras. Escrevemos no quadro as principais frases da situação em língua materna e com uso dos símbolos matemáticos. Levamos para o momento de discussão coletiva essa ideia de como transitar da manipulação do material para a escrita da frase matemática.

Esse trabalho reforçou o nosso ânimo em problematizar as questões propostas, por meio da elaboração de perguntas. Assim, outros estudos foram desencadeados a partir de questionamentos referentes as diferentes orientações para a prática em alfabetização: 
Professora Ira - $2^{\circ}$ ano: Como posso dialogar com a criança durante o jogo? O que devo perguntar? E se for uma atividade do livro? Apenas digo: vejam na página $\mathrm{N}$ e realizem essa ou aquela atividade. Agora, ao pensar que é alfabetização, de que forma vou ajuda-los a ler o que está escrito no livro de Matemática? A aprendizagem da leitura não é só na aula de Português. (Diário de campo. Arquivo da pesquisadora, 2015)

Essas indagações foram desencadeadoras do trabalho que analisaremos na próxima seção, apresentada a seguir.

\subsection{LER, ESCREVER E PROBLEMATIZAR AS ATIVIDADES DOS LIVROS DIDÁTICOS E AS HISTÓRIAS DOS PARADIDÁTICOS}

Nesta subcategoria, foram agrupadas e analisadas as informações referentes à leitura do livro didático de matemática, adotado pela rede municipal para o ano letivo de 2015, e a exploração dos contextos das histórias infantis dos paradidáticos, indicados para a área de Português na criação de situações problemas em matemática. Essas informações foram registradas no envolvimento das alfabetizadoras, coordenadoras e pesquisadora nessas duas ações que foram destaque na pesquisa por terem desencadeado muitas discussões, reflexões sobre o trabalho na alfabetização, sobre o significado de alfabetizar e sobre as conexões entre a matemática e a leitura.

Um dos principais critérios para destacar essas duas ações foi entender como fundamental para a alfabetização a aproximação da criança aos textos em qualquer área e gênero; em nosso caso, sua aproximação dos textos em matemática. Nacarato (2009) reforça essa ideia ao afirmar que:

Os alunos precisam aprender a ler matemática e ler para aprender, pois, para interpretar um texto matemático, é necessário familiarizar-se com a linguagem e com os símbolos próprios desse componente curricular e encontrar sentido naquilo que lê, compreendendo o significado das formas escritas. (NACARATO, 2009, p.44)

Seria possível propor inúmeras situações sem necessariamente apoiar-se no livro didático? Sim. Mas, entendemos que a criança recebe os livros, das diferentes áreas de conhecimento que compõe o currículo. Esse é um material de leitura que pode ser visto como um amplificador cultural. Na área de educação matemática, pesquisas como as desenvolvidas Mandarino (2010) e Valente (2010) analisam o livro didático na organização do trabalho do professor. As tendências inovadoras nessa área como: resolução de situações problemas, história da matemática, jogos e novas tecnologias são progressivamente incorporadas ao livro didático. Ensinar a criança a ler o livro didático seria um recurso a mais para auxiliar a alfabetização matemática. 
Em nosso local de pesquisa ainda contamos com um agravante que é a falta de recursos mínimos ${ }^{26}$ como o papel ou a tinta para impressão de atividades. Esse fato obriga a alfabetizadora a escrever no quadro, o que demanda tempo e um esforço a mais da criança em processo de aproximação com a escrita. Utilizar o livro permite que a criança tenha acesso ao tex to impresso.

Ao nos inserirmos na escola, já encontramos no plano de trabalho referências ao uso do livro didático e também propostas com os paradidáticos, porque o ano de 2015 foi definido pela Secretaria Municipal de Educação como o ano da leitura. Como um dos nossos referenciais em educação matemática nos anos iniciais são os resultados de pesquisa de Smole (2001), vimos a possibilidade de aliar a leitura dos livros infantis e a alfabetização matemática como algo possível e uma oportunidade de discutir com as alfabetizadoras que a mobilização de conceitos matemáticos não precisa ficar restrita ao tempo da aula de matemática.

\subsubsection{Ler e problematizar os problemas dos livros didáticos}

A proposta de ler e problematizar os problemas do livro didático foi elaborada com dois objetivos: olhar para o enunciado da situação-problema como um texto a ser lido, principalmente no Ciclo de Alfabetização; e superar a pergunta “que conta é”, muitas vezes feita pelas crianças após a leitura de uma situação problema, realizada pelo professor.

O fato das operações terem sido criadas como recurso para auxiliar na resolução de problemas em matemática era bem conhecido, mas, mesmo assim, parecia haver uma separação: ensinamos as operações e ensinamos a resolver problemas ${ }^{27}$. Mesmo com todo trabalho de realizar operações em situações que ocorreram no Jogo do Forme Dez e no Jogo do 2, ou com o contexto das histórias infantis, na fala das professoras ainda apareciam as preocupações quanto à criança perguntar "que conta é?", nas situações em que lhes era proposta uma situação problema.

Em Muniz (2009), encontramos uma discussão a respeito desta pergunta “que conta é? ”. Ela surge sempre que as operações são trabalhadas de forma isolada, ocasião em que as crianças não criam suas próprias estratégias de resolução. A criança não atribui sentido à operação, não a associa o conceito matemático que ancora a situação proposta no contexto, e quando se vê frente a

\footnotetext{
${ }^{26} \mathrm{Na}$ escola campo de pesquisa essa falta é minimizada pela obtenção de recursos via realização de brechós, de festa junina e pela atuação da direção que agiliza as solicitações de modo a garantir que os recursos mínimos estejam sempre à disposição. Durante um ano, observamos a falta de papel e tinta poucas vezes, mas em contato com professores de outras escolas sabemos que há um racionamento de papel que, às vezes, impede o professor de disponibilizar material impresso à criança.

${ }^{27}$ Encontramos em Nilza Bertoni (2014) e em Muniz (2009) interessantes discussões sobre a diferença entre problema e situação problema
} 
um problema proposto pela professora para "treinar" um algoritmo, supostamente ensinado, não identifica neste problema um desafio que exija uma elaboração de estratégia e entende que algo uma conta? - precisa ser feito com os números que aparecem no problema.

Talvez essa preocupação fosse legítima para o ano anterior (2014) e não para o ano de 2015, pois já havíamos iniciado a proposição de situações-problemas a partir dos jogos e das histórias infantis. De toda forma, como as ações de pesquisa - formação estavam diretamente vinculadas às demandas que surgiam da prática em sala de aula, tomamos esse como um dos pontos para reflexão. Nele vimos uma ótima oportunidade para falar sobre um dos principais objetivos da alfabetização: a aproximação com a leitura em todas as áreas, inclusive a matemática. Como uma das referências para essa discussão, revisitamos os textos de Smole e Diniz (2001) que nos trazem indicações tanto teóricas quanto metodológicas sobre como aliar a leitura à matemática, principalmente por meio da proposição de situações-problemas.

Neste sentido, ainda colocamos para o grupo a afirmativa de Bertoni (2004) sobre a resolução de problemas ser, ao mesmo tempo, o objetivo e a metodologia do ensino e da aprendizagem em matemática.

O principal objetivo do ensino de matemática e a grande competência que ele visa desenvolver são, como dissemos, a capacidade de pensar e resolver situações - problema com autonomia. Isso pode ser feito pelo desenvolvimento, na escola, de atividade matemática significativa, que implique construção de estratégias e procedimentos, mobilização e busca de conhecimento. Resolver situações relaciona-se a uma série de competências matemáticas que serão desenvolvidas não antes, mas durante o processo de construção de solução, caracterizando o que se chama aquisição de conhecimento em ação. Desse modo a resolução de problemas constitui-se em objetivo e método de ensino de matemática. (BERTONI, 2004, p.5, grifos nossos)

É interessante ressaltar que desde 1997/1998, os Parâmetros Curriculares Nacionais propuseram a resolução de problemas como uma das principais tendências em educação matemática, que indicavam alguns princípios que resumimos como:

- o ponto de partida da atividade matemática não é a definição, mas o problema.

- o problema certamente não é um exercício em que o aluno aplica, de forma quase mecânica, uma fórmula ou um processo operatório.

- na resolução de problemas ocorrem aproximações sucessivas ao conceito por meio de transferências, retificações, rupturas em um processo análogo ao que se pode observar na história da Matemática.

- o aluno não constrói um conceito em resposta a um problema, mas constrói um campo de conceitos que tomam sentido num campo de problemas.

- a resolução de problemas é uma orientação para a aprendizagem. (BRASIL, 1997, p. 33)

Esses entendimentos guiaram nossa ação junto às alfabetizadoras e nos fizeram insistir em elaborar perguntas para explorar os problemas do livro didático, dar tempo para as respostas das 
crianças, incentivar a troca de informações entre elas, sem ter medo da "bagunça", ou melhor, da possível desestabilização do contrato didático clássico, há tanto tempo instituído, que isso poderia gerar. Conversamos com as alfabetizadoras sobre a possibilidade de dialogar com as crianças na aula de matemática, pois a elaboração de perguntas para problematizar os problemas e auxiliar em sua leitura e interpretação iria contribuir tanto para ampliar a habilidade de ler o texto matemático o enunciado do problema - quanto no diálogo com a criança.

Talvez esse fosse um caminho para constituir na sala de aula, na aula de matemática, uma comunidade de aprendizagem como proposto por Nacarato, Passos e Grando (2014), ao discutirem a organização do trabalho pedagógico para a alfabetização matemática.

\begin{abstract}
Os professores poderão perceber o desenvolvimento do aluno ao criar um ambiente favorável à comunicação e debates de ideias. Esse ambiente deverá fazer parte das aulas de Alfabetização Matemática, sobretudo pela forte presença da oralidade. Pode-se dizer que, nesse planejamento, a intencionalidade do professor para trabalhar as noções pertinentes ao conhecimento matemático precisa ficar explícita, deixando claro o que os alunos sabem a respeito e se compreenderam a proposta; ativar os conhecimentos prévios úteis para a compreensão da proposta; estabelecer com eles as expectativas desejadas; possibilitar que os estudantes construam seu conhecimento, evitando antecipações desnecessárias ou situações que pouco ou nada contribuem para o conhecimento já construído; escutar cuidadosamente os alunos, interpretando suas formas de raciocinar; fornecer sugestões adequadas; observar e avaliar o processo; possibilitar que os estudantes debatam sobre o assunto, cabendo ao professor encorajar a formação de uma comunidade de aprendizagem em sala de aula. (NACARATO; PASSOS; GRANDO, 2014, p. 9)
\end{abstract}

Em nossos encontros, nos horários de coordenação, durante a semana, conversamos sobre isso com as coordenadoras e as alfabetizadoras e lembramos o estudo realizado no ano anterior, durante o curso de formação - PNAIC - Matemática. Mas, algumas concepções ainda nos impediam de avançar, pois dar voz às crianças ainda era uma possibilidade de gerar a "bagunça".

Convidamos todo grupo a ler os textos contidos no livro Matemática - Coleção Explorando o Ensino- Volume 17 que, como já dissemos, estava disponível na sala de leitura. Na primeira parte deste livro, Carvalho e Lima (2010) analisam a escolha e o uso do livro didático e apontam como funções importantes do livro didático:

Para o aluno:

- favorecer a aquisição de saberes socialmente relevantes;

- consolidar, ampliar, aprofundar e integrar os conhecimentos;

- propiciar o desenvolvimento de competências e habilidades do aluno, que contribuam par aumentar sua autonomia;

- contribuir par a formação social e cultural e desenvolver a capacidade de convivência e de exercício da cidadania.

Para o professor:

- auxiliar no planejamento didático-pedagógico anual e na gestão das aulas;

- favorecer a formação didático- pedagógica;

- auxiliar na avaliação da aprendizagem do aluno; 
- favorecer a aquisição de saberes profissionais pertinentes, assumindo o papel de texto de referência. (CARVALHO; LIMA, 2010, p. 15)

E, defendem o livro didático como fonte de saberes socialmente relevantes:

O livro didático deve favorecer a aquisição de conteúdos dos grandes campos da matemática escolar: números e operações, geometria, grandezas e medidas e tratamento da informação. Ele deve tratar dos conceitos e procedimentos acumulados nesses campos matemáticos de geração em geração, e julgados importantes para a bagagem cultural de toda a sociedade.

(CARVALHO; LIMA, 2010, p. 17, grifos nossos)

Por conhecer a realidade e o contexto socioeconômico dos residentes no bairro onde localiza-se a escola, sabe-se que a renda é inferior a dois salários mínimos e, por esse motivo, a prioridade é a alimentação, o vestuário e os itens mais básicos. O investimento na compra de livros ou qualquer material de leitura é difícil. O livro-texto utilizado nas aulas talvez seja um dos poucos recursos que fazem a intermediação entre o conhecimento do senso comum e o conhecimento sistematizado.

É preciso ressaltar que em muitas salas de aula este livro é deixado de lado porque as crianças não aprenderam a ler no primeiro ano. E, assim, a leitura do livro didático é um direito negado e sobre essa temática lembramos que há um Plano Nacional do Livro e Leitura ${ }^{28}$, às vezes desconhecido e desconsiderado por muitos. Poderíamos discutir o uso do livro didático nessa perspectiva. Mas, naquele momento o que nos importava era a mudança de fonte de consulta para a seleção das atividades realizada pelas professoras alfabetizadoras. Deixaram a busca de atividades prontas em sítios da internet, nem sempre confiáveis, e em manuais de atividades que não foram avaliados por especialistas e aproximaram-se de um material que, mesmo que não seja o ideal, é um material que passou por critérios de seleção e avaliação.

Nos planos de trabalho, vimos que a ação da professora era detalhada, mas não estavam registradas as possíveis perguntas para estabelecer um diálogo com a criança e, ao mesmo tempo, orientar a leitura do enunciado dos problemas. Às vezes, as atividades do livro didático eram propostas para casa. Em casa, nem sempre a criança pode contar com a ajuda dos pais para ler o livro didático, especialmente nessa comunidade em que a maioria dos pais tem um nível mínimo de escolaridade. Outras vezes a atividade do livro era proposta como atividade de fixação.

Os possíveis questionamentos a fim de problematizar a atividade não eram registrados no plano. Pensamos na possibilidade de serem anotados em algum caderno, mas isso não era uma

\footnotetext{
${ }^{28}$ Sites para saber mais sobre o PNLL:http://www.cultura.gov.br/pnll e http://www.plataformadoletramento.org.br/em-revista/395/pnll-democratizacao-do-acesso-ao-livro-e-a-leitura-nobrasil.html
} 
prática e, de acordo com as coordenadoras, se era para ser feito em sala o melhor seria colocar no plano de trabalho. Nos momentos de coordenação individual conversamos sobre esse aspecto e rascunhamos algumas propostas com sugestão de possíveis perguntas para auxiliar na leitura de uma situação problema que aparecia no livro didático.

Figura 18 - Pasta de produções

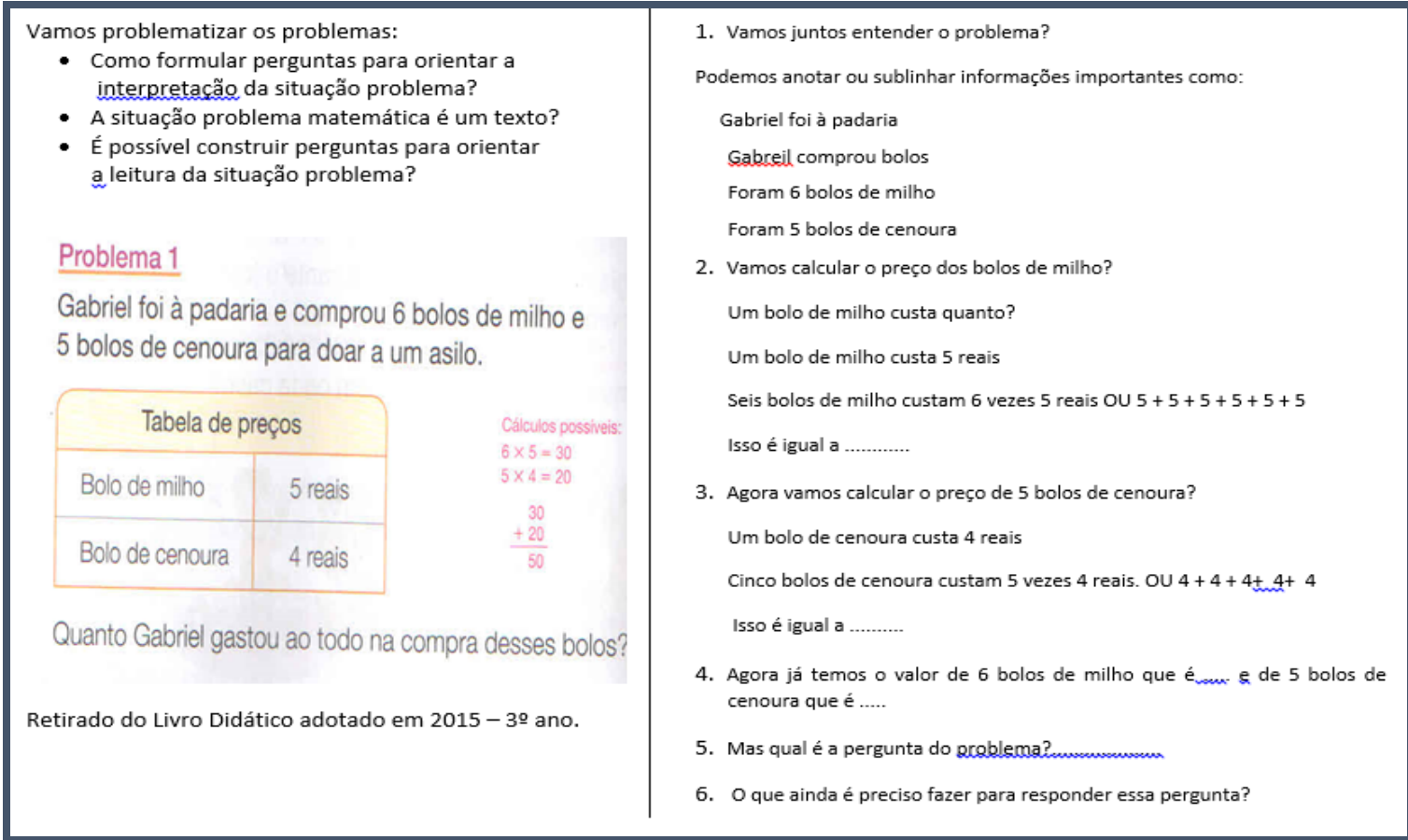

Fonte: Arquivo da pesquisadora, 2015.

Os constantes convites à reflexão desencadearam uma busca em ver no enunciado do problema, contido no livro didático, um texto a ser lido e isso provocou uma euforia entre as alfabetizadoras, revelada em falas como: "porque isso não foi pensado antes? Isso é alfabetizar!!??" (Diário de campo. Setembro de 2015). Indicamos a leitura do capítulo cinco do livro Ler, escrever e resolver problemas: habilidades básicas para aprender matemática de Smole e Diniz (2001), em que Diniz (2001) escreve sobre os problemas convencionais nos livros didáticos e analisa formas de problematizá-los.

Continuamos à disposição nos momentos de coordenação e no acompanhamento às aulas. Foi possível ver a tentativa de inserir as perguntas nos planos de trabalho produzidos naquele período, numa relação indissociável entre teoria e prática. A visão sobre o enunciado de uma situação problema como um texto matemático firmava-se, do mesmo modo que a ideia da necessidade de propor boas perguntas. Novamente em um dos momentos de coordenação 
individual, uma das coordenadoras pediu: “- por favor, escreva perguntas para problematizar essa questão do livro p. 159” (Diário de campo. Setembro de 2015).

Fizemos a leitura da situação e rascunhamos algumas possíveis perguntas. A redação das perguntas foi melhorada e, então, elas foram inseridas no plano de trabalho para orientar a problematização feita pelas professoras.

Figura 19 - Inserção de perguntas no plano de trabalho

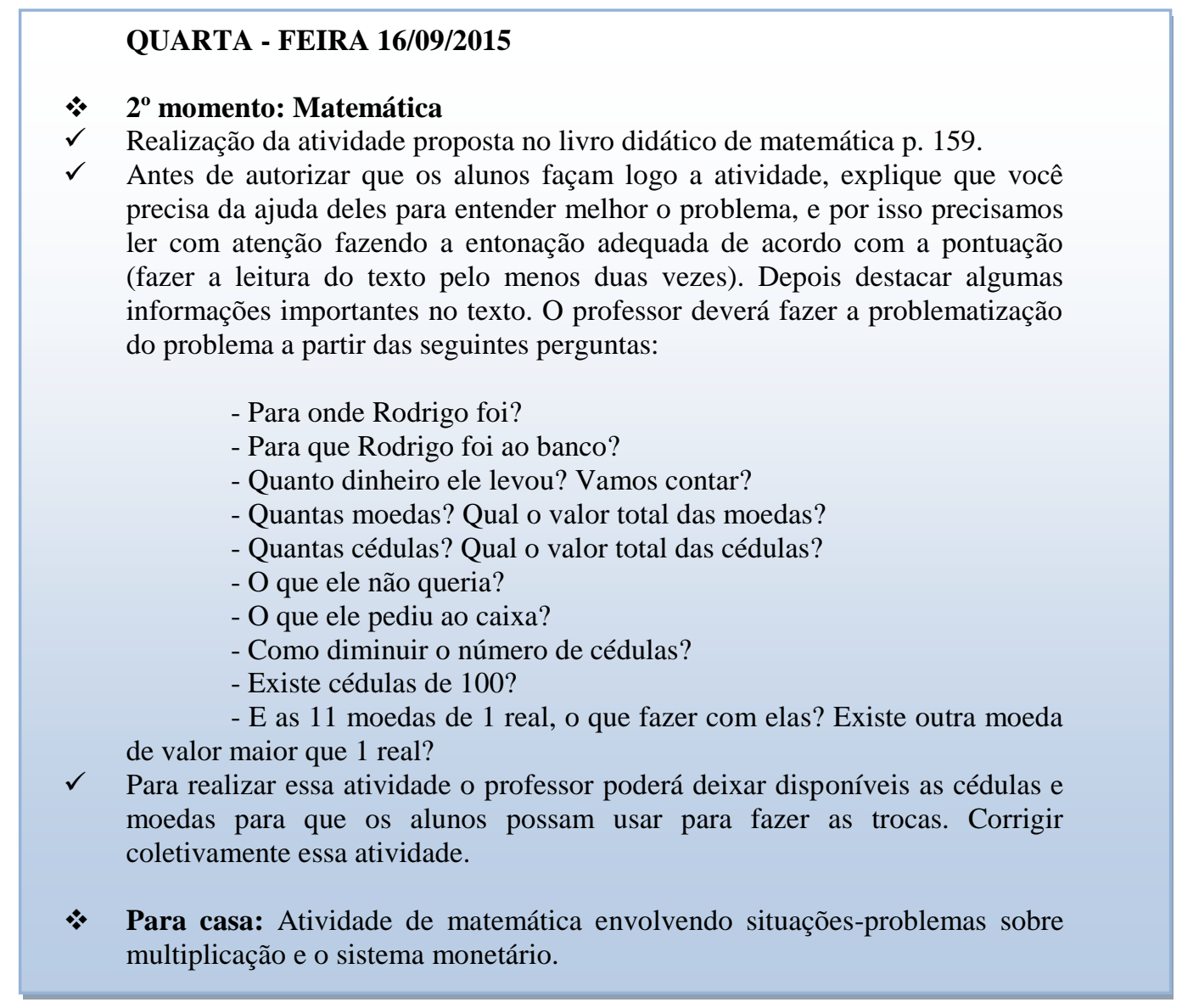

Fonte: Arquivo da pesquisadora, 2015.

Na Figura 19, observamos um detalhamento da atividade, com registro das possíveis perguntas que iriam auxiliar as crianças na leitura e interpretação do enunciado. E, na continuidade desse trabalho, foi reforçada a ideia do enunciado de uma situação-problema como um texto que é para ser lido, interpretado, problematizado, no qual são identificadas as ideias relevantes e que, quando bem compreendido e identificada a pergunta do problema, a criança estará livre para criar estratégias próprias de resolução. Nesse contexto, o que ficou mais evidente, além do interesse das crianças pelas atividades matemáticas, foi a persistência das professoras em aprender um modo 
diferente de fazer, superar as práticas anteriores em que todas as ações de ler, pensar, identificar a pergunta e "dar pistas" da operação a ser usada eram ações exclusivas das professoras.

A prática de elaborar perguntas para problematizar os problemas do livro didático despertou o grupo para a um dos principais objetivos da aprendizagem matemática que é a resolução de situações-problemas e, ao mesmo tempo, abriu a possibilidade de promover as discussões em sala de aula. Nessa direção, encontramos em Wolman e Quaranta (2006) uma análise do significado das discussões em sala de aula. De início, as autoras buscam responder à questão: O que são os momentos de discussão?

Os momentos de discussão conformam uma das modalidades que adquire a interação entre pares na sala de aula: trata-se de um intercâmbio entre todos os alunos da turma orientado pelo professor. De nenhuma maneira são "eventos naturais" da vida na aula: as discussões não podem ficar restritas às contingências de uma classe ou à espontaneidade dos alunos. (WOLMAN; QUARANTA, 2006, p. 111)

As autoras defendem a resolução de problemas e a reflexão sobre eles como centro da aprendizagem e do ensino da matemática. E a reflexão é provocada, principalmente nos momentos de discussão;

[...] frequentemente se diz que os alunos não sabem resolver problemas. Assim expressam as perguntas sobre a operação que deve ser feita e que formulam diante de um enunciado: "É de mais?" "Que conta tenho de fazer" "Tem de dividir?". Essas perguntas surgem especialmente quando faltam as palavras-chave que dão pistas ou sugerem a operação que deve ser feita. Encontramos, assim uma cena repetida na sala de aula: os alunos sabem fazer contas, mas não reconhecem em que situações é pertinente usá-las. Um exemplo disso é quando conhecem algumas tabuadas de multiplicação, mas não reconhecem as situações em que a multiplicação pode ser o caminho para a solução. Finalmente, esses conhecimentos permanecem vazios de sentido enquanto não são ferramentas mobilizáveis para resolver problemas. (WOLMAN; QUARANTA, 2006, p.112)

Wolman e Quaranta (2006) chamam a atenção para a participação determinante do professor ao organizar propostas de trabalho que tenham como atividade central a resolução de problemas e a reflexão sobre o que foi feito. Isso porque:

A aprendizagem matemática baseia-se na resolução de problemas e na reflexão sobre o que
foi feito: os procedimentos empregados e os conhecimentos envolvidos devem converter-se
em objeto de reflexão. Os intercâmbios com os colegas e o professor são aqui cruciais, isto
é, a explicitações, as confrontações e as justificativas entre os alunos são um fator de
progresso para todos. Permitem ir construindo o caminho que levará a validar o trabalho
feito. Essa atividade reflexiva enriquecerá, reciprocamente, as futuras resoluções de todos
os alunos. (WOLMAN; QUARANTA, 2006, p. 113)

A figura 61 mostra uma situação criada pelas professoras alfabetizadoras em que há uma preocupação em colocar perguntas para auxiliar na interpretação da situação-problema. Observamos 
que foram propostas apenas duas situações-problemas, o que deu mais tempo para a criança ler, identificar informações importantes e criar estratégias de solução.

Figura 20 - Atividade elaborada pelas professoras

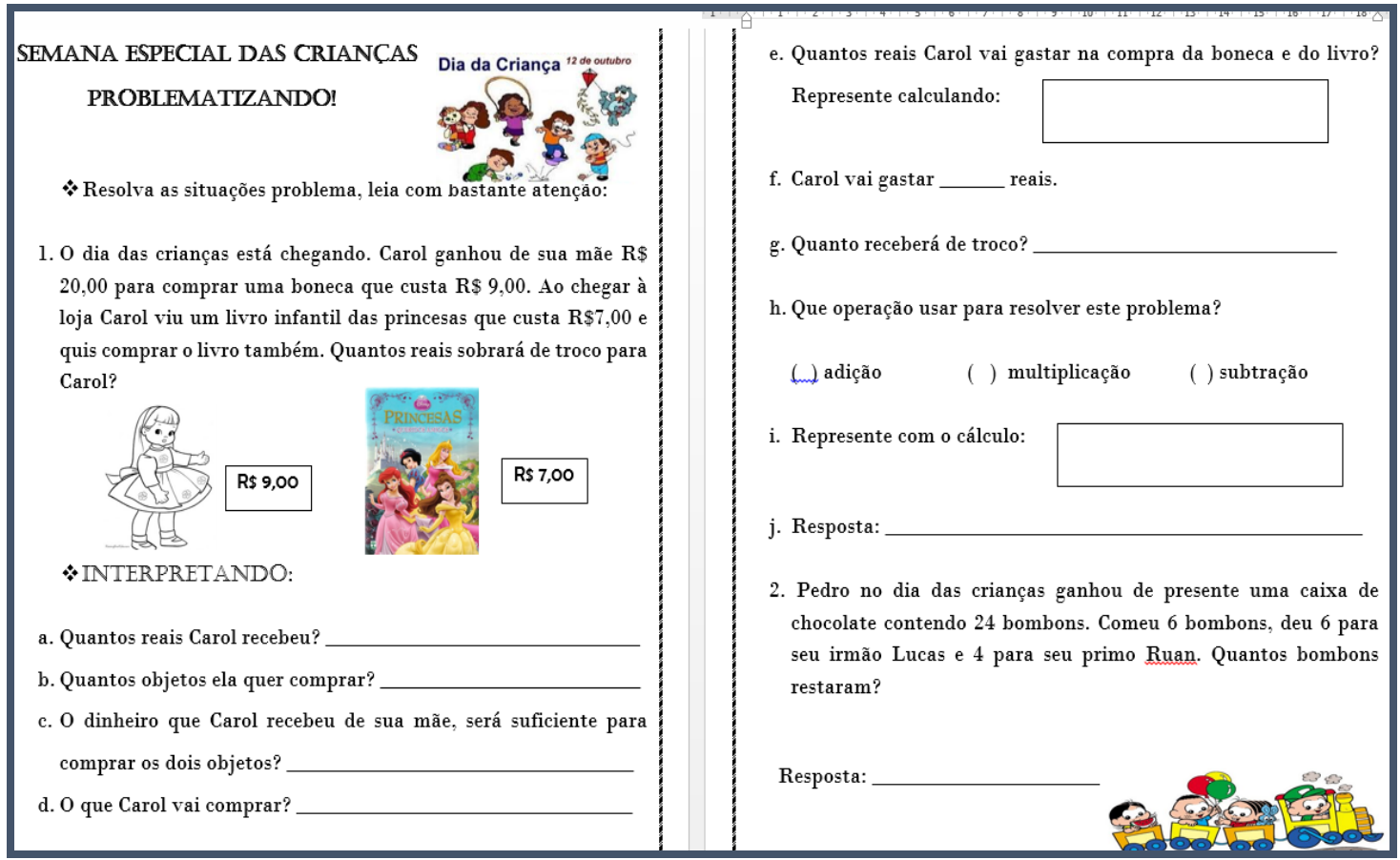

Fonte: Arquivo da pesquisadora, 2015.

Essas ideias, as vivências e as indicações teóricas e metodológicas contribuíram também para a ampliação do trabalho com os paradidáticos de português - os livros de Literatura Infantil como contextos para situações-problemas matemáticos. Novamente reafirmamos a natureza processual das muitas mudanças e a nossa persistência em manter o respeito ao tempo do outro. Com isso, assentimos que, se o grupo conseguisse avançar e propor perguntas para problematizar os problemas existentes no livro didático, de modo a gerar os momentos de discussão em sala de aula, tal procedimento seria por nós considerado como a superação da crença na falta de habilidade da criança em processo de alfabetização, de explicitar, confrontar, argumentar, criar hipóteses e soluções.

\subsubsection{Os paradidáticos de Literatura Infantil: contextos para aprender matemática na alfabetização}

Ressalta-se que, desde o início do ano, as coordenadoras externaram o desejo de explorar a relação entre a leitura e a matemática, por meio do uso dos paradidáticos da área de Literatura Infantil como contexto para trabalhar com os conceitos matemáticos. Esse desejo de aliar a leitura 
em português e a alfabetização matemática já representava um ótimo objetivo para a equipe. A superação de crenças e concepções talvez fosse menos complexa desse modo.

O que foi revelado no percurso de trabalho, desde março de 2015 , é que pareciam haver compartimentos estanques. Embora acreditando ser possível explorar os contextos dos paradidáticos, as situações eram compartimentadas, realizava-se uma operação de cada vez, as noções matemáticas permaneciam isoladas e a ação era centrada no professor. As situações extraídas dos contextos das histórias infantis só eram vistas em dois tempos de aula e não se considerava o tempo da criança. Enfim, mesmo em uma proposta de trabalho interessante, lúdica, contextualizada, as crenças e concepções sobre o ensinar e aprender matemática criavam obstáculos para a realização de um trabalho diferente.

Enquanto o trabalho com a contagem das tampinhas não foi iniciado, algumas situações simples, apoiadas nas leituras dos paradidáticos, que em sua resolução exigiam operações aritméticas elementares, foram propostas às crianças, sempre com números pequenos (menores que 20). Reiteramos aqui que a proposição de situações com números sempre menores que 20 pode ser uma evidência de como era concebido o processo de alfabetização com limitação dos desafios e isso foi desestabilizado quando se instaurou projetos como o das tampinhas, que fez com que o grupo extrapolasse os limites impostos pelo currículo vigente. E, como já dissemos, havia uma familiaridade com o eixo de Estatística e as professoras se mostravam mais à vontade para utilizar tabelas e gráficos como recursos para proposição de operações. Assim, vimos, como exemplo, as atividades com a leitura do paradidático Viviana de Pijama, na turma de $3^{\circ}$ ano, como um contexto para elaborar um gráfico de coluna com as imagens dos animais que aparecem no livro.

A análise dessa situação, como espaço para explorar os conceitos do eixo de estatística será apresentada na seção 4.4.2. Por enquanto, importa-nos ressaltar a prática de propor situações matemáticas relacionadas aos contextos dos paradidáticos: a quantidade de animais foi contada, registrada pelas crianças e representada no gráfico.

Desde o início de nossa aproximação com a equipe, insistíamos que um texto do livro paradidático poderia ser trabalhado por mais de uma ou duas semanas e que duas situações problemas, a depender do nível de complexidade, eram suficientes para um tempo de aula e seriam mais produtivas em termos de aprendizagem do que várias situações, às vezes, repetitivas e não desafiadoras.

As coordenadoras mostravam-se bem instrumentalizadas para explorar os paradidáticos, já faziam isso com tranquilidade, mas era difícil abrir mão dos exercícios, como uma forma de garantir a aprendizagem. Assim, era possível ver na mesma sequência de atividades a leitura do 
paradidático, a exploração de duas situações problemas contextualizadas e uma "lista de problemas", em que a mesma operação era repetidamente exigida em um mesmo formato. Havia uma oscilação entre o "paradigma do exercício" caracterizado por Skovsmose (2008) e a possibilidade de avançar para criar na sala de aula uma comunidade de aprendizagem como propõe Nacarato (2009).

Isso evidenciava a necessidade de tempo de estudo, de amadurecimento de ideias, de reflexão e de problematização. Assim, apenas no mês de setembro, após as discussões sobre como formular perguntas para explorar os problemas do livro didático e como elaborar e propor situações problemas, é que as equipes de alfabetizadoras do $3^{\circ}$ ano e do $2^{\circ}$ ano propuseram atividades bem diferenciadas, provocadoras de desafios para as crianças, com oportunidades de leitura e escrita e, principalmente, promotoras de aprendizagens matemática.

Nesse período já havíamos definido os livros a serem lidos e apresentados no encontro literário, cujos resultados serão analisados no próximo capítulo. E um deles foi o de Nacarato (2009) que, no capítulo II, traz indicações sobre a prática da leitura e da escrita nas aulas de matemática. E essas leituras ampliavam as ideias, o que ficava evidente nas novas propostas de trabalho. No diário de campo de 25 de setembro, registramos o Plano de Trabalho com o livro $A$ economia de Maria que foi elaborado para duas semanas. Um recorte deste plano será analisado no capítulo 4 como ilustrativo da tentativa de reorganização do trabalho pedagógico:

Figura 171 - Um resumo da história A economia de Maria

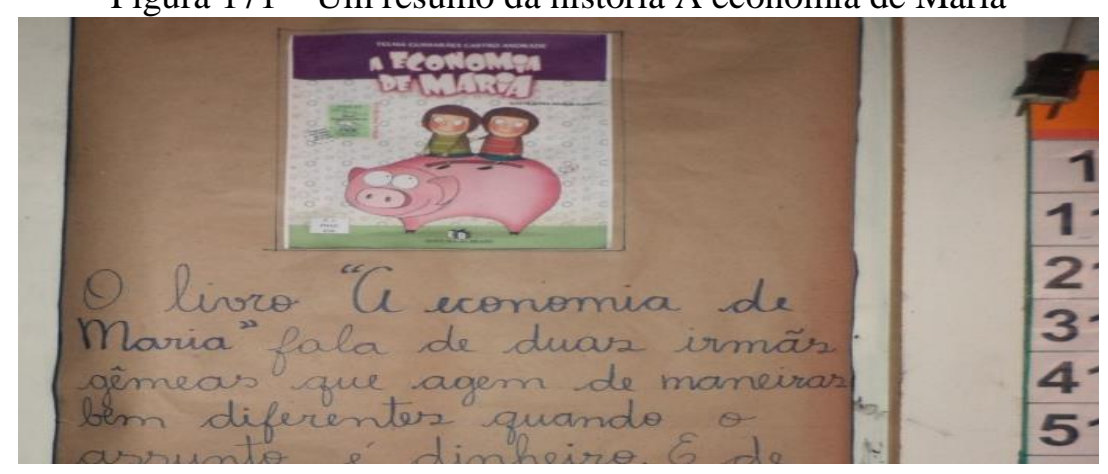

Fonte: Arquivo da pesquisadora, 2015.

Essa história abriu possibilidades de explorar as operações de adição e multiplicação e noções do sistema monetário brasileiro como mostram os conteúdos e objetivos, apresentados na figura abaixo, que foram retirados do Plano de Trabalho do $2^{\circ}$ ano.

Figura 22 - Extrato do plano de trabalho $\mathrm{n}^{\circ} 15$ 


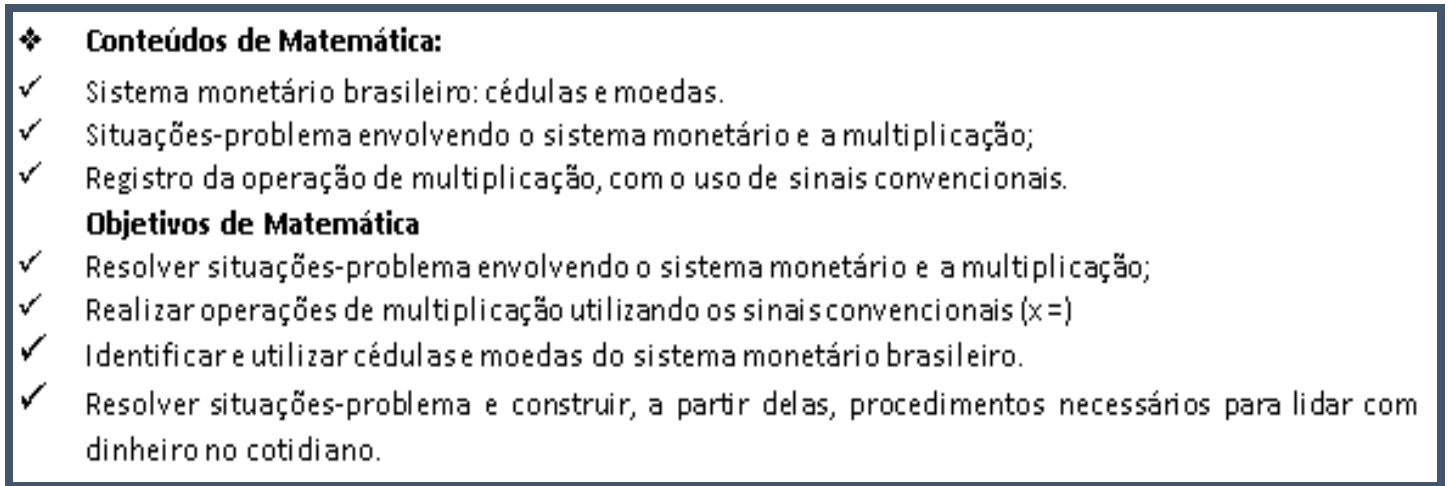

Obs.: Esses conteúdos e objetivos estão previstos na proposta curricular do município.

Fonte: Arquivo da pesquisadora.2015

As crianças foram envolvidas em atividades de produção coletiva. As perguntas foram propostas e registradas pela professora no quadro e isso resultou em uma interessante situação escrita, digitalizada e resolvida por todos. As aprendizagens e/ ou reaprendizagens reveladas pelas professoras nessas situações serão analisadas na segunda categoria, no próximo capítulo. Naquela mesma semana, vimos na aula de quarta uma proposta de produção de texto na aula de matemática.

Figura 23 - Extrato do plano de trabalho

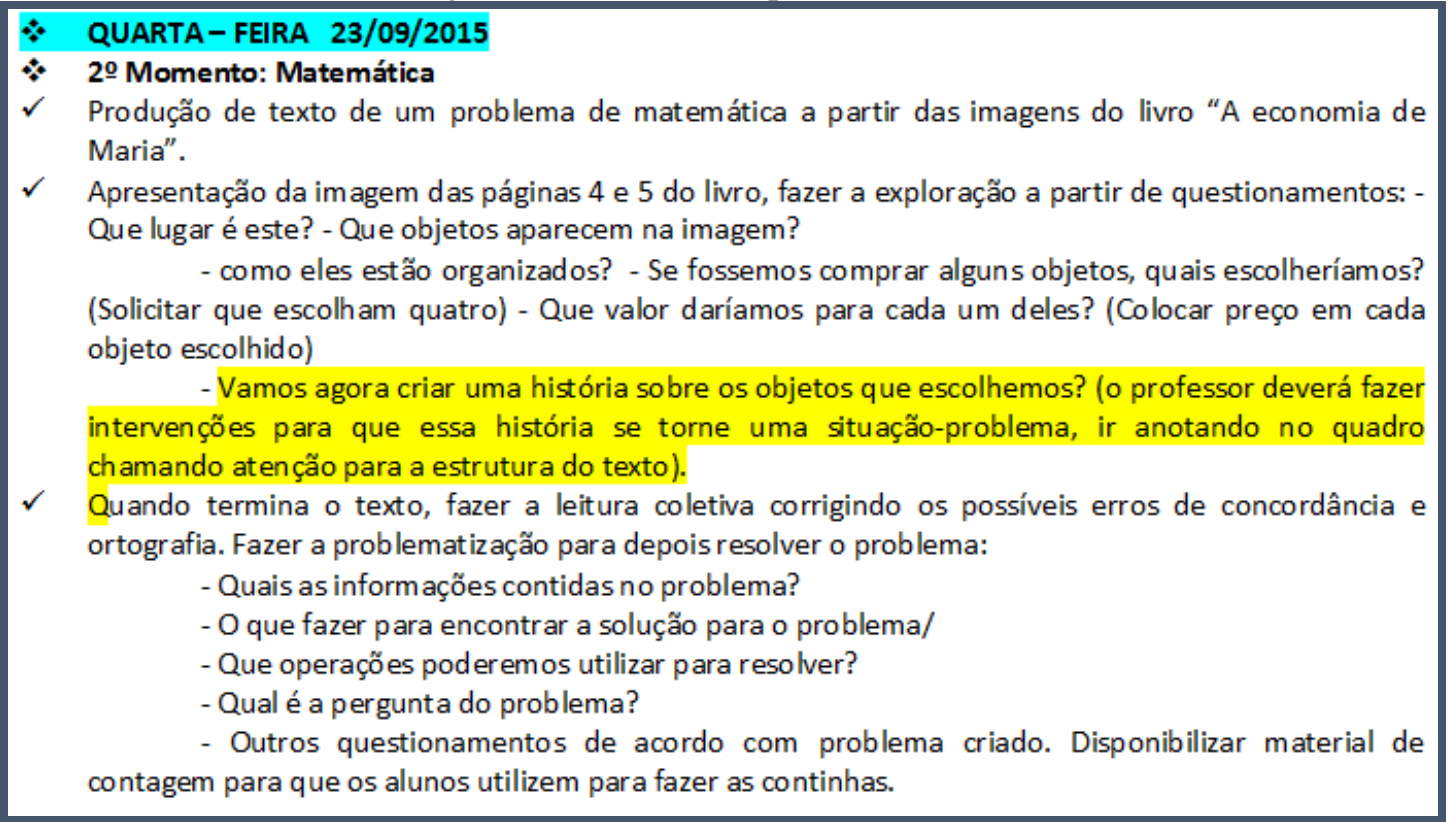

Fonte: Arquivo da pesquisadora, 2015.

A situação problema construída coletivamente foi digitada e proposta à turma como uma atividade escrita. Os registros escritos pelas crianças mostram que o interesse pela atividade matemática aumentou e criou mais sentido, provavelmente por ter sido criada com a história infantil do livro paradidático que traz em si um contexto que envolve a criança na leitura e a faz transitar entre o mundo real e o mundo da imaginação. Esse contexto pode provocar ideias em todas as áreas 
do conhecimento, mas especificamente na área de matemática tem desafiado as professoras a criarem situações problemas matemáticas.

As situações visavam explorar os conceitos estudados a cada semana. Já tinha sido estudada a operação de adição e estavam estudando a multiplicação. A situação construída coletivamente a princípio explorava a adição. Mas no depoimento da professora há o relato do caso de uma criança que ao ser perguntada que operação será usada para resolver a situação diz que é a multiplicação. A professora pergunta porquê e ela diz: "veja que temos dois produtos com o mesmo preço". Ela se referia o preço da varinha mágica e da caneta assobio, ambos custavam $R \$ 3,00$ e aos preços da borracha perfumada e lápis pisca-pisca, ambos custavam $R \$ 2,00$. A criança lembrava-se de que poderia fazer duas vezes três reais e duas vezes dois reais, por isso caberia usar a operação de multiplicação.

O mais importante a destacar nessa situação é que a preocupação com a pergunta "que conta é?" desapareceu, ou no caso das turmas de $2^{\circ}$ ano, nem chegou a existir, pois a elaboração de situações-problemas em contextos e a proposição de boas perguntas deu a criança a oportunidade de pensar, de elaborar estratégias próprias de resolução e de usar os algoritmos convencionais como instrumentos de registro das operações, sem no entanto, eliminar ou diminuir o poder de riscar bolinhas, riscar pauzinhos, usar os dedos como poderosos recursos de apoio à contagem e de agilização do pensamento. A seguir, expomos algumas produções da turma da professora Lu.

Figura 24 - Produção de Jad

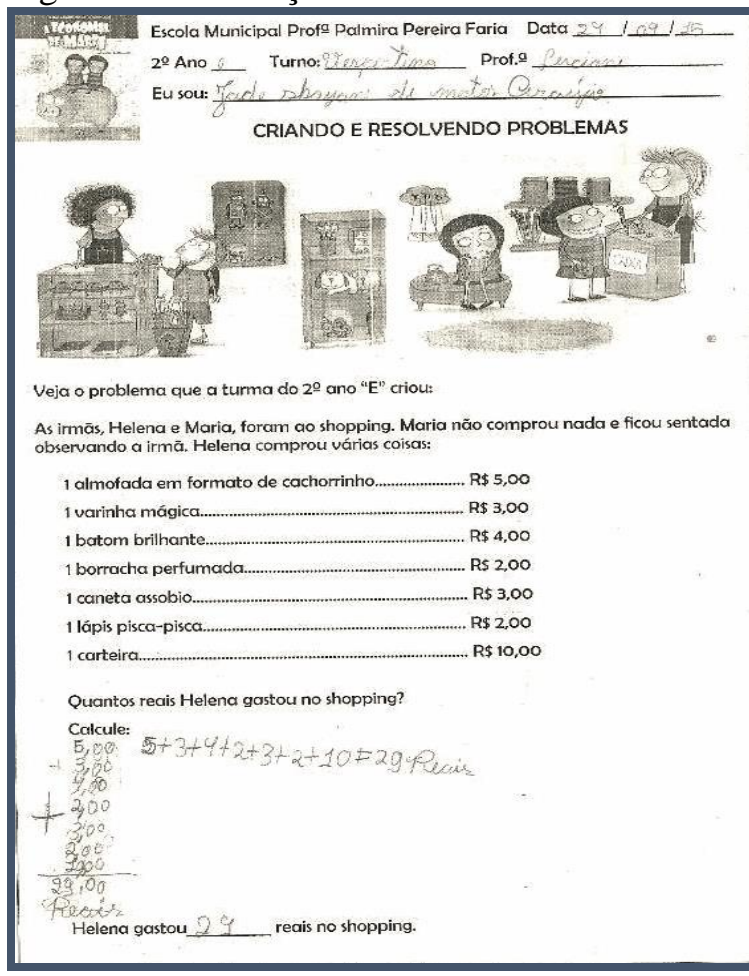

Jad (7 anos): Usa a conta na horizontal e a conta na vertical colocando as vírgulas embaixo de vírgulas como orientou a professora

Fonte: Arquivo da pesquisadora, 2015. 
O uso de bolinhas é visto no registro de três crianças: Henri, Ail e Tici

Figura 25 - Produções de Henri, Ail e Tici

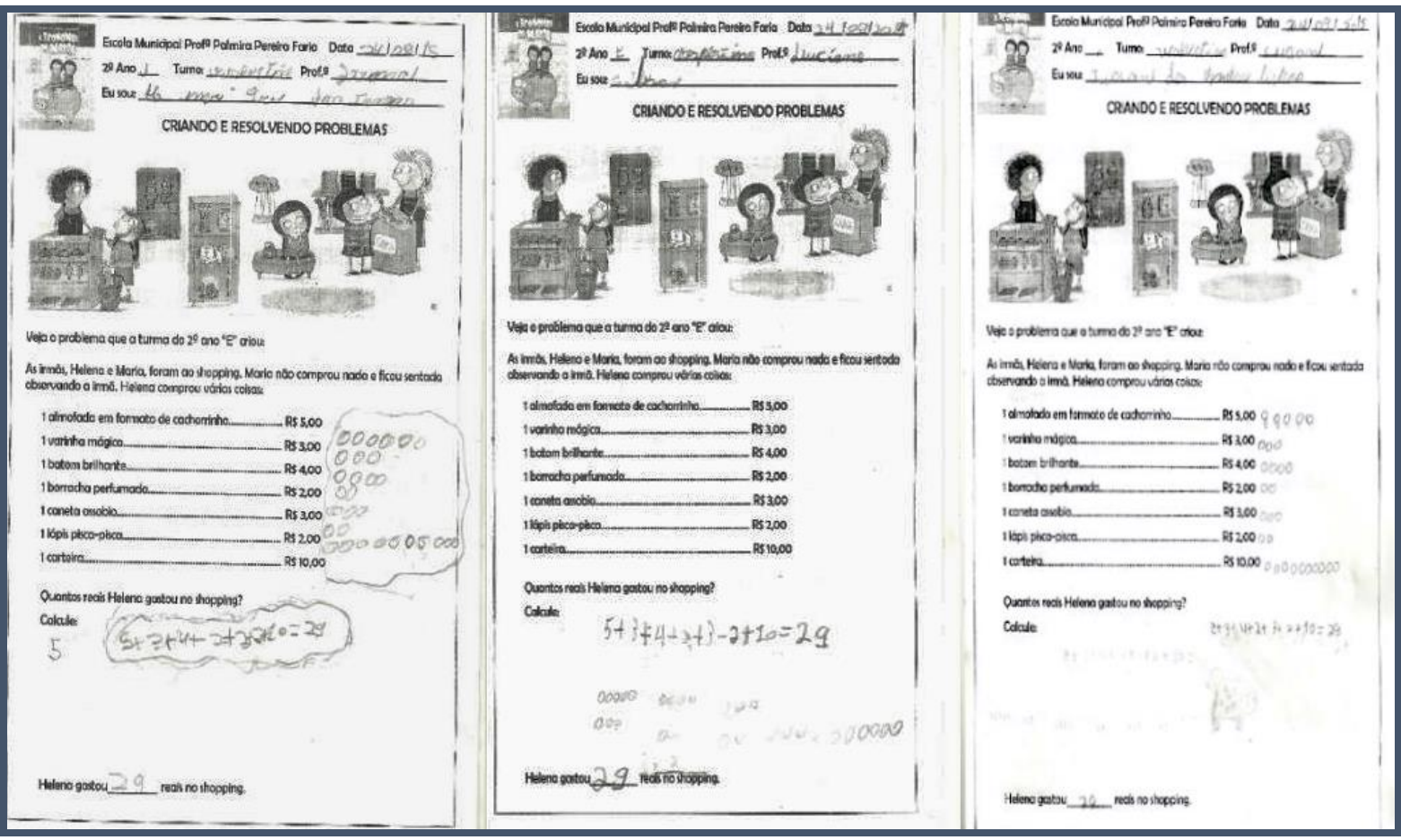

Fonte: Arquivo da pesquisadora, 2015.

Outros usaram os pauzinhos riscados no papel e os arcos sobre as parcelas que agruparam para operar:

Figura 26 - Registro com arcos e bolinhas

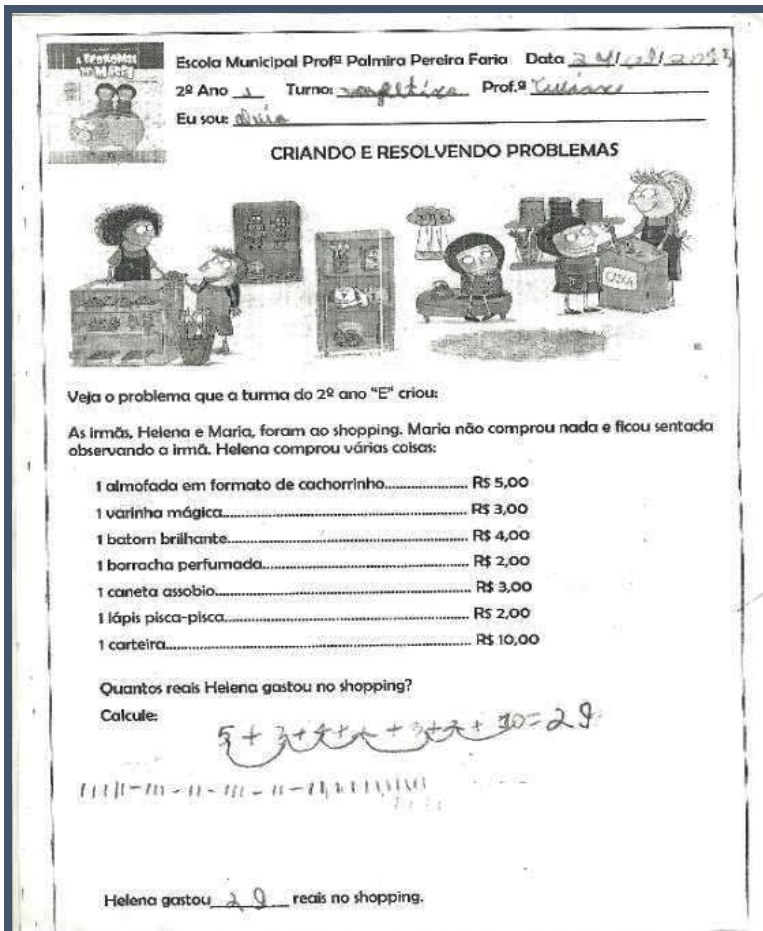

Max Almeida - arcos, bolinhas, números com as vírgulas e o registro da conta na horizontal 
Figura 27 - Registro com pauzinhos e arcos

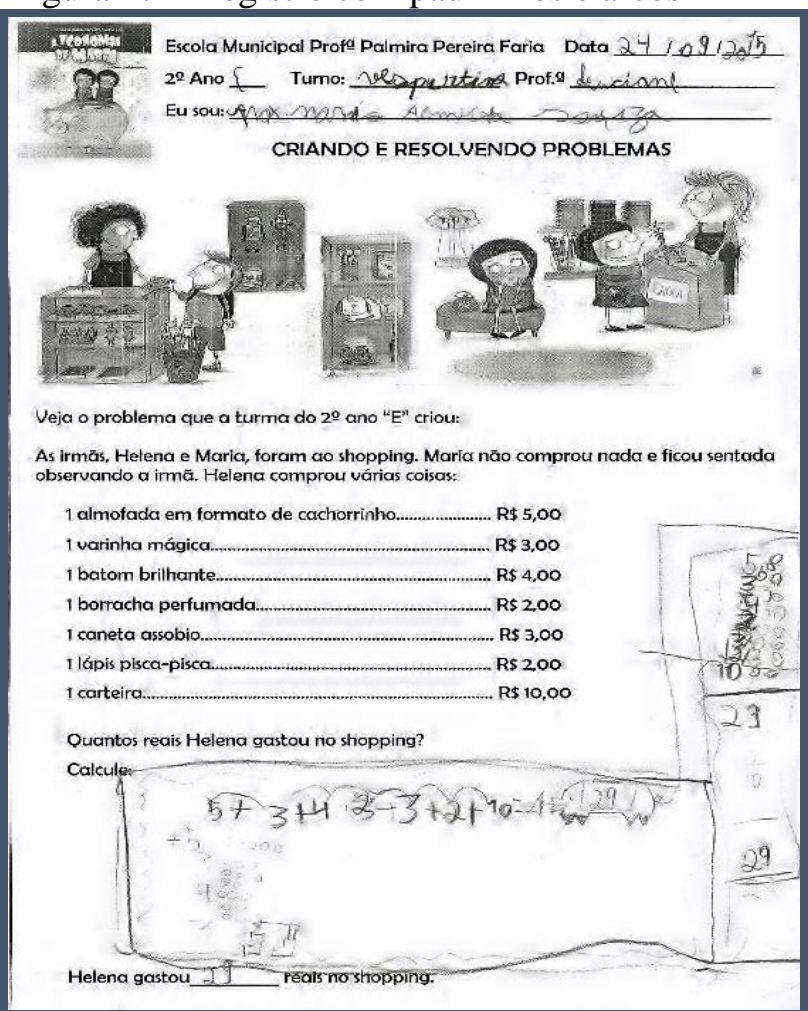

Alécio - pauzinhos e os arcos.

Fonte: Arquivo da pesquisadora, 2015.

O registro do David chama a atenção por ter desenhado o porquinho que é o cofre em que são guardadas as economias. A conta escrita na horizontal foi registrada dentro do cofre - o porquinho.

Figura 28 - Contas dentro do cofre

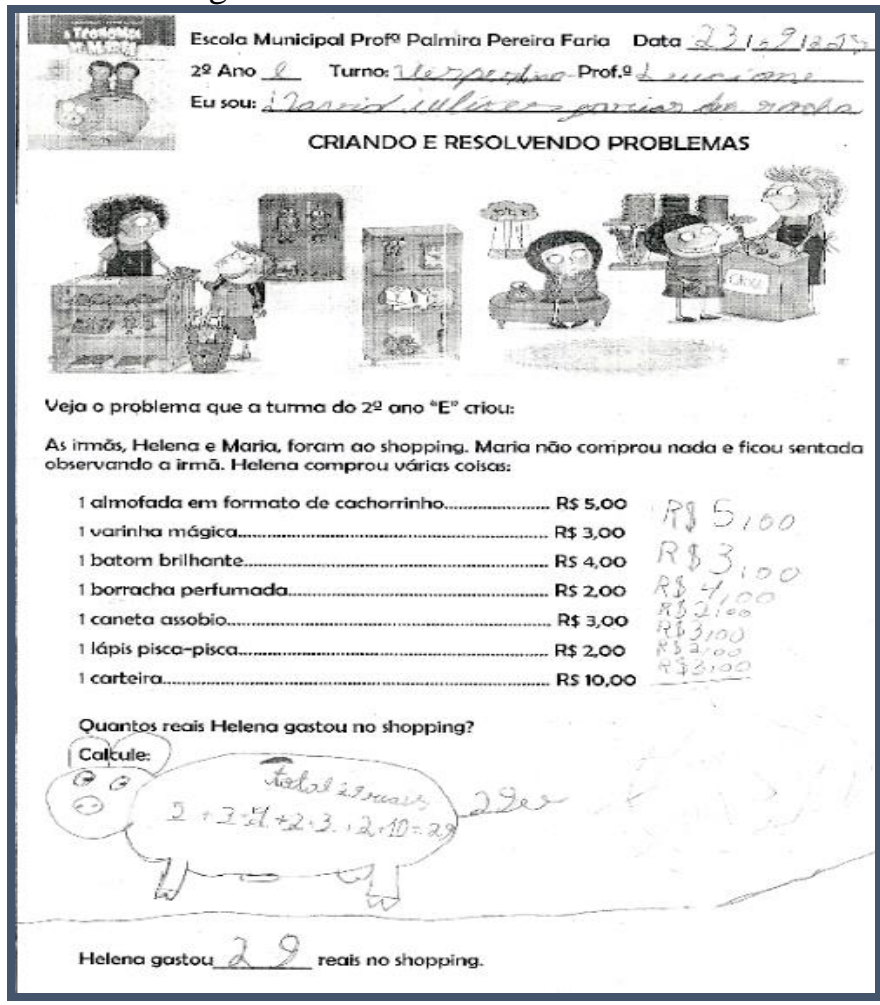

Fonte: Arquivo da pesquisadora 
Observamos que a aceitação do desafio de fazer um trabalho diferente, proporcionou às professoras realizarem um trabalho mais adequado ao tempo de aprendizagem da criança e ainda as colocaram na posição de autoras de uma atividade. Isso foi entendido por nós como evidência de uma crescente autonomia intelectual, provocada pela ampliação do conceito de alfabetização e de alfabetização matemática. Nos indagamos se o livro didático permite o mesmo espaço ofertado por estas atividades para a produção de registros, ao longo da interpretação e produção de procedimento resolutivo. Assim, pensamos que isso se relaciona à forma como o livro didático é utilizado, que tem estreita ligação com a forma de conceber a aprendizagem e o ensino, pois é possível explorar situações-problemas propostas no livro didático e prever no plano de trabalho espaço e tempo para a produção de registros pela criança.

Nas turmas do $3^{\circ}$ ano, o trabalho com o livro A Branca de Neve e os Sete Anões gerou situações bem interessantes, como pode ser visto na figura 29:

Figura 29 - Recorte do plano de trabalho do $3^{\circ}$ ano

\section{$4^{0}$ momento: Matemática}

Problematizar situações da história de Branca de Neve para os alunos resolvê-los usando a plataforma e material dourado.

Exemplo: Branca de Neve cuidava da casa, enquanto os sete anões trabalhavam na mina de ouro.

Ela preparava as refeições. Em um dia ela fez 55 pães e 34 bolos de pote. Ao final do dia os sete anões chegaram com muita fome, e cada um deles comeu 5 pães e 3 bolos.

a) Quantos pães sobraram para o café da manhã?

b) Quantos bolos sobraram para o café da manhã?

Obs. Possíveis perguntas para resolver os probleminhas.

Eram quantos anões?

Quantos pães Branca de Neve fez?

Quantos pães cada anão comeu?

> Como vamos fazer para saber quantos pães eles comeram ao todo?

$>$ Como faremos para saber quantos sobraram para o café da manhã?

$>$ Quantos bolos Branca de Neve fez?

$>$ Quantos bolos cada anão comeu?

$>$ Como vamos fazer para saber quantos bolos eles comeram ao todo?

$>$ Como faremos para saber quantos sobraram para o café da manhã?

Fonte: Arquivo da pesquisadora, 2015.

Uma das atividades criadas por uma das coordenadoras para explorar as operações e proposta para as turmas do $3^{\circ}$ ano foi a situação criada com o contexto da Branca de neve e os sete anões e a mina de diamantes, como mostram as figuras a seguir. 
Figura 30 - Situações-problema com o contexto de Branca de Neve

1- Com quantas pepitas de diamantes Branca de Neve ficou?

2- Se uma pepita de diamante custa $R \$ 12$ reais, quanto ela ganharia com a venda de todos os seus diamantes?

3- Quanto será que pesa esta quantidade de diamantes?

Obs. Pegar dinheirinho para representar a quantidade que eles falarem.

Para casa atividade de matemática na folha.

Fonte: Arquivo da pesquisadora, 2015.

Destacamos alguns registros interessantes que revelam como as propostas de ensino oportunizavam aprendizagens diferenciadas para as crianças.

Figura 31 - Registro de produção das crianças

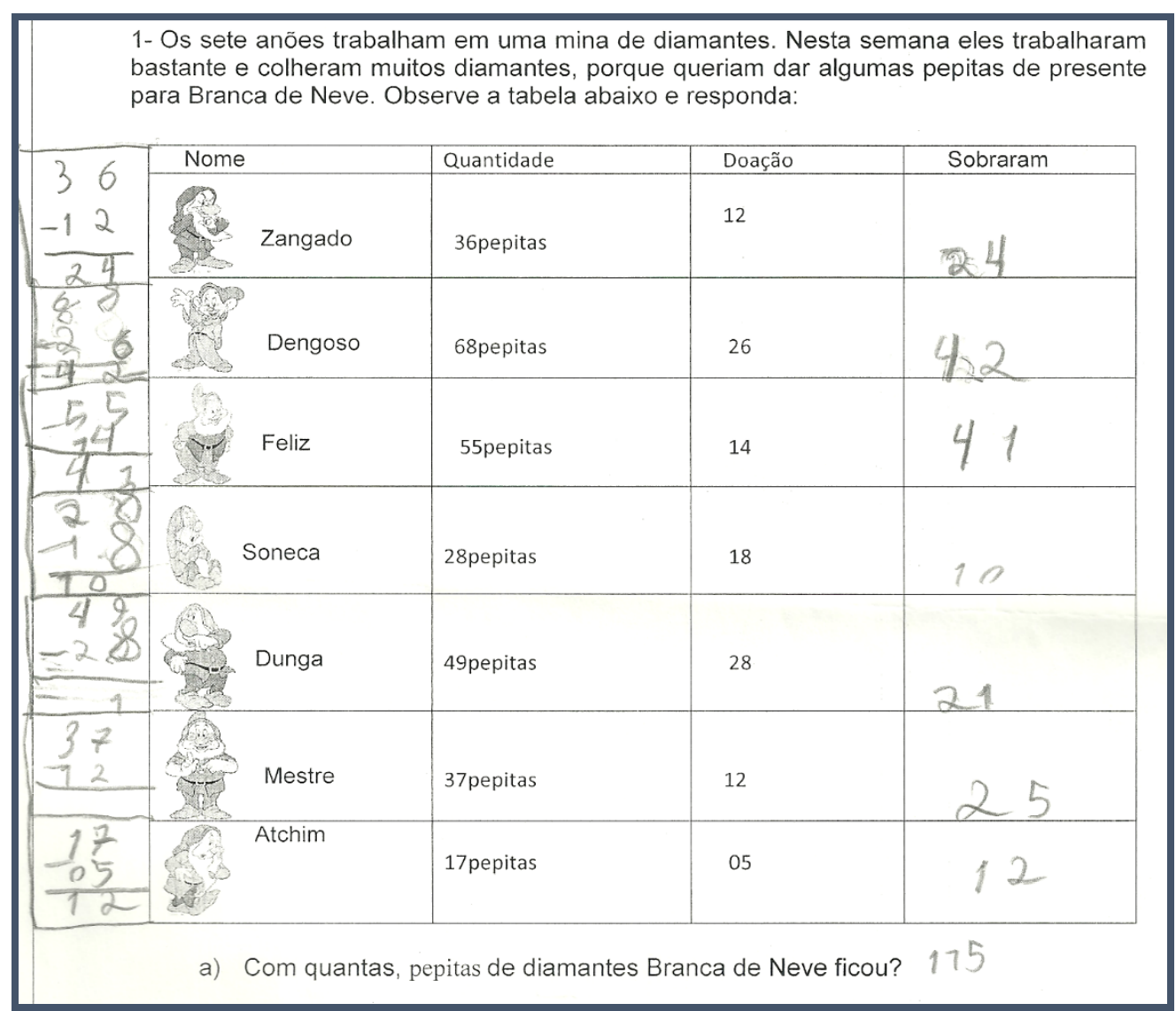

Fonte: Arquivo da pesquisadora, 2015. 
Figura 32 - Registro de atividade de uma criança

1- Branca de Neve cuidava da casa, enquanto os sete anões trabalhavam na mina de ouro. Ela preparava as refeições. Em um dia ela fez 65 pães e 36 bolos de pote.

Ao final do dia os sete anões chegaram com muita fome, e cada um deles comeu 8 pães e 5

bolos. $8+8+8+8+8+8+8=56$ Saloaram 9 país

c) Quantos pães sobraram para o café da manhã? 9

d) Quantos bolos sobraram para o café da manhä?

$5+5+5+5+5+5+5=07$

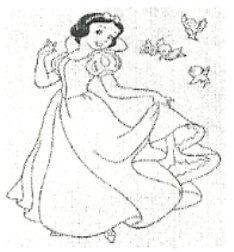

2- Branca de neve colheu na floresta 90 maças, cada dia da semana ela usou 7 maças para fazer suco. Quantas maças sobram?

c) Quantas maças ela usou para fazer suco? 17

d) Quantas maças sobram?

Fonte: Arquivo da pesquisadora, 2015.

Figura 33 - Exemplo de produção das crianças

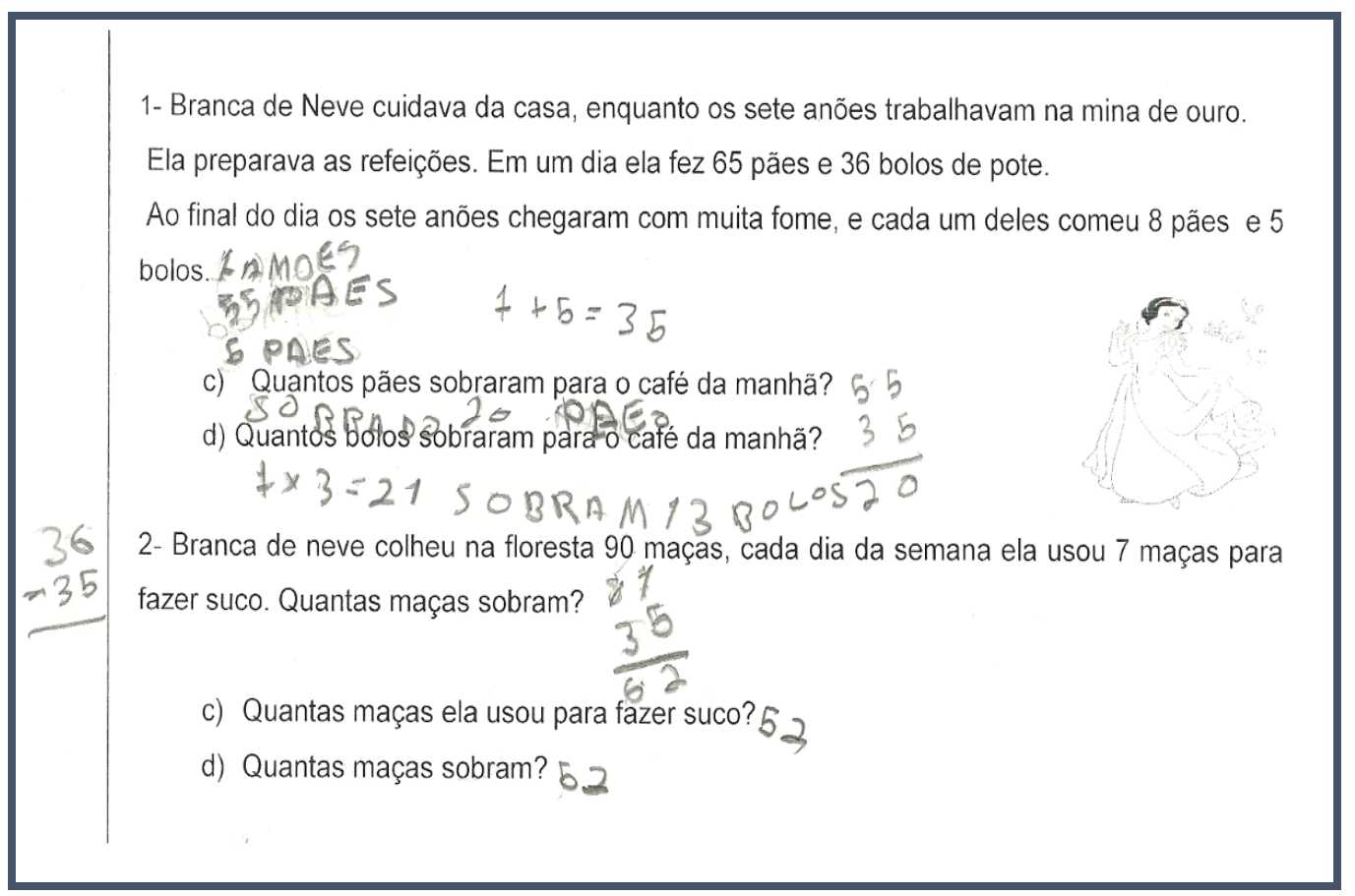

Fonte: Arquivo da pesquisadora, 2015.

Ainda podemos citar mais uma aula em que o livro paradidático foi explorado com muitas situações problemas contextualizadas. O enredo do livro Matar sapo dá azar (figura 34) mostra a história de um casal que saiu da cidade e foi morar no campo. A dona da casa não gostava dos sapos e ordenou ao caseiro que matasse todos eles. Isso rompeu com a cadeia alimentar e a casa passou a 
ser invadida por vários animais: insetos, cobras etc. Enfim, o casal teve de vender a casa e voltar para a cidade. Com o contexto da história, foram produzidos anúncios de venda da fazenda em que apareciam números com diferentes funções: a distância da fazenda à cidade, sua extensão, o valor total do terreno. Entre outras situações, foi pensada a venda das ferramentas. Nas figuras 35 e 36 pode-se ver algumas produções das crianças que ilustram as aprendizagens promovidas pelo envolvimento em situações-problemas que mobilizaram os conceitos de adição e multiplicação.

Figura 34 - Livro paradidático explorado pelas alfabetizadoras

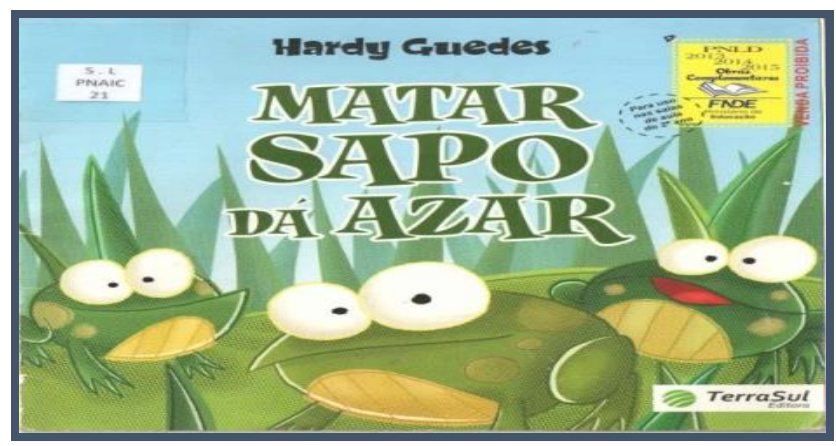

Fonte: Arquivo da pesquisadora, 2015.

Figura 35 - Registro das operações de adição

$\mathrm{Na}$ fazenda havia os instrumentos para o Sr. Dito cuidar das plantas e dos animais. Eles irão vender também esses instrumentos: enxada, pá, vassoura, latas, facão. Vamos calcular quanto eles conseguirão com essa venda:

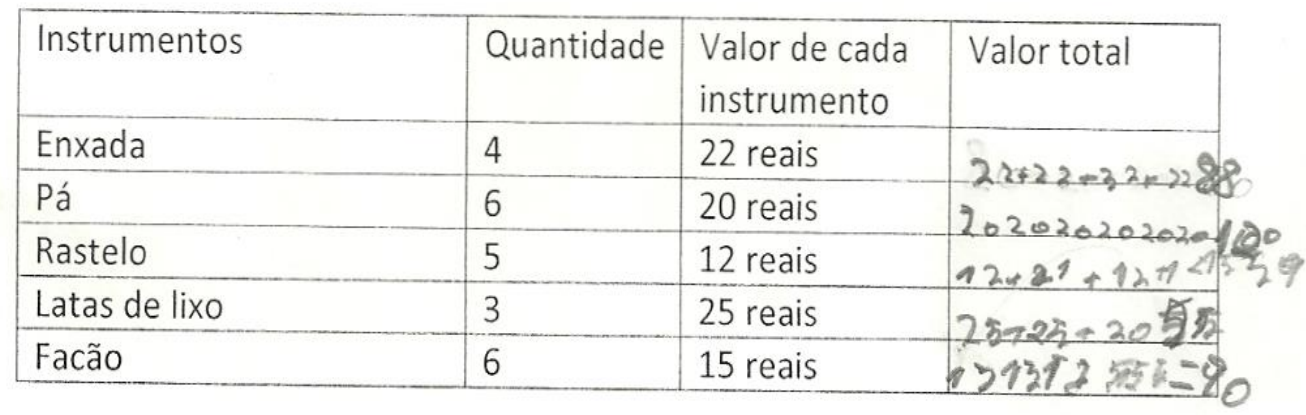

Quanto eles ganharam com a venda desses instrumentos.

Fonte: Arquivo da pesquisadora, 2015. 
Figura 36 - Registro das operações de multiplicação

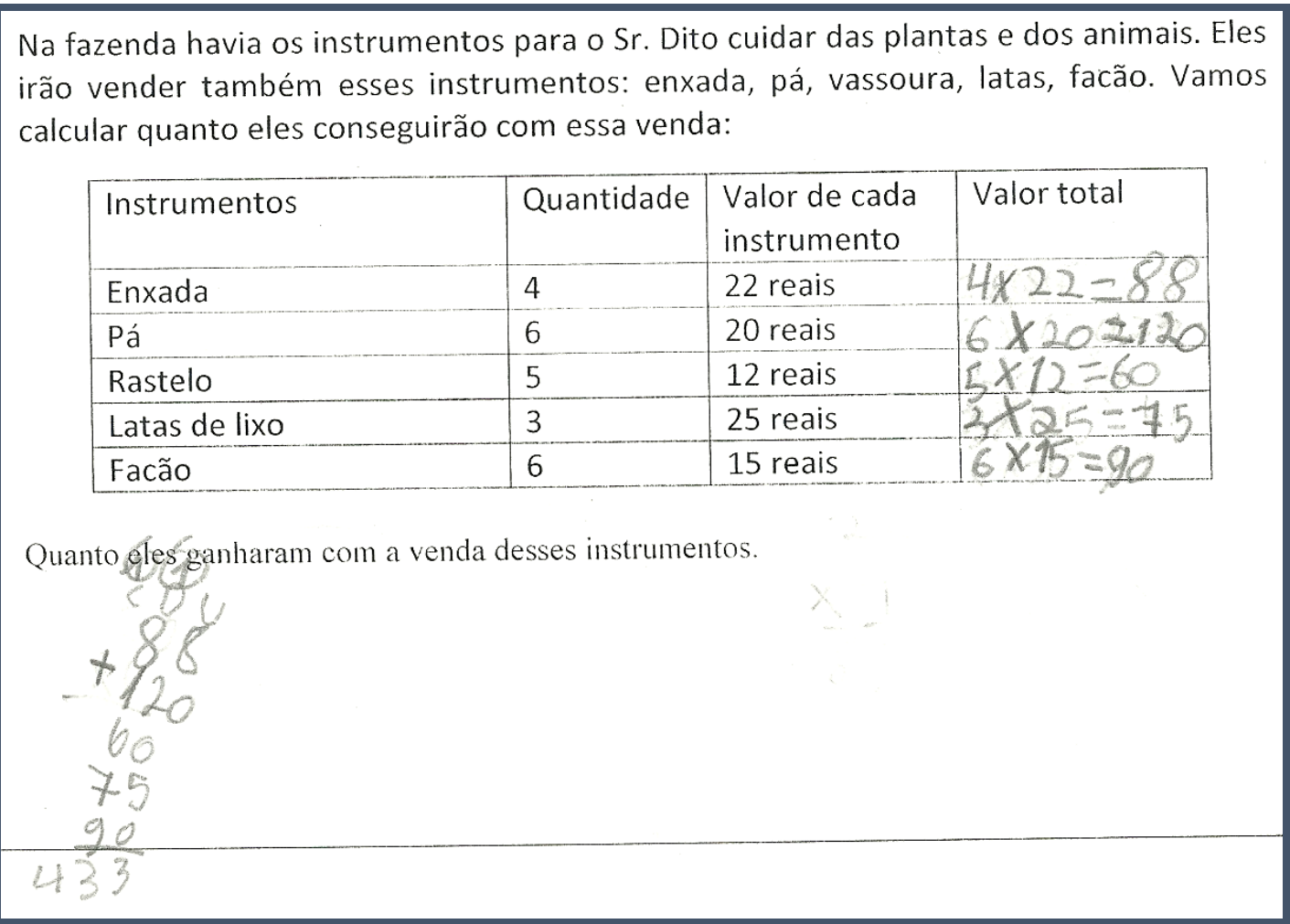

Fonte: Arquivo da pesquisadora, 2015.

Nas produções, é possível ver nos registros escritos o uso da linguagem matemática. Especificamente na figura 35 a criança usa a adição de parcelas iguais e na figura 36 outra criança usa a multiplicação. Isso é ilustrativo de que numa mesma classe, ao mesmo tempo, as crianças estão em relações diferentes com a linguagem matemática. Reforça-se assim, a ideia, de processo, de diferenças entre a compreensão e a forma de expressar essa compreensão. Abrir-se a atividades diversificadas, a um conjunto de situações para explorar os conceitos que se deseja ensinar amplia as possibilidades de aprendizagem.

Para finalizar essa seção, observamos que a exploração do contexto das histórias infantis auxiliou na aprendizagem das alfabetizadoras e das crianças à medida que a compreensão do processo de alfabetização matemática foi ampliada. Inferimos que na dinâmica de trazer os textos já familiares da área de português e explorá-los na área de matemática, foram constituídos conhecimentos que serviram de elementos de desenvolvimento profissional e consequentemente apoiaram a construção de uma práxis diferente, o que nos indicaram caminhos para o alcance de nossos objetivos de pesquisa. Na constituição desta categoria, ao buscarmos as informações referentes aos eixos Estatística, Grandezas e Medidas e Geometria, percebemos que algumas atividades referentes a esses eixos foram inseridas nos planos de trabalho, mas de fato a discussão sobre a organização do trabalho pedagógico para a exploração dos conteúdos que integram esses 
eixos não ocorreu do modo como desejávamos. Esse aspecto foi mais uma evidencia da prioridade que é dada pelas alfabetizadoras ao eixo números e operações, confirmando o que foi sinalizado por Nacarato (2013), ainda há forte tradição, no ensino de matemática dos anos iniciais, de dar maior importância ao campo da numeração.

Em um dos encontros colocamos alguns pontos em discussão:

(1) Em relação a grandezas e medidas: - As atividades propostas oportunizavam a percepção da grandeza? Foram vivenciadas experiências de medição? Foram identificados e experimentados os instrumentos de medida? A criança é capaz de identificar mais que 1quilograma ou 1 quilograma ou menos que 1 quilograma? Mais que 1 metro ou 1 metro ou menos que 1 metro? Mais que 1 litro ou 1 litro ou menos que 1 litro?

(2) Em relação ao eixo de estatística: As situações oportunizavam a coleta e a organização de dados? Nessas situações, as crianças formularam questões, elaboraram hipóteses, escolheram amostra e instrumentos adequados? Os gráficos e tabelas foram utilizados como recursos para gerar situações problemas que envolviam os outros eixos de aprendizagem? E os pensamentos combinatório e probabilístico foram contemplados nas atividades propostas?

Decorrente dessa problematização, indicamos material de leitura, mas não avançamos nas discussões e nem na elaboração de planos de trabalho.

Em relação a geometria a situação não se mostrou diferente de outros resultados de pesquisa. Podemos citar Mandarino (2009) que identificou a seleção e distribuição dos conteúdos de matemática escolar trabalhados por um grupo de 116 professores dos anos iniciais, constatou que são priorizados o campo de números e operações. Atentamos para suas afirmações sobre o fato de que este tema:

ensino de geometria na educação básica - ter sido objeto de muitos estudos e pesquisas no final do século XX, mesmo assim os resultados destes trabalhos ainda não foram incorporados à prática dos professores. Podemos citar a tese de Pavanelo uma das pioneiras neste tema. Esse fato é mais grave no ensino fundamental I, especificamente no Ciclo de Alfabetização, pois neste segmento enfatiza-se a língua materna. Acrescentamos que, além disso, temos o agravante da falta de domínio conceitual por um grande número de professoras, em consequência do longo período de abandono ao ensino da geometria. $\mathrm{Na}$ trajetória escolar do ensino fundamental e médio e na graduação as professoras não estudaram geometria. (MANDARINO, 2009, p. 29)

Isso foi atestado pelas alfabetizadoras participantes dessa pesquisa que, com muito boa vontade, contaram sobre sua desilusão com a geometria e registraram isso por escrito. Colocamos para elas três perguntas: (1) O que aprendi de Geometria na formação inicial? (2) O que ensino do conteúdo de Geometria no Ciclo de alfabetização? (3) O que espero aprender sobre Geometria em um possível espaço de estudo constituído na escola? E, naquele momento, dois professores- 
formadores do curso de licenciatura em matemática, interessados em estudar esse tema, fizeram, junto com a pesquisadora, a análise das respostas, o que resultou em um texto intitulado "Geometria nos anos iniciais: ainda uma questão a investigar?" (PEREIRA; NASCIMENTO; SILVA, 2015) ${ }^{29}$.

Os depoimentos nos deram algumas indicações de como organizar possíveis encontros de formação, mas não houve consenso sobre qual tempo iríamos disponibizar para essa formação específica. Os conceitos geométricos são classificados pelas alfabetizadoras como de alto nível de dificuldade. Essa dificuldade não se refere em primeiro plano à dificuldade de construção conceitual das crianças, mas as suas próprias dificuldades, que estão associadas tanto a sua vida escolar quanto a ausência de uma formação em geometria no curso de formação inicial. Elas revelaram o desejo de estudar desde o início, sem pressa e com tempo para que aprendessem. Algumas afirmavam que no ano anterior trabalharam com os conceitos geométricos, no entanto: "houve uma previsão no plano de trabalho, mas a forma como foi ensinada, foi sem significado para nós professoras e, com certeza, incompreensível para a criança".

Em nossas conversas com as alfabetizadoras, observamos que a "não aprendizagem" da geometria implicava em não inserir os conceitos geométricos nos planos de trabalho e, consequentemente, em não oportunizar às crianças a aprendizagem desses conceitos. Dessa forma, não é que haja uma "não aprendizagem" por parte das crianças, o que ocorre é uma ausência de ensino, pois as alfabetizadoras, por insegurança, se furtavam de tratar pedagogicamente esse tema. Mesmo que a visão da matemática não fosse tão positiva e a relação com essa área de conhecimento fosse conflituosa, ao tratar com os conceitos geométricos, isso se agravava muito mais.

O nosso tempo coletivo continuava a ser o horário de coordenação às sextas-feiras (nossos 90 minutos). O estudo da geometria ficou em último plano. Isso foi refletido nos planos de ensino e nos encontros de discussão. Esse foi um problema e uma dificuldade que a pesquisa não conseguiu superar em 2015. Em 2016, iniciamos nossos encontros de formação com o estudo de conceitos geométricos.

Desse modo, foi possível notar que havia uma preocupação em propor uma atividade que exigiria a apropriação do conceito, mas nem sempre essa atividade possibilitava a constituição progressiva e processual do conceito exigido. Por exemplo, algumas atividades não previam experiências de medição que contribuíssem para a percepção da grandeza (Eixo Grandezas e Medidas) e tampouco atividades de investigação, coleta e organização de dados (Eixo Estatística) ou exploração do espaço físico (Eixo Geometria).

\footnotetext{
${ }^{29}$ Texto apresentado em Encontro de Educação Matemática nos Anos Iniciais,UFSCar, 2015
} 
Uma questão permanecia: havia uma ausência do conceito de alfabetização ou um equívoco nesse conceito? Por mais interessante, lúdica ou contextualizada que pudesse ser ou parecer a atividade, se ela estivesse ancorada em uma ideia equivocada de alfabetização, não seria dado o tempo suficiente para a constituição do conceito pela criança que, insistimos, encontrava-se em processo de alfabetização.

De qualquer forma, após o trabalho em 2015, as alfabetizadoras explicitavam uma maior compreensão sobre o ritmo de aprendizagem da criança e, ao pensar no ensino e na aprendizagem, era preferível não acelerar e nem prever a exploração de muitos conteúdos que iriam apenas atropelar a criança e prejudicar a sua apropriação e produção de conhecimento. Esse seria um grande desafio para o próximo ano (2016), distribuir os conteúdos dos diferentes eixos de modo a contemplar todos durante o ano e ficou em pauta a ampliação da carga horária de matemática. 


\section{CAPÍTULO 4}

\section{A RELAÇÃO ENTRE A FORMAÇÃO CONTINUADA EM SERVIÇO NA ESCOLA E AS MUDANÇAS NA PRÁTICA EM ALFABETIZAÇÃO MATEMÁTICA}

No registro das falas das professoras, na discussão dos textos lidos, na escrita dos planos de aula, nos textos produzidos que versaram sobre sua prática ou sobre a aprendizagem de seus alunos, selecionamos as informações referentes às aprendizagens reveladas, ao abandono de velhas crenças, à adoção de novas concepções, ao diálogo teoria - prática, à ampliação do entendimento do significado da alfabetização. As novas aprendizagens passaram a orientar a construção de tarefas e a seleção de recursos didáticos, o que consideramos como produção de conhecimentos pedagógicos. Isso foi associado à criação de uma autonomia intelectual, na medida em que as professoras entenderam o que significa tomar a prática como objeto de análise e, nessa dinâmica, emergiu o conceito de formação continuada em serviço na escola.

Nossa ação de pesquisa e formação, nesse aspecto, apoiou-se nos estudos apresentados no primeiro capítulo. Esses referenciais foram, nessa seção, a base para analisar e descrever o processo de formação continuada em serviço, que se constituiu na escola em um percurso da prática à práxis. Extraímos as informações das cenas descritas em diário de campo, gravadas em áudio e vídeo, dos momentos em que as professoras alfabetizadoras sentiram-se desafiadas a deixar de lado uma prática irrefletida e a constituir uma nova postura.

Reafirmamos nossa compreensão sobre formação continuada como algo dinâmico, que acontece o tempo todo, acompanha e integra o desenvolvimento profissional do professor. Desse modo, entendemos que ela não é pontual e não se reduz ao que alguns, equivocadamente, pensam ao defini-la como a realização de cursos diversos e descontínuos. Ela não ocorre apenas na leitura de uns poucos textos. Compreendemos que a formação continuada se constitui numa reflexão/problematização permanente, em busca de solucionar problemas que afloram a todo o momento, em sala de aula, na complexidade de ensinar, principalmente ensinar matemática. Isso está relacionado ao desenvolvimento da capacidade de estudar, de planejar e de gerir o processo didático ao assumir-se como agente social. A reflexão/problematização que dá suporte a essa formação não é individual e sim coletiva, no espaço da escola, com envolvimento dos integrantes do grupo de professores, com a complexidade das tensões e conflitos implicados nessa formação, que é essencialmente coletiva. 
Nesse processo de classificação, as informações nessa categoria foram agrupadas em três subcategorias, como mostrou o quadro 03, que são analisadas a seguir: (1) As aprendizagens, o abandono de velhas crenças e a adoção de novas concepções; (2) O diálogo teoria - prática, a produção de conhecimentos, a ampliação do conceito de alfabetização matemática e a reorganização do trabalho pedagógico; (3) A construção da autonomia intelectual: da prática à práxis. É importante explicitar a dificuldade de definir um caminho coerente para análise, principalmente quando as informações mantêm entre si uma interconexão muito forte e uma mesma informação pode ser evidência de muitos aspectos referentes ao que está em estudo.

\subsection{AS APRENDIZAGENS, O ABANDONO DE VELHAS CRENÇAS E A ADOÇÃO DE NOVAS CONCEPÇÕES}

Nesta subcategoria, vamos analisar as informações construídas em alguns dos encontros de estudo, na discussão, na problematização e na reflexão da prática, gravadas em áudio e vídeo. É possível que, em um mesmo trecho, de algum depoimento, se encontrem indícios do que as professoras pensavam sobre: a criança, a matemática, a aula de matemática.

Vimos a professora Dan referir-se a um conteúdo que não era ensinado quando ela estudou: gráficos e tabelas. E, mesmo assim, ela estava trabalhando com eles, como se pode verificar no trecho em que ela afirma: "Quando estudei... Nem sabia o que era um gráfico... nem sabia o que era uma tabela [...]". Em seguida ela expressa o que pensava sobre a matemática e, consequentemente, o seu sentimento em relação a aula de matemática: "Antes ficávamos presas não via a hora do tempo acabar para terminar essa aula por obrigação. Ah eu tenho que dar essa aula?! Nossa! Nem sabia por onde começar [...].

A matemática escolar era considerada um conhecimento "chato" e sem sentido. Essa concepção sobre a matemática tornava a aula dessa disciplina uma obrigação a ser cumprida, pois fazia parte do currículo. Mesmo sem ter construído uma boa relação com essa área do saber (CHARLOT, 2005), a professora se obrigava a ensiná-la.

Observamos que em algumas falas elas demonstraram "surpresa" com o potencial de aprendizagem das crianças: “ fiquei impressionada com a rapidez de raciocínio deles"; "você se surpreende na sala de aula é com o que os meninos sabem"; "tenho que registrar isso a gente percebe como eles se envolvem"; "eles se sentem parte eles compreenderam"; "nos surpreendem"; “como Lu falou eles trazem informações, tem opiniões, eles têm ações que a gente nossa, a gente nunca imaginou que poderia acontecer em sala. Nossa!!! A gente nem 
pensava"; "são pensamentos que eles conseguem atingir que você nem imaginava"; "nossa eles têm uma capacidade incrível"; "como eles descobriram isso?".

Inferimos, a partir dessas falas, que havia uma crença de que não poderíamos perguntar à criança algo considerado difícil, como os conceitos matemáticos e muito menos incitar a discussão durante a aula, pois parecia incompatível associar a criança pequena com a matemática complexa. Decorre desse fato a necessidade de "tomar a aula para si", a fim de minimizar talvez o "sofrimento da criança" em ter de confrontar-se com um conhecimento tão distante de seu potencial. Isso nos remete aos resultados de Muniz (2006) que revelam o potencial das crianças que, muitas vezes, é desconhecido pelas professoras.

Destacamos também as evidências que indicam que, caso a professora não estivesse envolvida e apoiada pela dinâmica de pesquisa e sustentada na ação coletiva (NACARATO, 2013), algumas práticas não teriam sido permitidas devido às concepções de que a movimentação, os questionamentos e as falas simultâneas das crianças poderiam ser vistas como bagunça e não como momentos de mobilização de conhecimentos, como nesse trecho da fala da profa. Sam.: "Se eu fosse fazer uma contagem dessa. Eu particularmente. Eu... começou a contar eu mandaria parar tudo... Parou não conta mais nada... até a gente se estressava e parava e não aproveitava esse momento... E estamos todas fazendo". Outra evidência da importância do apoio mútuo está na fala da coordenadora que entrou em sala a pedido da professora, para auxiliá-la na orientação dos pequenos grupos: "Eu fui na sala de Fran porque ela me pediu ajuda...".

Nacarato (2013) nos ajudou na compreensão do que estava acontecendo quando, juntas, as professoras, pesquisadora e coordenadoras pensavam em uma atividade e, mesmo com alguma insegurança, as professoras desenvolviam essa atividade em sala de aula. A ação da pesquisadora e das coordenadoras de entrar em sala de aula e apoiar ao invés de fiscalizar, contribuir e ajudar com a orientação dos grupos e com a distribuição do material foi fundamental para que as professoras sentissem que aquela proposta de trabalho poderia vir a ser promotora de aprendizagens. Importante lembrar que nem todas faziam as atividades ao mesmo tempo, mesmo que estivessem previstas em um plano no mesmo dia e no mesmo horário, vários eram os fatores que faziam cada professora desenvolver em sua turma em seu tempo, inclusive em respeito ao seu entendimento.

Outra ideia que destacamos nas falas foi a de que os conteúdos devem ser compartimentados, trabalhados um de cada vez. Essa forma de ver o currículo já foi bastante debatida (PIRES, 2000) e poderia ter sido superada, mas ela ainda está impregnada na prática das professoras que, mesmo ao serem polivalentes, separam os conteúdos em “caixas", não visualizam uma organização curricular em rede e ainda adotam uma forma linear de proposição dos conteúdos 
matemáticos. Elas sentem dificuldades em identificar as conexões dentro da própria área e ainda mais em perceber as possíveis conexões entre a matemática e outras áreas de conhecimento. $\mathrm{Na}$ sequência da fala, revela-se essa ideia e, felizmente, elas expressam indícios de que com a continuidade do trabalho ela seria superada, pois uma nova aprendizagem começava a acontecer, como podemos ver nesses trechos da fala da professora Lu: "quando a gente ia planejar não conseguia visualizar muita coisa [...] o foco era só adição com sinais algum probleminha e hoje temos uma visão mais ampla... envolve as ciências, os animais, envolve português em matemática. [...] é alfabetização... a maneira como fala os números e como escreve [...] todo conteúdo dentro de outros conteúdos [...] então trabalha matemática e alfabetização".

Ao longo do ano de 2015, conseguimos ver as possibilidades de conexão entre os conteúdos de matemática, mas isso ocorreu com os conteúdos mais familiares, que integram o eixo de aprendizagem matemática números e operações. De novo o conhecimento do conteúdo (SHULMAN, 1986) e a relação com o saber (CHARLOT, 2005) emergiram de forma recorrente. A possibilidade de conexão com as outras áreas foi também comentada pelo grupo, mas não aprofundada e, assim, a construção de propostas interdisciplinares foi limitada à relação entre a leitura, a escrita e a matemática. Por exemplo, explorar as conexões entre a matemática e as artes, nos mosaicos construídos com figuras planas; a matemática e os tempos históricos, na construção da linha de tempo; a matemática e a geografia, na possível alfabetização cartográfica, com os conceitos de orientação e deslocamento em geometria; todos esses tópicos ainda ficariam para outro momento e entendemos que isso é processo e demanda tempo, ampliação de conhecimentos e uma nova visão de currículo.

Vimos ainda que o que é vivenciado no nosso processo de escolarização, anterior ao curso de formação inicial, fica mais forte em nossa prática do que as aprendizagens que possam ter ocorrido durante aquele curso, mas que não se tornaram "hábito", pois podem ter se limitado a leituras e discussões e não foram vivenciadas a ponto de serem traduzidas em uma prática e, de fato, tornarem-se um hábito, como expressou uma das participantes da pesquisa: "Prof. Sam: A palavra que acho que é para nós é hábito. [...] não tínhamos o hábito de pensar em cima do que fizemos".

Para melhor compreendermos esse aspecto colocado pela professora Sam, buscamos o conceito de hábito e encontramos em Bordieu (1996) uma interessante discussão que coloca o termo habitus como referente a princípios geradores de práticas distintas e distintivas; ele seria algo que se apresenta como social e individual, que está relacionado a um grupo, a uma classe ou a um indivíduo e aparece como um conceito fundamental para explicitar uma possível articulação entre as condições de existência do indivíduo e suas formas de ação e percepção. Decorre disso o fato de 
ser viável relacionar práticas cotidianas com as condições de classe de determinado grupo social em que se unem as condições objetivas e subjetivas.

Ao transpor esse conceito para o nosso grupo identificado como - professoras alfabetizadoras em processo de trabalho na escola dos anos iniciais — podemos inferir que havia um habitus primário (BORDIEU,1996) de fazer o trabalho de uma certa forma. No entanto, ainda segundo esse sociólogo, na convivência com outras pessoas, com outras formas de ver, com outras práticas, são desenvolvidos habitus secundários indissociáveis dos anteriores, mas diferenciados daqueles e esse movimento ocorre continuamente à medida que novas experiências forem agregadas às suas práticas. Neste sentido indagamos em que contexto e situações e de que forma as professoras constituíram alguns habitus? E como a formação continuada em serviço na escola pode vir a contribuir no desenvolvimento de outros habitus?

Em um dos encontros de formação, realizado em agosto de 2015, foram evidenciadas as aprendizagens que aconteciam entre as professoras e que influenciavam a adoção de uma nova postura. Identificamos o que elas mostravam que estavam aprendendo quando percebiam as evidências de aprendizagens das crianças, inclusive as mudanças no modo de olhar para o material concreto e de organizar o ambiente da sala de aula, com destaque ao trabalho em grupo.

Professora Jan: a questão do trabalho em grupo... Eu acho que minha turma já avançou bastante nessa questão de trabalhar em grupo. Estava sentindo muitas dificuldades de realizar o trabalho em grupo com eles, mas acho que melhorou bastante (repetiu).

... ainda tem claro dificuldades com alguns, mas percebo que outros estão me surpreendendo a cada dia... aqueles até que eu achava que tinham mais dificuldades.. eles estão se expressando... eles estão participando mais e melhor.... e dando opiniões, dando sugestões e eu percebendo que eles estão adquirindo conhecimentos realmente....

Lá no jogo forme 10 da semana passada.. que foi grupo contra grupo ... no início a melhor coisa foi definir as tarefas de cada um,

Pesquisadora: Ah aquela adaptação que fizemos.

Professora Jan: Essa! Foi maravilhosa porque o que estava responsável em jogar o dado, o que estava responsável em contar... Cada um estava atento a sua tarefa e se comportaram muito bem e depois eles quiseram trocar de tarefa eu deixei, mas cada um atento a sua tarefa e cumprira bem (frisou).

Professora Fran: Tem as picuinhas, mas o resultado...é tão bom que a gente esquece o lado ruim... temos de trabalhar sempre em grupo, principalmente na matemática, até mesmo para que eles se ajudem. Acho que eles tem que descobrir como resolve... Insisti com o material, não tinha como intervir como perguntar, agora estou mais familiarizada ... estou gostando... para falar verdade... não gostava... agora quero que chegue logo o segundo momento( no plano de trabalho após o intervalo era o tempo previsto para matemática) para gente não perder tempo... e trabalhar em grupo não é fácil....

Professora Lu: E a questão da pergunta é importante, por exemplo, quero saber quantos grupos de 10 (eram 4). Eles faziam confusão com a quantidade: quarenta, então eu repetia quantos grupos de 10 , observem que cada grupo de 10 é uma dezena, então são um grupo, dois grupos, três grupos( mostra o gesto que fez com as crianças). [...] Eles já conseguem fazer, dizer 4 grupos de 10 que dá $40 \ldots$ tem crianças que já estão além...tem crianças que dizem logo... tem crianças que não precisaram de ajuda.

Além disso, nos diálogos também destacamos as referências ao trabalho em grupo: 
Professora Lu: vamos manter esse trabalho em grupo, pois isso vai fortalecendo e aí eu também tem os critérios..olha a organização... olha a disciplina... eles ficaram ligados nisso eu achei muito bom... ainda não terminei o jogo individual... esse trabalho esse conhecimento de trocar eles já tem... Até mesmo os que tem dificuldade já avançaram... algumas crianças que dominam mais elas próprias direcionavam o trabalho em seu grupo... agora é fulano... agora é beltramo... na primeira rodada , na segunda .houve uma organização entre eles que favoreceu o desenvolvimento do jogo... lógico que algumas equipes precisaram de ajuda... é sua vez registra... acompanha

Pesquisadora: Lembra que falamos de ter um líder em cada grupo...

Professora Lu: Sim, mais eles se organizaram e um assumia como líder... mais de 10 e pegavam logo o 10 e depois as soltas...

Sabemos que em algumas escolas ainda não é comum permitir ou incentivar os alunos a trabalhar em grupo. Apesar de essa forma já ser defendida desde a edição dos PCNs (1997), ainda não se tornou comum. Algumas professoras ainda acreditam que fazer matemática NA ESCOLA é tarefa individual. Nacarato $(2009,2014)$, uma autora já bastante referida em nosso texto, por ser estudiosa da matemática nos anos iniciais, defende que seja criado na sala de aula um ambiente de aprendizagem. E uma das características desse ambiente é o diálogo entre a professora e as crianças e entre as próprias crianças.

Assim, a organização espacial da sala em grupos é que favorece a comunicação entre essas pessoas. Entretanto, sabemos que apenas colocar as crianças em grupos pode não fazer acontecer a comunicação, é preciso instigá-las. Parece algo trivial, mas é preciso conversar com as crianças, não uma conversa unilateral, em que já se tem as respostas prontas para perguntas inócuas, mas realmente envolver a criança em busca da compreensão da situação que está em processo de resolução.

Isso lembra-nos tanto Alro e Skovsmose (2010) e Nacarato (2014) com a proposição de comunidades de aprendizagem, quanto Brousseau (1996) quando destaca a importância de se promover situações em que aconteça a devolução. Quando a professora Fran afirma que está aprendendo a fazer perguntas, ela revela sua adesão ao diálogo que traz implícita a ideia de que a criança pensa, produz conhecimento e fala. Algo que aparentemente é óbvio para alguns professores, não é para outros que, ao pensar a aula, não pensam no tempo da criança dar respostas ao que será proposto; pensa-se sempre no tempo do professor, na ação do professor. Pensar no diálogo que será promovido durante a aula é algo essencial quando se quer mudar a aula de matemática.

É interessante registrar que mudar não é fácil. Em uma das falas revelou-se o medo de "perder o controle": 
Professora Lu: eu falo que tive mais dificuldade no jogo de cada grupo porque você perde o controle, e você quer ter o controle. Na equipe contra equipe eu tinha o controle. Equipe $1 . .$. todos registram... estava direcionando... tinha o controle da situação toda... facilita para o professor e quando parte para todos jogando ao mesmo tempo você já fica angustiada... pois perdi um pouco o controle...para estar observando todos os grupos... interessante que teve um grupo o Heure já fiz e eles fizeram a soma com o uso do algoritmo... Aí fiz com eles usando as tampinhas. Fomos conferindo realmente se o resultado...

Essa professora é também coordenadora e tem facilidade de se expressar e não esconde seus medos e suas concepções, é muito exigente com ela mesma e com as crianças. Desse modo, foi interessante mostrar ao grupo o seu medo de mudar a organização da aula, pois isso poderia resultar em "perder o controle". A necessidade de controle é própria de um modelo de formação de professores, vivenciado por nós, em que um dos itens para avaliar e caracterizar uma professora como boa profissional era sua capacidade de controlar a turma.

Observamos que a conta realizada pela criança com uso do algoritmo foi conferida pela professora com o material de contagem como uma forma de controlar a ação da criança - ele fez, vamos conferir. Esse medo foi superado, ao mesmo tempo em que as aprendizagens das crianças ficavam explícitas; o que felizmente era o maior objetivo da coordenadora/professora.

Discutimos, no primeiro capítulo, a relação entre o professor e o saber que, em alguns casos, é complicada. Pensar na matemática escolar como acessível, sentir-se capaz de aprendê-la, compreendê-la a ponto de criar formas de ensiná-la era algo necessário e que as discussões e os estudos oportunizavam. E nesse contexto continuava o desenvolvimento de um outro olhar para o uso do material manipulativo nas aulas. Essa prática ainda não é uma realidade em algumas salas de aula. Predomina a aula expositiva com uso apenas do registro no quadro. O paradigma do exercício (SKOVSMOSE, 2006) ainda não foi superado.

Professora Lu: observamos que desde que começamos com a coleção de tampinhas, a gente vem observando que o trabalho com o material concreto e flui melhor na questão da aprendizagem... a criança manipulando é melhor de aprender e de raciocinar... então assim a questão da contagem eu observei claramente a criança que tinha dificuldade de contar até 10 hoje já avançou... avançaram bastante... na contagem... na contagem de 10 em 10 eles estão bem... avançados

Destacamos ainda o uso dos jogos que vem aliado à resolução de situações problema. Algumas professoras já falavam sobre o jogo. A importância de promover o jogo na aula de matemática faz parte do discurso, mas realmente realizá-lo com uma intencionalidade educativa, como um espaço para aprender nem sempre ocorre. Nesse ponto disponibilizamos textos de Muniz (2014), principalmente o que foi produzido para o Caderno de Formação do PNAIC, em que o autor discute as possibilidades do jogo como potencializador da aprendizagem de conceitos matemáticos. 
As professoras destacaram o poder do jogo de fazer a criança concentrar-se, bem mais do que um pedido de silêncio.

Professora Jan: Mas uma coisa eu percebi eles estavam concentrados no jogo... participativos.. Eu tinha de correr de grupo em grupo... Jogava o dado e ai e eu dizia ajude o colega... três rodadas...sai suada...conseguimos fazer as três rodadas. Tiveram alunos que perceberam rápido e logo caia doze ele não ia mais nas tampinhas soltas ele logo pegavam o amarradinho e as duas soltas. Achei interessante. Outros não... contavam o que saia e pegavam uma a uma.

Enfatizamos que os conceitos, que antes eram explorados em situações estanques ou apenas no momento previsto para a aula de matemática, passaram a ser percebidos e instigados em diferentes situações de modo coerente com o que é defendido por Vergnaud (1990). Por exemplo, a professora Lu, no inicio da aula, aproveitava as crianças em fila para escrever uma operação de adição em que o total de crianças em cada fila seria somado para saber quantas estão presentes na aula. Isso era previsto no plano, mas era feito apoiado na contagem de um em um:

Professora Lu: colocar o total de cada fileira de crianças...que operação é essa...eu já pergunto assim?... o sinal de mais?... o que vou fazer?... vou juntar? E vamos fazer o total e ai registro no quadro... em que coluna coloco esse total? Nessa? só pode ir para outra se passar de nove! deu dezenove e coloquei dezenove na coluna das unidades... esse dezenove pode ficar aqui? Esses dois números podem ficar aqui juntos?... Ah tia vamos levar dezenove tem mais de 10 tem então esse 1 aqui é quanto é dez então ele irá para outra coluna...está trabalhando com os algoritmos sem ser só as continhas...sem precisar do arme e efetue..

Pesquisadora: Operações eles já resolviam o tempo todo... agora eles estão registrando o que aparece em as situações de sala de aula.

É relevante verificar as informações que podem ser obtidas a partir da reação demonstrada pelas professoras diante da percepção das aprendizagens das crianças. Observar e acompanhar a ação da criança é algo que realmente provoca mudanças na prática das professoras, pois, mesmo quando adotam posturas equivocadas, a intenção, principalmente daquelas que atuam nos anos iniciais, é ensinar e, se os modelos de ensino que antes eram legítimos hoje são questionados, necessário se faz pensar em que bases se construirá um novo modelo de ensino. As evidências nos fazem crer que em qualquer espaço formativo as produções das crianças são material de análise, material a ser estudado pelos professores como forma de tornar visível o potencial de aprendizagem da criança de mudar a dinâmica da aula, como inferimos das falas transcritas a seguir. 
Professora Jan: Na questão de perceberem o momento da troca quando chegava mais de nove tampinhas soltas também percebi a evolução muito grande em muitos... A turma toda não. Tem alguns que você pode colocar 20 tampinhas eles ainda não percebem que tem que trocar, mas são aqueles casos mas os colegas do grupo eles estão atentos... vamos trocar ...vamos fazer a troca... muitos estão bem já estão bem na posição do valor e como fazer as trocas

Professora $\mathrm{Lu}:[\ldots]$ por exemplo a Vitória não fazia relação uma a uma ( deu uma pega uma, nomeobjeto contado)..jogou deu oito... e agora vou pegar oito e colocar onde... nas soltas... dá pra trocar? não deu oito e agora vai fazer o que? faltam quantos para poder trocar?... preciso de $10 \ldots$ essa noção... essa percepção esse conhecimento de que preciso de 10 para mudar e trocar de ordem, de uma coluna das unidades para coluna das dezenas .. eles já estão fazendo naturalmente.

Professora Jan: Percebi que eles já não precisam mais de consultar a tabela numérica, eles antes eles faziam muito isso, não sabia qual era o numero eles tinham de ira a tabela procurar. Eles se ajudam quando um tem dúvida o outro diz é assim ..eles vão aos poucos se apropriando mesmo ...da contagem... do registro... até a própria dinâmica do trabalho em grupo, antes dava muito trabalho quando a gente diz, vamos formar as equipes... eles mesmo já se organizam...

Professora Lu: eles pegaram a ordem do quadro de registro, primeira parcela, segunda e terceira rodada vieram somando as unidades, depois as dezenas... e aí no final colocou o resultado. Fomos pegando o que estava no quadro de registro. Primeira rodada... pega doze... pegou dezena e unidades, segunda rodada pega onze... agora oito.

Pesquisadora: No depoimento de Jan em 31 de julho ela dizia que eles não sabem sentar eles não sabem brincar ainda. Olha a evolução em apenas duas semanas...

No encontro de dezembro de 2015, fizemos a avaliação final, do trabalho daquele ano e relacionamos o que faríamos no próximo ano. E, em 2016, como já relatamos no segundo capítulo, no qual descrevemos a dinâmica da pesquisa, o ano teve um início bem conturbado pelas ingerências da Secretaria Municipal de Educação. Entretanto, mesmo em meio a acontecimentos que desfavoreciam o nosso trabalho e pelo fato de estarmos envolvidas na construção da análise das informações constituídas em 2015, o trabalho continuou e as atividades vivenciadas em 2015 foram aperfeiçoadas. Isso foi evidenciado nos planos de trabalho em 2016.

No encontro realizado em maio de 2016, ao analisar o depoimento das professoras, conseguimos perceber os resultados das aprendizagens promovidas pela formação continuada em serviço, que foi realizada na escola no ano de 2015. É importante ressaltar que muitos dos conhecimentos de base, que deram suporte às mudanças reveladas na prática, foram construídos nos diferentes espaços de formação ocupados por essas professoras, ao longo de seu percurso profissional. Assim, acreditamos que durante a dinâmica da pesquisa- formação, realizada no período compreendido nos anos de 2015/2016, tenha ocorrido a oportunidade de fazer vir à tona essas aprendizagens, tanto em relação ao conhecimento do conteúdo, quanto ao conhecimento didático do conteúdo.

A dinâmica da pesquisa provocou a explicitação de algumas crenças e concepções que poderiam ser obstáculos para as aprendizagens e/ ou reaprendizagens que se integrariam à formação 
profissional e refletiriam mudanças na prática. Essas aprendizagens iriam auxiliar na superação do medo de adotar novas propostas de trabalho que exigiriam olhar para a matemática como uma área do saber fundamental no Ciclo de Alfabetização e, principalmente, pensar nesse conhecimento como acessível à criança de seis, sete e oito anos. Isso implicava tanto em ver a criança como um aprendiz em potencial, quanto a matemática como uma construção humana, que faz parte dos objetos culturais a serem apropriados por todos os sujeitos sociais, inclusive as crianças de qualquer idade, principalmente no espaço escolar.

Para discutir esse aspecto, encontramos em Thompson(1997) um estudo que revelou a existência de uma relação complexa entre as concepções dos professores(crenças, visões e preferências) sobre a matemática e a sua prática pedagógica. A autora chama a atenção dos pesquisadores sobre a necessidade de investigar de que forma essas concepções influenciam na forma como o professor trabalha com a matemática na escola. Outro estudo que nos ajudou a compreender essa possível relação revelada, em nossas informações de pesquisa, foi Curi (2005) e os autores por ela referenciados, pois ficou evidente que o que as professoras pensam sobre a matemática, sua aprendizagem e seu ensino refletia-se em sua prática. Em nossas experiências de formação, realizadas em diferentes contextos, nos deparamos com crenças e concepções que impedem, em alguns casos, que as professoras se abram a outras formas de mediação pedagógica, diferentes das formas tradicionais.

Nessa direção, pode-se ainda citar Nacarato, Mengali e Passos (2014), que trazem um estudo sobre a formação matemática da professora polivalente. Ao referirem-se as suas crenças e sentimentos, que se encontram subjacentes a algumas práticas, afirmam que:

\footnotetext{
Embora alguns autores façam classificações dos tipos de crenças, entendemos que, em se tratando de formação docente, elas precisam ser trabalhadas inter-relacionadas, pois se elas influenciarão o modo de se constituir professora, não há como separar as crenças dos diferentes saberes que compõem o repertório de saberes profissionais. O modo como uma professora ensina traz subjacente a ele a concepção que ela tem de matemática, de ensino e de aprendizagem. (NACARATO; MENGALI; PASSOS, 2014 p. 24, grifo nosso)
}

Em nossa pesquisa, observamos que o modo de ver a matemática e seu ensino poderia implicar em, por exemplo, não adotar uma prática como permitir o diálogo em sala de aula, incentivar a problematização das situações, instigar a dúvida, criar comunidades de aprendizagem como recomenda Nacarato $(2013,2014)$, pois isso exigiria, na visão das alfabetizadoras, um conhecimento aprofundado dos conteúdos matemáticos. E, como nem todas as professoras estabeleceram uma boa relação com a matemática, essa visão negativa interferia nas formas de pensar a aula de matemática e de aproximar a criança desse conhecimento. 
Assim, entendemos que a atenção às crenças e concepções é essencial a quem pretende atuar como formador de professores, tanto na formação inicial no curso de licenciatura, quanto na formação continuada, em diferentes projetos de formação, pois o formador, ao tomar como referência esses conceitos (ou preconceitos), poderá contribuir para que os professores superem esses obstáculos. Ignorá-los pode resultar em propostas de formação inócuas que não conquistam os professores e não os aproximam dos formadores, no sentido de vê-los como parceiros.

Reiteramos que nas falas das professoras é difícil separar os conhecimentos, principalmente os conhecimentos do conteúdo e os conhecimentos didáticos do conteúdo, pois a organização do trabalho pedagógico, que seria a expressão material do conhecimento didático do conteúdo, mantém uma relação muito direta com o conhecimento do conteúdo. A nosso ver, é explicita essa relação. Inferimos, com base no acompanhamento constante do trabalho que quanto maior o conhecimento do conteúdo e o conhecimento didático do conteúdo, mais criativo, mais envolvente, mais rico de experiências produtivas para as crianças se tornava o trabalho pedagógico das professoras.

Quanto ao conhecimento curricular, este às vezes mostrou-se restrito a ordem de apresentação dos conteúdos, sem avançar nas relações existentes entre eles. Conhecer o currículo de matemática dos anos iniciais é algo a que ainda vamos nos dedicar em nossa continuidade de trabalho.

Em síntese, a leitura das falas das professoras referentes às possíveis aprendizagens e reaprendizagens dos conteúdos, junto com a superação de crenças e concepções, nos levou a releitura dos resultados de educadores matemáticos. Essa releitura nos permite reafirmar o que esses pesquisadores constataram: os professores, desde os segmentos iniciais da educação básica, necessitam de uma sólida base de conhecimento.

Ademais, é válido destacar o que nos disse Muniz $(2016)^{30}$ ao referir-se à explicitação de conhecimentos produzidos pelas professoras: "a produção de conhecimento não se restringe aos estudos, mas a novas capacidades de captação das produções e de reflexões sobre os processos de aprendizagens movimentados nas aulas diferentemente pensadas e realizadas". Observamos que as fontes geradoras desses conhecimentos foram, principalmente, as discussões de problematização da prática, provocadas pelos questionamentos realizados nos diferentes momentos de formação, pela leitura dos livros ${ }^{31}$ disponibilizados para estudo, dos textos dos cadernos de formação do PróLetramento e do PNAIC, das orientações teórico-metodológicas contidas no manual do livro didático.

\footnotetext{
${ }^{30}$ Em reunião de orientação. Junho de 2016.

${ }^{31}$ Foram disponibilizados tanto os livros da pesquisadora quanto do acervo da Biblioteca do professor existente na escola que foram identificados e divulgados entre as participantes.
} 
Na próxima seção, serão apresentadas as informações direcionadas pelos questionamentos que impulsionaram as discussões, ilustradas por recortes dos planos de trabalho e das aulas gravadas em vídeo. Foi explícita a progressiva liberdade em transitar pelos conteúdos e em criar meios de promover a aproximação da criança com a matemática escolar, de modo que essa matemática fizesse sentido e os conceitos matemáticos aprendidos pudessem ser mobilizados em diferentes situações, tanto na escola como fora dela.

\subsection{A AMPLIAÇÃO DO CONCEITO DE ALFABETIZAÇÃO MATEMÁTICA, O DIÁLOGO TEORIA- PRÁTICA E A REORGANIZAÇÃO DO TRABALHO PEDAGÓGICO}

Os conhecimentos produzidos, referidos na seção 3.1, provocaram no grupo uma ampliação do conceito de alfabetização e, ao mesmo tempo, implicaram na reorganização do trabalho pedagógico. Referimo-nos à reorganização, pois o trabalho pedagógico das professoras já era organizado com base em um referencial que elas adotavam de forma consciente ou não. O que houve foi a adoção de uma forma diferente de organizar o trabalho a partir das discussões sobre a prática e das reflexões sobre o significado de alfabetizar em matemática.

E, para fins de análise, nesta subcategoria, identificamos e agrupamos os principais questionamentos que foram tratados em alguns dos encontros de formação. A atenção a estes questionamentos direcionou à reflexão problematizadora da ação em sala de aula e levou-nos às indicações de leituras que, junto com os conhecimentos produzidos na ação, deram suporte as discussões. Essa dinâmica pode ser ilustrativa da imbricação teoria-prática.

Figura 37 - Dinâmica entre a ação, a produção de conhecimentos, os questionamentos e os estudos

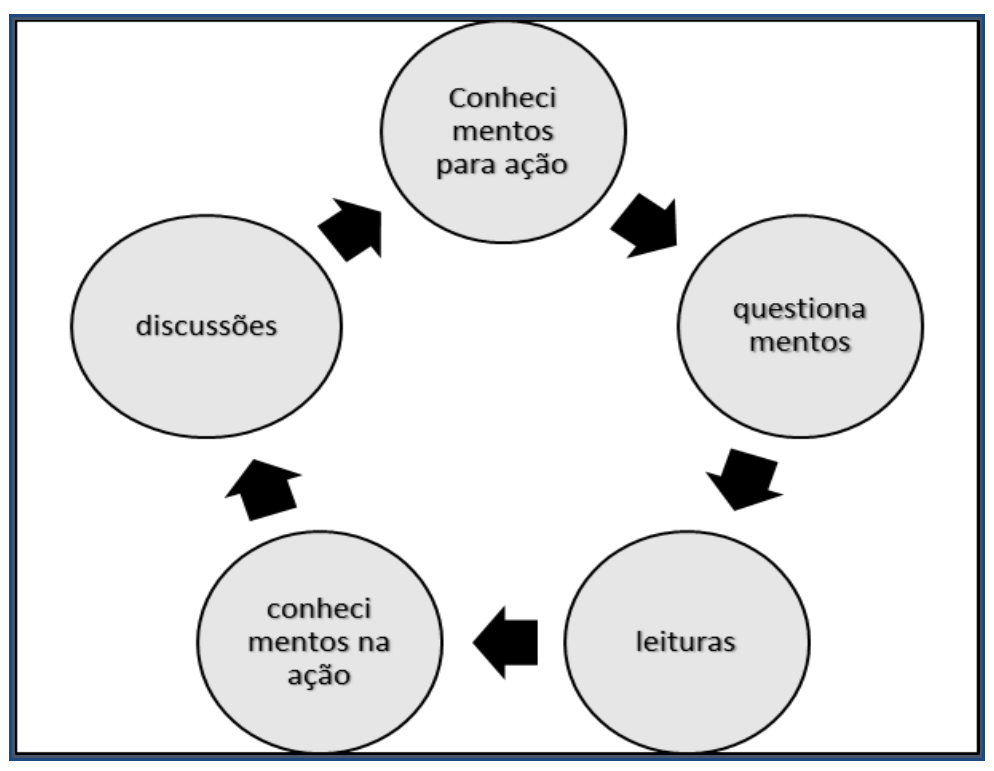

Fonte: elaborado pela pesquisadora. 
Neste espaço de análise, apresentamos apenas as questões mais expressivas e reveladoras do processo formativo, referentes: (i) à organização do trabalho pedagógico, (ii) à relação entre a aprendizagem da matemática, à avaliação diagnóstica e à análise dos erros e (iii) à organização curricular. Os principais questionamentos foram agrupados do seguinte modo:

$\checkmark$ Referentes à organização do trabalho pedagógico: De que modo podemos explicar a distância entre o pensado, o registrado no plano de trabalho e o realizado? Qual a forma de organizar o trabalho pedagógico durante a proposição de atividades diferenciadas? É possível minimizar "a bagunça” quando mudamos a organização tradicional da sala?

$\checkmark$ Referentes à relação entre a aprendizagem da matemática, a avaliação diagnóstica e a análise dos erros. O que a avaliação diagnóstica nos diz sobre a aprendizagem das crianças? O que sabemos sobre as avaliações externas? É possível ler os resultados das avaliações e direcionar o trabalho a partir da compreensão dos erros?

$\checkmark$ Referentes à organização curricular: Quais os conteúdos deveriam ser priorizados de julho a dezembro? O que devo explorar do eixo grandezas e medidas? O que faremos com a geometria?

As questões referentes ao conhecimento do conteúdo serão tratadas na segunda categoria, específica dos eixos de aprendizagem matemática.

\subsubsection{A reorganização do trabalho pedagógico}

Em relação às questões referentes à organização do trabalho pedagógico, inicialmente, chamamos a atenção do grupo de alfabetizadoras para algumas definições: - para qual segmento da educação básica se direciona o nosso trabalho; - o que significa alfabetização; - qual área de conhecimento será explorada especificamente neste trabalho? Essas definiçõos nos ajudaram a melhor situar o nosso trabalho e a direcionar a nossa busca de conhecimentos que não seriam aleatórios, mas, sim, adequados à situação em que estávamos inseridas. Talvez esse direcionamento tenha sido um elemento que proporcionou agilidade ao nosso processo formativo.

Como relatamos no segundo capítulo, as nossas primeiras observações tiveram como foco a dinâmica de elaboração de planos de trabalho. Com isso, foi possível conhecer o caderno em que eram registradas algumas propostas que poderiam compor esse plano. Essas propostas tinham, mesmo que não explicitamente, um referencial, que poderia ser alguma experiência já vivenciada ao 
longo da atuação profissional de cada professora, ser algo lido recentemente, ou algo discutido nos encontros de formação ocorridos nos anos anteriores. Havia uma teoria imbricada na prática.

Nos registros do caderno, estavam colocadas as intencionalidades que poderiam ou não acontecer em sala de aula, uma vez que naquele outro espaço físico (a sala de aula), diferentemente da sala de coordenação em que se encontravam profissionais adultos e alfabetizados e certos das melhores formas de agir, estava um grupo de crianças de 7 ou 8 anos (ou mais, os considerados em distorção idade/série), que nem sempre se encontravam na sala por uma decisão individual. Talvez estivessem ali por determinação da família e da sociedade e, nesse sentido, tinham de ser conquistados com boas propostas de trabalho e de ser incentivados a produzir conhecimentos. Era preciso, então, constituir com aquelas crianças um contrato didático e promover a devolução (BROUSSEAU, 1996).

Entretanto, entre o pensado e o realizado havia muito a se ajustar. O movimento dialético de tensão entre o pensado pela professora e o vivenciado pelo grupo - a professora com os mais diversos e diferentes alunos -, impelia a professora a produzir conhecimentos na ação e refletia o diálogo teoria-prática. As impressões, oscilações, necessidades, dúvidas e certezas eram explicitadas ou não nos momentos de discussão coletiva.

Em um dos encontros realizados em julho, após quatro meses de pesquisa, para incitar a discussão, propusemos como principal questionamento: De que modo podemos explicar a distância entre o pensado, o registrado e o realizado? A razão para formularmos esse questionamento está ligada ao fato de que víamos que mesmo com as evidências de aprendizagens das crianças, as reaprendizagens de algumas professoras, a tentativa de superação de crenças e concepções que obstaculizavam a adoção de novas práticas, ainda havia uma resistência em romper com posturas arraigadas. Isso ficava mais evidente quando a proposição de jogos e de diálogos com as crianças era inserida no plano.

Algumas professoras já faziam isso com tranquilidade, outras afirmavam não saber como “controlar a turma". As coordenadoras perceberam a ocorrência desse fato e conversamos sobre dar um tempo e não pensar que todas iriam caminhar no mesmo ritmo. Assim, após termos realizado dois encontros, em junho, que tiveram o formato de curso, com uma oficina proposta pela pesquisadora, entramos em recesso e, ao retornarmos, logo na primeira semana após o recesso, fizemos essas observações e convidamos o grupo a pensar sobre esse fato.

Uma grande inquietação que havia no grupo era relativa a como organizar o trabalho pedagógico para realizar jogos, pois no curso que tivemos em junho, estudamos o Sistema de Numeração Decimal a partir do Jogo Forme 10 (MUNIZ, 2014) e as operações de adição, 
subtração, multiplicação e divisão apoiadas nos agrupamentos de dez (MUNIZ, 2014; BERTONI, 2007). Nos primeiros meses de pesquisa, vivenciamos a euforia com a coleção de tampinhas, mas lembramos que eram apenas dois dias da semana, em dois horários após o intervalo, nos quais se trabalhava com a matemática, por isso o trabalho era bem compassado. Em julho, após o recesso, foram retomadas as coleções, as tabelas com as quantidades de tampinhas e ocorreram os problemas causados por essa mudança na organização da sala de aula: a sala ficou "tumultuada", as crianças eufóricas. Foram criadas estratégias individuais, cada professora em sua sala administrava a euforia das crianças, as vezes com a ajuda da coordenadora e da pesquisadora, nas classes mais numerosas.

No registro apresentado a seguir, pode-se inferir que as professoras passavam por uma transição: dar ou não liberdade as crianças?

\footnotetext{
Após o intervalo, como previsto no Plano, inicia-se o trabalho com a matemática. A professora informa o que será feito e afixa no quadro o cartaz em que estão registradas as quantidades de tampinhas trazidas pelos grupos em 14 e 15 de julho. Em seguida ajuda cada grupo a contar e registrar na tabela do grupo a quantidade trazida naquele dia. Isso leva tempo e torna-se visivelmente cansativo, pois conta-se a quantidade de cada criança e depois a quantidade total daquele dia. Como são quatro grupos de 3 a 5 crianças em cada implica em contar a quantidade de 20 crianças individualmente e de quatro grupos. Em um dos grupos, por exemplo, uma menina trouxe 97 e um menino trouxe 91 . Observa-se que a professora é quem segura cada tampinha, uma a uma em sua mão e coloca no saquinho. Mesmo não sabendo o nome de alguns números se as crianças tomassem para si esse desafio seria possível a professora ficar mais descansada....

- os alunos do $2^{\circ}$ ano mostram-se muito inteligentes e inquietos e querem fazer alguma coisa para ajudar a professora que repetiu várias vezes: "esperem ainda vou explicar".

- os agrupamentos de 10 só tiveram início depois da professora passar de grupo em grupo e contar de um em um. (Ver cartaz.. foto)

- As crianças sentaram-se no chão e formaram os grupos de 10 colocando as tampinhas no saquinho de fazer laranjinhas. E, surpreenderam ao mostrar que sabiam contar de $10 \mathrm{em} 10$. Um momento bem interessante foi quando um dos meninos mostrou agilidade em colocar as tampinhas no saquinho e após fechar três saquinhos juntou todos do seu grupo e contou 10 e 10 é vinte e mais vinte dá 40 e mais 10 é 50, mais 10 é???? É aquele ali tia apontando para a tabela numérica ( ver vídeo), como eu falo? Sessenta. Isso 60 já temos 60 . E aí são quantos grupos de 10? Seis de 10 que são... 60. (Vimos a expressão de felicidade da criança). (Interessante chamar a atenção para ideia de multiplicação presente nesta ação 6 de 10 ou 6 X 10).

(Registro de observação em diário de campo - Aula do $2^{\circ}$ ano - Vespertino Arquivo da pesquisadora, 2015)
}

As muitas exigências dessa forma de trabalho provocavam sentimentos contraditórios e às vezes exauriam as professoras. Podem ser essas evidências da estreita relação entre a forma e o conteúdo presente na base de conhecimentos das professoras. O que de fato poderia movimentá-las na reconstituição dessa base conhecimentos e contribuir na adoção de outra forma de organizar o trabalho pedagógico? 
Em meio as essas indagações percebemos que essa forma de organizar o trabalho pedagógico provocou um receio em relação ao trabalho com os grupos de 10, na proposição do jogo do Forme 10. Nesse contexto, no momento de discussão, a pesquisadora apresentou uma reflexão sobre os fatores que poderiam provocar a distância entre o planejado e o realizado e que dificultariam um melhor encaminhamento da aula de modo a torná-la menos exaustiva. Os registros, apresentados a seguir, mostram alguns trechos dessa discussão:

Figura 318 - Extrato do diário de campo 24 julho

Pesquisa: Prática pedagógica em alfabetização matemática - 24 julho.

1. Refletir sobre a distância entre o PLANEJADO (estudos/orientações didáticas/ desejos) e o REALIZADO (fatores objetivos e subjetivos)

2. Escrever sobre isso durante 10 minutos.

3. Expor oralmente o que escreveu e registrar no quadro:

A. Fatores dificultadores da aproximação entre o planejado e o realizado.

B. Formas para superação das dificuldades

Fonte: Arquivo da pesquisadora, 2015

Esse momento de reflexão foi fundamental em todo processo de pesquisa. Naquela ocasião, as nossas ações que estavam "a engatinhar" foram tomadas como objeto de análise e de confrontação de forma coletiva, com uma intensidade maior do que ocorrera antes. Afinal, importava-nos saber o que estávamos fazendo, em que medida nós desejávamos fazê-lo e em que essa ação nos ajudava em termos de desenvolvimento profissional. O questionamento que nos guiou foi: É apenas para aprender a alfabetizar em matemática de forma pontual ou os conhecimentos que supostamente estamos construindo serão integrados a nossa formação profissional? Os posicionamentos individuais iniciais ocorreram no sentido de diferenciar o planejado do realizado.

Professora Sam: O que é planejado é o que desejamos, o que idealizamos e queremos para nossas crianças. Isso é o que colocamos no plano. Mas, vários fatores dificultam a realização do que é planejado e sinto falta desde o começo de um tempo para avaliar/ refletir e replanejar e tornar a agir para superar a dificuldade. Além disso o currículo que é extenso. As aulas de informática/recreação são importantes, mas "quebram" o ritmo da aula e dispersam as crianças. O temperamento da criança. A visão da criança sobre o material. Eles acham que é brincadeira/ que o material é brinquedo. 
Como fatores que dificultavam a ação, as falas das professoras revelaram:

Figura 319 - Fatores que dificultavam a ação

1. O descompasso entre o tempo para a ação da criança e o tempo pensado, às vezes não é considerado o tempo que a criança precisa para fazer a atividade.

2. Indisciplina ???

3. Insegurança de "como fazer", algumas/muitas vezes, impede de desenvolver com mais ânimo, fascinação, determinação a aula.

Fonte: Arquivo da pesquisadora, 2015.

Para superar esse desafio, uma das formas possíveis propostas pelo grupo foi considerar uma possibilidade de apresentar uma solicitação formal à Coordenação pedagógica Geral da Secretaria Municipal de Educação. Nela estariam expostas as intencionalidades, as dificuldades, as sugestões para a superação das dificuldades e a solicitação de incluir melhorias na estrutura física da escola e na quantidade de crianças em sala de aula, de disponibilização de recursos materiais e o pedido de ampliação do tempo de coordenação pedagógica semanal, inclusive com um espaço adequado para a sala dos professores.

Nesse aspecto, após algumas discussões e ao se considerar a realidade da gestão municipal naquele ano, houve um consenso no sentido de priorizar, em 2015, mesmo com todas as dificuldades, as aprendizagens e o desenvolvimento profissional no interior da escola. Na sequência, em 2016, a partir dos resultados sistemáticos e dos registros obtidos com a realização da formação e implantação das mudanças no trabalho de sala de aula, haveria maior propriedade de argumentação, e o grupo poderia apresentar o trabalho e as solicitações à Secretaria Municipal de Educação, inclusive expor as exigências de políticas públicas que dessem apoio a essa forma de trabalho que estávamos experimentando.

Nesse encontro, ainda foram apresentadas como alternativas de superação da distância entre o planejado e o realizado:

1. Criar tempos na coordenação individual para essa avaliação e replanejamento. (90 minutos - como dividi-los?)

2. Definir o que é essencial no currículo.

3. Pensar em quais atividades podem ser propostas logo após a aula de informática e de recreação que acalme as crianças e dê continuidade ao trabalho. 
4. Dialogar com as crianças a fim de que elas entendam que mesmo com problemas diferenciados vindos de fora da escola, o "estar na escola" exige o cumprimento de regras. Têm-se um contrato que estabelece algumas normas de convívio social.

5. Lembrar que o uso do material não é o objetivo, o material é um recurso para atingir o objetivo.

6. Planejar um menor número de atividades para cada tempo de aula.

7. Dar tempo para a criança entender a atividade, fazê-la de modo experimental e fazê-la com segurança.

8. Buscar superar o modelo de "Eu explico - ele entende e faz exatamente o que espero".

9. Expor a proposta de trabalho a cada tempo de aula/ a cada atividade para que a criança compreenda e, ao envolver-se na atividade, diminua a indisciplina.

10. Realizar leituras sobre as bases teóricas que explicam o processo de formação de conceitos em matemática, de modo a encaminhar o trabalho de forma mais segura.

Registramos no quadro as observações de cada uma e convidamos o grupo a pensar no ideal e no possível. E, novamente, a questão do tempo de estudo coletivo ficou sem solução. A disposição da carga horária, realizada pela Secretaria Municipal de Educação, não prevê esse tempo e continuaríamos assim por todo o resto do ano. O engajamento, o compromisso do grupo e o bom relacionamento com a comunidade é que mantinham a disposição em realizar um trabalho coerente, mesmo que em algumas áreas ainda houvesse necessidade de aperfeiçoamento.

A partir dessas considerações propusemos que fosse realizada, no encontro seguinte, a leitura de um texto síntese em que relembramos como foi a organização do trabalho pedagógico até aquele momento, pois percebíamos que durante o recesso podia ter havido um resfriamento dos ânimos e precisávamos retomar os nossos objetivos:

Figura 20 - Parte do texto produzido pelas coordenadoras e pela pesquisadora 
PESQUISA: PRÁTICA PEDAGógICA EM ALFABETIZAÇÃo MATEMÁTICA - 31 julho

Ideias importantes para o trabalho: Da contagem de um em um para o Sistema de Numeração Decimal e o registro das operações.

A coleção de tampinhas nos ajudou a possibilitar a evolução na contagem de um em um e na identificação de quantidades. No caderno 3 do curso de formação do PNAIC vimos que:

\begin{abstract}
Atividades como a de fazer coleções devem ser estimuladas pelo professor alfabetizador dentro e fora da escola. Fazer coleções favorece o estabelecimento de metas, concepção de estratégias de êxito, formas de organização, classificação e, em especial, de contagem e controle das quantidades. Tal favorecimento é decorrente da forma como o professor organiza o recebimento e o arquivamento do material recebido por meio da contribuição dos alunos. As crianças podem fazer coleções de: figurinhas, pedras coloridas, sementes, tampinhas, entre outros objetos. ( p. 30)

Encontramo-nos agora as voltas com o registro da quantidade numérica e precisamos criar estratégias para que a criança compreenda a forma de registrar quantidades maiores do que dez. Julgamos necessário que a criança ao escrever 16(dezesseis) entenda que essa quantidade é dez mais seis. Que o dezesseis é uma quantidade maior do que dez e que por isso contem um grupo de

Estamos empenhados em superar a leitura mecânica dos números que mais adiante causa problemas ao ser necessário operar com quantidades maiores e realizar adições e subtrações com recurso. (agrupar ao somar e desagrupar ao subtrair). Entendemos que formar o dez é uma ação básica para compreensão do Sistema de Numeração Decimal. Como material de apoio para escrever uma orientação didática adotamos o Caderno 3 do PNAIC que trata especificamente dessa passagem da contagem para a representação com a utilização de algarismos.
\end{abstract} dez e mais seis elementos não agrupados.

Fonte: Arquivo da pesquisadora, 2015.

A nossa intenção era trazer algo escrito que falasse sobre o nosso percurso e que, ao mesmo tempo, nos aproximasse de materiais produzidos por pesquisadores na área de educação matemática. Nesse caso, os referencias foram: Muniz (2007, 2014) e Bertoni (1987, 2007), Zunino (1995), Panizza (2006), pois os conceitos matemáticos eram específicos do eixo de números e operações. Ao mesmo tempo, imbricados aos conhecimentos que deviam ser ensinados, tínhamos em mente os conhecimentos pedagógicos para ensinar e, para tanto, nos apoiávamos em Serrazina (2012), Nacarato, Passos e Grando (2014). Lembramos, conforme exposto no segundo capítulo (percurso metodológico), que os livros fontes de consulta ficavam à disposição do grupo. Esse movimento pode ter sido um diferencial importante para dinamizar e explicitar a relação entre teoria e prática.

Esse texto síntese foi lido em intervalos de tempo diferenciados e possíveis a cada uma, nos encontros de discussão coletiva e nos horários de coordenação individual entre 24 de julho e 14 de agosto de 2015. Nesses encontros, convidamos o grupo a retomar as expectativas de aprendizagem previstas para essa fase do Ciclo de Alfabetização o que poderia nos auxiliar na visualização dos propósitos de nosso trabalho:

- reproduzir, em atividades orais e escritas, sequências numéricas ascendentes e descendentes a partir de qualquer número dado;

- elaborar, comparar, comunicar, confrontar e validar hipóteses sobre as escritas e leituras numéricas, analisando a posição e a quantidade de algarismos e estabelecendo relações entre a linguagem escrita e a oral;

- reconhecer regularidades do sistema de numeração decimal;

- ordenar, ler e escrever números redondos $(10,20,30, \ldots ; 100,200,300, \ldots ; 1000,2000$, $3000, \ldots)$; 
- quantificar coleções numerosas recorrendo aos agrupamentos de dez em dez e demonstrar compreensão de que o dez está incluído no vinte, o vinte, no trinta, o trinta, no quarenta etc.;

- compreender o valor posicional dos algarismos na composição da escrita numérica, compondo e decompondo números. (BRASIL, 2014, p. 5 )

Essa retomada do que foi feito de março a junho de 2015 e dos objetivos de aprendizagem matemática que estávamos tentando alcançar nos ajudou a pensar em como encaminhar as próximas atividades. Acordamos que, se o grupo julgasse pertinente, iríamos inserir no plano o jogo do Forme 10, que tinha sido estudado em um dos encontros de junho. Porém, caso ele fosse avaliado como possível gerador de "desordem" na sala, poderíamos pensar em outra atividade. As professoras resolveram arriscar e juntas pensamos em como adaptar as fases do jogo de modo a que cada criança no grupo tivesse uma tarefa específica. Assim, o que foi definido coletivamente para ser colocado no plano foi:

Figura 21 - Adaptação do Jogo do Forme 10

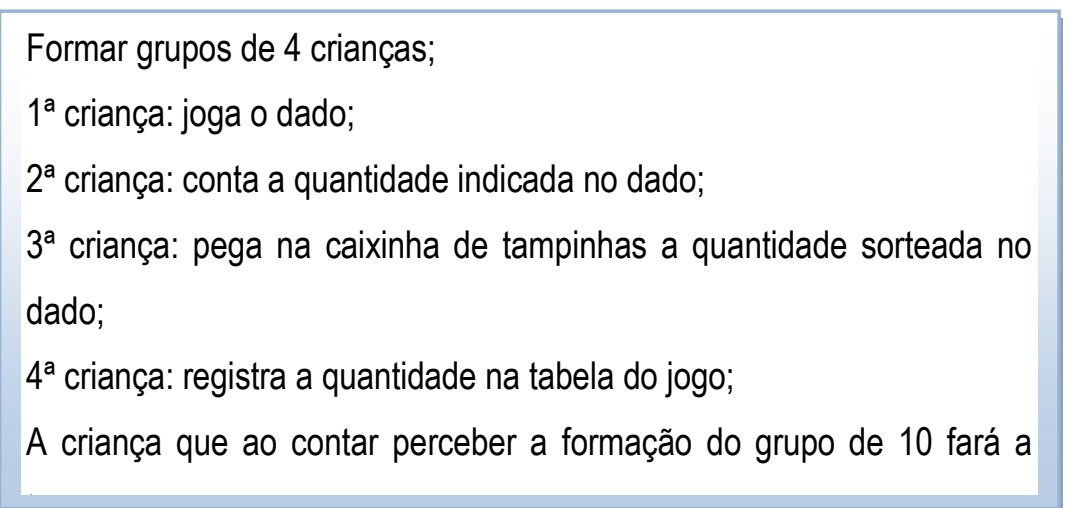

Fonte: Arquivo da pesquisadora, 2015.

Essa forma de organização tranquilizou as professoras e as crianças e logo se tornou desnecessária, pois, à medida que as crianças se envolveram com a proposta, elas se organizavam de forma mais autônoma. Isso foi percebido pelas professoras que se mostravam menos ansiosas com a proposição de jogos, principalmente ao ver que os conteúdos, no caso, a contagem, o sistema de numeração decimal e as operações eram explorados. Vimos sobre isso na seção 4.1, confirmado pela fala da professora Jan.

Nos momentos de coordenação individual, continuamos lendo trechos que descreviam os cenários de nosso trabalho, produzidos pela pesquisadora e pelas coordenadoras a partir das observações das aulas. Essa leitura nos ajudava a olhar para nossas aulas e nos situar e, de certa forma, parecia diminuir a distância entre o que planejávamos e o que realizávamos. 
Fizemos uma discussão voltada para as especificidades de cada ano, de modo a refletir sobre como encaminhar o trabalho com o número, o sistema de numeração e as operações:

Figura 22 - Anotações sobre como encaminhar o trabalho

Para o $2^{\circ}$ ano:

Um possivel caminho é colocar os grupos de 10 tampinhas formados pelas crianças sobre a plataforma, como mostra a figura:

\begin{tabular}{|l|l|l|}
\hline Amarradōes & Amarradinhos & Soltos \\
\hline & & \\
& & \\
\hline
\end{tabular}

Para o $3^{\circ}$ ano:

A formação dos grupos de $10 \mathrm{com}$ as tampinhas têm gerado algumas dificuldades, então vamos convidá-los a guardar a coleção de tampinhas e na aula de recreação e/ ou artes vamos juntos construir alguns objetos que serăo socializados na semana da criança em outubro. Vamos deixar as tampinhas e explorar os grupos de $10 \mathrm{com}$ o material dourado, pois temos um contexto bem particular que é o fato das crianças mudarem de escola ao concluirem o $3^{\circ}$ ano e temos a intençào de assegurar que a maioria mude de escola a dominar os conceitos de dezena e centena e, principalmente, a pperar com esses conceitos sempre que quantidades numéricas maiores que dez $\mathrm{e}$ maiores que cem apareçam em situaçōes aditivas e multiplicativas.

Fonte: Arquivo da pesquisadora, 2015.

Figura 23 - Sequência das anotações sobre o trabalho a desenvolver

Cenário 1: As crianças já contaram as tampinhas de um em um e nós professoras registramos em uma tabela as quantidades trazidas a cada dia de aula(dois dias na semana). E vamos contar o total de tampinhas (amarradinhos e soltos) ou podemos guardar o cartaz de registro e utilizá-lo, após a contagem de 10 em 10, para criar situaçõesproblemas e resolver as operações.

Cenário 2: Foi proposto as equipes que agrupassem de 10 em 10 para facilitar a contagem. Identificamos a quantidade de grupos de 10 formados pelas equipes. A professora diz as crianças: Vamos registrar no quadro quantos grupos de dez cada equipe formou? Primeiro: Quantos grupos de 10 tem a equipe 1 ? (Anotamos no quadro.)

Em seguida podemos perguntar: Se a equipe 1 formou 13 grupos de 10, isso quer dizer que ela já tem .... (130 tampinhas)/ (anotar no quadro). Lembrar que em outro momento irão contar (ou recontar) os soltos para conferir o total que está na caixinha de cada equipe.

Fonte: Arquivo da pesquisadora, 2015.

Para a organização do ambiente de sala de aula, inserimos um cartaz com os registros de quantos grupos de 10 cada pequeno grupo da sala de aula já tinha conseguido formar.

Figura 24 - Cartaz com o registro dos grupos de 10 formados pelos grupos

\begin{tabular}{|l|l|}
\hline Equipe 1: Francisca & \begin{tabular}{|l|} 
Equipe 2: Jancy \\
13 Grupos de 10
\end{tabular} \\
\hline 130 tampinhas & 110 tampinhas 10 \\
\hline
\end{tabular}

Equipe 3: Irani

9 grupos de 10

90 tampinhas

Fonte: Arquivo da pesquisadora, 2015 
Na sequência, continuamos a "olhar" as cenas de nosso trabalho em sala de aula, como pode ser verificado na figura 45, a seguir:

Figura 25 - Reflexão sobre as atividades a serem desenvolvidas em sala

Cenário 3: Vamos colocar os grupos de 10 sobre um tapete em que estão escritas as palavras: (explorar o valor posicional)

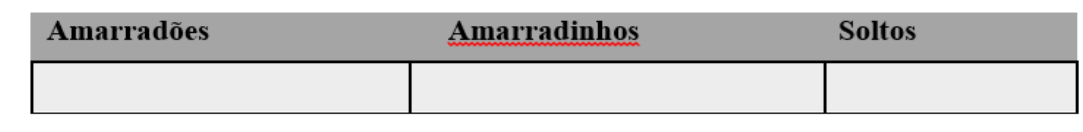

Observação: Na página 16 do caderno 3 do PNAIC vimos que: “ além da leitura dos números, a construção das terminologias Unidades, DEZenas, CENtenas devem ser trabalhadas de forma gradativa, construtiva e significativa, exploradas a partir do $2^{\circ}$ ano do ciclo de alfabetização".

Cenário 4: Propor o jogo do Forme DEZ. Durante e após o jogo serão propostas situações - problemas que servirão como contexto/pretexto para resolver operações sobre a plataforma, como vimos nas sugestões de Bertoni(1987, 2007) e $\operatorname{Muniz}(2007,2014)$.

Fonte: Arquivo da pesquisadora, 2015.

Os planos de trabalho, nesse período, acompanharam nossas reflexões e problematizações:

Figura 26 - Exemplo de plano de trabalho

\section{3 de agosto:}

- 2० momento: Cenário 4: Propor o jogo do "Forme DEZ" e seguir as orientações dadas pelos autores do Caderno 3 do PNAIC com adaptações de acordo com a nossa realidade. Durante e após o jogo serão propostas situações - problemas que servirão como contexto/pretexto para resolver operações sobre o mesmo tapete (plataforma)

Obs: A construção das terminologias UNidades, DEZenas, CENtenas devem ser trabalhadas de forma gradativa, construtiva e significativa, exploradas a partir do $2^{\circ}$ ano do ciclo de alfabetização.

"FORME" 10 - Como jogar e que aprendizagens ele pode proporcionar? (Caderno 3 e caderno de jogos Pnaic)

Fonte: Arquivo da pesquisadora, 2015.

Observamos que foi transcrito para o plano de trabalho de 03 de agosto o que foi escrito em nosso texto que continha o relato de nossas ações. Para nós, esse foi um momento importante, que precedeu o momento que denominamos de autonomia em que as professoras se utilizaram de suas próprias palavras para escrever o plano de forma coerente com suas novas concepções, ou dito de outro modo, de acordo com seus conhecimentos resultantes das novas experiências, reflexões, problematizações e teorizações que o espaço constituído dentro da escola estava oportunizando, principalmente pelo trabalho coletivo. 
As produções de março a junho de 2016, mesmo em um contexto desfavorável do ponto de vista do momento político em que nos encontrávamos na gestão municipal, podem ser avaliadas como produções autônomas e ser ilustrativas do caminho que percorremos de uma prática reiterativa à uma prática criadora.

A dinâmica relação entre teoria e prática, explicitada nesse trabalho, foi mais evidente em relação ao eixo números e operações. Esse fato foi previsto por nós que, em nossas experiências com formação de professores e em nossas leituras de resultados de pesquisa nessa área, conhecíamos, mesmo que de modo não sistemático, a realidade dos anos iniciais de privilegiar esse eixo. Por isso, apesar de não termos feito a opção em delimitar um único eixo de aprendizagem nesta pesquisa, o grupo definiu por seguir essa vertente, mesmo que não tenha sido explicitamente, e as nossas discussões foram mais profícuas em relação aos números e operações. Como visto, desde os primeiros momentos de pesquisa, as preocupações das alfabetizadoras centravam-se em como ensinar a sequência numérica e as operações. Essa informação será mais explorada na análise da segunda categoria.

\subsubsection{A avaliação diagnóstica e o aprender sobre o ensinar}

Os questionamentos referentes à relação entre a aprendizagem da matemática, a avaliação diagnóstica e a análise dos erros foram agrupados do mesmo modo: O que a avaliação diagnóstica nos diz sobre a aprendizagem das crianças? O que sabemos sobre o processo e os instrumentos das avaliações externas? É possível ler os resultados das avaliações e direcionar o trabalho a partir da compreensão dos erros?

Muitas são as informações que evidenciam os impactos dos resultados da avaliação diagnóstica sobre a prática das professoras. Esse foi um componente essencial em nosso percurso de aproximação a uma prática criativa e também ilustra a ligação entre a ampliação do conceito de alfabetização matemática, o diálogo teoria-prática e a reorganização do trabalho pedagógico. Um convite a ver os erros como indicadores de aprendizagem (BURIASCO, 2008) provocou uma mudança na direção do trabalho. E algo que faz parte de nosso discurso como professoras, formadoras, pesquisadoras e que parece tão óbvio, mostrou-se ainda carente de mais estudo. Por exemplo, o que de fato queremos dizer com a expressão: aprender com os erros dos alunos? Em quais referenciais nos apoiamos para sustentar a afirmação de que "realizamos uma avaliação diagnóstica"? 
Foram revelados conhecimentos que são informalmente produzidos pelas professoras na avaliação constante de suas crianças, mas que, por vezes, não são sistematizados e nem tomados como orientadores da prática. Nos referimos aos conhecimentos que são produzidos pela avaliação da aprendizagem. Pontuamos dois aspectos importantes desta ação que oportunizaram à equipe de trabalho olhar para a prática e tomá-la realmente como objeto de análise: os estudos sobre avaliação que, junto ao planejamento, foram elementos essenciais na constituição de uma práxis pedagógica; e a clareza da intencionalidade na elaboração de um instrumento diagnóstico.

Lembramos que, desde o momento em que iniciamos o trabalho junto à coordenação, percebemos um desejo de realizar um diagnóstico em matemática, pois na área de Português isso já era uma prática. Como informamos, o município promoveu cursos nesta área e disponibilizou orientações bem sistemáticas sobre como identificar os diferentes níveis de aprendizagem em relação à leitura e à escrita em português. Na escola, após essa identificação, faz-se o reagrupamento, em que crianças de mesmo nível de aprendizagem são atendidas em uma mesma sala com um trabalho diferenciado em que são propostas atividades específicas para cada nível. Esse reagrupamento ocorre antes do intervalo. As professoras seguem aquela distribuição semanal da carga horária e, nos tempos destinados à área de Português, as crianças assistem aulas em turmas reagrupadas. Isso, apesar de não termos dados de pesquisa, aparentemente tem funcionado. Essa proposta toma como referencial os estudos sobre psicogênese da língua escrita de Ferreiro e Teberosky (1984).

Vimos que um instrumento para diagnóstico em matemática foi elaborado pela coordenação e em março proposto para as turmas, mas o resultado não havia sido avaliado, pois haviam outras demandas mais urgentes. No início da primeira unidade (março-2015), algumas turmas estavam em remanejamento, professoras contratadas foram demitidas e turmas desfeitas e crianças deslocadas, inclusive com mudanças de turno. Em meio a todo esse movimento, a coordenação externou essa preocupação de, junto com uma especialista em educação matemática, realizar um adequado diagnóstico em matemática. Parecia haver um desejo de diagnosticar, classificar e, provavelmente, agrupar as crianças e realizar propostas de trabalho diferenciadas, como já acontecia em Português. Na área específica de alfabetização matemática, de certa forma, o reagrupamento seria incoerente com nossos referenciais, pois o que sustenta nossa ação é a perspectiva das trocas entre os pares em diferentes níveis de aprendizagem, de modo que um possa agir em contribuição a aprendizagem do outro. (VIGOTSKI, 2000)

No entanto, como ainda estávamos no início de nossa aproximação com o grupo, julgamos que, naquele momento, a melhor opção seria concordar e elaborar um instrumento diagnóstico, que 
poderia ser uma ótima oportunidade para discutir a avaliação e tornar visível as aprendizagens ou as não aprendizagens. Assim, convidamos a equipe de professoras a revisitar os textos disponíveis no Caderno 1 do Pnaic, em que as professoras Nacarato, Passos e Grando (2014) dispõem indicações sobre a organização do trabalho pedagógico e defendem que entre os momentos fundamentais dessa organização encontra-se a avaliação, que é parte integrante da aula, de forma contínua. Após discutir possíveis instrumentos que auxiliam o professor na avaliação, as autoras afirmam que:

\begin{abstract}
A avaliação vai ocorrendo ao longo do processo, seja pela observação sistemática e intencional do professor, seja pelos registros produzidos por alunos e professores. Espera-se que esses momentos de avaliação tenham sido registrados e que possibilitem replanejamentos ao longo do processo.

Esse trabalho sistemático possibilitará que o professor diagnostique as necessidades e avanços dos alunos em termos da Alfabetização Matemática e possa dar continuidade ao processo de ensino com vista à aprendizagem do aluno. Entendemos que no ciclo de alfabetização não faz sentido interromper o movimento de aprendizagem de sala de aula para realização de uma prova formal pelo professor. A avaliação precisa ser contínua e formativa. (NACARATO; PASSOS; GRANDO, 2014, p.39)
\end{abstract}

Indicamos também a leitura de Serrazina (2008, 2012) que discute o avaliar inserido na atividade de planificação. Especificamente, Serrazina (2008) traz um exemplo bem detalhado do tratamento dado a um conteúdo específico e a leitura que as professoras podem fazer dos registros feitos pelas crianças e como essa leitura pode direcionar os novos planejamentos. Mas, além de estudar os referenciais teórico-metodológicos sobre a avaliação da aprendizagem e suas implicações no ensino, como havia uma urgência por um instrumento de diagnóstico, um caminho tomado foi o de consultar os documentos que tratam da avaliação externa da Educação Básica: Provinha Brasil e ANA e buscar o instrumento de registro de avaliação interna - o Dossiê proposto pela equipe de Coordenação Pedagógica Geral da Secretaria Municipal.

A rede municipal de ensino não adota provas e usa um dossiê em que as aprendizagens esperadas já se encontram descritas em cada área e cabe ao professor observar o desempenho das crianças e assinalar no formulário próprio as aprendizagens que ocorreram em determinados períodos de tempo. Quanto às avaliações externas, buscamos responder as questões: a quais avaliações as crianças da rede municipal de ensino são submetidas? Em que tempo elas acontecem? Com qual periodicidade? Qual a participação das professoras da escola na dinâmica de avaliação externa? De que forma os resultados das avaliações externas são lidos? Esses resultados orientam na direção de novas práticas? E, na sequência, fizemos leituras dos documentos oficiais, disponibilizados pelo MEC sobre os instrumentos de avaliação externa.

Quanto a avaliação interna, buscamos informações junto a coordenação sobre: Como ela acontece? Quais os instrumentos utilizados pelas alfabetizadoras? Como é o acompanhamento da 
aprendizagem individual? Desde o início da pesquisa, atentamos ao calendário anual, em que estão previstos oficialmente os inícios e términos de unidades. São quatro unidades anuais e, nesse documento, ainda estão definidas as datas de realização dos Conselhos de Classe.

Com foco na ampliação de conhecimentos a ser realizada pelas alfabetizadoras, em um de nossos encontros, no mês de abril, colocamos como ponto de discussão o diagnóstico em matemática. Mesmo com um mínimo de tempo, expusemos em slides informações importantes contidas nos documentos sobre a Provinha Brasil e sobre a Avaliação Nacional da Alfabetização (ANA), pois os dossiês já eram bem conhecidos pelas professoras.

Observamos que as avaliações externas seguem a orientação a nível nacional. Encontram-se disponíveis no portal do INEP ${ }^{32}$ informações sobre o SAEB, um sistema de avaliação composto por três avaliações externas em larga escala: Avaliação Nacional da Educação Básica (Aneb), Avaliação Nacional do Rendimento Escolar (Anresc) /Prova Brasil e ANA. Interessou-nos especificamente esta última, pois trata-se de uma: "avaliação censitária envolvendo os alunos do $3^{\circ}$ ano do Ensino Fundamental das escolas públicas, com o objetivo principal de avaliar os níveis de alfabetização e letramento em Língua Portuguesa, alfabetização Matemática e condições de oferta do Ciclo de Alfabetização das redes públicas” (BRASIL, 2013).

Nos cadernos referentes a esse sistema de avaliação que chegam às escolas é possível encontrar informações essenciais para maior conhecimento deste sistema. A Aneb e a Anresc/Prova Brasil são realizadas bianualmente, enquanto a ANA é de realização anual e foi incorporada ao Sistema de Avaliação da Educação Básica em 2013, quando as preocupações com a alfabetização se tornaram mais evidentes e foi implementado o Pacto Nacional pela Alfabetização na Idade Certa.

O que ainda era questionado pelo grupo de professoras é a forma como esses instrumentos de avaliação chegam às escolas e como os resultados são tratados. O grupo de coordenação e professoras não dispõe de tempo suficiente para conhecer todo o processo.

No caderno denominado de Guia de Correção e Interpretação dos Resultados, enviado pelo INEP/MEC às secretarias municipais de educação e destas às escolas, encontramos informações importantes que poderiam ser lidas pelo grupo de alfabetizadoras, caso fossem instigadas a isso e, principalmente, caso houvesse tempo, além da consideração pela competência de cada profissional, em proceder a avaliação do seu grupo de alunos, o que poderia evitar a perda de oportunidades de produzir informações, pois como informa o Guia de Correção e Interpretação dos Resultados, a Provinha Brasil tem como principal objetivo "realizar um diagnóstico dos níveis de alfabetização dos alunos após um ano de estudos no ensino fundamental, de maneira que as informações

\footnotetext{
${ }^{32} \mathrm{http}: / /$ portal.inep.gov.br
} 
resultantes possam apoiar a prática pedagógica do professor em sala de aula" (BRASIL, 2015, p.4).

Caso houvesse um amplo estudo dos resultados da provinha, teríamos mais um elenco de dados para análise, que poderiam servir de referência para discutir a prática pedagógica. Em um dado momento do texto do Guia, é dito o quanto é importante que os professores conheçam o kit da Provinha Brasil, composto de: Caderno do aluno - questões a serem respondidas; Guia de aplicação - procedimentos para aplicação; Guia de correção e interpretação de resultados - orientação para correção e leitura dos resultados. Mais adiante neste mesmo caderno, encontram-se informações específicas sobre o teste: quem é avaliado pela Provinha Brasil? Qual o objetivo da Provinha Brasil? Como são os testes? O que é avaliado?

Quanto ao que é avaliado, informam-se as habilidades e competências estruturadas em uma Matriz de Referência de cada área. Têm-se uma matriz geral e uma Matriz de Referência comentada, em que são mais detalhadas as habilidades, chamadas de descritores de aprendizagem. O que se pode supor é que este Guia seja lido pela equipe de professores na escola e que este seja um material, produzido pelo INEP/MEC, que aproximaria a equipe de especialistas e a equipe de aplicadores, no caso as professoras das redes municipais de ensino.

Com a intenção de tomar como fonte de referência materiais que passaram pelo crivo de especialistas na área de educação matemática e, ao mesmo tempo, são disponibilizados em sites mais confiáveis, decidimos ter esses materiais como referência para a consulta/seleção de itens de avaliação.

No encontro do início de maio de 2015, definimos quais os conteúdos seriam avaliados e esses indicariam quais os itens, aprovados e contidos nos documentos oficiais, iriam compor o instrumento adotado pela escola. Isso não aconteceu de forma tranquila. As professoras tinham clareza do que queriam avaliar e cada item foi analisado e modificado, caso houvesse consenso, inclusive com a inserção de itens que não faziam parte dos itens já aprovados e que compunham a Provinha Brasil. Esse fato foi revelador do engajamento do grupo e, ao mesmo tempo, demarcou o espaço da profissional professora ao delimitar o que é próprio de sua função. Poderia ainda ser uma forma de sinalizar que seria avaliado o que foi planejado e desenvolvido, mesmo com a distância entre o desejado e o realizado.

Naquele momento de problematização, algumas revelações nos surpreenderam, como, por exemplo, as afirmações de algumas professoras ao apresentarmos o Guia de Aplicação e destacarmos alguns itens e os indicadores de cada item: 
Professora Lu: Nem observei isso (referia-se ao descritor do item) [...] a gente recebe a equipe da Secretaria Municipal de Educação... elas aplicam e levam os resultados, as vezes nós lançamos no sistema os gabaritos e devolvemos às crianças os cadernos de prova. É só essa nossa participação.

Mesmo conhecendo os resultados de pesquisa sobre esse aspecto, ainda foi surpreendente constatar essa realidade. Enfim, os itens que iriam compor o instrumento de avaliação foram definidos de acordo com os conteúdos que teriam sido ensinados na primeira unidade do ano de 2015.

Após a aplicação, procedemos à identificação do total de erros e acertos. Colocamos os resultados em um quadro, como exposto na figura 47. Cada professora recebeu esse quadro, com indicações do total de acertos e erros em cada item e com o quantitativo de acertos e erros de cada criança.

Figura 47 - Quadro de resultados da avaliação diagnóstica

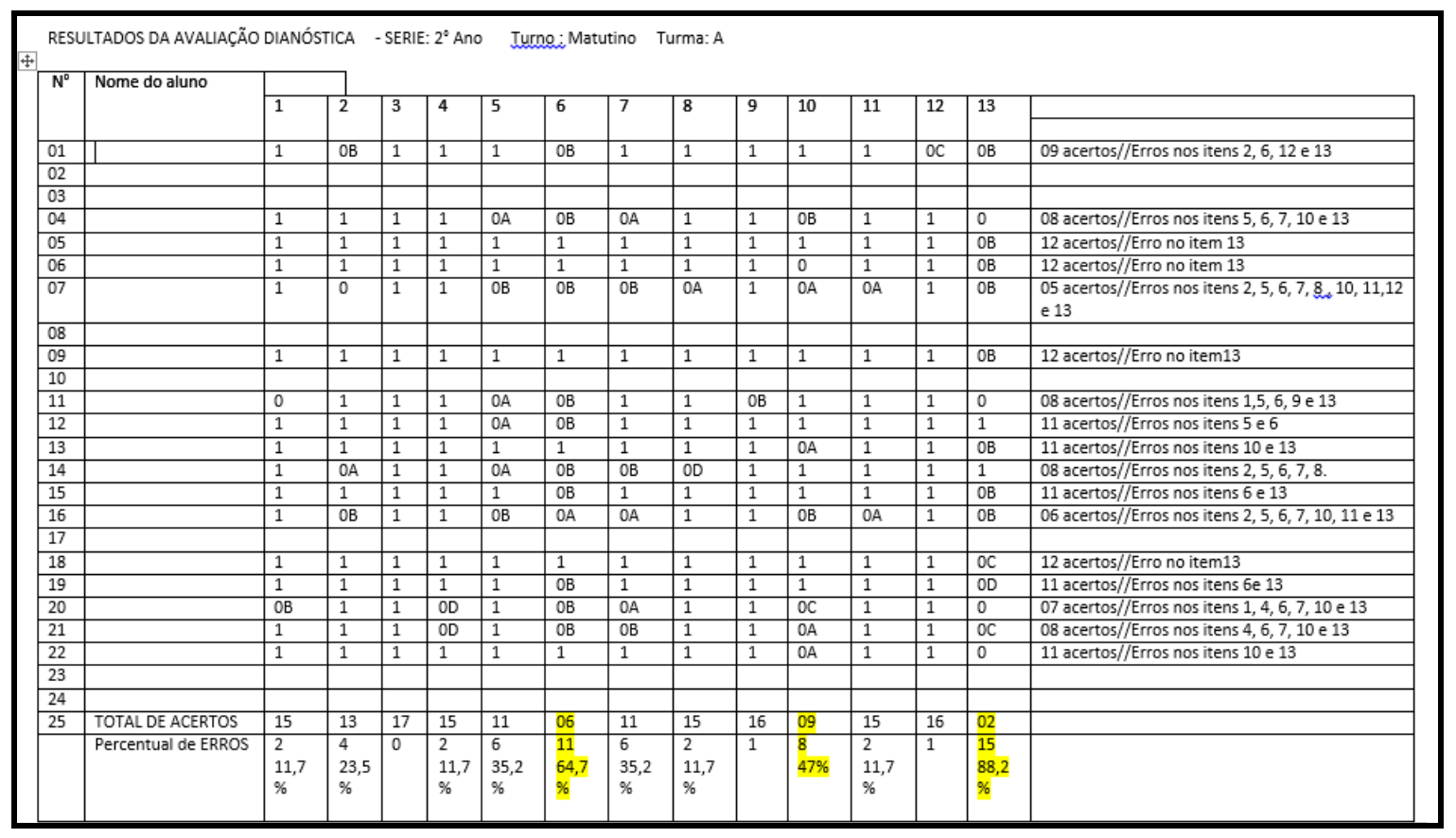

Fonte: Arquivo da pesquisadora, 2015.

A leitura dessas informações foi realizada num dos encontros de sexta-feira. Naquele momento, foi possível levantar hipóteses sobre o que pode ter gerado os erros e o que esses erros nos indicam em termos de reorganização do trabalho pedagógico para a continuidade dos estudos de cada eixo de conteúdos avaliado.

Lembramos que eram cinco turmas de $2^{\circ}$ ano e que os resultados foram semelhantes em quatro das cinco turmas. É importante ressaltar que as impressões das professoras, reveladas antes 
da aplicação do instrumento, foram confirmadas pelos resultados da avaliação, o que se considera uma evidencia de que há, mesmo que de modo assistemático, uma avaliação constante na sala de aula. Ainda não estava claro quais os instrumentos de avaliação eram utilizados, além da observação e das tarefas de casa. Apenas uma das turmas revelou-se com maior percentual de erros, apresentando maiores percentuais em 09 dos 13 itens em comparação com as outras quatro turmas. A professora mostrou-se muito preocupada e afirmou já esperar esse resultado. Ela fez uma descrição dos problemas identificados durante as aulas e toda a equipe concordou que uma assistência especial deveria ser dada àquela turma.

Em todas as cinco turmas do $2^{\circ}$ ano apareceram com percentuais de erros superiores a $30 \%$ para os itens 06 (Identificar informações apresentadas em tabelas), 10 (Identificar informações contidas em gráficos de colunas) e 13 (Indicar um numeral que está faltando em uma determinada sequência de números naturais.). Na turma da professora Jan, além desses itens, apareceram com percentuais de erros acima de 30\% os itens 04 (Associar a denominação do número à sua respectiva representação simbólica) e 07 (Resolver problemas que demandam as ações de juntar e acrescentar quantidades). A análise dos percentuais de erros em alguns itens foi reveladora da distância entre o conteúdo proposto para ensino, previsto no plano de trabalho, e o conteúdo aprendido pela criança. Mesmo ciente dos inúmeros fatores que podem interferir no processo de aprendizagem, os conteúdos dos itens com maior número de erros foram identificados como não aprendidos ou aprendidos parcialmente.

O fato de um instrumento formal, estudado, elaborado e aprovado em um encontro de discussão trazer dados sobre a aprendizagem impactou a equipe, mesmo porque os resultados foram bem semelhantes em quatro das cinco turmas do segundo ano e em duas das três turmas do terceiro ano em 2015. Ora, o planejamento era coletivo, supostamente todas as professoras estavam trabalhando em sintonia. Assim, os resultados mostraram que, mesmo com diferenciações no tempo e no modo de fazer, o fato de propor as mesmas atividades para explorar os mesmos conteúdos, o que de certa forma uniformizava o que seria aprendido, não garantia a aprendizagem semelhante para todos. Serão aqui ilustrados apenas três itens mais reveladores do processo de alfabetização relacionados a número e sistema de numeração decimal.

Figura 48 - Quarto item da avaliação

$2^{\circ}$ ano: Item 04: Associar a denominação do número à sua respectiva representação simbólica

Faça um X na alternativa do número TRINTA E DOIS.
(A) 23
(B) 32
(C) 203
(D) 302 
Fonte: Arquivo da pesquisadora, 2015.

A palavra - número trinta e dois deveria ser lida e traduzida para a sua representação simbólica (32). Em uma das turmas nove crianças erraram, entre estas cinco assinalaram a alternativa D (302) o que indica a escrita do número sem supressão do zero. Pesquisas mostram que essa é apenas uma fase na construção da escrita dos números (ZUNINO, 1995). A leitura desse erro provocou uma mudança na visão das professoras sobre o significado do processo de alfabetização. Enxergamos aí uma oportunidade de chamar a atenção das alfabetizadoras sobre a análise da produção escrita das crianças. Naquele momento, buscamos as indicações de Buriasco (2008) e apresentamos as professoras:

Uma das implicações da análise da produção escrita é a de o professor assumir o status de alguém que está identificando, analisando, levantando hipóteses, isto é, investigando a produção do aluno para conhecer o que ele sabe e quais são suas hipóteses sobre o assunto em questão. À medida que essa análise é realizada, os professores podem, entre outras coisas, refletir sobre o modo como estão conduzindo o ensino dos conteúdos em sala de aula, bem como sobre a importância do contínuo acompanhamento da aprendizagem no cotidiano escolar. Até porque, enquanto prática de investigação, a avaliação tem entre suas características mais relevantes o fato de poder contribuir com o desenvolvimento dos alunos à medida que possibilita que compreendam seus erros e busquem superá-los. (BURIASCO, 2008, p. 32)

Insistimos em que na resposta a este item, foi evidenciada uma etapa importante na construção da representação simbólica de uma quantidade. Sugerimos às professoras identificar quais foram as crianças e iniciar um trabalho com as fichas escalonadas. Esse é um material sugerido por Muniz (2014) no Caderno 3 do Pnaic, como recurso auxiliar para supressão do zero ao escrever, por exemplo, cinquenta e seis $(50+6)$, que pode em determinado momento ser escrito pela criança como 506. Várias atividades podem ser propostas a fim de ajudar na compreensão de que o algarismo 5 escrito à esquerda do algarismo 2 já é suficiente para ter o valor 50, sem que seja necessário escrever o zero. Observamos ainda que entre as nove crianças que erraram nessa turma, três crianças assinalaram a alternativa A (23) o que pode ser indicativo de uma inversão na escrita entre 32 e 23 e que pode ser algo implicado na compreensão do valor posicional.

Outro item em que a resposta é ilustrativa desse mesmo processo de apropriação da representação simbólica foi o item 07, selecionado para avaliar a habilidade de resolver problemas aditivos. A análise da resposta mostra que a adição foi realizada corretamente, mas a escrita do número foi feita de modo incorreto e implicou em assinalar a alternativa incorreta: 
Figura 279 - Avaliação do segundo ano: sétimo item

$2^{\circ}$ ano: Item 07: Resolver problemas que demandam as ações de juntar e acrescentar quantidades.

Em uma caixa, João colocou 14 bolas e Rafael colocou 9.

Faça um $\mathrm{X}$ na alternativa que mostra quantas bolas foram colocadas na caixa.
(A) 19
(B) 203
(C) 23
(D) 21

Fonte: Arquivo da pesquisadora, 2015.

Esse item, aparentemente simples, exigia a identificação das quantidades de João (14 bolas) e de Rafael (9 bolas) e, na leitura do enunciado, seria identificada a pergunta: quantas bolas foram colocadas na caixa, o que indicava a realização de uma soma $(14+9=23)$. Em uma das turmas, entre 23 crianças, treze erraram e, entre as treze, oito assinalaram a alternativa B (203) a resposta era a alternativa C (23). Esse dado parece-nos um indicativo de que a operação foi realizada corretamente e faltou a essas crianças o domínio da escrita do número 23.

Observa-se que novamente a hipótese de que é preciso manter o zero intercalado na escrita da dezena prevaleceu. Se considerarmos como correta a escrita de 203 (20 e 3), o número de erros diminui para cinco. As crianças efetuaram corretamente a adição e apenas escreveram “incorretamente" o número 23. Esse resultado ajudou-nos a reforçar a ideia da alfabetização como um processo, uma aproximação da criança à linguagem matemática em que é preciso dar as crianças diferentes oportunidades de agir e representar as suas ideias com o uso dos símbolos próprios dessa linguagem.

Nos momentos de discussão desses resultados, observamos as expressões do tipo:

Não é apenas propor a questão e pronto! Temos então de observar, esmiuçar as respostas! Isso é difícil! Exige tempo!!

Não posso avançar na adição, ou melhor posso, mas atenta as escritas das respostas, pode ser que eles ainda tenham dificuldade com o registro escrito!!

Deixo o registro escrito de lado, valorizo só a fala? É isso?

Tenho de avaliar o tempo todo?!!

A leitura das respostas a um dos itens do instrumento de avaliação, do terceiro ano, também provocou discussões importantes nesta mesma direção: 
Figura 50 - Avaliação terceiro ano: sétimo item

$3^{\circ}$ ano: Item 07. Compreender o valor posicional dos algarismos na composição da escrita numérica, recorrendo aos agrupamentos de dez em dez.

No jogo Forme Dez, Mariana conseguiu a quantidade de palitos colocada no quadro como mostra a figura:

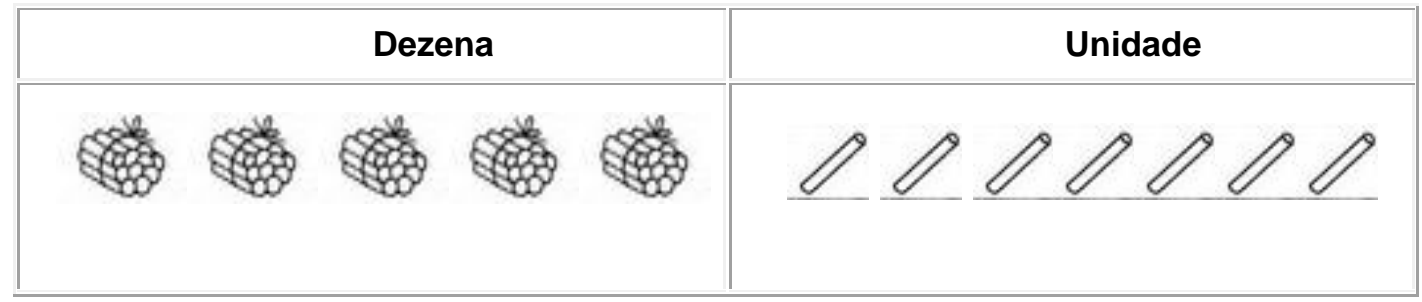

A quantidade de palitos de Mariana é:
(A) 12 .
(B) 57
C) 75
(D) 507

Fonte: Arquivo da pesquisadora, 2015.

Esse item foi proposto pelo grupo de professoras e o indicador foi escrito no momento da discussão/elaboração do instrumento. Ele avaliou uma das habilidades que integra o eixo de números: compreender o valor posicional dos algarismos na composição da escrita numérica, recorrendo aos agrupamentos de dez em dez. Os percentuais de erros variaram de 26,9\% a 52,1\% de erros. Em uma das turmas, doze crianças erraram. Todas assinalaram a alternativa A (12 que resulta da soma de $5+7$ ) o que evidencia o não reconhecimento dos cinco agrupamentos de 10 , como $10+$ $10+10+10+10$ que fazem o total de 50, que somadas com 7 unidades resultaria em 57 (alternativa correta B).

Esse resultado também impactou a equipe, pois o conteúdo centena já havia sido trabalhado pelas professoras do $3^{\circ}$ ano. Foi reforçada a necessidade de pensar sobre a prática, sobre o ensinar, sobre o tempo de aprendizagem e sobre as situações que promovem ou não essa aprendizagem. Além de estudar mais a respeito do conceito de número, concordamos em fazer uma pesquisa de atividades que poderiam contribuir para explorar as características do sistema de numeração decimal, principalmente o conceito de unidade, dezena e centena. Seriam privilegiadas as situações de contagem, os agrupamentos de 10 em 10 até formar 10 grupos de 10, o posicionamento dos agrupamentos na plataforma, de modo a visualizar a posição.

Interessou-nos muito a discussão/reflexão gerada por essa ação: construção coletiva de um instrumento de avaliação diagnóstica, leitura/análise coletiva dos resultados. Ou seja, o nosso foco recai sobre o que a análise do diagnóstico provocou nas alfabetizadoras, no sentido de se atentarem para o lugar da avaliação na constituição da sua prática e para como os conhecimentos produzidos na leitura das produções das crianças são conhecimentos base para organização curricular e organização/reorganização do trabalho pedagógico. Além disso, elas puderam refletir sobre como 
as leituras relacionadas à forma em que cada conteúdo foi gerado historicamente e no modo como pode sofrer a transposição para a sala de aula são de fato importantes.

Isso nos obriga a ter tempo para dedicar-se ao que Artigue (2001), na engenharia didática, denomina de estudos preliminares sobre o objeto matemático em estudo, em que são considerados: conhecimentos teóricos e didáticos existentes sobre o objeto; a epistemologia dos conteúdos a ensinar; o desenvolvimento do ensino e seus efeitos, inclusive a concepção, dificuldades e obstáculos dos alunos e os entraves didáticos pedagógicos que podem causar dificuldades no processo de ensino e aprendizagem.

Atentamos também ao que Serrazina (2012) defende entre os aspectos a considerar no processo de lecionação e pós-lecionação: valorizar os raciocínios dos alunos, olhando os processos desenvolvidos por estes; considerar o erro e explorar as suas razões; reconhecer e aproveitar capacidades evidenciadas pelos seus alunos; interrogar-se sobre as aprendizagens matemáticas realizadas, ou não, pelos seus alunos; reconhecer surpresas que eventualmente aconteceram na aula e tentar compreendê-las, - identificar aspetos que dificultaram o seu ensinar.

Assim, as análises dos resultados em cada item, principalmente esses aqui destacados, provocaram dúvidas e incertezas quanto à relação ensinar - aprender. Nesse sentido, insistimos em fazer pensar/problematizar a nossa práxis. Por se tratar de avaliação e por ter sido feita a leitura a partir do percentual de erros, sugerimos ao grupo como referencial para estudo o livro organizado por Buriasco (2008), que nos convida a pensar a avaliação de outra forma e nos orienta no sentido de olhar o que os nossos alunos já aprenderam e o que ainda falta a ser aprendido. É um convite a olhar o erro de outra forma.

Nos posicionamentos de cada professora, durante o encontro, em que os resultados foram discutidos, e nos encontros seguintes foi possível perceber uma preocupação em entender melhor a relação entre o ensino e a aprendizagem. A prática foi mais intensivamente tomada como objeto de análise. A função de ensinar, discutida por Roldão (2007), foi colocada em destaque. Era perceptível essa indagação: “Eu ensinei! Como eles não aprenderam?”. Sabemos que essa relação não é direta, diversos são os fatores implicados entre no ensinar e aprender. A provocação da leitura dos resultados fez vir a tona essa reflexão.

Afinal, a realização do diagnóstico por meio dessa atividade nos fez pensar na especificidade da função professora: o que é próprio do trabalho da professora alfabetizadora? Qual seria a melhor forma de pensar sobre a alfabetização? A nossa prática estava realmente voltada para a autonomia intelectual da criança? O que nós sabíamos sobre a criança em processo de alfabetização? Todas as crianças tinham vivências com situações matemáticas? Essas vivências 
eram exploradas em sala de aula? O que estávamos propondo às nossas crianças para a ampliação dos conhecimentos já construídos fora da escola e ainda a serem sistematizados no contexto escolar? Com o nosso trabalho era possível promover a aproximação entre o conhecimento espontâneo e o conhecimento científico? Quais as condições de trabalho? Os recursos materiais eram garantidos às professoras alfabetizadoras para que pudessem realizar um trabalho que oportunizasse às crianças uma aprendizagem para a vida?

É importante informar que os instrumentos propostos, em maio e outubro de 2015, foram elaborados pelo grupo de professoras, junto com as coordenadoras e a pesquisadora, com consulta e adaptação a itens já validados e disponíveis em banco de itens. Em 2016, foram propostos no início do ano três instrumentos de avaliação: um proposto pelo grupo de alfabetizadoras, junto com as coordenadoras, realizado para diagnosticar a área de matemática do mesmo modo como faziam com a área de Português, aplicado às turmas de $2^{\circ}$ e $3^{\circ}$ ano; um proposto pelas formadoras do programa Pacto Estadual ${ }^{33}$ para coletar dados sobre as turmas das professoras cursistas e a Provinha Brasil, aplicada às turmas do $2^{\circ}$ ano, por fazer parte de um programa nacional. Não foi nosso objetivo discutir essa quantidade e superposição de instrumentos de avaliação. Mas essas informações podem ser reveladoras da falta de sintonia entre as políticas públicas estaduais e federais e, principalmente, a desconsideração ao trabalho realizado pelo grupo de profissionais na escola.

No entanto, a fim de contribuir com o trabalho das alfabetizadoras, de igual modo, procedemos à leitura dos resultados, com a identificação do percentual de erros e acertos e com a leitura dos erros como evidências do processo de aprendizagem. Mesmo com a não participação na elaboração do instrumento, as professoras envolveram-se e demonstraram empenho em ler os resultados e em identificar as aprendizagens, o que nos indica uma maior consideração da avaliação como elemento essencial na constituição da prática. Elas mostraram-se muito mais atentas aos resultados desses instrumentos, mais preparadas para fazer a leitura dos indicativos de aprendizagens, o que pode ser fruto do processo formativo vivenciado em 2015, no envolvimento das ações de pesquisa e formação.

Assim, visualizamos um processo dinâmico, contínuo e cíclico que tentamos ilustrar na figura 5: o permanente diálogo teoria-prática, incitado pelas discussões, reflexões e problematização da prática, impeliu à busca/produção de conhecimentos, provocou a ampliação do conceito de alfabetização e implicou na reorganização do trabalho pedagógico.

\footnotetext{
${ }^{33}$ Programa Pacto Estadual: Programa de formação continuada para os alfabetizadores, oferecido pelo governo do estado da Bahia desde 2015.
} 
Figura 281 - Imbricação do diálogo entre teoria e prática, ampliação de conhecimentos e reorganização do trabalho pedagógico

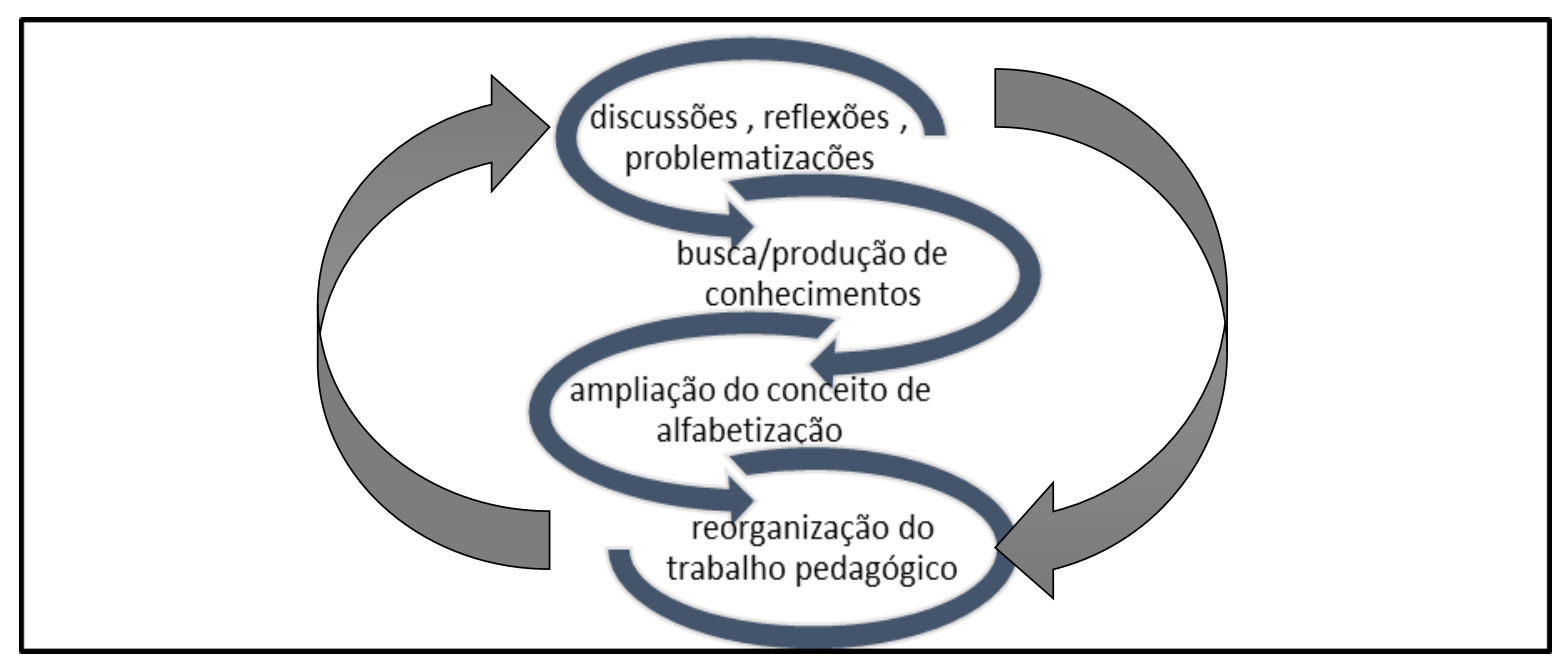

Fonte: elaborado pela pesquisadora.

Lembramos que, como discutido no primeiro capítulo, a alfabetização é muitas vezes restringida à aprendizagem da língua materna: a leitura e escrita na área de Português. Esse foi um desafio: convidar as alfabetizadoras a pensar que a alfabetização se dá em várias áreas do conhecimento, inclusive a Matemática. Ler, falar, pensar sobre a possibilidade de alfabetizar em diferentes áreas provocou a busca de constituir um novo referencial de base para a ação em sala de aula, o que revelou não haver uma dicotomia entre teoria e prática e, sim, uma imbricação entre esses dois elementos, numa constante retroalimentação: as discussões sobre a prática implicavam em buscar explicações para indagações que surgiam e o acesso a essas possíveis explicações tanto geravam novas práticas quanto outras indagações que exigiam mais conhecimentos, num contínuo processo de formação e mudança.

\subsubsection{A formação continuada e as mudanças na organização curricular}

Recordamos que a organização do trabalho pedagógico, nessa escola, prima por seguir as orientações curriculares expostas na Proposta Curricular do Município, como já descrevemos no segundo capítulo. Entretanto, iremos nos atentar ao modo como as aprendizagens, a ampliação do conceito de alfabetização e o diálogo teoria - prática, possibilitados pelo engajamento do grupo no espaço de discussão, geraram os questionamentos referentes à organização curricular: Quais os conteúdos deveriam ser priorizados de julho a dezembro? O que devo explorar do eixo grandezas e medidas? O que faremos com a geometria? 
Na seção 4.1, ao analisarmos as aprendizagens reveladas nos depoimentos das professoras, destacamos o modo compartimentado de ver os conteúdos, uma visão que ainda necessita ser superada, mas que implica no modo de organizar o currículo e influencia na tomada de decisão sobre quais conteúdos serão priorizados quando se tem em conta o fator tempo. Em nossa pesquisa-formação, o tratamento dado aos conteúdos, à medida que avançamos no processo formativo, foi forte evidência da relação entre a formação continuada e a práxis.

Dois momentos foram bem esclarecedores quanto ao posicionamento das professoras frente ao gerenciamento da ação de ensinar. Trata-se dos momentos de definição do conteúdo a ser ensinado no $2^{\circ}$ ano e no $3^{\circ}$ ano: em junho de 2015 e em maio de 2016 . Ao final de junho de 2015, após quatro meses de trabalho coletivo, em um dos encontros, dedicamos um tempo para discutir quais os conteúdos seriam priorizados a partir de julho, após o recesso, uma vez que as aprendizagens e a tentativa de superação de velhas crenças exigiam tempo para amadurecimento e alguns conteúdos já trabalhados seriam retomados.

Quadro 3 - Organização de conteúdos/ junho de 2015

\section{TURMAS DE SEGUNDO ANO}

Julho: 13 a 31 de julho - 06 aulas de matemática:

Continuar a contar as tampinhas e a agrupar de 10 em 10 e explorar o conceito de unidade e dezena com o Jogo do Forme Dez: agrupamentos e trocas.

\begin{tabular}{|c|c|c|c|c|}
\hline JULHO 6h/a & AGOSTO 8h/a & $\begin{array}{l}\text { SETEMBRO } \\
8 \mathrm{~h} / \mathrm{a}\end{array}$ & $\begin{array}{l}\text { OUTUBRO } \\
7 \mathrm{~h} / \mathrm{a}\end{array}$ & NOVEMBRO 8h/a \\
\hline $\begin{array}{l}\text { Operação de } \\
\text { Adição } \\
\text { Sistema de } \\
\text { numeração } \\
\text { decimal: } \\
\text { Unidade e } \\
\text { Dezena }\end{array}$ & $\begin{array}{l}\text { Operação de } \\
\text { Multiplicação } \\
\text { Dobro, triplo, } \\
\text { metade } \\
\text { Contar de } 2 \text { em } 2, \\
3 \text { em } 3 \\
\text { Resolução de } \\
\text { Situações-problema } \\
\text { Leitura de tabelas e } \\
\text { gráficos }\end{array}$ & \multicolumn{2}{|c|}{$\begin{array}{l}\text { Operação de subtração } \\
\text { Resolução de situações- } \\
\text { problema } \\
\text { Sistema monetário } \\
\text { Medidas de comprimento }\end{array}$} & $\begin{array}{l}\text { Operação de divisão } \\
\text { Formas não-planas: } \\
\text { identificação/ caracterização } \\
\text { Formas arredondadas } \\
\text { Planificação das formas } \\
\text { geométricas }\end{array}$ \\
\hline
\end{tabular}

Julho: 13 a 31 de julho - 06 aulas de matemática:

Continuar a contar as tampinhas e a agrupar de 10 em 10 e explorar o conceito de unidade, dezena e centena. (trabalhar com o jogo do forme dez).

Em agosto iniciar o trabalho com o material dourado para explorar as operações de multiplicação, subtração e divisão.

\begin{tabular}{|c|c|c|c|c|}
\hline JULHO 6h/a & AGOSTO 8h/a & $\begin{array}{l}\text { SETEMBRO } \\
8 \mathrm{~h} / \mathrm{a}\end{array}$ & $\begin{array}{l}\text { OUTUBRO } \\
7 \mathrm{~h} / \mathrm{a}\end{array}$ & NOVEMBRO 8h/a \\
\hline $\begin{array}{l}\text { Operação de } \\
\text { Adição } \\
\text { Sistema de } \\
\text { numeração } \\
\text { decimal: } \\
\text { Unidade, } \\
\text { Dezena e } \\
\text { centena. }\end{array}$ & $\begin{array}{l}\text { Operação de } \\
\text { Multiplicação } \\
\text { Medidas de Massa } \\
\text { Geometria: Formas } \\
\text { espaciais (2h/a) }\end{array}$ & \multicolumn{2}{|c|}{$\begin{array}{l}\text { Operação de subtração } \\
\text { Tabelas e Gráficos } \\
\text { Geometria: formas espaciais } \\
\text { Medidas de comprimento } \\
\text { Situações problemas } \\
\text { envolvendo a adição, } \\
\text { subtração, multiplicação. }\end{array}$} & $\begin{array}{l}\text { Operação de divisão } \\
\text { Geometria: } \\
\text { Formas Planas } \\
\text { Simetria } \\
\text { Medidas de tempo - } \\
\text { Dezembro ( } 4 \mathrm{~h} / \mathrm{a})\end{array}$ \\
\hline
\end{tabular}


Fonte: Arquivo da pesquisadora, 2015.

E, como relatamos no segundo capítulo, o ano de 2016 iniciou em meio a muita instabilidade e as atividades nos meses de março e abril foram descontínuas. Apenas em maio conseguimos reiniciar nossos encontros de formação. As professoras estavam participando do curso de formação continuada, oferecido pela Secretaria Municipal em adesão ao Programa Pacto Estadual. Ao final da segunda semana de maio, após a retomada de nossas discussões sobre a prática pedagógica em alfabetização, definimos os conteúdos que seriam priorizados de maio a julho de 2016.

Quadro 4 - Organização dos conteúdos/ início de maio de 2016

\begin{tabular}{|c|c|c|}
\hline Mês & Conteúdos & Observações \\
\hline $\begin{array}{c}\text { Maio } \\
\text { De } 17 \text { a } 31 \text { de maio } \\
7 \mathrm{~h} / \mathrm{a}\end{array}$ & $\begin{array}{l}\text { Contagem e exploração da sequência } \\
\text { numérica } \\
\text { Sistema de numeração decimal: } \\
\text { unidade e dezena Operação de adição } \\
\text { Grandezas e Medidas* } \\
\text { Estatística* }\end{array}$ & $\begin{array}{l}3^{\text {a }} \text { semana: } 17,18,19 \\
4^{\text {a }} \text { semana: } 24,25,26 \text { e } 31 \\
\text { * Delimitar os conteúdos } \\
\text { destes eixos. }\end{array}$ \\
\hline $\begin{array}{l}\text { Junho } \\
01 \text { a } 30 \text { de junho } \\
14 \mathrm{~h} / \mathrm{a}\end{array}$ & $\begin{array}{c}\text { Sistema de numeração decimal: } \\
\text { unidade e dezena } \\
\text { Operação de multiplicação } \\
\text { Grandezas e Medidas* } \\
\text { Estatística* }\end{array}$ & $\begin{array}{c}\text { Aulas as terças, quartas e quintas } \\
* \text { Delimitar os conteúdos destes } \\
\text { eixos. }\end{array}$ \\
\hline $\begin{array}{l}\text { Julho } \\
01 \text { a } 29 \text { de julho } \\
9 \text { h/a }\end{array}$ & $\begin{array}{c}\text { Operação de subtração } \\
\text { Geometria* }\end{array}$ & $\begin{array}{l}\text { Aulas as terças, quartas e quintas } \\
\text { Recesso: } 11 \text { a } 15 \text { de julho } \\
\text { * Iniciar a exploração dos } \\
\text { conteúdos deste eixo, após os } \\
\text { encontros de formação previstos } \\
\text { para junho. }\end{array}$ \\
\hline
\end{tabular}

Fonte: Arquivo da pesquisadora, 2016.

Além dessa organização formal dos conteúdos, ainda é ilustrativo da gestão do currículo o que ouvimos, por exemplo, na fala da professora Jan que, em agosto de 2015, mesmo com a participação ativa nos encontros de formação de março a julho, ainda não havia tido a ousadia de propor às crianças do segundo ano a adição com reserva. Isso foi revelado em um dos momentos de discussão em 14 de agosto. Junto com as colegas das outras turmas, Jan realizava o Jogo do Forme 10, mas na hora de sistematizar algumas operações e fazer a operação sobre a plataforma, ela 
sempre escolhia os números que, ao serem somados, não iriam gerar um agrupamento de $10 \mathrm{e}$ implicar em mudar da casa da unidade para a dezena.

Vimos em um momento do vídeo, gravado no encontro do dia 14 de agosto, após a avaliação inicial sobre o trabalho com o Jogo Forme 10, todas as professoras já tinham falado e iríamos vivenciar o Jogo do 2, mas fomos interrompidos porque a professora Jan ainda queria falar algo que a incomodava e, assim, iniciou uma fala meio relutante.

Professora Jan: Eu ainda estou meio devagar para trabalhar com reserva com eles... fico meio receosa... devido a alguns... não sei... eu tô evitando algumas situações que surgem a adição com reserva, mais eu ponho mais números que somados não geram a reserva... eu to vendo vocês aí e Eu estou... assim... com medo...

Pesquisadora: Se eles já estão indo...naturalmente ...Sou eu que estou com medo...Mais se eles já estão operando com as quantidades registradas do resultado do jogo...vamos exorcizar esse medo...

Professora Lu interrompe e diz: pois eu quero ir logo para centena....

Pesquisadora: Parte Lu eles vão entender. Veja na hora que eles chegarem no 90 mais 20 que dá 110, você vai dizer só semana que vem ou não que vem?

Professora Lu: Eu tinha muito medo de trabalhar com números grandes...nem tenho mais esse medo... pode falar cento e tanto...de limitar... esse medo eu não tenho mais...eles mostraram que dão conta de identificar um número maior que 100 ...registrar e fazer a representação.

Pesquisadora: Jan veja que essas trocas já estão acontecendo só não estão escritas...Você já pode segunda comece a escrever... quando eu chegar aqui na quinta você vai dizer já foi...Veja a diferença do dia 31 de julho para hoje, foi tranquilo ... é só você se soltar que vai acontecer...

Pesquisadora: agora então vamos relembrar que a multiplicação está acontecendo em situações em que temos, por exemplo, três de dez, que é três vezes de 10. Então vamos formalizar essa operação. O segundo ano ainda não vai para multiplicação... mas vamos aproveitar o tempo porque o terceiro ano está indo

Professora Lu: interrompe novamente e diz que o segundo não vai na próxima semana, mais vai na seguinte..

Pesquisadora: Isso mesmo e o trabalho do terceiro vai ajudar o segundo.

Professora Lu: não é assim termina um e começa o outro! ...é como você (Ana) falou, não é porque estamos entrando na multiplicação deixamos a adição.

Pesquisadora: Isso!!!

Começamos a estudar o Jogo do 2 para explorar a multiplicação...

Destacamos em negrito alguns trechos das falas que ocorreram no momento: "estou meio devagar para trabalhar com reserva"; "tô evitando algumas situações que surgem a adição com reserva"; "Eu tinha muito medo de trabalhar com números grandes"; "não é assim termina um e começa o outro!" "é como você (Ana) falou, não é porque estamos entrando na multiplicação deixamos a adição". Foram reveladas, nessas falas, as formas como os medos e as crenças arraigadas na formação das professoras implicam na organização curricular, interferem na seleção dos conteúdos a ensinar: o que será ensinado e o que será excluído.

Vimos que a professora Jan se sentiu à vontade para revelar o seu medo e esse foi superado pelo apoio do coletivo. Ao mesmo tempo, vimos que o medo de trabalhar com números grandes também foi suplantado e isso decorreu do entendimento da série cíclica, da forma como são compostos os números, da lógica que existe em sua escrita; isto é, a ampliação do conhecimento 
modificou a forma de definir os conteúdos que seriam ensinados. Além do mais, é importante ressaltar o entendimento de que os conteúdos não se encerram, mas se integram uns aos outros, pois eles contêm elos e devem ser revisitados o tempo todo. Nesse sentido, está presente a ideia de processo de constituição de um conceito, o que favorece a proposição de atividades de ensino que irão promover a mobilização dos conteúdos em diferentes situações, nas quais seja possível ir e voltar a determinados conteúdos, de modo a que estejam sempre presentes e sempre solicitados para não ficarem estanques.

Essa exigência na mudança de concepção, em que o coletivo se impunha ao individual (aspecto já tratado na seção 4.1), ocorria de modo aparentemente tranquilo, pois na escola já havia um trabalho sincronizado na elaboração de um plano de trabalho coletivo que, como vimos, na prática não acontecia tudo ao mesmo tempo em todas as salas, mas, de uma forma ideal, era o que se esperava. A revelação do ritmo diferenciado de trabalho foi importante para chamar a atenção do grupo, principalmente das coordenadoras, para se atentarem às individualidades e às lacunas conceituais existentes na formação de cada uma, que implicavam em seguir ou não o que estava previsto no plano de trabalho e mostravam o desenvolvimento do currículo. Assim, se colocava em suspense a segurança da afirmação: "esse conteúdo foi ensinado, veja que está no plano".

Vimos que essa questão revelou a imbricação entre as crenças, as concepções, as aprendizagens, a relação teoria e prática, que estão implicadas na organização curricular, na forma de avaliar e ler os resultados da avaliação, de organizar o trabalho pedagógico e de implementar uma ou outra prática em sala de aula. Essa pode ser analisada como uma evidência de como a gestação de uma nova aprendizagem é processual e de como essa nova aprendizagem provoca a adoção de uma nova postura. A delimitação do que será ou não ensinado implica diretamente na gestão do currículo. A aparente "liberdade" em implementar uma ou outra prática em sala de aula, pautava-se em uma visão de matemática escolar, seu ensino e sua aprendizagem e, também, em uma delimitação de conteúdos orientada algumas/muitas vezes pelas lacunas conceituais.

\subsection{A CONSTRUÇÃO DA AUTONOMIA INTELECTUAL: DA PRÁTICA A PRÁXIS}

Iniciamos a composição dessa subcategoria com uma inquietação que nos acompanhou o texto todo: seria essa uma supra categoria? Essa inquietação justificou-se pela percepção da relação entre vários aspectos do processo de pesquisa-formação: a problematização da prática, que foi tomada como objeto de análise pelo grupo, a produção de conhecimentos a partir das discussões dessa prática, as novas compreensões sobre o conceito de alfabetização e a busca por novos 
referenciais que implicou em criar tempo para leitura. Esse processo foi perpassado pela constituição da autonomia intelectual das alfabetizadoras e coordenadoras.

No grupo de discussão, em abril, momento inicial da pesquisa, quando uma das professoras afirmou que a aula não fazia sentido, a aula de matemática acontecia apenas no horário de matemática, era trabalhada por obrigação e não apoiada na certeza de este ser um direito da criança, ficamos preocupadas, mas animadas para trabalhar. Vemos que tanto o professor tem o direito de ver um sentido em sua ação de ensinar quanto a criança, como cidadã do mundo, tem o direito de aprender, pois a matemática faz parte dos conhecimentos construídos pelo homem, então deve estar a serviço do homem no sentido cognitivo, afetivo, social, ético, estético. (D’AMBRÓSIO,1990). Todas as crianças, no dia a dia, já convivem com a matemática em todos os seus aspectos. No processo de escolarização, elas devem ter oportunidade de constituir uma boa relação com a matemática da mesma forma como precisa ocorrer com todas as áreas do conhecimento.

O acompanhamento contínuo e permanente do processo de pesquisa-formação permitiu-nos ver que as professoras participavam de todo processo, estavam cada uma a caminho de constituir uma boa relação com a matemática. Isso implicava libertar-se das crenças e concepções equivocadas, deixar de sentir medo da matemática, inclusive de cometer erros e falar abertamente sobre suas dúvidas. Além disso, elas também deviam elaborar seus planos de trabalho de forma autônoma, o que não significa necessariamente fazê-lo de modo individual, mas desenvolver em sua sala a sequência pensada de modo adequado ao seu ritmo e ao de seus alunos, de forma coerente com os objetivos e não cerceada pelos medos ou pelas imposições externas.

Pautados nessas observações e na mesma direção das subcategorias anteriores, definimos quais as fontes das informações que seriam analisadas, neste trabalho, e retomamos as falas, os questionamentos, os materiais de referência dos encontros, os planos de trabalho, os depoimentos gravados durante o encontro literário e as aulas gravadas em vídeo. Assistir aos vídeos e rever as aulas nos deu uma visão do que significa autonomia e emancipação.

Como definimos no primeiro capítulo, retomamos aqui em uma versão simplificada do termo. Assim, autonomia significa "pensar com a própria cabeça" e emancipar-se de forma também simples seria "libertar-se de algo que o mantém preso". Desse modo, nossa lente de análise focou as aulas, pois na sala de aula os nossos conhecimentos produzidos em nossas discussões, estudos, problematizações, reflexões, planejamentos e avaliações se materializavam. 


\subsubsection{As aulas: espaço/ tempo de unificar teoria e prática}

Apresentamos, neste item, recortes de aula. Relembramos que nos encontros de discussão, os questionamentos eram realizados coletivamente, em alguns poucos encontros ficamos, as professoras de $2^{\circ}$ e de $3^{\circ}$ ano, em grupos separados. Pois o foco era a prática e, além de conhecer melhor o conteúdo, que era o mesmo no segundo e no terceiro ano, tínhamos que pensar em indicações gerais para a dinâmica da aula, de modo a torná-la mais coerente para a professora e mais produtiva para a criança.

Assim, por exemplo, a organização do trabalho pedagógico com a intencionalidade de explorar os conteúdos em situações problemas foi um consenso. A leitura da situação problema como um texto que deve ser aprendido pela criança também foi um entendimento coletivo. Houve dúvida em colocar ou não no plano as perguntas que poderiam ajudar no direcionamento de um diálogo entre professoras e crianças. Isso porque ajudaria as professoras a afastarem-se daquela postura de apresentar o problema e logo resolvê-lo pela criança. Cientes de que a prática que era desenvolvida provocava a pergunta: "que conta é?", discutimos sobre isso e mudamos os nossos planos de trabalho. As produções das crianças e das professoras foram analisadas de modo mais detalhado na primeira categoria, apresentada no terceiro capítulo. Interessa-nos, aqui, a sequência das aulas decorrentes desta tentativa de mudança no modo de explorar o conteúdo, que implicou em mudança na prática por elas desenvolvida.

As aulas do $2^{\circ}$ ano eram sobre o Sistema Monetário Brasileiro e, do mesmo modo como nas turmas do $3^{\circ}$ ano, estávamos tentando problematizar os problemas e elaborar perguntas para estabelecer um diálogo com as crianças, como já relatamos no capítulo 3. Esse conteúdo aparentemente não tinha nenhum aspecto dificultador, até mesmo as trocas exigidas no Jogo Forme 10 favoreciam a visualização das trocas de moedas de menor valor por moedas de maior valor ou por cédulas. Estavam previstas como tarefas a exploração do paradidático e do livro didático.

Na turma da professora Dan, acompanhamos como observadoras, as aulas em que o livro didático foi utilizado como recurso base. No vídeo, vemos todas as crianças com o livro aberto e a professora orientando como deveria ser realizada a leitura. As perguntas possíveis foram registradas no plano de trabalho que era consultado o tempo todo pela professora.

O falar compassado, instruir, orientar de forma calma, dar tempo a todos de localizar a informação na página do livro era algo específico da ação de alfabetizar. A todo momento considera-se que o que para nós é trivial, para as crianças é algo novo. No recorte do plano de trabalho previsto para duas semanas é possível ver o detalhamento das perguntas. 
No momento em que conseguimos colocar no plano de trabalho nossa intencionalidade, inclusive com uma proposta de dialogar com as acrianças e explorar ao máximo os conteúdos a ensinar, avaliamos que estávamos bem próximas de uma postura autônoma em relação à especificidade de nossa profissão. As indicações de perguntas, como já exposto no capítulo 3, não representam um caminho único e nem haveria necessidade de segui-las. Um recorte do plano de trabalho com o paradidático Economia de Maria consideramos como ilustrativo da tentativa de adotar o diálogo em suas aulas. Ressaltamos que as perguntas foram colocadas apenas como uma forma de orientar o nosso diálogo, pois ainda não estávamos familiarizadas com esse modo de fazer a aula. As aulas de matemática, lembramos, eram desprovidas de sentido, sem convite à participação das crianças e o enunciado de um problema não era visto como texto. Equacionar todos esses aspectos e, ao mesmo tempo, ter flexibilidade de pensamento e buscar outros conhecimentos consideramos como indicativo de busca de autonomia.

Figura 52 - Sequência didática para o segundo ano

\section{TERÇA-FEIRA 15/09/2015}

\section{* $\quad 2^{\circ}$ Momento: Matemática}

$\checkmark$ Relembrar a história "A economia de Maria" para introduzir o assunto sobre o sistema monetário brasileiro, questionar:

- O que Helena e Maria ganharam? - Para que serve um cofre?

- Que tipo de dinheiro as meninas colocaram no cofre? - Como se chama o nosso dinheiro?

- De quais formas podemos encontrar o nosso dinheiro?

- Explicar que a moeda brasileira se chama Real e que cada país tem sua própria moeda e cada uma um nome especifico, exemplo: a moeda dos EUA é o Dólar, do Japão é o Yen, da Alemanha é o Euro, da Argentina é o Peso argentino.

$\checkmark$ Apresentar modelos das cédulas e moedas explicando que cada uma tem um valor, marcas especificas para evitar a falsificação e estampada em cada uma um animal diferente da fauna brasileira.

$\checkmark \quad$ Distribuir entre os alunos várias cédulas e moedas de valores diferentes (este material poderá ser destacado do caderno de encarte dos jogos do PNAIC).

$\checkmark \quad$ Lançar desafios envolvendo a multiplicação, a adição, a subtração, dobro e triplo para os alunos resolverem utilizando o "dinheirinho", exemplos:

- Qual é a cédula de maior valor e a moeda de maior valor no nosso sistema monetário? E as de menor valor? - Se pegar uma nota de 10 reais e uma de 5 reais, quantos reais teremos?

- Se pegar uma nota de 50 reais e uma nota de 20 reais, quantos reais teremos? teremos?

- Se pegar uma nota de 20 reais, uma de 5 reais e uma moeda de 1 real, quanto teremos?

- Se pegar uma nota de 100, uma de 50 reais e uma de 2 reais, quantos reais

- Se você for comprar um pacote de biscoito que custa 3 reais e der 10 reais para pagar, quantos reais você irá receber de troco?- Se pegar três vezes uma nota de 5 reais com quanto vai ficar?

- Se pegar seis vezes uma nota de 2 reais com quanto vai ficar?

- João tem 8 reais e Vitor tem o dobro. Quantos reais Vitor tem?- Marta tem 6 e Rita tem o triplo desse valor. Quantos reais Rita tem? - Ricardo tem 100 reais e José tem a metade desse valor. Quantos reais José tem? - Eu preciso de 8 reais, que cédulas ou moedas eu poderei pegar para obter esse valor? Existem outras possibilidades? 
No vídeo, vemos a tentativa de fazer diferente e ao mesmo tempo que era realizado a exploração do paradidático Economia de Maria, utilizava-se o livro didático em que as leituras eram mais detalhadas e mais adequadas ao processo de alfabetização em que se encontravam as crianças. Lembramos que essa professora é a mesma que em abril disse que trabalhava matemática escolar porque era obrigada a fazê-lo, mas não via sentido em seu trabalho com essa disciplina.

Quadro 5 - Descrição da aula realizada no segundo ano

\begin{tabular}{|c|c|}
\hline Dimensão visual & Dimensão verbal \\
\hline $\begin{array}{l}\text { Professora a frente } \\
\text { Sobre a mesa o plano de } \\
\text { trabalho para o dia } 16 \text { de } \\
\text { setembro }\end{array}$ & $\begin{array}{l}\text { Professora: Olhem o livro...observem as cédulas. } \\
\text { Professora: Qual o valor da primeira cédula } \\
\text { Crianças: O valor é } 2 \text { reais } \\
\text { Professora: E a segunda cédula } \\
\text { Crianças: Cinco reais } \\
\text { Professora: A terceira cédula } \\
\text { Crianças: Dez reais } \\
\text {......... } \\
\text { Professora: Vocês perceberam que cada cédula tem um valor...certo.. } \\
\text { Professora: Os valores são iguais? } \\
\text { Crianças: São uns maiores dos que os outros } \\
\text { Professora: Tem o mesmo valor } \\
\text { Todos; Não.. } \\
\text { Professora: Tem valores... } \\
\text { Crianças: Diferentes }\end{array}$ \\
\hline
\end{tabular}

Fonte: Arquivo da pesquisadora, 2015.

Compassadamente, as crianças são convidadas a acompanhar a leitura. Assim, a partir desse modo de propor a atividade, reiteramos que podemos identificar um forte indício do respeito ao processo de alfabetização, ao considerar a aproximação da criança com a leitura, a escrita, a apropriação da linguagem matemática e a necessária mobilização dos conceitos que estavam sendo aprendidos. Na sequência, foi realizada a continuação da leitura do livro didático de matemática. 
Quadro 6 - Continuação das atividades com o segundo ano

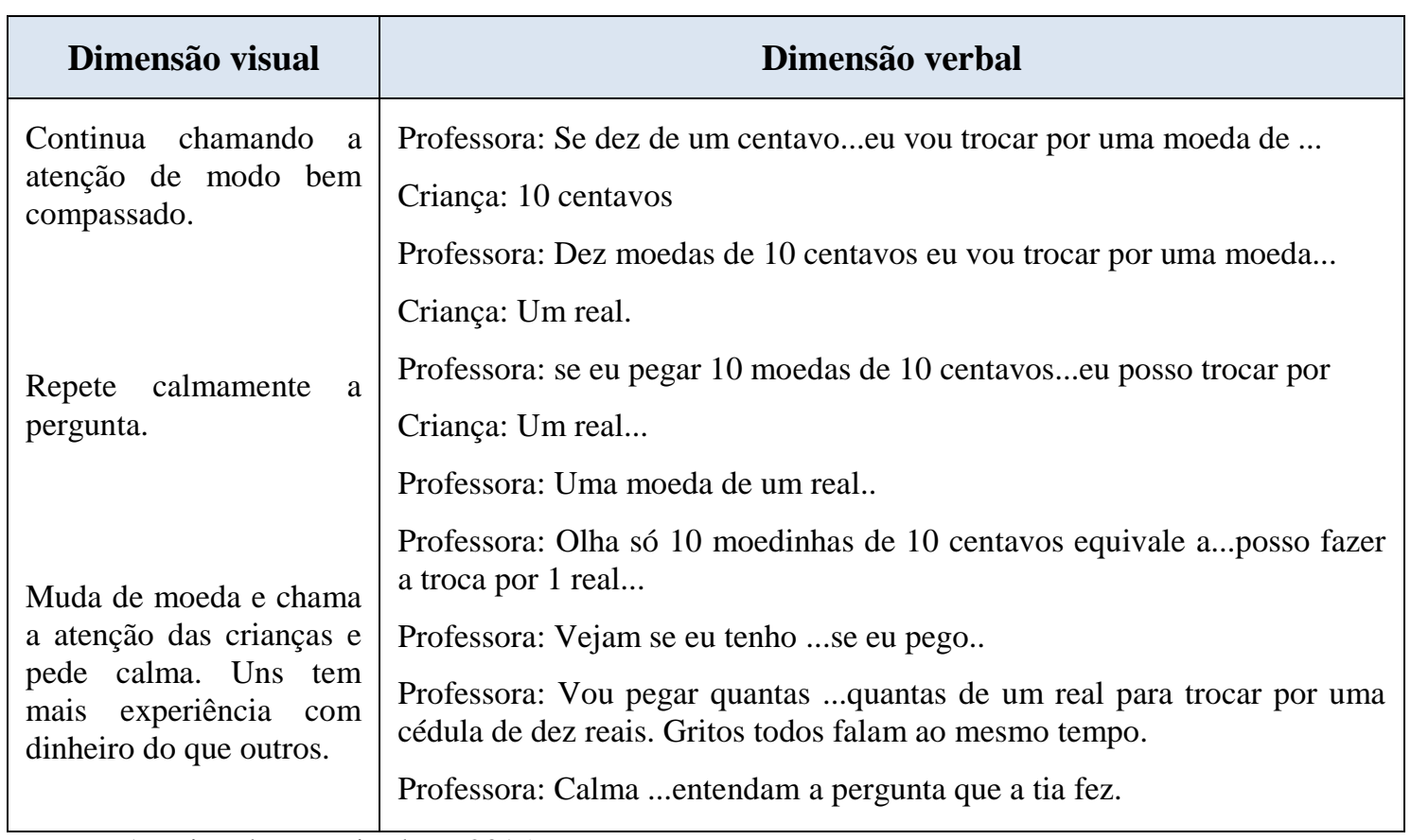

Fonte: Arquivo da pesquisadora, 2015.

As perguntas orais convidavam a formular "na cabeça" uma resposta, consideramos que por meio delas a professora os instigava a pensar.

Quadro 7 - Descrição da aula no segundo ano - continuação

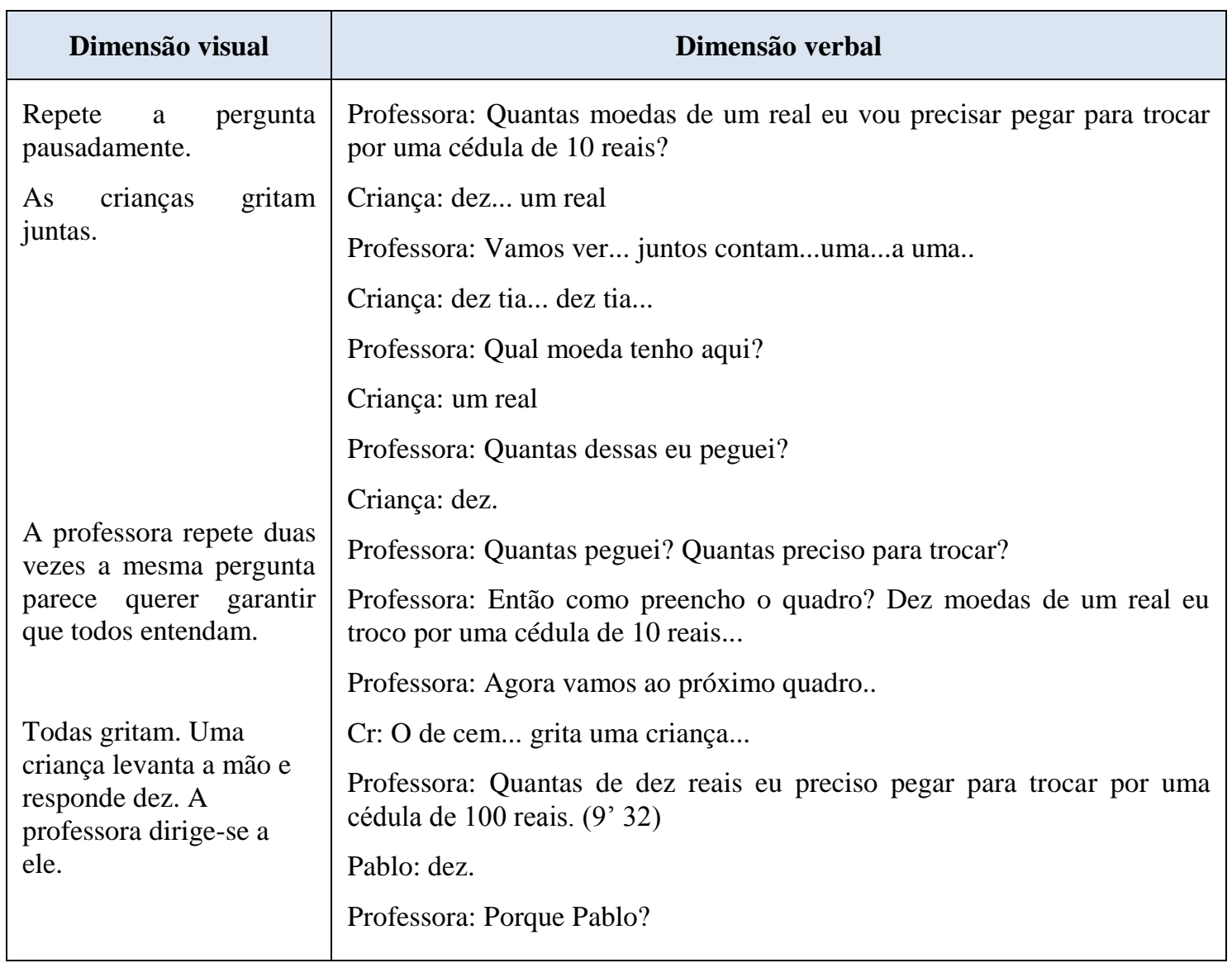


Vimos acima uma criança que grita e responde rapidamente a pergunta: quantas de dez reais eu preciso pegar para trocar por uma cédula de 100 reais? A professora mostrou-se atenta a fala da criança e pede que ele explicite o que pensou como se vê na sequência da transcrição do vídeo.

Quadro 8 - Continuação das atividades com o segundo ano

\begin{tabular}{|l|l|}
\hline \multicolumn{1}{|c|}{ Dimensão visual } & \multicolumn{1}{c|}{ Dimensão verbal } \\
\hline $\begin{array}{l}\text { Pablo mostra as mãos e } \\
\text { gesticula do tempo todo. }\end{array}$ & $\begin{array}{l}\text { Criança: Por que se nos juntar dez...temos dez, vinte trinta e contar dez } \\
\text { vezes o dez, dez mais dez vinte, mais dez, trinta, mais dez, 40, mais dez, } \\
50, \text { mais dez, 60, mais dez, 70, mais dez, 80, mais dez, 90, mais dez,100... } \\
\text { fica cem... } \\
\text { Criança: Assim As mãos dez em dez. Dez dedos. Fica cem } \\
\text { Professora } \\
\text { admiração } \\
\text { mostra } \\
\text { dez... até chegar ao valor... ou seja ele contou dez vezes da nota de .... } \\
\text { Criança: Dez... } \\
\text { Professora: e então encontrou } 100 .\end{array}$ \\
\hline
\end{tabular}

Fonte: Arquivo da pesquisadora, 2015.

E a aula continuou sempre com o diálogo com as crianças e a exploração do problema proposto no livro didático. Ressaltamos a disponibilidade em ouvir a explicação da criança, inclusive convidando os colegas a prestar atenção. No encontro de discussão esse momento da aula foi comentado, inclusive com destaque a questão do modo como a criança explicitou o seu pensamento. E, uma dúvida era como explorar mais esses momentos de fala da criança. Ao observamos esse fato houve um entendimento no grupo de que era urgente reivindicar tempo para estudar e melhor compreender o processo de aprendizagem.

Apresentamos a seguir a aula da professora Ira, do $2^{\circ}$ ano. Observamos uma tranquilidade na gestão da aula, em que a professora criou, junto com as crianças, um problema com também com o contexto da história infantil apresentada no livro paradidático A Economia de Maria. A situação já foi apresentada no capítulo 3.

Quadro 9 - Descrição da aula do segundo ano profa. Ira

\begin{tabular}{|l|l|}
\hline \multicolumn{1}{|c|}{ Dimensão visual } & \multicolumn{1}{|c|}{ Dimensão verbal } \\
\hline $\begin{array}{l}\text { Crianças com os cadernos em mãos. Na folha do } \\
\text { caderno está colada a situação criada por eles na } \\
\text { aula anterior. }\end{array}$ & $\begin{array}{l}\text { Professora: Por favor, façam a leitura da } \\
\text { historinha que nós criamos. } \\
\text { Inicia... para e pede que todos leiam juntos. } \\
\text { Crianças leem em voz alta. } \\
\text { Professora escreve a informação no quadro } \\
\text { Professora: Certo dia duas meninas resolveram ir } \\
\text { ao... }\end{array}$ \\
& $\begin{array}{l}\text { Professora: Quem comprou o lápis de um real.. } \\
\text { Criança: Mariana } \\
\text { Professora: Vamos continuar... Quer dizer as duas } \\
\text { juntas são dez reais? } \\
\text { Criança: Não.. }\end{array}$ \\
\hline
\end{tabular}




\begin{tabular}{|l|l|}
\hline \multirow{5}{*}{ Professora reafirma } & Professora: Como é? \\
& Professora: Dá vinte porque cada uma custava? \\
& Criança: Dez reais \\
& Professora: Sombrinha e bolsa...dez reais cada... \\
& Continuem \\
& Professora: E agora? Além da sobrinha e da bolsa \\
o que compraram? \\
Criança: Um ioiô \\
Professora: E quanto custava o ioiô? \\
Criança: Cinco reais. \\
& Professora: Qual o valor das mercadorias de \\
& Júlia? \\
& Professora: Primeiro o que queremos saber? O \\
que está perguntando primeiro? \\
\\
Criança: é 25... não é 26.
\end{tabular}

Fonte: Arquivo da pesquisadora, 2015.

As informações eram dadas pela criança e registradas no quadro pela professora.

Quadro 10 - Continuação da aula do segundo ano - profa. Ira

\begin{tabular}{|c|c|}
\hline Dimensão visual & Dimensão verbal \\
\hline \multirow{2}{*}{$\begin{array}{l}\text { Recomeça... Anda pela } \\
\text { sala e chama a atenção da } \\
\text { turma. }\end{array}$} & Professora: Qual a primeira perguntinha que tem aqui? \\
\hline & Criança: Qual o valor da mercadoria de Júlia? \\
\hline \multirow{6}{*}{$\begin{array}{l}\text { Professora repete } \\
\text { calmamente a pergunta. } \\
\text { Continua a fazer perguntas } \\
\text { para explorar a situação e } \\
\text { envolver as crianças na } \\
\text { estratégia de solução. }\end{array}$} & Professora: O que foi que Júlia comprou? \\
\hline & Criança: Uma sombrinha .. \\
\hline & Professora: Uma sombrinha ...que custava quanto \\
\hline & Criança: Dez reais. \\
\hline & Professora: Uma bolsa que custava quanto? \\
\hline & Criança: Dez reais. \\
\hline \multirow{13}{*}{$\begin{array}{l}\text { As crianças não mostram } \\
\text { dificuldades e muitas já } \\
\text { escreveram a operação que } \\
\text { resolve o problema. }\end{array}$} & Professora: E mais o que? \\
\hline & Criança: Um ioiô. \\
\hline & Professora: Isso um ioiô ...que custava quanto? \\
\hline & Criança: Cinco reais. \\
\hline & Professora: Qual o valor da Julia? \\
\hline & Criança: Vinte e cinco. \\
\hline & Professora: E como vocês fizeram para achar esse valor? \\
\hline & Criança: Juntando. \\
\hline & Professora: Juntando o que? \\
\hline & Criança: 10 mais 10 mais $10 \ldots$ \\
\hline & $\begin{array}{l}\text { Professora: e aqui (mostra o registro no quadro) as duas custavam } 10 \text { ou } \\
\text { era cada uma. }\end{array}$ \\
\hline & Criança: Cada uma \\
\hline & Professora: Interessante é isso ...Cada uma custava então pegaram como? \\
\hline
\end{tabular}


Em alguns momentos convida as crianças para irem ao quadro registrar o seu jeito de representar. Isso pode ser considerado uma evidencia de mudança no olhar para a criança como produtora de conhecimentos, pois essa é chamada ao quadro, não para ter seus conhecimentos testados e sim para explicitar seu pensamento.

Quadro 11 - Criança é convidada a registrar no quadro

\begin{tabular}{|c|c|}
\hline Dimensão visual & Dimensão verbal \\
\hline $\begin{array}{l}\text { Professora chama ao } \\
\text { quadro uma das } \\
\text { meninas para mostra a } \\
\text { turma o que escreveu. }\end{array}$ & $\begin{array}{l}\text { Professora: Samara vem aqui registrar como você fez? } \\
\text { Criança faz o registro : } 10+10+5 \text {. } \\
\text { Professora: muito bem Samara...obrigada } \\
\text { Professora: Gente esse foi o jeito que ela achou de registrar...explica para } \\
\text { nós Samara... a resposta está certa? Como você achou? } \\
\text { Professora: Esse dez é de que } \\
\text { Criança: da bolsa } \\
\text { Professora: esse outro dez é } \\
\text { Criança: da sombrinha } \\
\text { Professora: e esse cinco? } \\
\text { Criança: do ioiô } \\
\text { Professora: qual a operação ela usou? } \\
\text { Todos: do mais... } \\
\text { Professora: que é adição? qual o sinal do mais? } \\
\text { Professora: quem quer fazer a outra pergunta (Samara diz que tem outra } \\
\text { forma) }\end{array}$ \\
\hline
\end{tabular}

Fonte: Arquivo da pesquisadora, 2015.

$\mathrm{Na}$ sequência vimos que as crianças afirmam ter outro modo de fazer e ao serem questionadas explicam que podem usar a multiplicação para representar o duas vezes dez reais. Vimos no registro escrito, apresentado no quadro a seguir, que ainda seria necessário estudar sobre o modo como foi representado e que um registro mais adequado seria 2 x 10 e não 10 x 2. Mas no encaminhamento do processo de pesquisa - formação tínhamos cada vez mais clareza de nossas necessidades quanto aos estudos que ainda seriam realizados.

Quadro 12 - Registro dos diálogos entre professora e crianças

\begin{tabular}{|l|l|}
\hline \multicolumn{1}{|c|}{ Dimensão visual } & \multicolumn{1}{c|}{ Dimensão verbal } \\
\hline $\begin{array}{l}\text { Professora } \\
\text { convida-os a } \\
\text { pensar em outra } \\
\text { forma. }\end{array}$ & $\begin{array}{l}\text { Professora: a Samara diz que tem outra forma de fazer essa aqui } \\
\text { Professora: ela disse que consegue fazer pela multiplicação } \\
\text { Professora: como é? } \\
\text { Criança: } 10 \text { xis } 2 \\
\text { Professora: } 10 \times 2 \\
\text { Professora: Ah o mariano falou... } 10 \times 2=20 \\
\text { Professora: Porque é 2?... }\end{array}$ \\
\hline
\end{tabular}




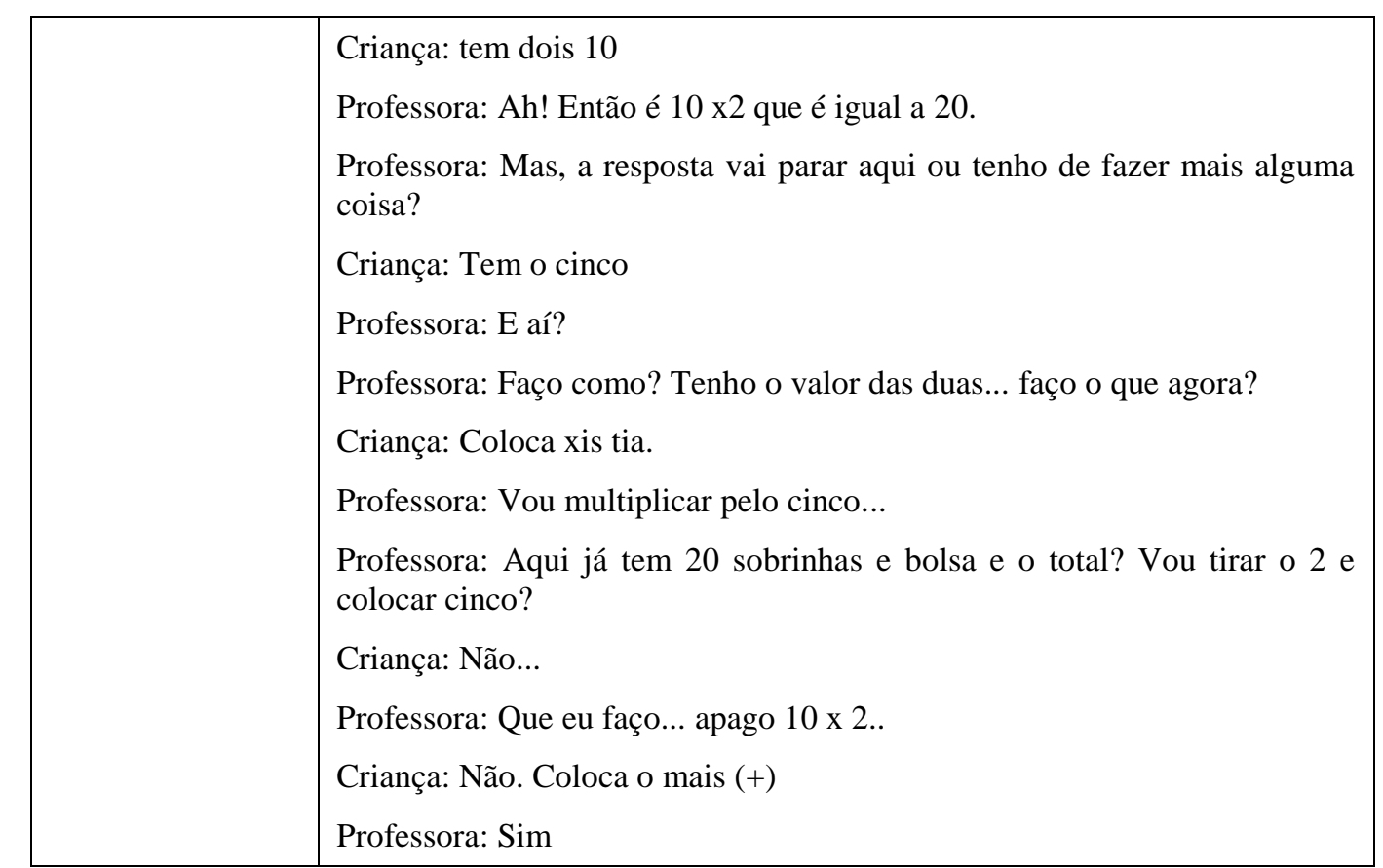

Fonte: Arquivo da pesquisadora, 2015.

Se pensarmos que as operações se resumiam ao "arme e efetue" e que a resolução de problemas era realizada pela criança, mas para isso a professora direcionava todo o processo e já dizia a resposta e na entonação de voz destacava termos que eram automatizados pelas crianças sem nenhuma compreensão, essa forma de tentar envolver as crianças na resolução, provocá-las, instigálas e fazê-las pensar em como resolveram é algo aparentemente simples, porém, face aos estudos que conhecemos sobre algumas práticas ainda vigentes pode ser considerado uma grande evolução.

Quadro 13 - A professora convida a criança a expor o seu pensamento

\begin{tabular}{|c|c|}
\hline Dimensão visual & Dimensão verbal \\
\hline $\begin{array}{l}\text { Começa a r chamar } \\
\text { atenção aos } \text { modos } \\
\text { diferentes de resolver. }\end{array}$ & $\begin{array}{l}\text { Professora: Posso colocar } 20+5 \text { o resultado está diferente? O que está } \\
\text { diferente? É a forma de resolver? } \\
\text { Criança: Isso... }\end{array}$ \\
\hline $\begin{array}{l}\text { Professora aponta para } \\
\text { o registro no quadro } \\
\text { para as formas de } \\
\text { resolver. }\end{array}$ & $\begin{array}{l}\text { Professora: Na primeira usou o mais. Na segunda usou o que? } \\
\text { Criança: a multiplicação } \\
\text { Professora: Na segunda só a multiplicação? } \\
\text { Criança: Não } \\
\text { Professora: usou a multiplicação e a adição. O resultado foi o mesmo? } \\
\text { Criança: Foi } \\
\text { Professora: Está errada alguma? } \\
\text { Criança: Não } \\
\text { Professora: Então todas estão certas são estratégias diferentes que você usa }\end{array}$ \\
\hline
\end{tabular}




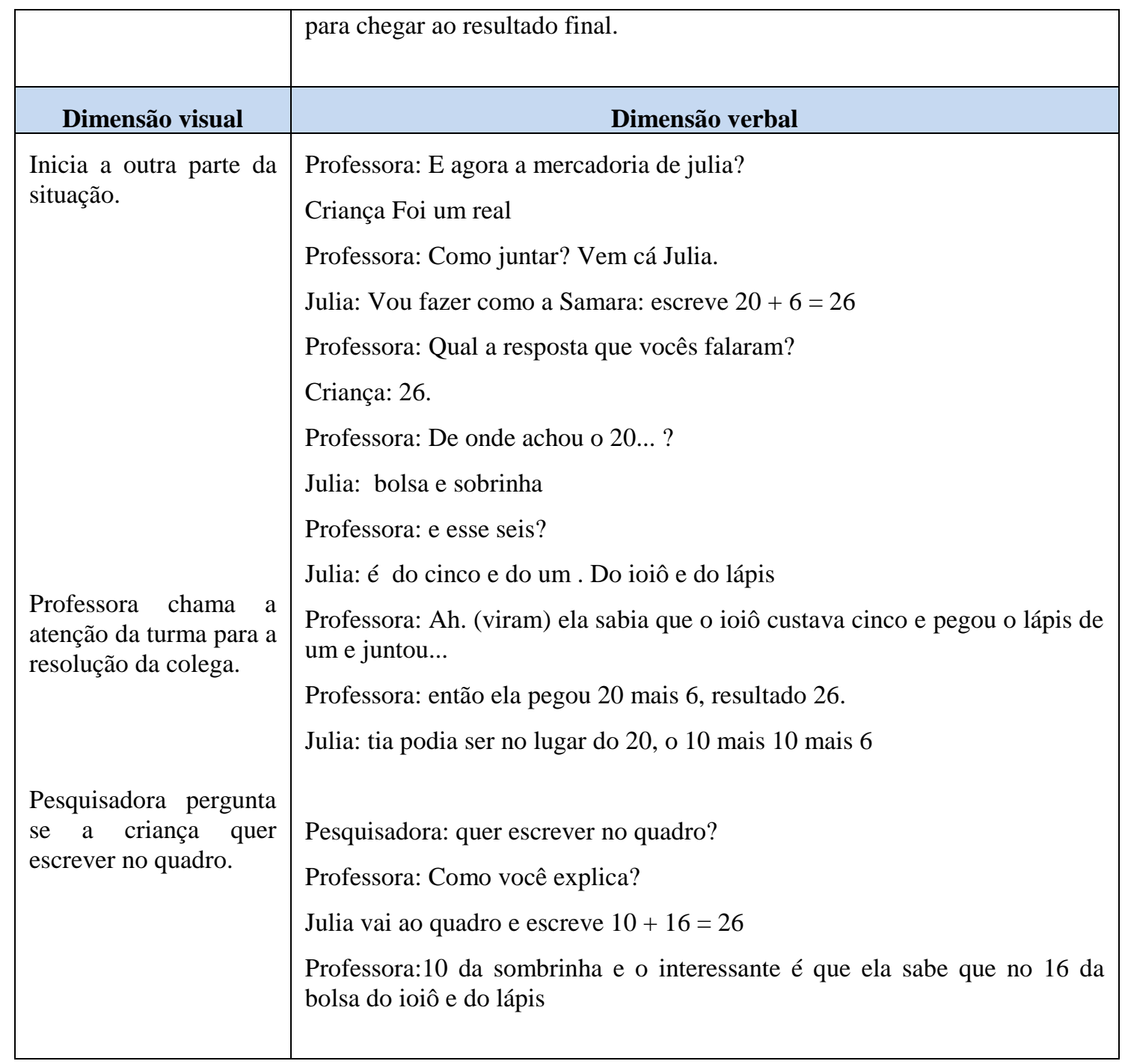

Fonte: Arquivo da pesquisadora, 2015.

Observamos que a professora está imbuída da ideia de metacognição ${ }^{34}$ e mostra querer que a criança exponha sua forma de pensar.

Quadro 14 - A professora continua a instigar as crianças

\begin{tabular}{|c|l|}
\hline \multicolumn{1}{|c|}{ Dimensão visual } & \multicolumn{1}{c|}{ Dimensão verbal } \\
\hline $\begin{array}{l}\text { Professora convida a criança a } \\
\text { ir ao quadro e expor seu modo } \\
\text { de pensar. }\end{array}$ & $\begin{array}{l}\text { Professora: Guilherme mostra para nós como você fez. } \\
\text { Professora: vamos ouvir como }\end{array}$ \\
& Professora: Como achou o 15? \\
$\begin{array}{l}\text { Professora chama outra } \\
\text { criança ao quadro, pois viu }\end{array}$ & $\begin{array}{l}\text { Guilherme: Contei nos dedos o 15. Como quem é o 15 } \\
\text { Professora: Contou o 10 e o 5. Isso. Todos compreenderam? }\end{array}$ \\
\hline
\end{tabular}

34 Mais adiante, neste texto, ao discutirmos sobre a leitura na formação do professor, transcrevemos uma entrevista dessa professora em que ela destaca a leitura do texto de Carvalho e Lima (2010), no livro da Coleção Explorando o Ensino em que o autor falou sobre a metacognição. 
como ele fez diferente. Chama Guilherme que fez $10+15=$ 25

Fonte: Arquivo da pesquisadora, 2015.
Ok...gente...

Observamos que foram considerados os modos diferentes adotados pelas crianças. Em muitas salas de aula ainda é possível ver uma aula de matemática em que a criança permanece calada sem participar e sem compreender. Assim, o desejo de entender o que a criança pensa convidando-a a se expressar é uma grande mudança. Após a aula, pedimos a professora para falar sobre a aula e ela mostrou um dos cadernos e disse:

"Essa criança tinha dificuldades em operar. Nessa situação, além de operar com o material de apoio, escreveu os números e os sinais correspondentes. [A professora se mostrou admirada], Ao responder a segunda pergunta ele junta $5+1$ e faz 6 e escreve $10+10+6=$ 26.” (Diário de campo. Setembro de 2015. Arquivo da pesquisadora)

Ao avaliar as produções, mostrou-se interessada nas diferentes formas de registro adotadas pelas crianças.

Figura 53 - Registro das operações

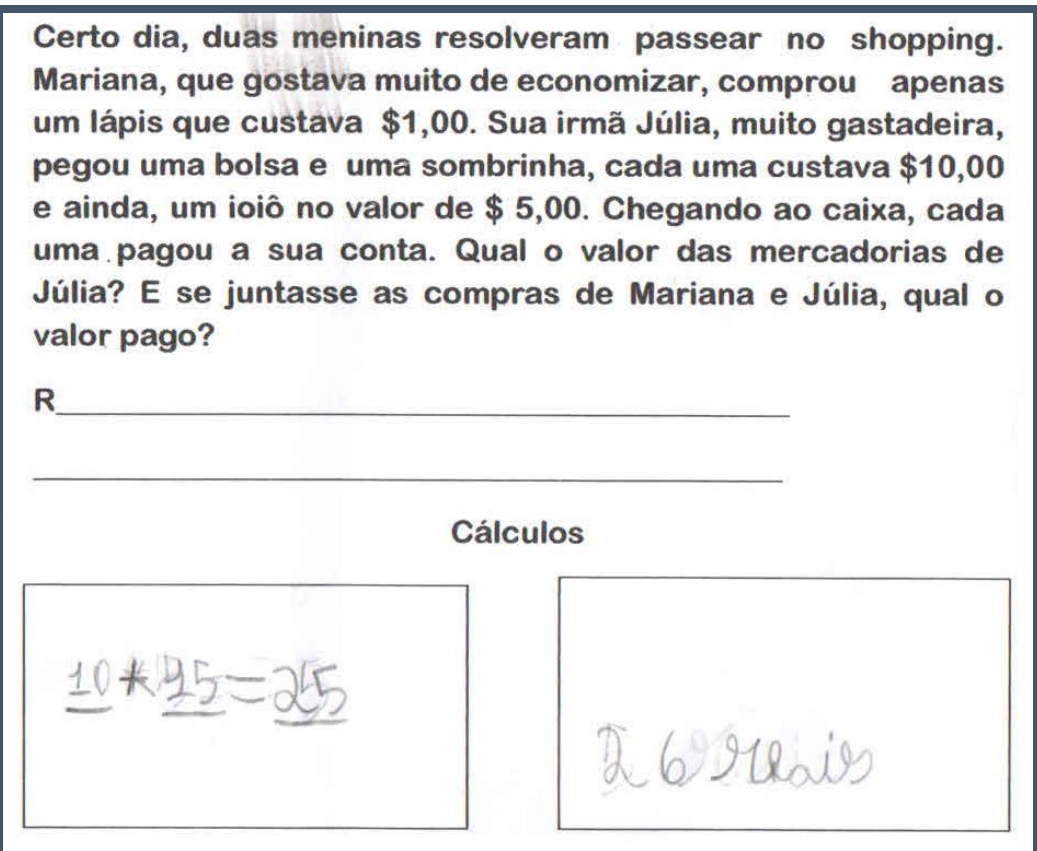

Fonte: Arquivo da pesquisadora, 2015.

Um deles, apresentado na figura 53 , escreve no primeiro no primeiro quadro $10+15=25$, que é a resposta para a primeira pergunta; no segundo quadro, essa mesma criança escreve direto 26 
(resultante de $25+1)$. A outra criança, conforme figura 71 , escreve $(10+10+5=25$, escreve o valor das sombrinhas separadamente, cada uma custa 10 reais) e, no segundo quadro, escreve toda a operação da primeira pergunta e soma mais $1(10+10+5+1=26)$. É possível inferir que a produção cognitiva é alicerçada em quatro fortes pilares: interpretação - produção de procedimentos - produção de registros - validação apoiada nos registros e na argumentação oral.

Figura 54 - Registro da segunda criança

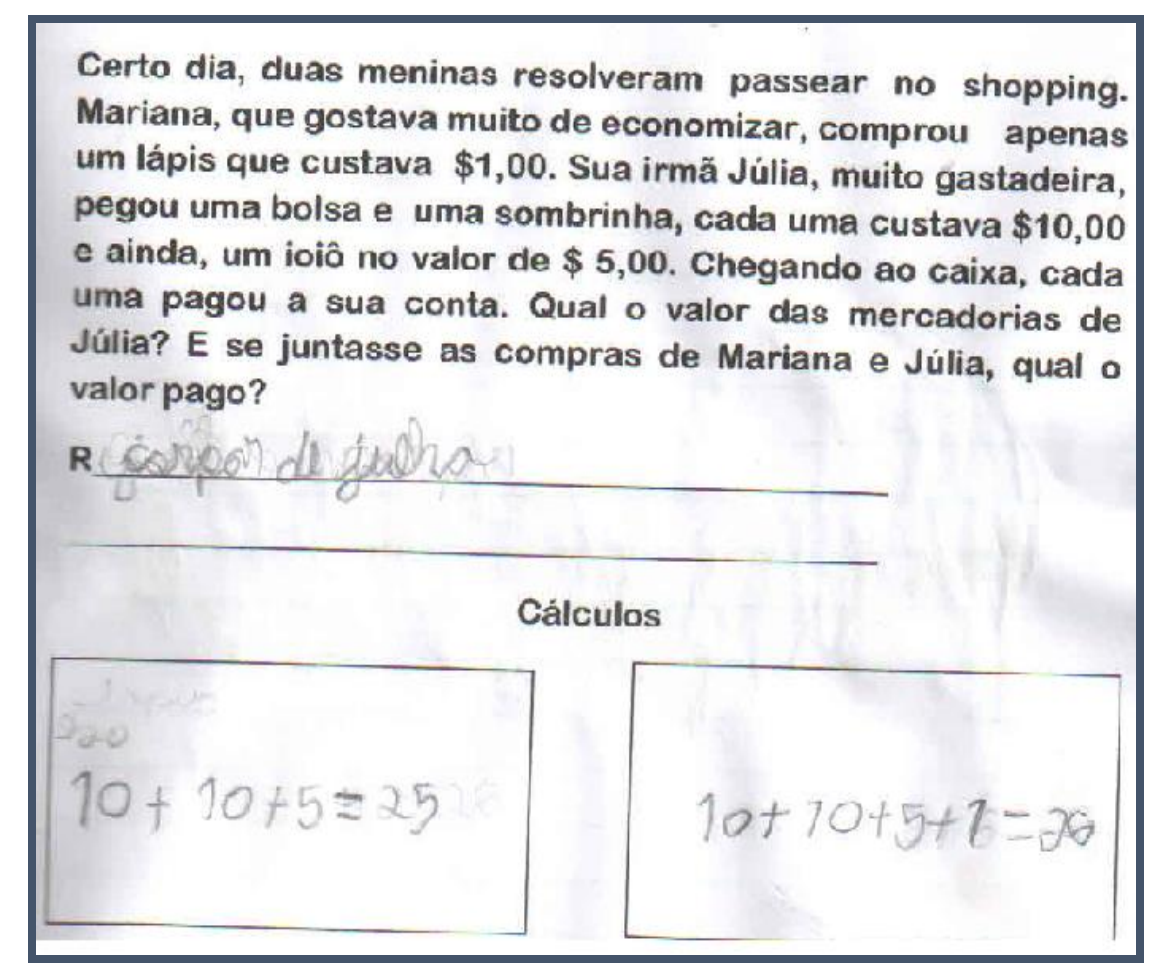

Fonte: Arquivo da pesquisadora, 2015.

Essa percepção das formas diferentes de registro adotadas pelas crianças deu à professora um ânimo em pensar melhor sobre o processo de aprendizagem. Ela pôde refletir sobre a questão de pensar que aquilo que é dito seja compreendido de maneira uniforme por todas as crianças. A partir dessa situação, apoiados em Nacarato (2014), podemos afirmar que há uma aprendizagem de apropriação do texto matemático, em que a produção de registros na forma aritmética revela-se um desafio para a criança. Essa escrita pode ser também considerada como um gênero textual pleno de significados, que se constituem apoiados em signos próprios do campo de conhecimento matemático, os quais a criança está em processo de assimilação e de produção de significado e sentidos. Esses signos são objetos de análises semióticas. Esse é um rico campo de estudos que poderemos seguir futuramente na continuidade da pesquisa com o grupo de professoras. 
Ao analisar as informações até o momento - os planos de trabalho, as discussões coletivas, o desenvolvimento das aulas- consideramos essas como indicadoras do caminho de uma práxis reiterativa à uma práxis criadora e, à medida que, a base de conhecimentos foi ampliada e uma autonomia intelectual se configura essa práxis começa a revelar-se emancipatória.

Ainda entendemos que um momento importante na pesquisa - formação, que evidenciou a autonomia e a emancipação foi o encontro literário, com todas as decisões individuais que foram necessárias para que esse momento coletivo pudesse acontecer. Foi exigido do grupo que fizessem um deslocamento no tempo dedicado a outras atividades pessoais e profissionais para criar um tempo de leitura. Isso foi um fato marcante em nosso trabalho.

Vamos discutir, nesta próxima seção, o embrião de um trabalho de incentivo à leitura e de criação de um espaço de socialização dos conhecimentos que nos chegam por meio da leitura de textos acadêmicos. Textos que deveriam ter sido lidos na academia, durante o curso de formação inicial, mas as então estudantes e, atualmente, professoras, nem sempre tiveram oportunidade e tempo para desenvolver essa atividade que é inerente à profissão professora.

\subsubsection{A leitura na formação das professoras: um encontro literário em educação matemática}

Desde os primeiros meses de inserção no campo de pesquisa, convidamos as professoras a se aproximarem dos livros da área de educação matemática. Inicialmente com os livros do acervo pessoal da pesquisadora e com os cadernos dos programas Gestar I, Pró-Letramento e PNAIC, programas conhecidos pelas professoras e disponíveis na escola. A medida que a aproximação pesquisadora - professoras - coordenadoras se intensificava, passamos a frequentar a sala de leitura e, enfim, catalogamos os livros que chegam à escola por meio do PNBE - Biblioteca do Professor. Os livros sempre estiveram lá, na sala de leitura, mas ainda não tinham despertado a curiosidade das professoras. Quando comecei a citar autores e a emprestar os meus livros (desde o mês de abril) a coordenadora falou dos livros que a escola recebe e queixou-se do esforço que fez no ano passado para que a equipe fizesse a leitura de um livro sobre resolução de problemas.

Os títulos disponíveis, na sala de leitura da escola ${ }^{35}$, para a área de educação matemática, estão dispostos no quadro abaixo:

\footnotetext{
${ }^{35}$ A escola funciona em um prédio alugado em que o $1^{\circ}$ andar é residência e no térreo estão as dependências da escola. A equipe da escola, ao participar de programas realizados pelo MEC, como o Mais Educação, gerenciou adequadamente os recursos e criou um aspecto de prédio escolar.
} 
Quadro 15 - Acervo sobre educação matemática pertencente à escola

\begin{tabular}{|c|c|c|}
\hline Quantidade & Título & Autor \\
\hline 02 & Quatro operações básicas. & Katia Stocco Smole. \\
\hline 02 & Figuras Planas. & Katia Stocco Smole. \\
\hline 01 & Sistema de Numeração decimal. & Katia Stocco Smole. \\
\hline 02 & Explorando o ensino da matemática. & Ministério da Educação. \\
\hline 01 & $\begin{array}{l}\text { A matemática nos anos iniciais nos anos } \\
\text { fundamentais. }\end{array}$ & Adair Mendes Nacarato. \\
\hline 01 & $\begin{array}{l}\text { Desenvolvimento de competências } \\
\text { matemáticas. }\end{array}$ & Àngel Alsina I Pastells. \\
\hline 01 & Teoria e pratica de matemática. & Marilia Toledo. \\
\hline 01 & $\begin{array}{l}\text { Formulação e resolução de problemas de } \\
\text { matemática. }\end{array}$ & Luiz Roberto Dante. \\
\hline 01 & $\begin{array}{l}\text { Cadernos de mathema (Jogos de } \\
\text { matemática } 1^{\circ} \text { ao } 5^{\circ} \text { ano.) }\end{array}$ & Katia Stocco Smole. \\
\hline 01 & Educação matemática. & Terezinha Nunes. \\
\hline 01 & Desenvolvimento matemático na criança. & Barbara M. Brizuela. \\
\hline
\end{tabular}

Fonte: Arquivo da pesquisadora, 2015.

Observamos que a produção de conhecimentos, realizada pelas professoras, voltava-se exclusivamente para a prática rotineira da sala de aula. Vimos a necessidade de tomar essa prática como objeto de análise e de confrontá-la com estudos teóricos que provocassem a reflexão e a problematização da prática. A indefinição de um espaço institucional de estudo, com carga horária incluída na carga horária semanal tornava tudo mais difícil. Assim, não havia uma exigência formal para que as professoras estudassem, mas as leituras de referência eram indicadas por nós a cada vez que uma demanda surgia.

E, ao concordar com Santos (2010) quando afirma que a prática pedagógica, enquanto trabalho humano, "é uma atividade teórico-prática" (p.70), insistimos em criar tempo para estudar a nossa prática em alfabetização matemática e estudar os resultados de pesquisa analisados por especialistas em educação matemática. Por mais resistência que essa ideia possa ter causado, um paradoxo foi instalado: a profissão professor, do mesmo modo como todas as outras profissões que exigem do profissional uma atividade intelectual mais sistemática, traz implícita o tempo para leitura e para alimentação dos conhecimentos. Então, a leitura não é uma imposição e, sim, uma das muitas atividades inerentes a nossa profissão - professora. Sendo assim, por que resistimos a leitura? Nossa identidade profissional está deformada? Com qual profissional nos identificamos? Qual o tempo institucional o professor tem para dedicar-se a leitura? 
Nossa experiência profissional, enquanto formadora de professoras, nos fazia ver a imprescindibilidade da leitura na formação e, ao mesmo tempo, o conhecimento da realidade dos professores da rede municipal nos mostrava as condições materiais que impeliam as professoras alfabetizadoras a utilizar de um tempo, além da carga horária de trabalho remunerada, para ler os possíveis referenciais de constituição de sua prática pedagógica, caso fosse objetivo tornar-se autônoma intelectualmente.

Com muitas dúvidas sobre o caminho a seguir e com a certeza de que o estudo é base que alimenta a discussão, a reflexão e a problematização e, principalmente, oportuniza o afastar-se do senso comum e pautar-se em resultados de pesquisas acadêmicas, continuamos a inserir, em nossos diálogos, os referenciais em educação matemática. Aos poucos e, em acordo com as condições de vida e trabalho de cada uma, as professoras se aproximaram dos livros e a cada tempo alguém levava algum livro para ler e incluíam em nossos diálogos ideias dos autores que estavam lendo.

É possível ver no vídeo quando o ponto de discussão era a elaboração de perguntas e uma das professoras do segundo ano questiona sobre a metacognição, que ocorre ao colocar a criança para pensar sobre a pergunta e explicitar a sua estratégia de resolução da situação-problema. $\mathrm{Na}$ seção 4.3.1, analisamos a aula dessa professora.

Quadro 16 - Transcrição do diálogo entre a professora e a pesquisadora

\begin{tabular}{|c|c|}
\hline Dimensão visual & Dimensão verbal \\
\hline $\begin{array}{l}\text { A professora do } 2^{\circ} \\
\text { ano mostra as } \\
\text { produções escritas } \\
\text { pelas crianças }\end{array}$ & $\begin{array}{l}\text { Pesquisadora: Conta para nós como foi o trabalho com o livro Economia de } \\
\text { Maria e de que forma vocês fizeram a produção coletiva do texto e das } \\
\text { situações problemas. } \\
\text { Professora I: - o livro foi bastante explorado e a proposta era construir um texto } \\
\text { e desse texto uma situação problema matemática. } \\
\text { - Escrevemos: "Certo dia, duas meninas resolveram passear no shopping. } \\
\text { Mariana, que gostava muito de economizar, comprou apenas um lápis que } \\
\text { custava R } \$ 1,00 \text {, sua irmã Júlia, muito gastadeira, pegou uma bolsa e uma } \\
\text { sombrinha, cada uma custava R } \$ 10,00 \text { e ainda, um ioiô no valor de R } \$ 5,00 \text {. } \\
\text { Chegando ao caixa, cada uma pagou a sua conta." } \\
\text { - Depois colocamos as duas perguntas: } \\
\text { - qual o valor das mercadorias de Júlia? } \\
\text {. E se juntasse as compras de Mariana e Júlia, qual o valor pago? } \\
\text { - Observamos que na situação aparecem os dois objetos respectivamente e a } \\
\text { palavra cada uma com o valor } 10 \text { apenas uma vez e eles conseguiram entender } \\
\text { que a sombrinha era } 10 \text { e a bolsa também era } 10 \text {. } \\
\text { Pesquisadora: Mas, como foi essa escrita...Eles deram ideias... } \\
\text { Professora I: Sim. Eu fui perguntando, eles falando e com a construção no } \\
\text { quadro e fui ajustando. } \\
\text { - interessante, instigante. } \\
\text { - muitos deram a resposta. }\end{array}$ \\
\hline
\end{tabular}




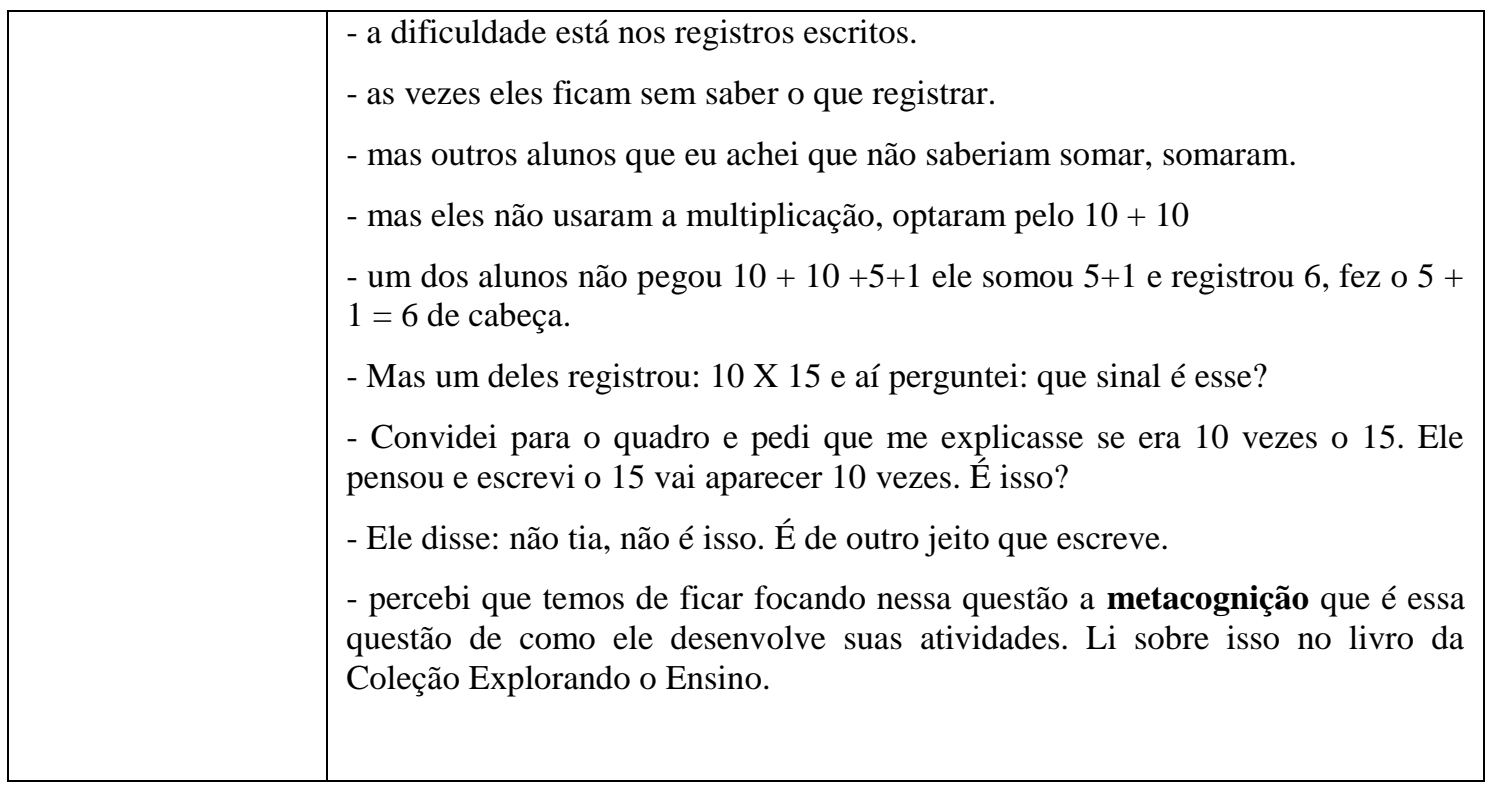

Fonte: Arquivo da pesquisadora, 2015.

O livro ao qual a professora se referiu é o livro Coleção Explorando o Ensino, que contém vários textos de autores da área de educação matemática. Em um dos textos escritos por Carvalho e Lima (2010), os autores falam sobre a explicitação do pensamento pela criança:

Não importa, se em um primeiro momento, ele não consegue justificar sua resposta. Com nossa ajuda, será capaz de, aos poucos, mostrar como pensou para chegar até o resultado. É isso o que se chama de metacognição, a capacidade de pensar sobre o próprio pensamento. (CARVALHO; LIMA, 2010, p. 26)

Um interessante resultado de pesquisa, realizado entre acadêmicos de um Curso de Pedagogia, discutiu a leitura acadêmica na formação docente, as dificuldades e as possibilidades, visto que o interesse por essa questão se tem ampliado. Para os autores Duarte, Pinheiro e Araújo (2012):

Compreender as relações que os docentes foram estabelecendo com livros, ao longo de suas trajetórias de vida e de trabalho, ajuda-nos a perceber que, durante essas trajetórias, muitas pessoas, sobretudo familiares, como o pai, mãe, avó, avô ou mesmo um irmão, contribuíram, de forma marcante, para o gosto pela leitura, enquanto a escola, consoante Kramer (2002, p. 135), via de regra, proporciona uma leitura forçada tida como um dever imposto.

Essa visão escolar da leitura imposta não proporciona, a nosso ver, o resgate da dimensão social e transformadora que a leitura pode oferecer, pois a atividade leitora deve ser vista como um meio de construção da democracia à medida que esta proporcione o desejo de ler, a si mesmo e ao mundo, através da liberdade de comunicação e expressão do leitor (CAVALCANTE Jr., 2005, p. 47). Ou seja, quando a escola nega essa dimensão está negando a própria liberdade de comunicação e expressão, causando, dessa forma, desgosto por essa atividade. Por isso, falar de leitura na formação de professores, na concepção de Kramer (2002), é conhecer histórias de desprazer, imposição, obrigatoriedade, vontade de não ler, oriundas, a nosso ver, da visão escolar e acadêmica da leitura imposta pela escola e pela universidade na época em que estes professores eram alunos/universitários. (DUARTE; PINHEIRO; ARAÚJO, 2012, p. 103) 
Concorda-se com os autores quando afirmam que essa não deveria ser questão de estudo, pois a leitura na formação docente seria algo intrínseco à profissão, mas, nem sempre, em sua trajetória de formação, foi construída uma boa relação com os livros. Gatti (2009), em uma investigação sobre os indicativos do consumo cultural dos estudantes dos cursos de licenciatura, especificamente quanto aos hábitos de leitura, afirma que:

\begin{abstract}
A frequência com que os estudantes leem livros é semelhante entre os estudantes de Pedagogia e demais licenciandos. Em média $28 \%$ deles afirmam ter lido no máximo até dois livros durante o ano, e 35,8\% leram entre três e cinco livros, excluindo os escolares. [...] Mas há ainda um percentual razoável dos que não leem livros além do que lhes é solicitado nos cursos e, entre esses, são mais numerosos os alunos das outras licenciaturas que não a Pedagogia. Quanto aos gêneros, as obras literárias aparecem como as preferidas dos licenciandos de outras áreas quando comparados com os de Pedagogia (46,7\% contra $27 \%$ ), ao passo que os livros técnicos ou de autoajuda parecem interessar mais aos estudantes de Pedagogia (35,95\% contra 24,6\%, tabela A7). Cerca de metade dos alunos afirma ler jornal algumas vezes na semana ou diariamente, mas $35 \%$ deles o fazem raramente. (GATTI, 2009, p.167)
\end{abstract}

Esses dados ainda são reforçados pelos resultados de uma pesquisa realizada por Nunes (2015), em um trabalho de compilação e tratamentos de variáveis socioeconômicas de estudantes de licenciaturas no Brasil, a partir dos microdados do Exame Nacional de Desempenho dos Estudantes do Ministério da Educação - ENADE/MEC, que compreendeu uma amostra de 197.625 alunos, sendo que, destes, 78.088 são de instituições públicas e 119.537 de instituições privadas, a fim de proporcionar um panorama socioeconômico introdutório da amostra trabalhada e verificar a associação entre variáveis tais como curso/renda/cor, curso/sexo/renda, curso/hábitos de estudo, curso/ situação laboral/hábitos de estudo. $\mathrm{O}$ estudo apontou que os estudantes de licenciaturas são oriundos de famílias com baixa renda e pouca tradição escolar, o que os identifica socioeconomicamente com a classe trabalhadora. E, na condição de trabalhadores, eles dedicam menos tempo para a frequência à biblioteca e para os estudos semanais.

É pertinente questionar: se o estudante da licenciatura, futuro profissional professor, durante o curso de formação inicial, não desenvolve hábitos de estudo, o que implica diretamente em realizar leituras, em que tempo e espaço a leitura irá fazer parte das atividades desse professor ao iniciar sua atuação na escola?

Como estamos discutindo a importância da leitura na constituição de conhecimentos necessários para fundamentar a práxis pedagógica, os resultados de Gatti (2009) e Nunes (2015) nos preocupam. E, mesmo cientes dessa realidade, buscamos em Duarte, Pinheiro e Araújo (2012) reforços para defender o prazer de ler e, principalmente, sua necessidade na formação docente:

Refletiremos sobre o prazer de ler, sensação que poderá dividir bons e maus leitores. Não estamos aqui tratando somente da leitura de ficção, possibilitada pelo texto literário, mas também do prazer que é aprender algo através desse ato para tornar-se, assim, uma pessoa 
mais instruída e mais bem informada na vida pessoal e profissional. [...] a leitura possibilita o conhecimento do mundo, o desenvolvimento da criatividade e do senso crítico, o refinamento da percepção e do raciocínio, a imunidade das manipulações oriundas da comunicação pela imagem veiculada pelos meios de comunicação, a facilidade para expressão oral e escrita e a capacidade de monitoramento da compreensão de aspectos gramaticais e de textualidade, da percepção das atitudes e intenções do escritor do texto. (DUARTE; PINHEIRO; ARAÚJO, 2012, p. 103)

Interessa-nos especialmente, neste estudo, ao relacioná-lo ao nosso objeto de pesquisa - a práxis em alfabetização matemática - a leitura como instrumento para a melhoria da prática profissional que, para os autores, é a leitura acadêmica. O que seria, então, a leitura acadêmica? Ela será possível para nós que estamos envolvidos com a rotina das atividades escolares, um dia após o outro, uma aula após a outra, com os planos, com a produção de materiais, com a assistência a comunidade e com a organização da classe? Existe espaço para leitura em nossas condições profissionais e pessoais? Mesmo ciente dessa realidade, acreditamos que sim. Enfim, o que vamos ler no espaço da escola dos anos iniciais? O que, quanto e em que nível de profundidade a professora que atua nos anos iniciais precisa ler? Ou basta a leitura do Manual do professor? Ou seria suficiente uma mais reduzida ainda, apenas a leitura do livro didático? Consideramos esses aspectos fundamentais aos propositores de políticas públicas.

As coordenadoras foram incisivas, mais do que a pesquisadora, e insistiram em programar um Dia D de socialização das leituras, mesmo ao se considerar que nem todas estavam envolvidas com a leitura. A mesma atitude que elas adotavam de "fazer acontecer" os projetos de trabalho com as crianças, foi tomada nessa situação. E, enfim, os títulos já estavam relacionados, foram providenciadas as "bolsas da leitura"; assim, do mesmo modo como as crianças levavam para casa os livros em suas sacolas uma vez por semana, as professoras receberam uma bolsa com um livro, escolhido por elas em uma reunião no mês de agosto. Dessa forma, em acordo com toda a equipe, foi definida a data de 18 de setembro para o que denominamos de I Encontro Literário em Alfabetização Matemática. Nos dias que antecederam o encontro, era possível ouvir muitos comentários: "Nem li todo o livro"; "Li e vi algumas palavras e ideias complexas"; "Estou lendo e as histórias dos professores que estão no livro são as nossas histórias"; "Ainda estou na introdução" (Diário de campo, setembro de 2015. Arquivo da pesquisadora).

Nem cogitamos a possibilidade de mudança de data em respeito a quem avançou na leitura. No dia combinado, realizamos o encontro. A direção da escola modificou os horários, naquela sexta-feira, sem prejuízos para as aulas. Naquele dia pela manhã, não houve coordenação coletiva para que o grupo da manhã retornasse para a escola à tarde. Definimos a garagem da casa da coordenadora, que mora bem próximo à escola, como o local para nosso encontro. Saímos da escola 
às 16 horas e fomos para casa da coordenadora. Ficamos juntos de $16 \mathrm{~h}$ às $18 \mathrm{~h}$ e foi uma das atividades mais produtivas das quais já participamos. Os depoimentos foram muito ricos e evidenciaram as reflexões que ocorreram a partir do que foi lido.

Um modo diferente de trabalhar com a matemática na alfabetização não estaria apenas atrelado às sugestões da pesquisadora, mas a ideias que poderiam ser construídas ao haver uma apropriação dos resultados de pesquisa na área, por meio da ampliação dos estudos. Naquela ocasião, ainda não tínhamos condições favoráveis para realizar estudos contínuos e não houve uma comunicação oficial à Coordenação Pedagógica Geral da Secretaria Municipal de Educação, mas o "fazer acontecer" nos mostrou possibilidades e fortaleceu nosso desejo de reivindicar tempo e espaço para estudar e qualificar-se profissionalmente. $\mathrm{O}$ que implica diretamente na reivindicação de políticas públicas que garantam o tempo de leitura das professoras. Os relatos sobre o que foi lido e o que a leitura ensinou e indicou para a prática em sala de aula foram muito ricos.

Inicialmente apresentamos a fala da professora que realizou a leitura do livro de Nacarato, Mengali e Passos, intitulado A matemática nos anos iniciais do ensino fundamental: tecendo fios do ensinar e do aprender.

Quadro 17 - Transcrição do vídeo ${ }^{36} 18$ de setembro de 2015

\begin{tabular}{|c|c|}
\hline são visual & Di \\
\hline $\begin{array}{l}\text { Professora D } \\
\text { apresenta/aponta para } \\
\text { o livro lido e relata } \\
\text { aos colegas o que leu. }\end{array}$ & $\begin{array}{l}\text { - Eu pensei em trazer um texto [...] uma síntese do livro para entregar uma } \\
\text { cópia para cada um. - Esse livro traz muitas informações importantes } \\
\text { direcionados à formação de professores das séries iniciais. } \\
{[\ldots] \text { aborda de maneira instigante. [...] dá vontade de ir até o fim }} \\
{[\ldots] \text { Trata sobre o ensinar e o aprender matemática nas séries iniciais. }} \\
{[\ldots] \text { de maneira interessante sobre os professores... usam o termo polivalente, }} \\
\text { pois temos que lidar com várias disciplinas... } \\
\text { - Ele traz experiências de professores...experiências em sala de aula } \\
\text { - Fala sobre as crenças que os professores trazem consigo... das experiências } \\
\text { de vida que o professor teve quando estudava... } \\
\text { - Essas experiências de vida são reproduzidas em sala de aula... } \\
\text { - É preciso romper com essas crenças [...] } \\
\text { - Por exemplo, é preciso aprender a lidar com as tecnologias. } \\
\text { - Ver um novo jeito de ensinar ... } \\
\text { - Isso nos leva a repensar o modo de ensinar } \\
\text { - Repensar a prática em sala de aula } \\
\text { - Destaquei: muitas dificuldades } \\
\text { - As autoras reforçam a exigência de romper com as crenças de que a }\end{array}$ \\
\hline
\end{tabular}

\footnotetext{
${ }^{36}$ A transcrição seguiu as orientações de Bauer e Gaskell (2013, p. 351).
} 


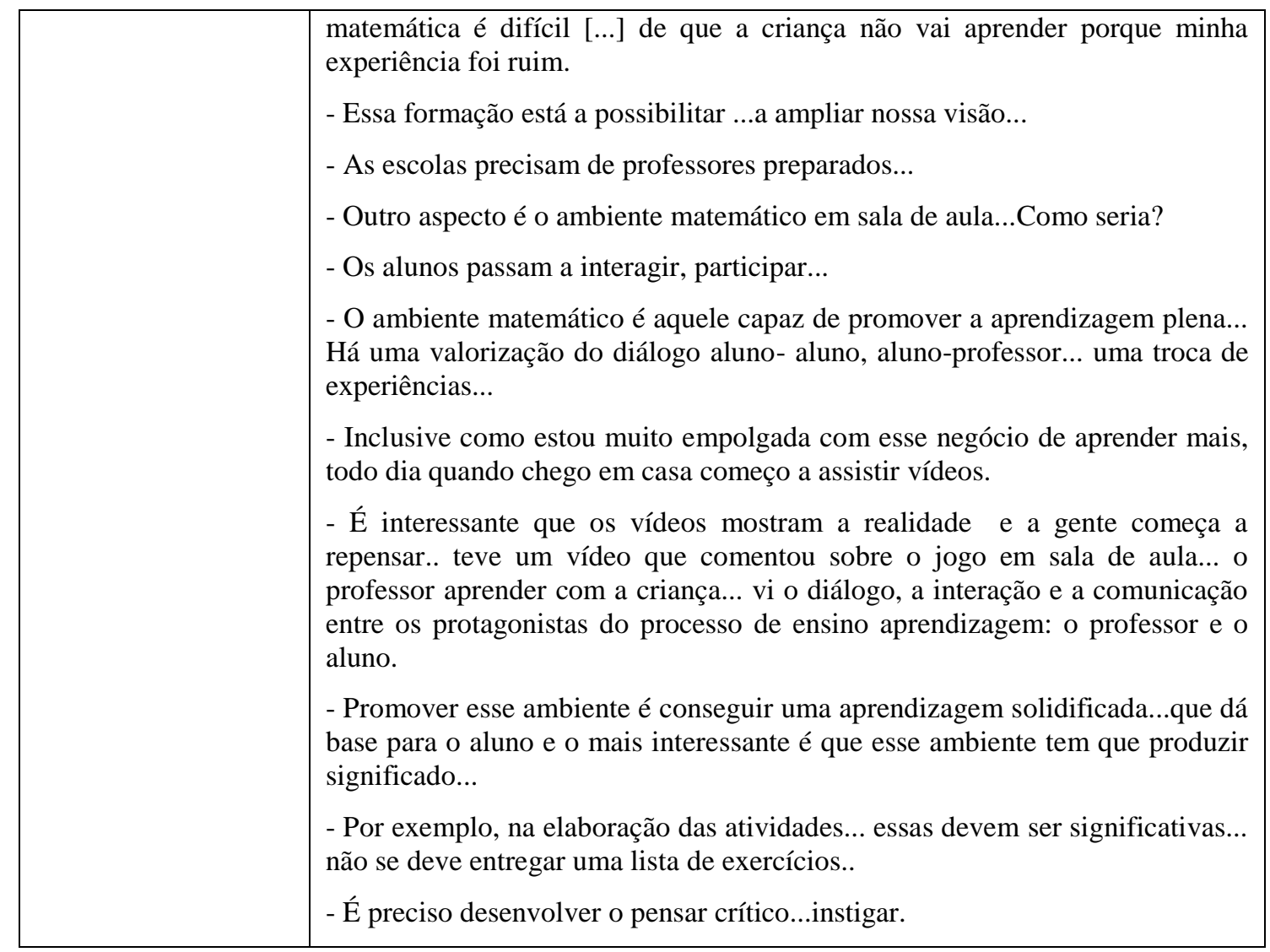

Fonte: Arquivo da pesquisadora, 2015.

Observa-se, entre outros aspectos o desejo da professora em trazer um texto síntese para o grupo, o que não foi possível devido as tantas atividades que sobrecarregam as professoras, além de ter reconhecido no livro as muitas dificuldades que não existem apenas em nosso município. E, ao mesmo tempo, o entusiasmo com a possibilidade de criação de significados para as aulas de matemática, de ambientes de interação, pois em um dos depoimentos dessa professora, durante um dos encontros de formação, ela externou a frustação em dar aulas de matemática apenas porque estavam previstas no plano, mas as atividades na época não tinham nenhum significado e isso a angustiava, por esse motivo contava os minutos para que aquela aula terminasse.

Três professoras escolheram os livros de Smole (2013) da Coleção Mathemoteca. Esses livros trazem um capítulo inicial de discussão teórico-metodológica e, em seguida, descrevem atividades possíveis de serem realizadas em sala de aula. A seguir descrevemos e analisamos a fala das que realizaram a do livro de Stocco e Diniz (2013), que trata do sistema de numeração decimal. Observamos que houve uma preocupação em trazer para o grupo o material sugerido pela autora como, por exemplo, o ábaco. 
Quadro 18 - Transcrição do vídeo: apresentação das professoras

\begin{tabular}{|c|c|}
\hline Dimensão visual & Dimensão verbal \\
\hline $\begin{array}{l}\text { Professoras Jan e } \\
\text { Cris mostram o livro } \\
\text { que leram e colocam } \\
\text { sobre as cadeiras } \\
\text { mostras dos materiais } \\
\text { manipuláveis } \\
\text { descritos pelas } \\
\text { autoras }\end{array}$ & $\begin{array}{l}\text { - As autoras apresentam jogos para fazer em sala; } \\
\text { - Um grande aprendizado foi... Tive a certeza de que não sabia usar o ábaco!!! Por } \\
\text { isso, hoje eu digo que estou inteligente....Eu estou inteligente...estou sabendo usar } \\
\text { o ábaco; } \\
\text { - O livro traz várias sugestões de jogos e atividades bem amarradas: objetivo, } \\
\text { material, quantos jogadores, a que o professor precisa dar atenção, algumas } \\
\text { perguntas que o professor pode fazer; } \\
\text { E uma coisa que me chamou atenção foi a questão da interdisciplinaridade presente } \\
\text { em todas as atividades propostas } \\
\text { E a interpretação, como vimos com Ana, a questão do problema, as mesmas coisas } \\
\text { que a Ana falou para gente de criar perguntas, sobre interpretar o problema... } \\
\text { E ela falou de atividades: problemas; em tiras, montar, discutir cada pergunta, } \\
\text { lançar questões desafiadoras e fazer os registros, como a pró Josi falou que viu na } \\
\text { leitura que fez. } \\
\text { É importante durante o jogo deixar disponível papel e lápis para a criança; }\end{array}$ \\
\hline $\begin{array}{l}\text { Professora Dani } \\
\text { Interrompe e pede } \\
\text { para falar }\end{array}$ & $\begin{array}{l}\text { - assistir em um vídeo que: você traz o problema e que o mais importante não é } \\
\text { uma resposta imediata, não é o registro numérico e sim a estratégia que ele utilizou } \\
\text { para chegar aquela resolução; } \\
\text { - o vídeo mostra claramente que é menos importante a conta; }\end{array}$ \\
\hline $\begin{array}{l}\text { Professora } \\
\text { continua a falar }\end{array}$ & $\begin{array}{l}\text { - A Ana também já falou sobre as estratégias diferentes da esquerda para direita ou } \\
\text { da direita para esquerda; }[\ldots] \\
\text { - Vimos que o papel do professor muda: hora ele dá autonomia, observa como a } \\
\text { criança faz, pensa e analisa; hora ele faz questionamentos, dá para a criança ler e } \\
\text { depois questiona, pergunta se ficou dúvida...explora todas as possibilidades }\end{array}$ \\
\hline $\begin{array}{l}\text { Professora Jan } \\
\text { continua a explorar o } \\
\text { ábaco }\end{array}$ & $\begin{array}{l}\text { - O livro mostra jogos para as } 4 \text { operações. Escolhemos a multiplicação e a } \\
\text { subtração, pois no } 2^{\circ} \text { ano estamos trabalhando com essas duas; } \\
\text { Cris vai fazer, é o mesmo princípio com que fazemos na plataforma } \\
\text { - Ia construir com copos, mas o tempo foi pouco... Peguei esse pronto na escola; }\end{array}$ \\
\hline
\end{tabular}

Fonte: Arquivo da pesquisadora, 2015.

A professora continuou mostrando como usar o ábaco e, mais adiante propôs um jogo e a exploração das fichas escalonadas. Ficou evidente sua alegria em compreender como usar os materiais manipuláveis para trabalhar com as operações. Em sua fala a professora evidenciou a relação entre o que discutimos nos encontros e o que leu no livro. Os destaques foram feitos ao trabalho do professor ao dar autonomia, observar a criança, questionar. Essas possibilidades de organização do trabalho pedagógico foram mais entendidas e apropriadas com a leitura do livro. A proximidade entre o texto lido e a necessidade advinda da prática contribuiu para tornar mais proveitosa a leitura, fato que tornou a apreciação do texto bem mais produtiva. Destacamos o entusiasmo em mostrar partes do livro e a preparação de atividades sugeridas pela autora para 
vivenciar com as colegas. Seria essa uma forte evidencia do processo de formação continuada que estávamos a constituir?

Reiteramos que como professora universitária, formadora de professores e pesquisadora em formação seria incoerente não defender a leitura como uma atividade primordial na formação contínua do professor e no seu desenvolvimento profissional, principalmente para o professor que atua nos anos iniciais do ensino fundamental. O fato dessa etapa ser o início do processo de escolarização para a criança, deveria torná-la um segmento de excelência. Para que isso ocorra, é fundamental que seja prioritário dar aos professores condições de serem leitores.

Em Duarte, Pinheiro e Araújo (2012, p.103), também vimos que o professor poderá, ao ampliar a compreensão do material lido, transferir para sua prática pedagógica o que for pertinente e, dessa forma, ele: “deixa de ser repetidor de conteúdos prontos para tornar-se um profissional mais crítico, capaz de questionar o mundo que o rodeia e também as leituras praticadas ". Nesse aspecto, é possível, então, que a leitura tenha contribuiudo para a construção da identidade profissional das participantes da pesquisa.

Entretanto, os autores chamam a atenção para as dificuldades da leitura do texto acadêmico na formação docente, como a falta de legibilidade do texto, a difícil aquisição de livros, a linguagem excessivamente técnica, a distância e/ou não relação entre teoria e prática e vice-versa, pois as possibilidades da leitura como apropriação da palavra do outro nem sempre ocorrem de forma direta. $\mathrm{O}$ que é lido nem sempre é traduzido para a prática pedagógica. Há que se garantir algumas condições:

\footnotetext{
O professor precisa perceber que a finalidade, o hábito, as habilidades e as estratégias de leitura forem uma constante em sua prática docente, haja vista que a imagem de professorleitor somente é conseguida se a dimensão prática da teoria estabelecer uma relação entre teoria-prática e prática-teoria; uma revalorização do magistério como profissão e uma formação de professores que atrele o discurso acadêmico ao discurso escolar. (DUARTE; PINHEIRO; ARAÚJO, 2012, p. 107)
}

Contudo, mesmo considerando essas dificuldades e limitações, compreendemos a leitura acadêmica como aquela que não se restringe à leitura dentro da academia, nos cursos formais de licenciatura. O texto acadêmico, isto é o texto científico, pode ser lido na escola em que os professores trabalham. Observamos que os livros enviados à escola pelo PNBE não se restringem a manuais didáticos. Foi observado que alguns livros, disponibilizados pela pesquisadora, foram escolhidos pelas professoras e depois devolvidos, devido à complexidade da linguagem e possíveis implicações das diferentes áreas de conhecimento que, na área de educação, se encontram em um 
mesmo texto, exigindo a consulta a outras fontes para compreender a ideia do autor. De toda forma, iniciamos e abrimos esse espaço para a leitura na escola, em meio a tantas adversidades.

Cabe ressaltar o quanto foi importante e diferencial a realização desse encontro, pois mesmo com todos os contratempos, foi um modo de organizar um tempo e um espaço de troca de conhecimentos que teve como fonte estudos sistemáticos registrados por pesquisadores da área. A identificação de orientações teóricas para aperfeiçoar a prática foi algo relevante e, mais ainda, verificou-se que houve a percepção da indissociabilidade entre teoria e prática, pois algumas afirmavam: "Eu fiz e ainda faço dessa forma, pois aprendi assim, mas ao ler sobre isso vejo que o que eu faço estava coerente com o que tinha aprendido... se estudar outras referências a minha prática poderá de verdade ser diferente.[...]. Alguns trechos dos vídeos nos trazem evidências de que essa atividade não se tornou uma sobrecarga improdutiva e, sim, contribuiu com as professoras na direção de conquistar autonomia intelectual.

A seguir, transcrevemos uma discussão animada em que todas falaram sobre o que foi mais significativo no encontro e de que forma têm-se que insistir em realizar esses encontros de leitura:

Edi (Diretora): - não participei diretamente como as meninas que estão em sala de aula, mas na medida do possível estou me envolvendo... destaco a troca de experiências... E livros que tinha no acervo da escola e que nunca tinha visto...esses livros podem estar na mesa da coordenação auxiliando na construção das sequencias didáticas.

Professora Dani (Presidente do Conselho): - temos de garantir que todos participem...a professora $\mathrm{F}$ não está aqui...não participa de quase nada...

Todas: Falou a Presidente do Conselho...rsrsrs...)

Professora Lu: - devemos ter um dia só para isso!!!

Eli (coordenadora): - O calendário não nos permiti isso...modificar os horários... esse encontro riquíssimo...eles (a Secretaria Municipal de Educação) deveriam mudar esse calendário...esbarramos na questão tempo

Professora Ira: - podemos fazer igual ao que fizemos hoje: dispensamos a coordenação da manhã e nos encontramos todos a tarde.

Professora Fran: - anotei tanta coisa... rsrsrs... Mas, na verdade é o que a Ana já vem dizendo sobre a postura do professor, a problematização,...

Pesquisadora: - Vamos nos organizar para outro encontro e vamos trocar os livros;

Os depoimentos das professoras, coordenadoras e diretora nos animaram e nos colocaram o desafio de persistir nessa ideia de "furtar" espaços e tempo de leitura para as professoras dos anos iniciais. Para essa segunda etapa da pesquisa, durante o ano de 2016, previmos essa como uma das principais ações do trabalho de pesquisa na escola. E, além disso, discutir com os representantes da Secretaria Municipal de Educação, formas possíveis de garantir esse espaço institucionalmente. 
Iniciamos o trabalho de pesquisa com o pressuposto de que o espaço - tempo da pesquisa é um legítimo espaço de formação. Uma leitura inspiradora e norteadora de nosso olhar foi Santos (2010) e uma afirmação da autora serviu-nos de sustentação, mesmo nos momentos de maior tensão.

\begin{abstract}
No que diz respeito à formação continuada, o que se espera e se deseja dela é a conjugação de aspectos teórico-práticos, que favoreçam uma sólida formação teórica à reflexão crítica, na valorização da escola como espaço de formação e na valorização dos professores como sujeitos produtores de saberes. Nesse sentido, a formação continuada é considerada como estratégia de desenvolvimento profissional, na medida em que propicia situações de aprendizagem que afetam o processo do aprender a ensinar e o crescimento intelectual dos professores. Inserida nesse quadro a formação continuada denota sua importância como instrumento que concorre para o desenvolvimento pessoal e profissional, bem como favorece o processo de elaboração da prática pedagógica. (SANTOS, 2010, p. 67)
\end{abstract}

Destacam-se nessa afirmação quatro condições fundamentais à formação continuada: (1) conjugação de aspectos teórico-práticos; (2) sólida formação teórica e reflexão crítica (3) valorização da escola como espaço de formação (4) valorização dos professores como sujeitos produtores de saberes. Todas as ações de pesquisa descritas nas seções anteriores contribuíram para a formação das professoras alfabetizadoras. Mas, coerente com essa afirmação, julgamos em meio a dinâmica do movimento de ensinar e aprender diuturnamente e initerruptamente, ser ainda imprescindível, mesmo em condições desfavoráveis ${ }^{37}$, incentivar e disponibilizar material de leitura para o grupo de professoras e de coordenadoras.

\footnotetext{
${ }^{37}$ Mesmo que não tenha sido foco da pesquisa, as condições de trabalho dos professores do município mostraram-se, durante o ano de 2015, desfavoráveis, pois não havia tempo previsto para estudo e ou qualquer outra atividade docente que não fossem as atividades de regência. Em entrevista com um dos membros do Conselho Municipal de Educação esse fato foi confirmado e não justificado.
} 


\section{CONSIDERAÇÕES}

Ao iniciarmos essa parte fundamental de nosso texto, refizemos o caminho que nos levou a realização desta pesquisa. Lembramos que entre todas as experiências vivenciadas como professora de matemática e formadora de professores nos cursos de licenciatura em pedagogia e matemática e outros projetos de formação, as que fazem nos sentir mais produtivas são aquelas em que nos colocamos ao lado das professoras dos anos iniciais do Ensino Fundamental, quer seja nos momentos de estudo, quer seja no acompanhamento das aulas. Sempre é muito intrigante observar e perceber as mudanças que ocorrem no modo como a professora organiza seu trabalho pedagógico, como dialoga com a criança à medida que ela se envolve com os estudos, a forma como aprecia as suas produções e compreende melhor o processo de formação de conceitos matemáticos.

Lembramos que as nossas experiências de formação anteriores a essa pesquisa, nas quais constatamos o desenvolvimento de práxis pedagógicas para ensinar matemática nos anos iniciais do Ensino Fundamental, indicaram possibilidades de promover reflexões, problematizações e mudanças na prática das professoras. Acreditávamos que essas mudanças poderiam ocorrer por meio da parceria entre pesquisadora e professoras em um processo de investigação permanente, em que, a todo o momento, fossem postas em observação e análise as práticas docentes e discentes. Pressupúnhamos que haveria aí a possibilidade de constante reflexão sobre o fazer pedagógico e sua implicação com a aprendizagem.

Interessou-nos a professora polivalente que trabalha nas turmas dos anos iniciais do Ensino Fundamental e é responsável por ensinar conteúdos de várias áreas do conhecimento, entre elas, a matemática. Espera-se que essa professora polivalente, articulada com as diferentes instâncias institucionais, alfabetize a criança em diferentes linguagens, inclusive na linguagem matemática e, mesmo ao considerar o fato da aprendizagem não acontecer estritamente em consequência de ações didático-pedagógicas, somos obrigados a admitir a complexidade do processo de alfabetizar, principalmente no contexto atual de direito da aprendizagem ${ }^{38}$ e temos de enfrentar o desafio e o paradoxo em que nos encontramos de garantir a aprendizagem, mesmo que as professoras e a instituição não possam ter controle absoluto por esse processo que é próprio de cada criança que está aprendendo e em que estão implicados outros elementos que interferem na atuação dessa professora.

\footnotetext{
38 Documento: Elementos Conceituais e Metodológicos para Definição dos Direitos de Aprendizagem e Desenvolvimento do Ciclo de Alfabetização(1 ${ }^{\circ}, 2^{\circ}$ e $3^{\circ}$ anos) do Ensino Fundamental.
} 
Podemos questionar o apoio institucional que essa profissional tem para conseguir desenvolver essa função, assumida no momento em que decide, por circunstâncias diversas, tornarse professora, mais especificamente alfabetizadora. Sabe-se que as políticas públicas voltadas para área de educação, nem sempre favorecem o trabalho inerente às ações profissionais do exercício do magistério com a qualidade prevista nos direitos à aprendizagem. Por exemplo, no espaço escolar, as professoras nem sempre contam com um coordenador pedagógico e um gestor consciente e preocupado com o fazer pedagógico, nem com outros profissionais de apoio, como assistentes sociais e psicopedagogos. Mais do que em qualquer outro momento, coloca-se sobre as professoras uma grande responsabilidade. Repetimos aqui um fato que nos preocupa: em muitas regiões do país, a professora encontra-se sozinha em sala de aula ao decidir e executar sua ação de planejar, ensinar e avaliar.

Como vimos, os resultados das avaliações oficiais ainda mostram um quadro preocupante em alfabetização, principalmente em alfabetização matemática. Ao observar esses dados, o nosso desejo de estar na escola e unir-se as professoras alfabetizadoras em busca de propostas que contribuíssem para o desenvolvimento de novas práxis pedagógicas em alfabetização matemática aumentou, pois vimos a oportunidade de produzir conhecimentos importantes tanto para a professora quanto para a criança, que convive com os conceitos matemáticos em inúmeras atividades cotidianas e terá, ao ingressar formalmente no processo de escolarização, os primeiros contatos com o conhecimento matemático sistematizado.

Nesse contexto, lembramos que a pesquisa que desenvolvemos teve como objetivo analisar um processo de construção de práxis pedagógicas pelas professoras alfabetizadoras quando elas participam, no contexto da escola, de estudos, reflexões, problematizações e discussões sobre alfabetização em matemática, e investigar como essas práxis se integram à formação continuada da professora alfabetizadora. Reiteramos a nossa convicção de que a alfabetização matemática é um trabalho que na escola compete às alfabetizadoras, com apoio da coordenação pedagógica e dos gestores do projeto político pedagógico como um todo.

Isso nos manteve com foco no entendimento de que a práxis pedagógica em alfabetização matemática é uma ação complexa. A professora cria situações de ensino dos conceitos iniciais de matemática. Situações estas que se deveriam transformar-se em situações de aprendizagem para as crianças. Durante toda a pesquisa, acreditamos que a professora alfabetizadora, ao problematizar sua prática, estaria produzindo conhecimentos, que dariam suporte a essa ação intencional, que aproximava a criança da matemática escolar. 
Como discutimos na seção sobre práxis, a atividade teórica mantém estreita relação com a atividade prática e, reiteramos, a partir da dinâmica da pesquisa, que ao exigir o elevado nível de consciência a atividade teórica relaciona-se com a autonomia intelectual. Dizemos isso, a partir do que foi evidenciado em nosso trabalho na escola: cada participante teve oportunidade de constituir, a seu tempo, uma postura autônoma em relação ao que estávamos produzindo juntas. Isso porque transformar a prática em alfabetização matemática foi um objetivo abraçado pelo grupo de alfabetizadoras, que a princípio preocupava-se em "Como aplicar em sala de aula as propostas apresentadas no curso de formação do PNAIC- Matemática - 2014?”. Isso nos leva a refletir os entendimentos que podem ser produzidos pelo modo como são implementadas algumas propostas de curso de formação continuada, que mesmo sendo gestadas como possibilidades de produção de conhecimentos, podem ser vistas pelas professoras como prescrições. Mas, estudar ou avaliar a relação entre o curso de formação continuada do PNAIC e o trabalho da alfabetizadora não foi objetivo desse trabalho.

Movimentamo-nos guiados pelos questionamentos: o que é próprio do trabalho da professora alfabetizadora? Qual seria a melhor forma de pensar sobre a alfabetização? A nossa prática estava realmente voltada para a autonomia intelectual da criança? O que nós sabíamos sobre a criança em processo de alfabetização? Todas as crianças tinham, fora da escola, vivências com situações matemáticas? Essas vivências eram exploradas em sala de aula? O que estávamos propondo às nossas crianças para a ampliação dos conhecimentos já construídos fora da escola e ainda a serem sistematizados no contexto escolar? Quais as condições de trabalho e os recursos materiais que eram garantidos às professoras alfabetizadoras para realizar um trabalho coerente e sintonizado com a aprendizagem da criança?

Entre todos os questionamentos expostos, destacamos que a principal questão que norteou essa pesquisa foi: "De que forma a constituição, no contexto da escola, de um espaço de reflexão, problematização, estudo e discussão sobre a prática em Alfabetização Matemática, contribui para a produção de conhecimentos pelas professoras sobre o ensinar e o aprender, de modo a construir novas práxis pedagógicas, e como essas novas práxis integram-se ao processo de formação continuada em serviço da professora alfabetizadora?"

Propusemos - nos a contribuir com as alfabetizadoras com o mínimo que seria possível, ou seja, auxiliar na ampliação de uma base de conhecimentos para ensinar matemática na alfabetização, conscientes de que essa base integra o conhecimento do conteúdo, o conhecimento didático do conteúdo e o conhecimento curricular (SCHULMAN, 1986). Nesse aspecto, vimos no nosso grupo de professoras que à medida que essa base de conhecimento foi ampliada com as 
leituras, as discussões, os planejamentos, as aulas, as avaliações das aulas e os replanejamentos, configurou-se uma prática pautada em mais segurança e mais tranquilidade, mais leveza e mais coerência.

Acreditávamos que em um espaço de reflexão, problematização, estudo e discussão sobre as práxis em alfabetização matemática, constituído na escola, as professoras superariam dificuldades conceituais e metodológicas que criavam obstáculos a novas aprendizagens e à ressignificação dos conceitos matemáticos e, consequentemente, impediam a criação de planos de trabalho que realmente fossem promotores da aprendizagem da criança. Desse modo, delineamos uma pesquisa, que em muito se aproximou das características de uma pesquisa-formação, na perspectiva de constituir um espaço formativo na escola, em que as profissionais professoras, junto com a pesquisadora, em um trabalho coletivo, produzissem conhecimentos sobre a práxis em alfabetização matemática. Isso ocorreu de modo coerente com a necessária mudança no quadro atual da alfabetização em nosso país. Sabemos que essa mudança não envolve uma única escola e um pequeno grupo de professoras, mas vimos naquele espaço micro uma totalidade que buscou resolver um problema e constituiu-se como grupo na produção de conhecimentos que deram suporte à mudança, num processo dinâmico de pesquisa e formação.

A observação do trabalho na escola foi a base para realizar a pesquisa - formação. Os efeitos dessas ações foram constantemente avaliados e seus resultados relacionaram-se ao contexto: a alfabetização matemática. Destacaram-se a consideração das conjecturas e a criação de situações que provocaram mudanças no modo de ver o conhecimento. No caso da matemática, esperava-se que essa mudança acontecesse, pois a construção de novas práticas pedagógicas exigia a superação de alguns modos equivocados de conceber essa área de conhecimento.

Desse modo, as nossas ações buscaram a relação teoria e prática, o nosso foco foi a prática em sala de aula. De fato, tomar a prática como objeto de análise foi uma ação refletida, problematizada, discutida, que se transformou em reflexão crítica e configurou-se como formação continuada. Contrapor a sua prática a outras práticas, ter consciência de sua ação e fazer autocrítica do trabalho que realiza em sala de aula é algo que foi continuamente realizado pelas professoras. Em nossa pesquisa, identificamos esse movimento: quanto mais conhecimento era produzido ou apropriado pela professora alfabetizadora, mais autonomia era demonstrada, um mais elevado grau de consciência de sua práxis era revelado e uma práxis reflexiva era evidenciada.

Ressalta-se que não foi objetivo desse texto descrever as ações das crianças, isso geraria muitas outras páginas. $\mathrm{O}$ foco da pesquisa esteve no trabalho da professora alfabetizadora, mas as crianças foram, de fato, as maiores beneficiadas com o trabalho realizado, pois as falas, a alegria, o 
entusiasmo em mostrar o tempo todo o que estavam aprendendo foi nosso maior termômetro, um indicador de que as experiências estavam em um caminho coerente.

Nesse processo atentamos juntas a vários aspectos: ao conhecimento dos conceitos, ao planejamento, à avaliação, ao replanejamento, à gestão da sala de aula. Nesse espaço micro - uma escola dos anos iniciais do ensino fundamental, localizada em um bairro periférico de um município no interior do estado - conseguimos com estudos, discussões, problematização da prática, convidar e instigar as professoras a olhar para sua prática, tomá-la como objeto de estudo, perceber a mútua dependência entre teoria e prática, elevar o nível e a consciência de sua ação e sair de uma práxis reiterativa para uma práxis criadora.

Assim foram definidas categorias que após as análises nos levaram a algumas importantes sínteses, que podem servir de referências para outros trabalhos: (i) O conceito de alfabetização norteia a organização do trabalho pedagógico; (ii)A natureza da relação entre a alfabetizadora e o conhecimento matemático interfere na sua forma de definir os objetivos, delimitar os conteúdos e dar significado as aulas de matemática;(iii)A formação continuada em serviço na escola configurase como um espaço de ampliação e aperfeiçoamento da base de conhecimentos e torna possível o caminho de uma práxis reiterativa a uma práxis criadora; (iv) A pesquisa-formação possibilita a formação de parcerias entre escola e universidade; (v) $\mathrm{O}$ trabalho coletivo fortalece o trabalho individual.

Ao considerar essas sínteses destacamos nessa última um fator fundamental na nossa pesquisa: o trabalho coletivo. Era nossa intenção tomar a prática como objeto de análise e deslocarse de uma prática irrefletida e reiterativa para uma prática criadora. Esse movimento, a nosso ver, iria acontecer e fazer sentido para cada uma individualmente, mas seria mais bem compreendido em um engajamento coletivo.

Como podemos verificar, com base nas informações descritas e analisadas, isso de fato ocorreu, o coletivo fortaleceu o individual. A base de conhecimentos, a que já nos referimos aqui, foi mais amplamente construída pela integração do coletivo. Individualmente seria impossível ler o que foi minimamente necessário para dar suporte à mudança que nos propusemos a fazer e que fizemos, mesmo que ainda de modo inicial. Como profissional-professora, além e antes de ser pesquisadora, sempre me senti incomodada com o isolamento que nos é imposto. Decidimos sobre nossa aula e a colocamos em prática na sala com nossos alunos, nos inquietamos, às vezes, ficamos insatisfeitas, repetimos erros, não refletimos coletivamente sobres eles e seguimos individualmente.

Assim, abrir-se à reflexão em um espaço coletivo é possibilitar esse aconchego de ter outros iguais a comungar dos mesmos medos e inseguranças e nos colocarmos juntos em busca de 
caminhos que nos tornem profissionais melhores e mais conscientes de nosso trabalho. Além do mais, entendemos que o coletivo nos faz mais fortes como profissionais pertencentes a uma categoria social de especialistas do ensino, com direitos definidos e com um valor que precisa ser reafirmado numa sociedade que ainda insiste em uma visão equivocada do profissional professor, principalmente da professora dos anos iniciais do ensino fundamental.

A mudança de visão em relação a imprescindibilidade dessa profissional não ocorrerá por decreto oficial. Ela só será possível quando houver uma consciência de classe dos profissionais que, de fato, entendam sua função de ensinar como algo que demanda estudo e que, para acontecer de modo no mínimo adequado, necessita da garantia de condições de trabalho e de renumeração apropriadas. A nosso ver, esse é um aspecto essencial a ser inserido nos projetos de formação continuada em serviço.

O trabalho coletivo, como vivenciamos nesta pesquisa, também contou com a parceria com outros profissionais da escola. Nesse sentido, destacamos de modo especial a ação das coordenadoras, profissionais responsáveis em articular as diversas possibilidades do fazer pedagógico, em criar espaços e condições para ouvir todos os envolvidos na atividade, em promover o debate, o estudo, a formação continuada dos educadores e, a partir disso, realizar e orientar o plano de trabalho pedagógico da escola de modo geral e o da sala de aula especificamente.

Como vimos, sua atuação nas discussões realizadas nos permitiu definir caminhos, principalmente ampliar a ação individual e torná-la parte essencial da ação coletiva. Em nossa pesquisa, esse profissional teve uma atuação mediadora entre a pesquisadora e as professoras, fortaleceu o trabalho da pesquisadora e, ao mesmo tempo, afirmou positivamente o trabalho das professoras. Os nossos primeiros contatos aconteceram com as professoras que nos convidaram à escola, mas ao chegar àquele ambiente, fomos acolhidas pelas coordenadoras que, junto com a gestora, organizavam os tempos de estudos e faziam irradiar nos espaços da escola as decisões definidas coletivamente. Destaca-se, do mesmo modo, o engajamento e o compromisso da gestora que participou ativamente do processo de formação, inclusive preocupou-se em providenciar o possível, dadas as condições da escola, para que o trabalho fluísse.

A pesquisa-formação constituída em um trabalho coletivo nos levou a defender a tese: A constituição de um espaço de problematização, reflexão, estudo e discussão sobre as práxis em Alfabetização Matemática configura-se como formação continuada em serviço das alfabetizadoras. A relação dinâmica entre teoria e prática, neste espaço, dentro da escola, contribui para a produção de conhecimentos sobre a matemática, seu ensino e sua aprendizagem que se traduzem em 
diferenciadas práxis em alfabetização matemática que podem constituir-se em práticas emancipatórias, principalmente quando se consideram os aspectos ideológicos, históricos, culturais e políticos em que uma escola, com seu grupo de trabalho tem suas ações implicadas pelos determinantes da regulação estrutural do sistema de ensino.

Essa tese expressa firmemente o que evidenciaram as informações produzidas ao longo do processo de pesquisa-formação. Vimos que esses conhecimentos não implicaram mudanças apenas na área de matemática, mas na visão da essencialidade da profissional alfabetizadora no contexto histórico, político e social. A dinâmica, que articulou profundamente teoria e prática, configurou um processo de formação continuada e, principalmente, delineou um caminho de conquista de autonomia intelectual que orientou as profissionais atuantes na pesquisa, a ir de uma prática a uma práxis emancipatória. Isso implicou tanto em mudanças no processo formativo quanto no exercício da função de alfabetizar. Ainda vale ressaltar, coerente com o referencial metodológico da pesquisaformação e com os resultados da pesquisa, que acreditamos na estreita relação entre a consciência do seu valor como profissional e a possibilidade de ampliar o entendimento da dimensão histórica, política e social do seu trabalho.

Nesse contexto de pesquisa-formação questionamos se seria possível a professora alfabetizadora constituir uma práxis emancipatória sem autonomia intelectual? Entendemos que se emancipar é tornar-se livre, para tanto, é imprescindível autogovernar-se. No caso das professoras alfabetizadoras, a ação de autogovernar-se esteve diretamente relacionada à busca e à produção de conhecimentos, insistimos que isso ocorre numa progressiva configuração de autonomia intelectual. Inferimos que a constituição de uma práxis emancipatória implica em ter profissionais autônomos.

Resta-nos ainda pensar que a prática pedagógica em matemática tem sido objeto de estudo de muitas pesquisas em educação matemática e, mesmo assim, indagamos: como os resultados desses estudos têm implicado em mudanças na ação do professor? Como alimentam a reflexão e a problematização dos profissionais que atuam na escola? Como elas auxiliam na constituição da práxis? Essas questões permanecem e nos levaram a considerar a possibilidade de dar continuidade a nossa pesquisa. Desse modo, reafirmamos a necessidade de realizar pesquisas em que o pesquisador se coloque em campo, e integre de forma crítica e participativa a comunidade educacional, por meio de sua inserção no cotidiano da escola.

Enfim, as análises e sínteses consequentes da pesquisa - formação nos ajudaram a delimitar o que aprendemos e, ao mesmo tempo, o que ainda precisamos aprender. Neste espaço de considerações, avaliamos as nossas aprendizagens, identificamos lacunas que não foram 
preenchidas, apontamos o que ainda precisa ser mais estudado e apresentamos indicações para a continuidade desse trabalho de pesquisa.

Primeiramente, é sempre necessário estudar sobre aprendizagem, pois o ensinar exige conhecimentos sobre o processo de aprender. A nossa hipótese é que quanto mais sabemos sobre a aprendizagem mais saberemos sobre o ensinar. Em nossa pesquisa, nos dedicamos, por exigência das participantes, a aprendizagem de números e operações, mas nos questionamos se conseguimos realmente compreender a complexidade desses conceitos. Isso é algo a que iremos nos dedicar, pois atentamos ser necessário aprender para si, para compartilhar com o grupo e para construir propostas de ensino.

Do mesmo modo, ficaram indicações sobre a alfabetização estatística. O que de fato é essa alfabetização estatística? Tem-se que estudar muito para dar conta da amplitude desse eixo de aprendizagem que não se restringe a gráficos e tabelas e inclui a probabilidade, a combinatória e o pensamento estatístico e desenvolve raciocínios e habilidades de leitura imprescindíveis no mundo atual.

Nesse sentido, ainda com relação aos eixos de aprendizagem, temos que explorar a percepção das grandezas e as experiências de medição, atividades já previstas desde as primeiras edições dos parâmetros curriculares nacionais da área de matemática, mas que carecem, aqui em nossa região, de mais estudos e vivências de atividades de modo a fazer parte do repertório de tarefas das professoras dos anos iniciais. Outro eixo que precisa ser discutido pelos grupos de estudo de professoras em parceria com pesquisadores em educação matemática é o eixo de geometria, da mesma forma como ocorre em várias regiões do país, como mostram pesquisas já mencionadas por nós.

Reiteramos o que já dissemos no terceiro capítulo: é urgente estudar os conceitos geométricos não apenas por que fazem parte do currículo prescrito, mas por estarem presentes no mundo e desenvolverem habilidades que contribuem na formação da criança. E, ao (re) aprenderem esses conceitos, as professoras mostram-se menos inseguras e constituem uma relação mais saudável com esse saber e, dessa forma, dispõem-se a elaborar propostas de trabalho que realmente irão envolver a criança e promover a aprendizagem.

Além de estudos sobre a aprendizagem, a nosso ver, é essencial a cada tópico de conteúdo matemático estudado pelo grupo - pesquisadora e professoras - refletir sobre o ensino, alimentar a nossa base de conhecimentos pedagógicos que sustenta a nossa prática de ensino e nos dá condições de constituir nossa práxis ao aumentar nossa autonomia intelectual. Ao mesmo tempo em que se (re) aprende os conteúdos matemáticos, se retoma os processos de ensino, por meio dos estudos em 
didática específica, no nosso caso, na área de matemática, e mais precisamente, em educação matemática.

Sabemos que o nosso trabalho, mesmo com todas as provocações que podem ter impactado o trabalho em outras áreas de conhecimento, explorou apenas a matemática escolar, em um contexto micro regional, mas atentamos ao fato de que a alfabetização matemática é integrante da educação científica. Assim, a criança tem direito, em toda e qualquer região brasileira, à uma educação geral que promova o desenvolvimento de habilidades necessárias à sua participação integral na sociedade e isso demanda o investimento na escola por meio da produção e ampliação de conhecimentos. Enquanto pesquisadora e professora de uma instituição de ensino superior, integrante do centro de ciências exatas e tecnologias, consideramos a possibilidade de desenvolver propostas de educação científica.

Temos a intenção de contribuir, a partir deste estudo ora concluído, por meio da institucionalização de projetos de pesquisa e extensão na universidade em que trabalhamos, principalmente para ampliar o debate sobre a alfabetização matemática como parte importante da educação científica das crianças que são cidadãs de direito e poderão, caso tenham um processo de escolarização adequado, ocupar as vagas na universidade. Hipoteticamente as possibilidades seriam bem maiores. Caso isso de fato ocorresse, poderia haver uma mudança da realidade atual em nossa região em que a maior parte das vagas é ocupada por estudantes vindos de outras regiões do próprio estado e de outros estados, pois os adolescentes de nosso município e de municípios vizinhos, como mostram resultados de pesquisa realizados por pesquisadores da universidade ${ }^{39}$, desconhecem a existência de uma instituição de ensino federal em nossa região.

Ao pensarmos no número reduzido de adolescentes que conseguiram alcançar o ensino médio em nossa região, atentamos a um conceito que nos intrigou após o término dessa primeira etapa de pesquisa. Trata-se do conceito de escolarização. O interesse por esse conceito aflorou quando ouvimos queixas das professoras sobre alguns hábitos e atitudes exigidos das crianças que não os apresentavam: "a criança não senta", "não pede a vez para falar", "não sabe prestar atenção", "não sabe ouvir", "não se esforça para buscar respostas e criar soluções”. E nos questionamos em que outros espaços sociais a criança tem que demonstrar esses hábitos e atitudes. Às vezes, parecenos que apenas na escola alguns desses hábitos-conhecimentos-valores são exigidos e devem ser ensinados. O esforço intelectual que a escola exige não nos parece tão presente em outros espaços

\footnotetext{
39 Resultado de pesquisa PIBIC. Título: Expansão da educação Superior na Bahia: Da transição ICADS- UFBA à criação da UFOB: (in) certezas, tensões, desafios e perspectivas. Bolsista: Lucas Emmanuel Silva Teixeira. Orientadora: Cleildes Marques de Santana. Universidade Federal do Oeste da Bahia. Pró-reitoria de pós-graduação, pesquisa e inovação. Coordenadoria de pesquisa.
} 
sociais. E, ao considerar a escola como um espaço de constituição, socialização e ampliação de conhecimentos produzidos pelo homem, vimos o quanto é urgente e necessário ressignificar socialmente o espaço escolar.

Um aspecto que também nos chamou atenção foi o nível socioeconômico das crianças que frequentavam a escola campo de pesquisa. Externava-se uma preocupação em oferecer o melhor àquelas crianças, buscava-se um bom relacionamento com as instituições sociais de apoio como o CRAS, o Conselho Tutelar, o promotor de justiça responsável pela criança. Apesar de esse não ser foco de nossa pesquisa, foi impossível não notar os entraves causados a algumas dinâmicas de trabalho devido à falta de recursos materiais por parte da criança. A escola tinha de prover todo material, inclusive sucata, pois as crianças eram pequenas e às vezes não contavam com ajuda de nenhum adulto.

Existiam diversos tipos de família, o que não foi discutido aqui, mas apenas despertou-nos a atenção, pois as posturas do grupo oscilavam entre o "vamos apostar no potencial da criança" e o "não podemos contar com essa criança, visto pertencer a um grupo social extremamente desfavorecido". O que equilibrava o grupo e fazia todas entrarem num consenso e apostarem cada vez mais no potencial da criança era o fato de que a maioria das professoras, inclusive a gestora e as coordenadoras, pertencia àquela comunidade e residiam naquele bairro. Esse aspecto, não analisado sistematicamente por nós, fez uma grande diferença. Vimos muitas propostas lúdicas, como jogos, dramatização de histórias infantis, declamação de poesias, festas populares, círculos de leitura, serem desenvolvidas pelo grupo, entre alegrias e contratempos, mas com muito desejo de acolher e respeitar a criança daquela comunidade.

Outro fator a considerar é que naquele contexto, a alfabetizadora não contava com recursos materiais que poderiam ser trazidos pela criança. Do mesmo modo, por ausência de uma política séria de apoio institucional por parte da secretaria municipal de educação - não evidenciada durante o período em que realizamos a pesquisa - ela também não contava com os recursos materiais que deveriam existir na escola.

Ainda deve-se ressaltar que além da falta de recursos materiais, a infraestrutura da escola é inadequada, o mobiliário é impróprio para crianças de seis a oito anos. Nesse sentido, poucas escolas do município seriam aprovadas por critérios sérios que definem um prédio adequado a uma instituição de ensino. Além disso, tem-se ainda a inexistência de uma equipe de apoio composta por profissionais especializados em lidar com crianças que apresentam características peculiares devido a pertencerem a um contexto socioeconômico desprovido dos mínimos recursos. 
$\mathrm{E}$, antes de finalizar faz-se necessário esclarecer que as mudanças que ocorreram ao longo do processo de pesquisa podem ser vistas de duas formas: o máximo possível dado o contexto em que nos encontrávamos; o mínimo diante do muito que ainda se tem por fazer. As ideias, as aprendizagens e os conhecimentos produzidos estão em um embrião de possibilidades. Os estudos, as discussões, as reflexões precisam ocorrer de forma contínua. Em um ano e meio não se pode afirmar que as mudanças serão permanentes, pois a tensão entre o possível e o desejável provoca avanços e recuos constantes.

Nesse sentido, é importante atentar-se ao fato de que, mesmo que todas as professoras participassem ao mesmo tempo das atividades de pesquisa, mesmo com um plano de trabalho coletivo, o entendimento e a apropriação dá-se de forma individual, e o momento de traduzir em ações os conhecimentos produzidos é próprio de cada uma. O pesquisador que ingenuamente acreditar que o que foi discutido e acordado no momento coletivo será imediatamente transposto para sala de aula logo verá o quanto está equivocado.

Reafirmamos que os resultados aqui apresentados correspondem a uma primeira etapa de pesquisa referente ao período de fevereiro de 2015 a junho de 2016, em que permanecemos intensivamente na escola, uma vez que estávamos afastadas de nossas atividades na universidade com dedicação exclusiva à pesquisa. A licença para cursar o doutorado finalizou em maio de 2016. Desde então, nos organizamos para institucionalizar um projeto de pesquisa-formação tanto junto à Pró-reitoria de pesquisa quanto junto à Pró-reitoria de extensão e já convidamos os acadêmicos da licenciatura em matemática para envolverem-se em um subprojeto de análise dos resultados da avaliação diagnóstica, de modo que esses licenciandos possam desenvolver um novo olhar sobre as produções das crianças o que pode refletir em suas concepções sobre a aprendizagem e o ensino de matemática.

Considera-se também as possibilidades que existem de trabalho em projetos como o PIBID e a dinamização das horas de ACC - atividades acadêmicas científicas e culturais, em que se pode, como já acontece com outros grupos de pesquisadores em diferentes regiões do país, aproximar os licenciandos das atividades de pesquisa na escola. E, nesse sentido ainda, registramos que existem na região, atuando na rede municipal, estadual e federal de ensino, profissionais interessados em constituir um grupo de pesquisas em Educação Matemática.

Ao mesmo tempo, na escola, as professoras e coordenadoras, mesmo com todos os contratempos, na medida do possível, continuam a organizar grupos de estudo que poderão ser ampliados com o convite que fizemos a professoras alfabetizadoras de duas escolas próximas para integrarem o grupo, uma escola que trabalha com turmas de $1^{\circ}$ ano e uma escola que trabalha com 
turmas de $4^{\circ}$ e $5^{\circ}$ ano. Desse modo, pretende-se que o trabalho continue e amplie-se. Uma possibilidade discutida com o grupo de participantes e já iniciada de modo incipiente é a produção de narrativas. Acordamos com o grupo, a necessária criação de espaços para estudar os referenciais teóricos que, possivelmente em 2017, constituam o suporte a esse trabalho que consideramos como essencialmente formativo. Essa será uma das exigências do grupo junto aos dirigentes da secretaria municipal de educação.

É importante apresentar o nosso agradecimento às professoras que nos permitiram estar em suas salas de aula sem se sentirem intimidadas ou preocupadas com a avaliação de seu trabalho. Pelo contrário, elas mostraram confiança e vontade de se aperfeiçoarem. Enfim, temos a alegria de ter realizado um trabalho similar ao que fizeram tantos outros pesquisadores em educação matemática, de termos tido a oportunidade de dialogar com esses pesquisadores por meio da leitura e de aproximá-los das professoras.

Sentimo-nos felizes em compartilhar a ideia de que uma formação continuada numa perspectiva crítica e emancipatória é permanente, é um processo em que conhecimentos são construídos em busca de soluções para os problemas próprios de nosso trabalho enquanto professoras, principalmente quando se trata do ensino e da aprendizagem na área de matemática. Entendemos que essa formação não ocorre em um momento específico, distante e fora do contexto dinâmico da escola e, sim, em momentos coletivos de problematização da prática, na reflexão, no estudo e na discussão. Esses momentos coletivos podem ser constituídos em parcerias entre professores e pesquisadores numa possível aproximação entre a universidade e a escola. 


\section{REFERÊNCIAS}

ABRANTES, Paulo; SERRAZINA, Lurdes; OLIVEIRA, Isolina. A Matemática na educação básica. Lisboa: ME/DEB. 1999.

AGUERRONDO, I. Formación docente: desafíos de la política educativa. Hacia una política integral para La formación y desarrollo profesional de los maestros de la educación básica. México: Secretaria de Educación Pública, 2006.

ALRO, Helle; SKOVSMOSE, Ole. Diálogo e Aprendizagem em Educação Matemática. Tradução: Orlando de Andrade Figueiredo. Coleção Tendências em Educação Matemática. Belo Horizonte: Autêntica Editora, 2010.

ARTIGUE, Michele, "Ingénierie Didactique". Recherches en Didactique des Mathématiques. Grenoble: La Pensée Sauvage-Éditions, v. 9.3, 281-308, 1988.

BALL, Deborah L. Knowledge and reasoning in mathematical pedagogy: examining what prospective teachers bring to teacher education. 1991. Tese (Doutorado em filosofia). Michigan State University, East Lansing, EUA, 1988. Disponível em: <http://wwwpersonal.umich.edu/ dball/books/DBall_dissertation.pdf $>$ Acesso em janeiro de 2015.

BARBIER, René, A pesquisa-ação. Brasília: LiberLivro, 2007.

BAUER, Martin; GASKELL, George W. (Orgs.). Pesquisa qualitativa com texto imagem e som: um manual prático. Tradução de Pedrinho A. Guareschi. - 11. Ed. Petropólis, RJ: Vozes, 2013.

BERTONI, Nilza Eigenheer. Educação e linguagem matemática II: Numerização. / Brasília: Universidade de Brasília, 2007.

BORBA, Marcelo de Carvalho; ARAÚJO, Jussara de Loiola (Orgs). Pesquisa Qualitativa em Educação Matemática. Belo Horizonte- MG: Autêntica, 2004.

BORBA, Rute; GUIMARÃES, Gilda (Orgs.). Reflexões sobre o ensino de matemática nos anos iniciais de escolarização. Recife: SBEM, 2009( Coleções SBEM, v. 6).

BORDIEU, Pierre Razões Práticas: Sobre a teoria da ação. Campinas: Ed. Papirus, 1996

BRASIL. Secretaria de Educação Fundamental. Parâmetros curriculares nacionais: matemática / Secretaria de Educação Fundamental. - Brasília : MEC/SEF, 1997.

BRASIL. Secretaria de Educação Básica. Elementos conceituais e metodológicos para definição dos direitos de aprendizagem e desenvolvimento do ciclo de alfabetização $\left(1^{\circ}, 2^{\circ}\right.$ e $3^{\circ}$ anos $)$ do ensino fundamental. MEC, Brasília, dezembro/ 2012. 
BRASIL. Secretaria de Educação Básica. Avaliação nacional da alfabetização (ANA): documento básico. - Brasília: Instituto Nacional de Estudos e Pesquisas Educacionais Anísio Teixeira, 2013.

BRASIL. Secretaria de Educação Básica. Pacto Nacional pela Alfabetização na Idade Certa (PNAIC). Ministério da Educação, Diretoria de Apoio à Gestão Educacional. Brasília: MEC, SEB, 2014.

BROCARDO, Joana; SERRAZINA, Lurdes; ROCHA, Isabel. O Sentido do Número: reflexões que entrecruzam teoria e prática. Portugal: Escolar Editora, 2008.

BROUSSEAU, Guy. Os diferentes papéis do professor. In: PARRA, Cecilia; SAIZ, Irma (Orgs.). Didática da matemática: Reflexões Psicopedagógicas. Artes Médicas: Porto Alegre, 1996.

BURIASCO, Regina Luzia Corio de. (Org.) Avaliação e educação matemática. Recife: SBEM, 2008 (Coleção SBEM, vol.4)

CARVALHO, João Bosco Pitombeira; LIMA, Paulo Figueiredo. Escolha e uso do livro didático. In: CARVALHO, João Bosco Pitombeira. Matemática: ensino fundamental. Brasília: Ministério da Educação, Secretaria de Educação Básica, 2010. (Coleção Explorando o Ensino, v. 17).

CHARLOT, Bernard. Relação com o saber, formação de professores e globalização: questões para a educação hoje. Porto Alegre: Artmed, 2005.

CORTESÃO, L. Formas de ensinar, formas de avaliar - Breve análise das práticas correntes de avaliação. In: ABRANTES, P.; ARAÚJO F. (Orgs.). Reorganização Curricular do Ensino

Básico. Avaliação das aprendizagens das concepções às práticas (p.37-42). Lisboa: Departamento da Educação Básica, Ministério da Educação, 2002.

CRUZ, Shirleide Pereira da Silva; NETO, José Batista. A polivalência no contexto da docência nos anos iniciais da escolarização básica: refletindo sobre experiências de pesquisas. Revista Brasileira de Educação, Rio de Janeiro, v. 17, n.50, maio-ago. 2012. Disponível em: <http://www.scielo.br/pdf/rbedu/v17n50/v17n50a08.pdf>. Acesso em 25 mar. 2016.

CURI, Edda. A matemática e os professores dos anos iniciais. São Paulo: Musa Editora, 2005.

CURI, Edda; PIRES, Célia Maria Carolino. Pesquisas sobre a formação do professor que ensina matemática por grupos de pesquisa de instituições paulistanas. Educ. Mat. Pesquisa., São Paulo, v. 10, n. 1, pp. 151-189, 2008.

D’AMBROSIO, Ubiratan. Etnomatemática. São Paulo, SP: Editora Ática, 1990.

DANYLUK, Ocsana. Alfabetização matemática: as primeiras manifestações da escrita infantil. Porto Alegre: Sulina, 2002.

DINIZ, Maria Inez. Os problemas convencionais nos livros didáticos. In: SMOLE, Katia Stocco; DINIZ, Maria Inez. (org.). Ler, escrever e resolver problemas: habilidades básicas para aprender matemática. Porto Alegre: Artmed, 2001. p. 99-102. 
DUARTE, Antonio Lailton Moraes; PINHEIRO, Regina Cláudia; ARAÚJO, Júlio. A leitura acadêmica na formação docente: dificuldades e possibilidades. Rev. de Letras - n. 31, v. (1/2) jan./dez. 2012, 102f. Disponível em:

<http://www.revistadeletras.ufc.br/revista30_arquivos/15_Artigo\%2013_Rev_Letras_31_1_2_2012 3.pdf> Acesso em: 25 mar. 2016.

FERREIRO, Emília, TEBEROSKY, Ana. Psicogênese da língua escrita. Porto Alegre, Artes Médicas, 1984.

FIORENTINI, Dario. Formação de professores de matemática: explorando novos caminhos com outros olhares. Campinas, SP: Mercado de Letras, 2003.

FIORENTINI, Dario. Pesquisar práticas colaborativas ou pesquisar colaborativamente? In: BORBA, Marcelo de Carvalho; ARAÚJO, Jussara de Loiola (Orgs). Pesquisa Qualitativa em Educação Matemática. Belo Horizonte- MG: Autêntica, 2004.

FIORENTINI, Dario; NACARATO, Adair Mendes; PINTO, Renata Anastacio. Saberes da experiência docente em matemática e educação continuada. Quadrante: Revista teórica e de investigação, Lisboa, Portugal, v. 1-2, n. 8, p. 33-60, 1999.

FIORENTINI, Dario; NACARATO Adair Mendes (Orgs). Cultura, formação e desenvolvimento profissional de professores que ensinam matemática: investigando e teorizando a partir da prática. São Paulo: Musa Editora; Campinas, SP: GEPFPM-PRAPEM-FE/UNICAMP, 2005.

FONSECA, Maria da Conceição Ferreira Reis. Alfabetização Matemática. In: BRASIL. Secretaria de Educação Básica. Pacto Nacional pela Alfabetização na Idade Certa. Ministério da Educação, Diretoria de Apoio à Gestão Educacional. Brasília: MEC, SEB, 2014.

FRANCO, Maria Amélia Santoro. Pedagogia da pesquisa-ação. Educação e Pesquisa, São Paulo, v. 31, n. 3, p. 483-502, set./dez. 2005.

GATTI, Bernadete; BARRETO, Elba Siqueira de Sá. Professores do Brasil: impasses e desafios. Brasília: UNESCO, 2009, 294p.

GATTI, Bernadete. A formação de professores no Brasil: características e problemas. Educação e Sociedade, Campinas, v. 31, n. 113, p. 1355-1379, out.-dez. 2010. Disponível em: <http://www.cedes.unicamp.br> Acesso em: 12 fev. 2015.

GATTI, Bernadete. A formação inicial de professores para a educação básica: as licenciaturas. REVISTA USP. São Paulo, n. 100, p. 33-46. Dezembro/Janeiro /Fevereiro 2013-2014. Disponível em: 〈http://www.revistas.usp.br/revusp/article/view/76164/79909> Acesso em: 12 fev. 2015.

GRAMSCI, A. Cadernos do cárcere: os intelectuais, o princípio educativo, jornalismo. Rio de Janeiro: Civilização Brasileira, 2000. v. 2.

HARGREAVES, Andy. Os Professores em Tempos de Mudança. O trabalho e a cultura dos professores na idade pós-moderna. Lisboa: Mc Graw-Hill, 2001. 
HYPOLITO, Álvaro M. Trabalho Docente e Profissionalização: Sonho Prometido ou sonho Negado? In: HYPOLITO, Álvaro M. Trabalho docente, classe social e relações de gênero. Campinas: Papirus, 1997.

KAMII, C. A criança e o número. Campinas: Papirus, 1990.

KUENZER, Acácia Z.; CALDAS, Andrea. Trabalho docente: comprometimento e desistência. In: FIDALGO, Fernando; OLIVEIRA, Maria Auxiliadora M.; FIDALGO, Nara Luciene Rocha (Orgs): A Intensificação do Trabalho Docente: tecnologias e produtividades. Campinas, SP: Papirus, 2009.

LERNER, Délia; SADOVSKY, Patrícia. O sistema de numeração: um problema didático. In: PARRA, C. SAIZ, I. Didática da Matemática: reflexões psicopedagógicas. Porto Alegre, RS: Artmed, 1996.

LIMA, Márcio Antônio Cardoso; MARTINS, Pura Lúcia Oliver. Pesquisa-ação: possibilidade para a prática problematizadora com o ensino. Diálogo Educ., Curitiba, v. 6, n.19, p.51-63, set./dez. 2006.

LONGAREZI, Andrea Maturano, SILVA, Jorge Luiz. Pesquisa- formação: um olhar para sua constituição conceitual e política. Revista Contrapontos - Eletrônica, Vol. 13 - n. 3 - p. 214-225 / set-dez 2013.

MAGINA, Sandra; CAMPOS, Tânia; NUNES, Terezinha; GITIRANA, Verônica. Repensando Adição e Subtração: contribuições da Teoria dos Campos Conceituais. 3 ed. São Paulo: PROEM, 2008.

MANDARINO, Mônica Cerbella Freire. Que conteúdos da matemática escolar professores dos anos iniciais do ensino fundamental priorizam? In: GUIMARÃES, Gilda; BORBA, Rute. Reflexões sobre o ensino de Matemática nos anos iniciais de escolarização. Biblioteca do Educador Matemático, Coleção SBEM, volume 6. Recife: Sociedade Brasileira de Educação Matemática, 2009. 138p.

MANRIQUE, Ana Lúcia; ANDRÉ, Marli E. D. A. Relações com saberes na formação de professores. In: NACARATO, Adair Mendes; PAIVA, Maria Auxiliadora Vilela. A formação do professor que ensina matemática: perspectivas e pesquisas. Belo Horizonte: Autêntica, 2006.

MARTINS, Pura Lúcia Oliver. As formas e práticas de interação entre professores e alunos. In: VEIGA, Ilma Passos de Alencastro (Org.). Lições de didática. Campinas, SP: Papirus, 2006.

MOLINA, Rinaldo. A pesquisa-ação/investigação-ação no Brasil: mapeamento da produção e os indicadores internos da pesquisa-ação colaborativa. 2007. Tese (Doutorado em Educação). São Paulo: FEUSP, 2007. Disponível em:

<www.teses.usp.br/teses/disponiveis/48/...25072007.../TeseRinaldo.pdf> Acesso em: jan. 2015.

MUNIZ, Cristiano Alberto. Políticas públicas e formação inicial e continuada de professores que ensinam matemática. GT-19: Educação Matemática. In: 31 a REUNIÃO ANUAL DA ANPEd, 30, Caxambu, MG. Anais ... ANPEd, 2008. Disponível em:

<http://31reuniao.anped.org.br/trab_encomendados.htm>. 10 jan. 2015. 
MUNIZ, Cristiano Alberto. Diversidade dos conceitos das operações e suas implicações nas resoluções de classes de situações. In: GUIMARÃES, Gilda; BORBA, Rute. Reflexões sobre o ensino de Matemática nos anos iniciais de escolarização. Biblioteca do Educador Matemático, Coleção SBEM, volume 6. Recife: Sociedade Brasileira de Educação Matemática, 2009a. 138p.

MUNIZ, Cristiano Alberto. A produção de notações matemáticas e seu significado. In: FÁVERO, Maria Helena; CUNHA, Célio da. (Org.). Psicologia do Conhecimento: o diálogo entre as ciências e a cidadania. $1^{a}$ ed. Brasília: Unesco e UnB, 2009b, v. 1, p. 115-143.

MUNIZ, Cristiano Alberto. Papéis do brincar e do jogar na Alfabetização Matemática. In: BRASIL. Secretaria de Educação Básica. Pacto Nacional pela Alfabetização na Idade Certa. Ministério da Educação, Diretoria de Apoio à Gestão Educacional. Brasília: MEC, SEB, 2014.

MUNIZ, Cristiano Alberto; BATISTA Carmyra Oliveira; SILVA Erondina Barbosa da. Módulo IV: Matemática e Cultura: Decimais, Medidas e Sistema Monetário. - Brasília: Universidade de Brasília, 2008. 109 p.

NACARATO, Adair Mendes. A Educação Continuada sob a Perspectiva da PesquisaAção: currículo em ação de um grupo de professores ao aprender ensinando geometria. 2000. 323p. Tese (Doutorado em Educação: Educação Matemática) — FE, Unicamp, Campinas (SP). Orientador: Dario Fiorentini

NACARATO, Adair Mendes (Org.). Práticas docentes em Educação Matemática nos anos iniciais do ensino fundamental.1. ed., Curitiba: Appris, 2013.

NACARATO, Adair Mendes; MENGALI, Brenda Leme da Silva; PASSOS, Carmem Lúcia Brancaglion. A matemática nos anos iniciais do ensino fundamental: tecendo fios do ensinar e do aprender. Belo Horizonte: Autêntica, 2014. (Tendências em Educação Matemática).

NACARATO, Adair Mendes; PAIVA, Maria Auxiliadora Vilela. A formação do professor que ensina matemática: perspectivas e pesquisas. Belo Horizonte: Autêntica, 2006.

NACARATO, Adair Mendes; PASSOS, Cármen Lucia Brancaglion. A geometria nas séries iniciais: uma análise sob a perspectiva da prática pedagógica e da formação de professores. São Carlos: EdUFSCar, 2003. 151 p.

NACARATO, Adair Mendes; PASSOS, Cármen Lúcia Brancaglion; GRANDO, Regina Célia. Organização do trabalho pedagógico para a alfabetização matemática. In: BRASIL. Secretaria de Educação Básica. Pacto Nacional pela Alfabetização na Idade Certa. Ministério da Educação, Diretoria de Apoio à Gestão Educacional. Brasília: MEC, SEB, 2014.

NUNES, Daniel Freitas. Quem quer ser professor no Brasil: uma análise a partir de variáveis socioeconômicas de estudantes de licenciatura. 2015. Dissertação (Mestrado em educação). Universidade de Brasília, 2015. 126p.

OLIVEIRA, Dalila Andrade; VIEIRA, Lívia Fraga. Condição de trabalho docente: uma análise a partir de sete estados brasileiros. . In: Trabalho na Educação Básica: a condição docente em sete estados brasileiros. Belo Horizonte: Fino Traço, 2012. p. 153-190. 
OLIVEIRA, Gaya Marinho; OLIVEIRA, Ana Teresa C.C. A matemática na formação inicial de professores dos anos iniciais: Reflexões a partir de uma análise de teses e dissertações defendidas entre 2005 e 2010 no Brasil. Anais do XI ENEM,2013. Disponível em:

<http://www.sbem.esquiro.kinghost.net/anais/XIENEM> Acesso em: mai. 2015.

PAIS, Luís Carlos. Didática da matemática: uma análise da influência francesa. Coleção:

Tendências em Educação Matemática. Belo Horizonte: Autêntica, 2001.

PANIZZA, Mabel. Ensinar matemática na educação infantil e nas séries iniciais: análise e propostas. Tradução Antônio Feltrin. Porto Alegre: Artmed: 2006.

PAVANELLO, Regina Maria. A análise de episódios de ensino e a formação do professor reflexivo. In: GUIMARÃES, Gilda; BORBA, Rute. Reflexões sobre o ensino de Matemática nos anos iniciais de escolarização. Biblioteca do Educador Matemático, Coleção SBEM, volume 6. Recife: Sociedade Brasileira de Educação Matemática, 2009. 138p.

PAVANELLO, Regina Maria. Geometria e construção de conceitos aritméticos: investigando algumas inter-relações. In: 23 ${ }^{a}$ REUNIÃO DA ANPEd. Anais... Caxambu- MG, 2000. Disponível em:

<http://23reuniao.anped.org.br/textos/1906p.PDF>. Acesso em 12 mar. 2015.

PERRELLI Maria Aparecida de Souza, REBOLO Flavinês, TEIXEIRA, Leny Rodrigues Martins, NOGUEIRA Eliane Greice Davanço. Percursos de um grupo de pesquisa-formação: tensões e (re)construções. R. bras. Est. pedag., Brasília, v. 94, n. 236, p. 275-298, jan./abr. 2013.

PIMENTA, Sema Garrido; LIMA, Maria Socorro Lucena. Estágio e docência. São Paulo: Cortez, 2004. (Coleção docência em formação. Série saberes pedagógicos)

PIMENTEL, Cláudia. A criança e a cultura. In: CARVALHO, Mercedes; BAIRRAL, Marcelo Almeida (Orgs.). Matemática e Educação Infantil: Investigações e possibilidades de práticas pedagógicas. Petrópolis, RJ: Vozes, 2012.

PIRES, C. M. Carolino. Currículos de matemática: da organização linear à ideia de rede. São Paulo: FTD, 2000.

PIROLA, Nelson Antonio; MORAES, Mara Sueli Simão. O Pró-Letramento e a formação continuada de professores que ensinam matemática no primeiro ciclo do ensino fundamental. Texto produzido atendendo à solicitação do Grupo de Trabalho de Educação Matemática da ANPEd, 2008.

PONTE, João Pedro da. O desenvolvimento profissional do professor de matemática. Repositório da Universidade de Lisboa. Educação Matemática 31, 1994. Disponível em: http://repositorio.ul.pt/bitstream/10451/4474/1/94\%20Ponte\%20EM31\%20pp09-12_20.pdf. Acesso em 24 nov. 2014.

PONTE, João Pedro. Perspectivas de desenvolvimento profissional de professores de Matemática. In: PONTE, João Pedro et al (Eds.). Desenvolvimento profissional de professores de Matemática: Que formação? (p. 193-211). Lisboa: SEM-SPCE. 1995. 
PONTE, J. P. O conhecimento profissional do professor de matemática. Educação, Sociedade e Culturas, 9, 189-195, 1998.

PONTE, J. P.; FONSECA, H.; BRUNHEIRA, L. Actividades de investigação na aula de Matemática. Veritati - Revista da UCSal, Universidade Católica do Salvador, 4, 57-73. 2004.

PORTO NASCIMENTO, Ana Maria. A pesquisa como instrumento de mediação num ambiente de aprendizagem matemática: aprende a criança, aprende a professora e aprende a pesquisadora. 2002. Dissertação (Mestrado). Faculdade de Educação. Universidade de Brasília, 2002.

RABELO, Márcia Helena Marques; CURI, Edda. Sistema de numeração decimal: alguns indicativos da pesquisa para o ensino. In: CURI, Edda. Programa Observatório da Educação: pesquisas desenvolvidas e contribuições para o ensino de Matemática nos anos iniciais. São Paulo: Terracota Editora, 2014.

RANGEL, Ana Cristina Souza. Educação matemática e a construção do número pela criança: uma experiência em diferentes contextos sócio-econômicos. Porto Alegre: Artes Médicas, 1992.

REIS, Maria Elídia Teixeira; FIORENTINI, Dario. Desenvolvimento profissional em saberes e práticas num curso de licenciatura em Matemática para professores em serviço. In: $30^{\mathrm{a}}$ REUNIÃO ANUAL DA ANPEd, 30, Caxambu, MG. Anais... Rio de Janeiro: ANPEd, 2007. v. 1. p. 1-17.

ROEGIERS, Xavier. Uma pedagogia da integração. Trad. Carolina Huang. $2^{\mathrm{a}}$ ed. Porto Alegre: Artmed, 2004.

ROLDÃO, Maria do Céu. Função docente: natureza e construção do conhecimento profissional. Universidade do Minho, Centro de Estudos da Criança. Revista Brasileira de Educação v. 12 n. 34 jan./abr. 2007. Disponível em: 〈http://www.scielo.br/pdf/rbedu/v12n34/a08v1234.pdf > Acesso em: 12 jun. 2014.

SANTOS, Edlamar Oliveira dos Santos. A formação continuada na rede municipal de ensino do Recife: concepções e práticas de uma política em construção. 2010. Tese (Doutorado) - Centro de Educação. Universidade Federal de Pernambuco, 2010.

SAVIANNI, Demerval. O pensamento pedagógico brasileiro: da aspiração à ciência à ciência sob suspeição. Educação e Filosofia, v.21, n. 42p. 2007. Disponível em:

<http://www.labes.fe.ufrj/arquivos/Savianni_2007.pdf.> Acesso em: 23 mai. 2014.

SAVIANNI, Demerval. Formação de professores no Brasil: dilemas e perspectivas. Revista Poíesis Pedagógica - V.9, N.1 jan./jun. 2011a; p.07-19.

SERRAZINA, Maria de Lurdes. Reflexão, conhecimento e práticas lectivas em matemática num contexto de reforma curricular no $1^{\circ}$ ciclo. Revista Quadrante, Lisboa, v. 8, 1999.

SERRAZINA, Maria de Lurdes. O professor como investigador: leitura crítica de investigações em Educação Matemática. Refletir e investigar sobre a prática profissional. Organizado por GTI da APM. Lisboa, APM, 2001. 
SERRAZINA, L. Preâmbulo. In: CASTRO, J.; RODRIGUES, M. Sentido de número e organização de dados - Textos de apoio para educadores de infância (p. 9). Lisboa: Ministério da Educação. 2008.

SERRAZINA, Maria de Lurdes Marquês. Conhecimento matemático para ensinar: papel da planificação e da reflexão na formação de professores. Revista Eletrônica de Educação. São Carlos, SP: UFSCar, v. 6, no. 1, p.266-283, mai. 2012. Disponível em:

<http://www.reveduc.ufscar.br>. Acesso em: 18 mar. 2015

SCHULMAN, L. Those who understand: knowledge growth in teaching. Educational Research, n. 15 (2), pp. 4-14, 1986.

SILVA, Edileuza Fernandes da. As práticas pedagógicas de professoras da educação básica: entre a imitação e a criação. In: VEIGA, Ilma Passos de Alencastro; SILVA, Edileuza Fernandes da (Orgs.). A escola mudou. Que mude a formação de professores. Campinas, SP: Papirus, 2010.

SILVA, Kátia Augusta Curado Pinheiro Cordeiro da. Professores com formação stricto sensu e o desenvolvimento da pesquisa na educação básica da rede pública de Goiânia: realidade, entraves e possibilidades. 2008. 292f. Tese (Doutorado em Educação) - Faculdade de Educação, Universidade Federal de Goiás, Goiânia, 2008. p. 90-13.

SILVA, Kátia Augusta Curado Pinheiro Cordeiro da. A formação de professores na perspectiva crítico-emancipadora. Revista Linhas Críticas, v.17, n. 32. Brasília: Universidade de Brasília/FE. 2011.

SKOVSMOSE, Ole. Cenários de investigação. Bolema - Boletim de Educação Matemática, Rio Claro/SP, n. 14, 2000.

SKOVSMOSE, Ole. Educação Matemática crítica: A questão da democracia. Campinas, SP: Papirus, 2001. $160 \mathrm{p}$.

SMOLE, Kátia C. S. Textos em Matemática: Por que não? In: SMOLE, Kátia Stocco e DINIZ, Maria Ignez (Organizadoras). Ler, escrever e resolver problemas. Porto Alegre: Artmed, 2001.

SMOLE, K.S.; DINIZ, M.I. (Org.) Ler, escrever e resolver problemas: habilidades básicas para aprender matemática. Porto Alegre: Artmed, 2001. 204p.

SPINILLO Alina Galvão. Uso e função dos números em situações do cotidiano.In: BRASIL. Secretaria de Educação Básica. Pacto Nacional pela Alfabetização na Idade Certa. Ministério da Educação, Diretoria de Apoio à Gestão Educacional. Brasília: MEC, SEB, 2014.

THIOLLENT, M. Metodologia da pesquisa-ação. São Paulo: Cortez. 2000.

THOMPSON, Alba Gonzales. A relação entre concepções de Matemática e de ensino de Matemática de professores na prática pedagógica. Tradução de Gilberto F.A. de Melo e Tadeu Oliver Gonçalves. Zetetiké. Campinas: CEMPEM, v. 5, n. 8, p. 11- 44, jul./dez. 1997.

TOLEDO, Marília; TOLDEO, Mario. Teoria e prática de matemática: como dois e dois. São Paulo: FTD, 2009. 
VÁZQUEZ, A. S. Filosofia da Práxis. Rio de Janeiro: Paz e Terra, 4ª ed. 1990.

VEIGA, Ilma. A prática pedagógica do professor de didática. Campinas, SP: Papirus, 1992.

VEIGA, Ilma Passos de Alencastro (Org.). Lições de didática. Campinas, SP: Papirus, 2006.

VEIGA, Ilma; AMARAL, Ana Lúcia. Formação de Professores: políticas e debates. $3^{\mathrm{a}}$ ed. Campinas: SP, Papirus, 2006 ( $1^{\text {a }}$ Ed. 2002). Disponível em: < http://books.google.com.br/ > Acesso em: 18 mar. 2016.

VEIGA, I. P. A.; MOREIRA, A. M. A.; SOUSA, José Vieira de; BORGES, L.F.F. ; RESENDE, L. M. G. DE ; PINHEIRO, M. E. Docentes Universitários Aposentados: ativos ou inativos? 1. ed. Araraquara: Junqueira \& Marin, 2007. 92 p.

VEIGA, Ilma Passos de Alencastro; SILVA, Edileuza Fernandes (Orgs.). A escola mudou. Que mude a formação de professores. Campinas, SP: Papirus, 2010.

VEIGA, Ilma Passos Alencastro; VIANA, Cleide Maria Quevedo Quixadá. Formação de Professores: um campo de possibilidades inovadoras. In: VEIGA, Ilma Passos Alencastro; SILVA, Edileusa Fernandes. A escola mudou: que mude a formação de professores. Campinas, SP: Papirus, 2010. - (Coleção Magistério: Formação e Trabalho Pedagógico)

VERGNAUD, G. La théorie de champs conceptuels. Recherches en Didactique de Mathématiques, 1990, vol 10, n².3, pp. 133-170. Pensée Sauvage: Grenoble, França.

VIANA, Carlos Roberto. Relações entre o sistema de escrita alfabética e o sistema de numeração decimal: algumas reflexões. In: BRASIL, Ministério da Educação. Secretaria de Educação Básica, Diretoria de Apoio à Gestão Educacional. Pacto Nacional pela Alfabetização na Idade Certa. Caderno 3- PNAIC - Brasília: MEC, SEB, 2014.

VYGOTSKY, L.V. Pensamento e Linguagem, São Paulo, Ed. Martins Fontes, 2000.

WOLMAN, Susana; QUARANTA, Maria Emília. Discussões nas aulas de matemática: o que, para que e como se discute. In: PANIZZA, Mabel. Ensinar matemática na educação infantil e nas séries iniciais: análise e propostas. Tradução Antônio Feltrin. Porto Alegre: Artmed: 2006.

ZUNINO, Délia Lerner. A matemática na escola: aqui e agora. 2 ed. Porto Alegre: Artes Médicas, 1995. 


\section{APÊNDICE - Termo de consentimento livre e esclarecido}

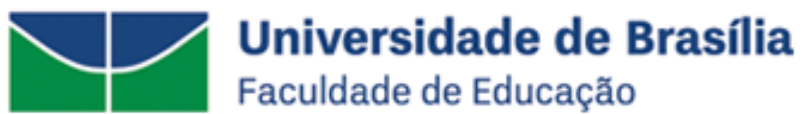

Esse Termo de Consentimento Livre e Esclarecido busca atender ao disposto na Resolução n.12/2009 do Programa de Pós-Graduação da Faculdade de Educação da Universidade de Brasília.

\section{TERMO DE CONSENTIMENTO LIVRE E ESCLARECIDO}

Convidamos o (a) Sr (a) para participar da Pesquisa PRÁXIS PEDAGÓGICA EM ALFABETIZAÇÃO MATEMÁTICA, sob a responsabilidade da pesquisadora ANA MARIA PORTO NASCIMENTO, a qual pretende analisar um processo de construção de novas práticas em alfabetização matemática. Sua participação é voluntária e se dará por meio de: (1) participação nos grupos de discussão que se realizarão nos horários destinados a coordenação, respeitando o cronograma proposto pela Coordenação da Escola Campo de Pesquisa; e (2) desenvolvimento de aulas de matemática. As discussões do grupo e as aulas serão gravadas em áudio e vídeo. É importante esclarecer que os participantes não correrão riscos. Se você aceitar participar, estará contribuindo para a constituição de grupos de pesquisa em alfabetização matemática inseridos na dinâmica do contexto escolar dos anos iniciais do Ensino Fundamental, especificamente nos Ciclos de Alfabetização. Se depois de consentir em sua participação o Sr (a) desistir de continuar participando, tem o direito e a liberdade de retirar seu consentimento em qualquer fase da pesquisa, seja antes ou depois da coleta dos dados, independente do motivo e sem nenhum prejuízo a sua pessoa. O (a) Sr (a) não terá nenhuma despesa e também não receberá nenhuma remuneração. Os resultados da pesquisa serão analisados e publicados, sua identidade será divulgada com o seu consentimento. Para qualquer outra informação, o (a) Sr (a) poderá entrar em contato com o pesquisador no endereço Universidade Federal do Oeste da Bahia, pelo telefone (77) (3614 -3500), ou poderá entrar em contato com o Programa de Pós-graduação da Faculdade de Educação da Universidade de Brasília telefone (61) 3107-6243 ou (61) 3107-6244.

Consentimento Pós-Informação

Autorizo a utilização, para fins estritamente científicos, das informações obtidas na pesquisa. Concordo, como participante da pesquisa, que minha identificação seja divulgada. A identificação dos alunos participantes da pesquisa será mantida em sigilo. Estou ciente de que a minha participação é voluntária e de que posso, em qualquer momento do processo, retirar meu consentimento. Declaro ter recebido informações suficientes sobre os objetivos e demais aspectos da pesquisa, tendo sido esclarecida em relação às minhas dúvidas. Afirmo, ainda, que recebi uma cópia desse documento.

Assinatura do participante:

Data:

Assinatura da Pesquisadora: 